Florida International University FIU Digital Commons

\title{
Resource Nationalism and Energy Integration in Latin America: The Paradox of Populism
}

Brian Hollingsworth

bholl002@fiu.edu

DOI: $10.25148 /$ etd.FIDC006843

Follow this and additional works at: https://digitalcommons.fiu.edu/etd

Part of the Comparative Politics Commons, Economic Policy Commons, Energy Policy

Commons, Growth and Development Commons, International Economics Commons, International

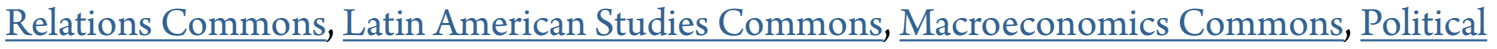

Economy Commons, and the Regional Economics Commons

\section{Recommended Citation}

Hollingsworth, Brian, "Resource Nationalism and Energy Integration in Latin America: The Paradox of Populism" (2018). FIU

Electronic Theses and Dissertations. 3790.

https://digitalcommons.fiu.edu/etd/3790 


\section{FLORIDA INTERNATIONAL UNIVERSITY}

Miami, Florida

RESOURCE NATIONALISM AND ENERGY INTEGRATION IN LATIN AMERICA:

THE PARADOX OF POPULISM

A dissertation submitted in partial fulfillment of the

requirements for the degree of

DOCTOR OF PHILOSOPHY

in

INTERNATIONAL RELATIONS

by

Brian Edward Hollingsworth 
To: Dean John F. Stack, Jr.

Steven J. Green School of International and Public Affairs

This dissertation, written by Brian Edward Hollingsworth, and entitled Resource Nationalism and Energy Integration in Latin America: The Paradox of Populism, having been approved in respect to style and intellectual content, is referred to you for judgement.

We have read this dissertation and recommend that it be approved.

$\begin{array}{r}\text { Maria Willumsen } \\ \hline \text { Frank Mora } \\ \hline \text { Harry Gould } \\ \hline \text { Eduardo Gamarra, Major Professor }\end{array}$

Date of Defense: June 20, 2018

The dissertation of Brian Edward Hollingsworth is approved.

Dean John F. Stack, Jr. Steven J. Green School of International and Public Affairs

Andres G. Gil Vice President for Research and Economic Development and Dean of the University Graduate School

Florida International University, 2018 
(C) Copyright 2018 by Brian Edward Hollingsworth All rights reserved. 


\title{
ABSTRACT OF THE DISSERTATION \\ RESOURCE NATIONALISM AND ENERGY \\ INTEGRATION IN LATIN AMERICA: THE PARADOX OF POPULISM
}

by

\author{
Brian Edward Hollingsworth \\ Florida International University, 2018 \\ Miami, Florida \\ Professor Eduardo Gamarra, Major Professor
}

This dissertation examines the relationship between resource nationalism and energy integration, and uses Bolivia and Brazil as a test case. This study asks if resource nationalism affects energy integration. The findings nest within more expansive questions on international political economy and export-driven models of development. Why do populist regimes, historically operating under an economic nationalist cum protectionist paradigm, simultaneously pursue policies of economic integration? What is the relationship between resource nationalists and open markets, especially in the hydrocarbons sector? What is the relationship between populists, who are typically resource nationalists, and their decision to choose policies of energy integration?

The most common responses to the above are that resource nationalists pursue protectionist policies in the hydrocarbon sector. This dissertation demonstrates that once in power, resource nationalists do not always pursue protectionist policies in the hydrocarbon sector, but instead rely on market forces. Another common response is that populists pursue policies of resource nationalism in the hydrocarbon sector. This dissertation demonstrates that populists do not always pursue policies of resource nationalism in the hydrocarbon sector, but instead choose policies of integration. Policies 
of integration are compelled by market forces, and at times ironically provide the foundation for resource nationalism to later flourish.

This dissertation develops a case-study of Bolivia and Brazil to assess the relationship between resource nationalism and energy integration. The case is selected based on each country having energy resources or derivative products for exploitation and use, an energy trade relationship between the countries, the presence of government-run natural resource firms in each country, and a specific period where resource nationalism is present. Bolivia and Brazil are important for this study because of their proximity, particularly where the supply of natural gas is concerned. Proximity is of great importance as natural gas infrastructure is concomitant with energy integration, particularly supply. 


\section{TABLE OF CONTENTS}

CHAPTER

PAGE

I. CHAPTER ONE..................................................

Introduction, Research Purpose, and Research Question.................. 1

Literature Review...............................................11

Methodology ...................................................... 43

Chapter Outline.................................................5

Appendix.........................................................55

Works Cited...................................................... 57

II. CHAPTER TWO ................................................65

Bolivia: Chapter Abstract.......................................65

Bolivia: Current Scenario..........................................65

Bolivia: Markets, Boom-Bust Cycle, and Populism...................69

Bolivia's Natural Gas Relationship with Brazil: A Synopsis............116

Works Cited....................................................117

III. CHAPTER THREE............................................ 120

Brazil: Chapter Abstract...........................................120

Brazil: Current Scenario..........................................120

Brazil: Populism, Petroleum, and Neoliberalism.....................122

Brazil's Natural Gas Relationship with Bolivia: A Synopsis.............155

Works Cited................................................156

IV. CHAPTER FOUR ............................................... 158

Introduction ................................................... 158

Why Natural Gas is Important..................................161

Background on National Oil Companies, Petroleum, and their Relationships in Bolivia and Brazil..........................166

Bolivia........................................................ 174

Brazil.......................................................... 188

Toward the Future................................................. 197

Major Conclusions of Chapter Four..............................202

Works Cited.......................................................204

V. CHAPTER FIVE: ANALYSIS AND ASSESSMENT ...................207

General Statement...............................................207

Applicability, Final Observations, and Beyond.....................220 


\section{LIST OF GRAPHS}

GRAPH

PAGE

Graph 1: Bolivia Trade Balance (\% GDP) .......................................66

Graph 2: Bolivia Foreign Exchange and GDP....................................67

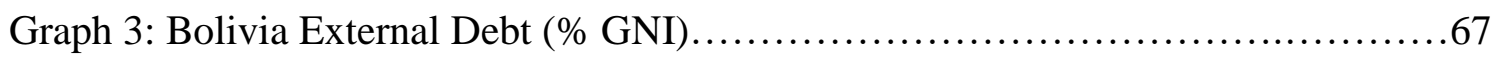

Graph 4: Bolivia Economic Growth (Rate Change as \% of Real GDP.................68

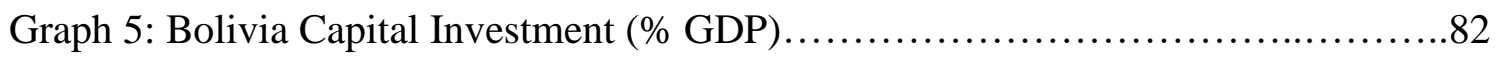

Graph 6: Bolivia Economic Growth (Rate Change as \% Real GDP)....................82

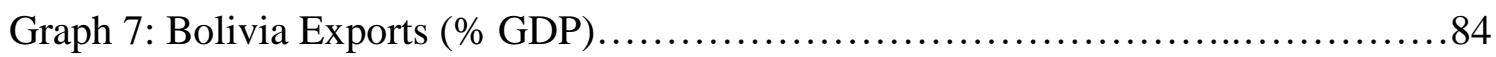

Graph 8: Bolivia Commodities as \% of Exports (1962-1969)...........................84

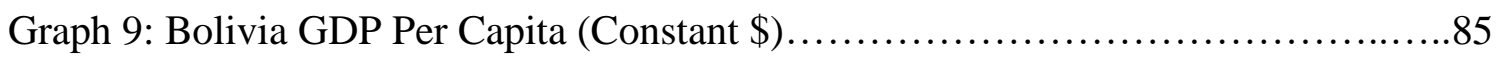

Graph 10: Bolivia Commodities as \% of Exports (1969-1979)_........................87

Graph 11: Bolivia Economic Growth (Rate Change as \% Real GDP)..................91

Graph 12: Bolivia GDP Per Capita (Constant \$) ...................................91

Graph 13: Bolivia Inflation (\% Change in CPI) ................................92

Graph 14: Bolivia Foreign Direct Investment (\% GDP)............................93

Graph 15: Bolivia Capital Investment (\% GDP) ...................................95

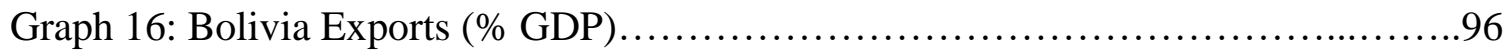

Graph 17: Bolivia GDP (\% Share Agriculture) ....................................... 97

Graph 18: Bolivia Manufacturing Value Added (\$ Billions)..........................97

Graph 19: Bolivia Economic Growth (Rate Change as \% Real GDP)....................101

Graph 20: Bolivia Foreign Direct Investment (\% GDP).............................102

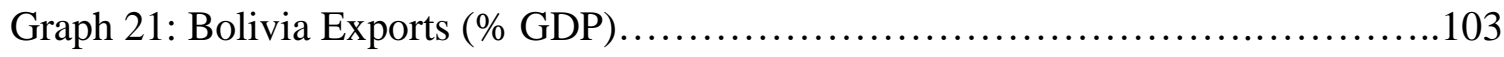

Graph 22: Bolivia GDP Per Capita (Constant \$) .....................................104

Graph 23: Bolivia Inflation (\% Change in CPI) ................................106

Graph 24: Bolivia Inflation (\% Change in CPI) .................................. 106

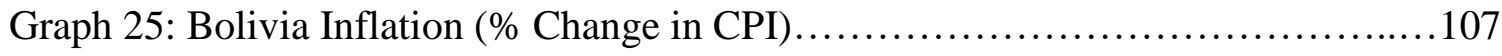

Graph 26: Bolivia Commodities as \% of Exports (1980-1993).........................108 
Graph 27: Bolivia Economic Growth (Rate Change as \% Real GDP) ...................110

Graph 28: Bolivia GDP Per Capita (Constant \$) ..................................111

Graph 29: Bolivia Capital Investment (\% GDP) .................................113

Graph 30: Bolivia Commodities as \% of Exports (1993-2015).........................114

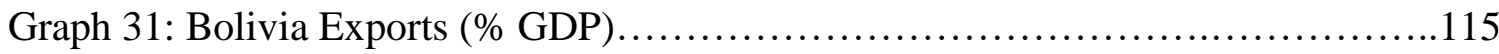

Graph 32: Bolivia Foreign Direct Investment (\% GDP) ..........................115

Graph 33: Brazil Exports (Commodities and Products)..............................127

Graph 34: Brazil Exports (Commodities and Products)...............................130

Graph 35: Brazil Inflation (\% Change in CPI) ................................... 141

Graph 36: Brazil Inflation (\% Change in CPI) ..................................

Graph 37: Brazil Foreign Direct Investment (\% GDP)............................146

Graph 38: Brazil Exports (Commodities and Products)...............................147

Graph 39: Brazil GDP (Share of Agriculture)................................... 148

Graph 40: Brazil Manufacturing Value Added (\$ Billions) ..........................148

Graph 41: Brazil Foreign Direct Investment (\% GDP) ............................ 152

Graph 42: Natural Gas Consumption in Latin America (Bcm) 1965-2013 ...............173

Graph 43: Bolivia \% of Electricity from Source..................................... 175

Graph 44: Bolivia Trade with Brazil (\$ Million)....................................177

Graph 45: Percent of Bolivia's Natural Gas to Customers..............................177

Graph 46: Bolivia GDP (Million \$) ........................................... 178

Graph 47: Bolivia Natural Gas \& Crude Exports to Brazil.............................179

Graph 48: Yearly Mean Average (\$MMBtu) for HH Natural Gas Spot Prices..........181

Graph 49: Natural Gas Prices for Bolivia, Brazil and Henry Hub Benchmark ...............182

Graph 50: Natural Gas Spot Price, Total Bolivia Revenues, and Bolivia Percentage

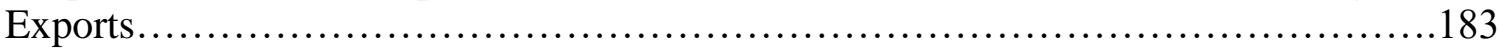

Graph 51: Bolivia Natural Gas Reserves, Production, and Price.........................184

Graph 52: Bolivia Natural Gas Production and Price..................................185

Graph 53: Brazil Percentage of Electricity from Source................................189

Graph 54: Brazil Imports of Petroleum Gases.........................................190

Graph 55: Brazil Natural Gas Consumption (Bcm).................................193 
Graph 56: Brazil Natural Gas Reserves, Production, and Price...................... 194

Graph 57: Brazil Natural Gas Production and Price.............................. 195 


\section{CHAPTER ONE}

\section{Introduction, Research Purpose, and Research Question}

Energy is the single most important factor that enhances quality of life as well as economic development. Life without energy is a miserable existence in many parts of the world as simple tasks require a large portion of human labor to gather fuel for heating, cooking, or even to provide dim amounts of unstable light. Gathering naturally available resources for conversion into energy can be exhausting as well as dangerous for the over one billion people on the planet without regular access to what the industrialized world takes for granted. Reliable access to energy provides the foundation for economic development at the most basic level as well as that for industry to develop and thrive. Regarding security, energy is as important to the functioning of the global economy as it is surrounded by conflict and political unrest. For these reasons energy and its integration require examination. The literature on energy mostly concerns oil and natural gas, but some recent writings have expanded investigations to include other commodified natural resources. Natural gas as an energy source and its role in the integration between Bolivia and Brazil are central to this dissertation. Among available energy sources, natural gas is exceptional for all modern economies and offers important benefits when compared to reducing pollution associated with the burning of wood, coal, or dung in the developing world as well as that associated with processed energy sources derived from oil in the industrial world.

This dissertation concerns resource nationalism, energy integration, and national resource companies. Resource nationalism is a global phenomenon and includes developed and emerging economies alike. This dissertation examines the relationship 
between resource nationalism and energy integration, and uses Bolivia and Brazil as a test case. Essentially, does resource nationalism affect energy integration?

Few deep studies into the phenomenon of resource nationalism exist. This dissertation helps fill that gap. Despite a history of nationalism and state involvement in the energy sector, the idea of energy integration has been a globally important and potentially transformative objective during at least the last several decades. This objective clearly exists within Latin America as energy resources in this region are not uniformly distributed. At the time of writing, asymmetries loom large as new resource deposits are discovered. Argued benefits of energy integration are significant and have potential strategic, economic, and development ramifications. Latin America will continue to play a role in energy policies of nations, both regionally and extrahemispherically.

\section{$\underline{\text { Research Purpose }}$}

Countries with extensive natural resources pursue arrangements with countries lacking such endowments, and the search for energy resources drives development patterns. The central thrust of the nationalist argument is that foreign investment in the natural resources sector will inevitably affect a country's national security and its longterm development goals - namely because profits from sales of such resources accumulate abroad. Resource nationalism has surfaced in several settings but has been particularly visible in Latin America since the early part of the twentieth century, especially since the discovery of large petroleum deposits in Venezuela. Populist 
governments often implement resource nationalist policies in the hydrocarbon sector. Why do populist, protectionist governments then seek integration agreements? In the cases of Bolivia and Brazil, populism and resource nationalism figure prominently in development patterns surrounding these hydrocarbon-dependent economies.

Latin America is important for study as the region provides immense energy resources for export at a time when the world's countries increasingly require supplies of energy. Across Latin America from the late-1800s to the 1930s primary commodities exports drove development. After the Great Depression and through the 1960s, Latin America underwent Import Substitution Industrialization (ISI) in attempts to reduce foreign dependency. ${ }^{1}$ From the 1970s through the 1980s the oil and interest rate shocks, followed immediately by a debt crisis, curtailed development goals. During the 1990s, the region experienced a neoliberal push via the Washington Consensus. ${ }^{2}$ The 2000s through the present have witnessed a return to a commodity-driven export model fueled by oil, natural gas, and mining. The effectiveness of this development model is frustrated by government rent-seeking and weak institutions (Laserna 2010).

This dissertation explores the above in the context of Bolivia and Brazil and examines their development patterns and integration into the world economy, particularly

\footnotetext{
${ }^{1}$ Import Substitution Industrialization (ISI) is a development strategy that focuses on promoting or replacing previously imported goods with those produced domestically, and mainly pursued from the 1930s through the 1960s in several countries in Latin America, as well as some countries in Africa and Asia. The aim of ISI was to substitute imported manufactured goods from Europe and North America by developing a domestic manufacturing capability, and was a means for the economies of Latin American countries to break out of the international division of labor which relegated them to producers of raw materials.

${ }^{2}$ The Washington Consensus was a body of ideas which were implemented to aid Latin America in its economic development and integration into the world economy; these policies were not a prescription, but a list that was considered desirable in Latin America at the time. The Washington Consensus has been strongly criticized for its monolithic approach to repairing perceived and dissimilar economic realities (Kuczynski and Williamson 2003; Panizza 2009).
} 
under nationalist, populist regimes. After a mostly twentieth-century historical discussion of each country, the dissertation centers on development patterns and energy market integration from the mid-1980s through 2016. For both countries, the middle1980s is an important time in the periodization of this study. In 1985, Bolivia implemented its New Economic Policy amid increasing democratization, and Brazil ended its dictatorship. These separate issues are inextricably linked and directly relevant to this study.

Conclusions from this dissertation generate and increase attention to energy market policies in Latin America and contribute to literature on Bolivia, Brazil, and other countries in the region. Additionally, the study may provide generalizable results for the energy sector and for regions outside Latin America, particularly concerning populism and economic integration.

\section{$\underline{\text { Research Question }}$}

This dissertation concerns resource nationalism, energy integration, and national resource companies in Latin America. The literature on energy itself is vast, that of resource nationalism is growing, and until recently there was limited writing on energy integration in Latin America. The relationship between resource nationalism and energy integration in Latin America drives this dissertation.

In the past century, nearly every country possessing vast natural resources has faced some sort of nationalism aimed at preventing foreign investment or development, especially in the hydrocarbons sector. This economic nationalism is often resource- 
centric in its scope and argues mainly that natural resources represent a strategic security sector that should remain in the hands of the state. Moreover, in twentieth-century Latin America, military officers often seized power in their attempts to reform socio-economic development through authoritarian rule. During this same period, numerous countries in the region began to reconsider the role between the state and the people, to include the responsibility of the former regarding the social condition of the latter. The idea that the state had a social responsibility toward the people regarding capital, workers' economic rights, and the protection of the family differed greatly from the Anglo-American concept of state-society relations (Wiarda 2001). This dissertation investigates resource nationalism and energy market integration, and asks why populist regimes, historically operating under an economic nationalist cum protectionist paradigm, simultaneously pursue policies of economic integration.

This study will define and compare two concepts, resource nationalism and energy integration, and test the hypothesis to determine if there is a relationship between each. In this dissertation resource nationalism (Independent Variable) - defined as the notion that control over a nation's economy should be in the hands of nationals, that nationals should have preference over foreigners in reaping the benefits of business and economic opportunities in the country, and nationalist resentment of foreign investment arguably has the potential to frustrate the benefits of energy integration. Energy integration (Dependent Variable) forms part of a larger, multidimensional process, which includes coordination, cooperation, and convergence among countries and touches economic, political, social, and environmental themes. It is not solely focused on oil, but includes resources such as natural gas and secondary products like electricity and 
gasoline. In this dissertation, energy integration is defined as exports of natural gas from Bolivia to Brazil, whereby an increase of natural gas imports into Brazil is a key indicator of integration. The research question seeks to determine the relationship between resource nationalism and energy integration. Key in this dissertation is to understand and explain why populist or economic nationalists pursue such market integration.

Concerning the concept of integration, unlike oil, natural gas neither exists in an internationally integrated market, nor is it fungible across the entire supply chain. Simply put, across the oil market one may convert their position into dollars, then into another currency as desired (Downey 2009, 323). Oil markets are so well developed and liquid that there are ample opportunities to buy and sell oil on the spot market. Natural gas markets are less developed than those for oil, and largely dependent on regional pricing. Development of gas markets requires long-term planning from upstream research and development to downstream marketing and retail.

Gas market development can take decades of planning, requiring first and foremost the presence of natural gas and the concomitant intent to develop the reserves. Prior to breaking any ground, there must be a geopolitical arrangement which will encourage transactions. Once geopolitical arrangements are established, there is a need to develop a legal framework to support the long-term contract (Take-or-Pay or Ship-orPay contracts are uniquely crafted for each natural gas customer). ${ }^{3}$ Beyond the contract, there is supporting physical infrastructure, hiring of firms and labor to construct the pipeline itself, marketing, and the development of the retail market in the country on the

\footnotetext{
${ }^{3}$ Take or Pay (ToP) is defined as a firm commitment to purchase a minimum quantity of gas downstream. Ship-or-Pay (SoP) is a firm commitment to provide a minimum quantity downstream. For a detailed description of ToP contracts in the Bolivia-Brazil case, see Medinacelli (2017)
} 
receiving end of natural gas exports. The above are economic multipliers resulting from natural gas projects. ${ }^{4}$ Economies of scale spread the set-up costs over the life of the contract. The natural gas relationship between Bolivia and Brazil offers opportunities for both countries to benefit from economies of scale; since 2000, the Bolivia-Brazil pipeline at the heart of this dissertation has passed through Corumbá, Brazil. Corumbá, Brazil is located at a junction of air routes, as well as has rail connections leading to Santa Cruz, Bolivia and São Paulo, Brazil.

Bolivia and Brazil, through economic integration in the form of natural gas trade, are able to advance mutually beneficial economic goals. Essentially, as economies integrate, barriers decrease. The fewer trade barriers, the more economic and political coordination there is between countries. Advantages to economic integration include a possible reduction in the cost of trade, improved employment opportunities as trade liberalization can lead to market expansion, and political cooperation may improve because of stronger economic ties. Disadvantages to economic integration exist, and may include potential erosion of national sovereignty, regionalism, or trade diversion. The nature of the relationship between Bolivia and Brazil is likely not one where integration will result in a loss of sovereignty for either country.

Naturally, divergent levels of economic strength, sophistication, or competitiveness may cause contention over how an integration project may progress. Brazil's large market provides membership rents to Bolivia by absorbing an increased percentage of the latter's natural gas exports. The pipeline agreement with Brazil is

\footnotetext{
${ }^{4}$ In economics, a multiplier shows the effect of change in national investment on the amount of national income. For example, an increase in the total amount of investment in an economy will result in subsequent increases in expenditures. The process may continue indefinitely.
} 
crucial in the development of Bolivia's gas reserves; and, Brazil benefits from Bolivian gas. In the case of the Bolivia-Brazil natural gas pipeline, advantages for both countries far outweigh their disadvantages.

Measurement of economic integration often involves a combination of economic indicators, to include trade in goods and services, labor migration, and international capital flows. In the case of Bolivia and Brazil, a major step towards integration derives from creating a successful agreement despite divergent regulatory frameworks. Additionally, the participation of private firms promotes economic development. For example, private business participation comes in the form of niche firms that provide pipeline technology and management consulting support in the natural gas sector. Perhaps most importantly, the Bolivia-Brazil pipeline provides the foundation for the creation of an integrated natural gas market in the Southern Cone, as it has the potential to link gas-rich countries such as Argentina and Bolivia to major centers of demand such as Brazil, Chile, and Uruguay. In the case of this dissertation, exports of natural gas from Bolivia to Brazil are the most reliable and measurable indicator.

This long-term approach to natural gas development is the crux of market integration, particularly between the two countries central to the study: Bolivia and Brazil. In this dissertation, natural gas exports are the only reliable and quantifiable indicator for measuring energy market integration between Bolivia and Brazil. Certainly, the larger and multidimensional process of integration touches upon additional themes; however, their quantification is elusive. Moreover, as later demonstrated, natural gas exports from Bolivia to Brazil generate the lion's share of Bolivia's national income. It is plausible that the loss of such a large percentage of income will damage any economy. 
For this reason, the pipeline between Bolivia and Brazil presents a unique opportunity to measure integration. Over time, as the adaption of liquefied natural gas (LNG) becomes more widespread, the potential for a single integrated market for natural gas may develop; however, this is unlikely in the short-term, and outside the scope of this dissertation.

This study asks two questions. First, what is the relationship between resource nationalists and open markets, especially in the hydrocarbons sector? The most common explanation is that resource nationalists pursue protectionist policies in the hydrocarbon sector. However, once in power resource nationalists do not always pursue protectionist policies in the hydrocarbon sector, but instead rely on market forces. Second, what is the relationship between populists, who are typically resource nationalists, and their decision to choose policies of energy integration? In this second instance populists pursue policies of resource nationalism in the hydrocarbon sector. The alternate hypothesis here is that once in power, populists do not pursue policies of resource nationalism in the hydrocarbon sector, but instead choose policies of integration because of market forces. The integration of the energy sector, particularly involving natural gas, between Bolivia and Brazil is where this dissertation tests these hypotheses.

The selection of Bolivia and Brazil as a case-study is multi-faceted. Conceptually, there is not as much robust energy research involving Latin America compared to other regions; and, within academia, Bolivia and Brazil are underinvestigated. Pragmatically, this research may encourage a better understanding of the benefits of market integration with Brazil as some of the assumed detractors implicit in resource nationalism are better understood. Brazil as regional hegemon, its ability to 
project power, and its proximity to markets in the Americas all offer integration prospects.

Brazil's need for natural gas may be satisfied through Bolivian imports. This presents the opportunity to determine the effects of Bolivian resource nationalism on what would appear to be an ideal economic match concerning energy integration and cooperation between the two countries. The proximity of Bolivia and Brazil is of paramount importance as natural gas infrastructure is necessary for energy integration. Natural gas is central in the relationship between Brazil and Bolivia, and the fundamental economic principles which apply to other natural resource projects also govern natural gas. Aside from the centrality of natural gas to the Bolivia-Brazil relationship, this commodity is experiencing a revolution which has implications involving the entire production, distribution, and consumption cycle. Joint technological advances in hydraulic fracturing and horizontal drilling coupled with the emergence of a nascent internationally integrated market for natural gas demands attention.

There are four testable hypotheses for this research. First, an increase in resource nationalism (RN) will result in an increase in energy integration (EI). Second, a decrease in $\mathrm{RN}$ will result in a decrease in EI. Third, an increase in $\mathrm{RN}$ will result in a decrease in EI. Last, a decrease in RN will result in an increase in EI. This dissertation considers these hypotheses, and the most likely prediction is that market forces drive integration and compel decision-making regardless of nationalist sentiment.

Historically, many countries in Latin America have placed their natural resources under state control and have established both legal and constitutional barriers to foreign involvement in domestic energy production. Such barriers are a potential frustration to 
the development of energy resources and the idea of integration. The Bolivia-Brazil case is selected based on the following variables: energy resources for exploitation, government-run natural resource firms, and energy import/export relations with other countries in Latin America.

The historical record on oil, natural gas, and associated firms, whether independent or national, is inconsistent. The oil and gas industries have a veneer of perceived impropriety, government involvement in the economy is often seen with suspicion, businesses are not always transparent, and much information that could be of benefit to this study remains proprietary. This study's conclusions will contribute to the energy and academic fields, and will open further avenues of research as new information becomes available. Furthermore, this study will generate or increase attention to regional energy integration in Latin America and contribute to the literature on Bolivia, Brazil, and possibly other countries in the hemisphere. Finally, the case study may provide generalizable results applicable to other regions, particularly Africa, where many countries institutionally lag Latin America.

\section{Literature Review}

This literature review explains the context in which natural resources may be sources of conflict, the concept of national sovereignty over resources, and the explanation of resource nationalism relative to energy integration in Latin America. The literature is broken down by relevant theme. Within each section the literature is mostly 
arranged chronologically to demonstrate its evolution across time. Engagement with the literature is intertwined throughout.

\section{Conflicts over Resources and Energy Security at the Geopolitical Level:}

It is presently impossible to restructure our modern and high-energy civilization based on non-fossil (renewable) fuels. The eventual transition from dependence on fossil fuels is inevitable, however, and it is important to realize such a transition will be much more of a challenge than initially or commonly accepted. Wealthy countries may be able to make the transition more easily than poorer ones, and such a transition is desirable for two central reasons. First, the long-term effects of climate change and related concerns over declining availability of low-cost and high-quality fuels. Second, there are concerns over the alleged imminence of global peak-oil extraction, followed by a rapid decline in global oil production (Smil 2010). If the argument of global peak-oil is credible, the inevitable end of cheap energy sources and their associated ease of acquisition could lead to geopolitical conflict. However, some consider the "peak-oil" argument a fallacy as it faced challenges even before present popular consumption (Adelman 1972, 538).

Michael Klare has written extensively on increased competition for limited natural resources. Klare's arguments have been consistent since his 1981 work on how the United States of America (U.S.) supplies weapons to the world and to oppressive regimes. After establishing this early framework, Klare's writing evolves and he couches his arguments into the larger literature on conflicts over dwindling resources. Klare maintains the general theme that the U.S. is a key actor in Latin America, and its influence in the region cannot be underestimated. Later writing (2001) argues resource 
wars will become the distinctive feature of the global security environment for several reasons. These reasons include economic drivers, increased demand for commodities, potential shortages of key resources, instability in areas that hold resources, and the proliferation of disputes over resource ownership. Market forces and technological progress mitigate some problems, while side-effects of globalization exacerbate others.

Klare (2004) argues the U.S. is converting into a global oil-protection service. He then juxtaposes the increased U.S. imports of oil and reduced production of oil within the U.S. as drivers of future conflict over the resource because of U.S. dependency on oil. Written before the recent dual revolution in hydraulic fracturing and horizontal drilling, Klare should not be considered remiss in his analysis. Nevertheless, such dependency arguably weakens the U.S. Weaknesses stem from vulnerability to supply disruptions (whether accidental or intentional), a transfer of economic resources from the U.S. to foreign suppliers, potential for entanglements in overseas wars, and increased likelihood for violently hostile political or religious factions to resent a U.S. presence in their region.

By securitizing oil, the U.S. makes energy a fundamental component of its national security. ${ }^{5}$ This is a premise to which much of U.S. foreign and military policy has applied since the Second World War. Klare concludes four trends will dominate the future of U.S. energy behavior. First, the increasing need for imported oil. Second, a pronounced shift toward unstable or unfriendly suppliers. Third, a greater risk of antiAmerican or civil violence. Fourth, rising competition for a diminishing supply of oil.

\footnotetext{
${ }^{5}$ Securitization here is defined as making the continued availability of oil a matter of national security, and something that may be safeguarded with military force (Stokes and Raphael 2010). For a traditional description of securitization, see Walt 1991.
} 
As almost a quarter of U.S. oil imports come from Latin America, the region is one of great importance to U.S. national security.

Klare laments the U.S. is not closer to energy security, and closes with the argument for a "paradigm shift" on energy, defined as a need to move to a post-petroleum economy. However, Klare is short on practical ideas. Klare argues for autonomy and integrity, but just as his earlier argument on a paradigm shift, he is short on details. Klare mentions the appeal of independence; however, his argument appears misguided as oil is traded on the international market, and no country is ultimately immune to resource scarcity or gluts. ${ }^{6}$

Klare and Volman (2006) continue with Klare's earlier themes and focus on China. The authors maintain as world demand for oil increases, the U.S. and China have two options: cooperation or competition. As the U.S. expands its military presence where African oil exists, direct competition with China may result. Competition is natural, as China seeks to satisfy its demand for resources. Regardless of whether U.S. and China cooperate or compete, the authors maintain that Africa will increasingly become strategically important as the exploitation of presently known oil fields cannot keep up with increasing world demand. The authors were negligent, however, in the additional mention that oil revenues may also weaken domestic institutions in African nations, an argument known as the resource trap. Centralized power structures in weak states may

\footnotetext{
${ }^{6}$ Autonomy is defined here as the right to buy oil without promising security guarantees or political favors. Integrity is defined here as decisions on energy policy are made in accordance with fundamental American values and long-term interests in mind.
} 
allow African leaders to reach directly to the people for electoral support, bypassing institutions, as is often seen in Latin American radical populism.

At the theoretical level, Daniel Yergin (2006) argues energy security is a concept based on a 1970s model, resulting from oil shocks during that era. This concept is dated, and must change. Our current system dates to 1973, and Yergin argues for a new framework. Yergin offers some comments about energy "integration," but in the economic sense. Also, his use of the term "collaboration" may be considered an early foray into the idea of "energy integration." Yergin offers a solid definition of "energy security," and how the definition is relative to different countries because of the individual challenges each faces.

Yergin's framework argues that to maintain energy security, countries must abide by four principles: diversification of supply; resilience (to provide against shocks); recognizing the reality of integration (there is only one global oil market); and, the importance of information. Despite these principles, Yergin argues for a conceptual expansion. First, the energy system is global, and both China and India need to be engaged. Second, we must acknowledge the entire energy supply chain needs protection. Supply chain protection is fundamental, as interdependence and the growing scale of the energy trade requires collaboration among producers and consumers to ensure its security. Yergin closes with the argument that diversification will be a fundamental starting principle of energy security for oil and gas. Yergin adds this requires the development of a new generation of nuclear power and "clean coal" technology, as well as investment in new technologies (i.e. conversion of natural gas into a liquid fuel). Written before the 2011 Fukushima nuclear disaster in Japan, Yergin should not be 
criticized for his inability to accurately predict a potential downward trend in use of nuclear energy. Nevertheless, in a world of energy interdependence, energy security will depend on how countries manage their relationships with each other, whether bilaterally or multilaterally.

Carlos Pascual and Evie Zambetakis consider several aspects of energy security (Pascual and Elkind, 2010). The authors argue for over a century energy, politics, and power have been inextricably linked as a force in international security. The authors continue to explain the complex geopolitics of energy. Countries can use energy wealth as leverage to strengthen regional influence (i.e. Venezuela, Iran, Russia), against their more vulnerable neighbors. Countries with energy wealth could complicate U.S. interests, through the use of national oil companies (NOCs) to carry out political goals. ${ }^{7}$ Moreover, unlike private firms, NOCs may have a wider set of objectives than maximizing profits. For example, as NOCs increase the political discount premium, this encourages greater employment and increased output in the short-term, but results in lower employment and lower cash flow in the long-run (Hartley and Medlock III 2008). Last, NOCs significantly underperform private firms in efficiency and profitability as political preference for state oil often comes at an economic cost (Wolf 2009, 2642).

Victor, et al. use social science to explain the variation in the strategy and performance of NOCs (2012). NOCs arose sporadically in the twentieth century in states with a strong corporatist tradition. These states justify involvement in the gas and oil sector to control the commanding heights of the economy. Initially, NOCs had little

\footnotetext{
${ }^{7}$ NOCs dominate the world's oil and gas industry and although the numbers are not exact, what follows is very close: regarding oil, NOCs own $73 \%$ of the oil and $61 \%$ of the production process on the planet; regarding gas, the numbers are $68 \%$ and $52 \%$ respectively (Victor et al 2012).
} 
leverage over international trade in oil. This changed in the 1960s and 1970s when developing countries with large gas and oil reserves became more aggressive. This aggression was fueled by resource nationalism. The associated nationalizations of once private oil and gas firms turned the structure of the energy markets on its head (Victor et al 2012, 10).

The decline of oil prices in the 1980s compelled NOCs to pursue different strategies to come to terms with falling revenue (i.e. vertical integration; international integration; attempts to attract foreign capital). In the 1990s state control over oil waned, and lower oil prices left governments devoid of revenue, again compelling change or adaptation. Soon thereafter, the emergence of the Washington Consensus favored economic liberalization and a shrinking of the state, which took a particularly strong hold in Latin America. Prices again rose in the 2000s, which varied government responses. Some saw the increase in price as justification for a greater state role in this sector, while others added obligations for NOCs such as procurement requirements and domestic gasoline subsidies. Some governments went beyond this and pushed NOCs to take on roles historically under the purview of governments.

Stokes and Raphael (2010) argue the construction of a U.S. global order, the U.S. military's role in sustaining such an order, and the necessity of controlling oil supplies are all interrelated. The authors maintain there is a strong relationship among energy security, coercive power, and the wider U.S. grand strategy. Despite an increasingly globalized order, the U.S. pursues a "dual logic," working to maintain a liberal order, providing a safe environment for U.S. national and transnational capital. This logic simultaneously ensures U.S. national interests are pursued concomitantly within a 
globalized order. Nowhere is this dual logic more salient than when examining the pursuit of energy security via the control of oil. Because the flow of oil from producers to consumers is mediated by an international market, the market ensures U.S. energy security cannot be divorced from the energy security of others. Energy security is part and parcel of U.S. foreign policy in the postwar order, and the defense of international markets has been a paramount concern for U.S. planners. Stokes and Raphael complement the work of Klare and Volman (2006). In the context of Latin America, Stokes and Raphael provide data in support of their argument using Colombia and Mexico as case studies, as well as providing anecdotal mention of other countries in the region.

\section{Conflicts over the Spoils of Natural Resources, the Local Level:}

At the domestic level, potential for conflict also exists regarding the discovery and exploitation of commodified natural resources. One type of conflict results from a particularly prevalent form of economic corruption, which confounds market efficiency and adds cost to a product without increasing its value. Capturing of rents forms a major aspect of state involvement in energy production in Latin America. The literature on rentism dates to the early 1970 s, although the concept has a deeper history. ${ }^{8}$

Anne O. Krueger (1974) develops a model for competitive rent-seeking. Krueger offers a solid and simple explanation of rent-seeking, and was the first author to coin the

\footnotetext{
${ }^{8}$ Rentism is remuneration for one who possesses a resource instead of pursuing other economic activities, and is behavior that seeks payments such as advantages, benefits, or fees for individuals or groups through the exercise of political power (Laserna 2006).
} 
term; however, Gordon Tullock was the first to write on this topic. Krueger uses the example of licensing as a valuable commodity, and the costs associated with licensing often result in resources being devoted for competing for such licenses. The value of rents associated with import licenses can be relatively large, and there are three political implications of rent-seeking. First, the government is caught in a dilemma that by restricting entry, it shows favoritism. If competition for rents is allowed, income distribution is less unequal, and has less favoritism, but the costs associated with restrictions will be higher. Second, the existence of rent-seeking affects people's perception of the economic system, and the market mechanism may be considered suspect. Third, all market economies have some form of rent-generating restrictions. A continuum exists between having no restrictions whereby entrepreneurs would seek windfall gains by adopting new technology and anticipating market shifts correctly. At the other extreme, perfect restrictions exist where regulation is all pervasive, and rent seeking is the only way to achieve gain. In the latter system, entrepreneurs would devote all their time and resources to capturing windfall rents. Additional authors during the 1970s provide arguments on economic regulation, but most are heavily econometric, not helpful for defining rents as an economic reality, and have limited application for policy (Stigler 1974; Posner 1974; Posner 1975).

There are three basic categories of rents: natural resource; contrived (i.e. government monopoly); and, geopolitical. Geopolitical rents reflect revenues the state extracts from the global community through strategic alliances, humanitarian concerns, or terror threats (Auty 2007). Rents associated with natural resources are central in this dissertation. 
Gordon Tullock (1988) distinguishes between "good" and "bad" rents, and argues market forces erode inefficient monopolies over time. Well-organized groups have always possessed advantages in preserving wealth. To become wealthier, we must have continuous innovations. Rent-seeking inhibits innovation as energies are instead spent securing rents. However, rent-seeking is a very important part of the underground economy where transactions are not recorded or taxed. Here, much rent-seeking is concealed because it is often illegal. Because such economic activity goes unrecorded, it is difficult to measure its impact on an economy. Using Mercantilist England as an example, Tullock closes with the argument that if a rent-seeking state was dismantled once, it can be dismantled again. Although a form of corruption, rentism may allow wealth generation among those historically excluded from a system. Such wealth generation may come in the form of informal economic activities.

The special privileges that can be obtained through rent-seeking are not secure. A rent-seeker may be replaced in the future by another in government favor. Furthermore, the rent-seeking system treats property as if it were a special privilege. Thus, it is not possible for a person to move outside of a system and engage in business activities because they are always dominated by a vast rent-seeking apparatus. Ultimately, rentseeking is a costly phenomenon that severely damages a society; however, measuring that cost, or even putting one's finger on it, is difficult (Tullock 1989; Tullock 2005).

Erich Weede (1993) argues that although Dependency Theory is popular because it blames the privileged for making and keeping people poor, a more valid reason is how rent-seeking causes price distortion. Rent-seeking behavior attempts to distort markets and incentives, and avoids competition. Monopolists try to maximize profits by selling at 
a higher price than what is found in a competitive market. Governments tolerate these distortions because they reap political, economic, and social benefits. In the struggle for distributed benefits, the poor most often lose. To end rentism quickly, trade restrictions must be removed, and the market must be allowed to set prices.

Marco Cupolo (1988) places the degenerating effects of rentism in the context of Venezuela. Venezuela has vast resources, and developed a peculiar democratic system via an oil strategy supported by oil rents. Rents do not have the multiplying effects of capitalist investment. Instead, rent depends on a primary good, and profitability is favored by specific conditions and advantages. Such profitability does not follow the same trends set by capitalist development. As a result, oil rentism leads to a centralized decision-making process because local and state governments are dependent on central government allotments. Public administration is not a neutral apparatus, but used as a distribution mechanism. Rupert Pritzl (2000) continues with this argument and suggests how rentism is unproductive for society.

Jose Ignacio Moreno Leon (2004) provides a similar argument. Rentism applies to those who benefit from rents emanating from the state, and who have not realized any productive effort to obtain such a benefit. Problems of rentism include the monetary distortion that affects competitiveness, and is often referred to as the Dutch Disease. ${ }^{9}$ Seeking of rents increases costs, absorbs limited capital resources and labor, and

\footnotetext{
${ }^{9}$ Dutch Disease is a term originating in the 1960 s to describe the high revenue generated by natural gas discoveries in the Netherlands. This term refers to the consequences resulting from large increases in a country's currency, primarily and historically associated with discoveries of large natural resource deposits; however, may result from any large influx of foreign currency into a country (i.e. FDI, foreign aid, increase in natural resource prices). The effects of Dutch Disease decrease the competitiveness for exports of the affected country, and increase the quantity of imported goods.
} 
consequently disincentivizes other productive activities that cannot compete against cheaper imported products.

Schuldt and Acosta (2006) summarize some of the major consequences of rentism: Dutch Disease, dependency arguments, elevated profit rates, how commodity prices aggravate development plans, and associated export booms that distort economic sectors. The authors argue for a new energy policy to allow autonomous development whereby energy is used to transform an economy and society.

Rentism is manifested via the acquisition of influence in decision-making through the individual or group which obtains control and the resulting product of an existing resource. Essentially, rentism is an attitude, a human behavior that occurs regardless of whether there is a resource to exploit (Laserna 2006). Strong state institutions may keep rentism in check. For example, a state that is politically weak but economically strong, offers the most favorable conditions for rent-seeking and related behaviors. Sam Moyo and Paris Yeros (2014) echo Laserna’s early arguments.

Laserna (2010) takes earlier theories on rentism and applies them to Bolivia and its natural gas resources. In the case of Bolivia, protest action increases with the anticipation of rents to exploit. The rentism trap allows producers access to resources whose utilization allows them to multiply their wealth. The search for rents is not always a problem, but becomes one when the seeking of rents absorbs much of the creative energy of the people.

Paul Collier (2007) discusses rentism in the context of development. He explains national resource booms, and their associated exports, cause the currency of the exporting 
country to rise in value against currencies of other countries. The exporting country's other activities become uncompetitive despite these other activities possibly being the best vehicles for technological progress. Without aid or natural resources to export, the only way a country can pay for imports is through exports, as exports generate foreign exchange. Collier explains that resource rents make democracy malfunction as resourcerich democracies essentially underinvest resource export wealth. When they do invest, they do so poorly through grandiose white elephant projects. Echoing to the argument of weak state institutions, resource-rich countries without associated checks and balances are likely to misuse opportunities in ways that limit growth. Limited economic growth closes the path toward democracy.

\section{Oil and Natural Gas Writings, the Early Years and in the Context of Latin America:}

Many early energy writings focused on the oil industry as well as the world energy market in a very general sense. These works are required reading to grasp the complexities of the oil business and industry, and often provide clear definitions, general explanations, and models of the oil market (Hartshorn 1962; Frankel 1969; Kennedy 1974). Later works were often technical and centered on the risks inherent in the oil business. For example, M.A. Adelman (1972) offers a clear example of a work concerning risk. Adelman offers several theses, of which there are four of relevance here. First, the crude oil industry is inherently self-adjusting. Second, the adjustment mechanism is always under strain. Third, the discovery of new oil-in-place is unpredictable, and it is nearly impossible to calculate the odds of finding a reservoir in a particular place. Fourth, the more intense the development, the higher costs and greater 
incentive to seek oil-in-place. Later, Stephen Kobrin (1979) defines "political risk" as falling into two areas. First, the phrase concerns unwanted consequences of political activity (i.e. host government interference with business operations). Second, political risk is defined in terms of events (i.e. political acts, constraints, or both) imposed on the firm. In his work, Kobrin also laments the lack of an analytical framework for assessing political risk.

After the initial oil crisis of 1973 and the later manifestation of 1979, much of the energy literature centered on nationalizations and the relationships between energy firms and the countries in which they operated. Literature on nationalization and nationalism will be addressed below in a separate section.

A seminal work in the post oil-crisis environment is Louis Turner (1978), who takes a critical look at the political relationships of major oil companies with the countries in which they operate. The relationship between national governments and large oil companies is one impossible to ignore, and Turner's work falls into the category of those that consider the actions of non-governmental actors and subsequent implications on transnational relations. Similar to Adelman (1972) and Kobrin (1979), Ernest J. Wilson (1987) argues for the need to reintroduce the market into political analysis, and offers the Petro Political Cycle (PPC) as a framework for such analysis. Wilson argues energy work is largely descriptive, noncumulative, and lacks theory; he challenges political scientists to familiarize themselves with social behavior and institutions across various levels of analysis. Wilson breaks down the field into three theoretical approaches (neoclassical economics; regime paradigm; the petro-political 
cycle, $P P C$ ). Per Wilson's PPC model, petro-politics at market peak will differ substantially from that at the bottom.

Recent literature on oil markets supports Wilson's 1987 argument regarding the lack of theory in energy writings. Morgan Downey (2009) offers an excellent overview of the oil industry from upstream (research and development) through downstream (retail). Downey provides a basic understanding of the history of the oil industry, oil chemistry, drilling processes, refining, storage, oil's seasonality, and emerging technologies in the sector. Downey delivers a separate section on the basics of the oil markets, which explains oil prices, trades, and risks. Downey provides a good foundation to understand aspects of the market and investment areas of the oil business. Giana Bern (2011) also contributes to the energy literature with the basics of energy investing. Bern provides basic definitions and offers suggestions on energy investing. Bern's definitions are specific to the energy industry, and she offers examples of how to look at the energy market from a financial perspective.

Daniel Yergin $(1991 ; 2011)$ provides seminal works that examine the history of oil, and its inextricable links to security in the modern world. Recent publications complement Yergin and place energy, particularly oil, in its historical context regarding nationalization, politics, security, and power (Graetz 2011; Painter 2012).

The International Energy Agency's (IEA) special report on the outlook of world energy investment (2014) complements the works of both Downey and Bern. Of note in this report is how decisions to commit capital to the energy sector are increasingly shaped by government policy measures and incentives, rather than competitive market signals. In many countries, governments have direct influence over energy sector investment via 
state-owned companies. Private sector participation is essential to meet energy investment needs in full.

Mobilizing private investors and capital requires a focused effort to reduce both political and regulatory uncertainties, and the absolute need for new technology creates space for greater private participation and involvement. The report maintains there is an expectation that the surge in new liquefied natural gas (LNG) that is transforming markets will need to be tempered by the reality of the associated high cost of LNG infrastructure and transportation over long distances (IEA 2014). This is an important perspective, as for many emerging economies, keeping up with electricity demand is a major investment challenge.

Although models offer an ideal-typical explanation of markets, realities differ across regions and political systems. Models often do not consider local concerns such as nationalism, government intervention in markets, corruption, or geopolitical responses to regional events. Variations in the local context are clearly manifested in Latin America, the focus of this dissertation.

\section{The Latin America Context}

Literature on energy in Latin America is often limited to vague ideas, notions, and suggestions about the sector. A common theme to writings on Latin America include generalities concerning the regional challenges in the development of oil and gas fields, and subsequent exports. Kang Wu and John McMahon (1995) provide a good history of Latin America and its hydrocarbon sector, as well as demonstrate pitfalls and 
opportunities amid regional stability and instability. Paul Wagner (1998) provides a discussion of the legal aspects to consider in Latin America. Fernando Sanchez Albavera (2006) argues Latin America can advance toward a new energy order if new sources are explored, and if they use current sources more efficiently.

Carlos Battle, et al. (2010) assess the evolution of the regulatory framework of electric power market reform in Latin America, and conclude that investment in energy generation is shown to be a key driving force behind major changes in energy policy. This source provides a good summary of the early 20th century Latin American energy sector and associated state influence.

Some writings on Latin America are driven by issues other than those with an integration rationale, or that center on the relationship between the state and energy firms. Mariana Zilio and Marina Recalde (2011) express interest in global warming (climate change). The authors analyze the relationship between economic growth and energy consumption in Latin America and the Caribbean. They maintain energy consumption at the aggregate level is an indicator of economic activity. Continuing with environmental literature on energy in Latin America, Claudia Pardo and Belizza Ruiz (2011) discuss sustainability and environmental issues relative to energy production and consumption in Latin America and the Caribbean. The authors argue the importance of understanding energy trends in the region with a view towards low-carbon opportunities while meeting energy needs for poverty reduction.

Recent articles explain the potential and opportunities in Latin America energy markets. As early as 2011, a shift in the gas industry was detected whereby the "capital" of energy was believed to be returning to the Western Hemisphere (Jaffe 2011). An 
energy boom in the Americas may cause producers in the Middle-east to think about their positions and power relative to energy. Regarding the practical reality of energy production, development, and integration, there is great potential in Latin American energy markets. Nevertheless, challenges remain regarding struggles with decreased production and weak prices, which are impediments to development, to include the funding of social programs which are often heavily dependent on oil revenues.

Types of Nationalism, to Include Resource Nationalism:

The most common driver of resource nationalism in oil exporting countries is the failure of export revenue to be converted into modern social services, employment, and an improved standard of living for citizens outside of the energy sector. Despite attempts to alleviate economic disparities and build infrastructure such as schools or clinics in the host country, the independent oil company (IOC) cannot completely offset local government failure.

Nationalism is an oft-distorted term, and there is more than one aspect to the concept. Breton (1964) argues where societies invest in nationality, the rate of return on this investment is the redistribution of income in favor of some or all the middle class, not in the creation of the maximum amount of wealth. Similarly, Johnson (1967) argues that the economist considers nationalism a driving force to accelerate developing economies on the one hand, and on the other is a major political influence. Johnson defines the term as a state of social psychology or political sentiment that attaches value to the national group. Johnson next explains the methods available to satisfy the taste for nationalism. First, confiscation which includes the forced transfer of property, and 
conversion of private into national employment. Second, there is an investment of resources favoring the national group. Such behavior, per Johnson's analysis, tends to direct economic development along specific lines (i.e. symbolic value; jobs for middle or educated classes; state control over enterprise). Nationalism arguably directs economic policy towards the production of psychic income in the form of nationalist sentiment, but does so at the expense of material income. Breton and Johnson offer a good starting point for a discussion of nationalism.

George M. Ingram (1974) explains some divergences in the meaning of nationalism; however, most relevant to this dissertation is that of economic nationalism. Economic nationalism is defined as the force that aims to maximize and develop the commodity and potential of a nation and the well-being of its people. Economic nationalism asserts that control over a nation's economy should be in the hands of nationals and nationals should have preference over foreigners in reaping the benefits of business and economic opportunities in the country. Under economic nationalism, several factors give rise to a nationalist resentment of foreign investment regarding the general investment climate in a country: ideology; political situation; economic situation; relationship with the host or mother country; and, bargaining power. Much of the literature from 1973 through the early 1980s centers great attention on the "oil crisis" resulting from the nationalization of oil resources and the formation of the Organization of Petroleum Exporting Countries (OPEC) cartel.

The concept of sovereignty over natural resources originates in United Nations (U.N.) discussions and subsequent resolutions dating to the early 1950s (United Nations 1962, 1), and was based on the principles set forth in United Nations General Assembly 
(U.N.G.A.) Resolution 1803. The U.N.G.A. reiterated the “...the inalienable right of each State to the full exercise of national sovereignty over its natural resources..." and that such a right has been recognized by the international community. Moreover, according to the U.N., each state is entitled to determine the amount of possible compensation for its resources and any disputes should be settled in accordance with the laws of the state $(1974,238)$. This concept has parallels with that that of the Calvo Doctrine, with its roots in $19^{\text {th }}$ century Argentina. ${ }^{10}$

Nationalism does not exist in a vacuum, however. Peter Katzenstein (1978) analyzes how the domestic structures of advanced industrial states shape political strategies in the international political economy, whereby the management of interdependence is a key problem that all advanced industrial states confront in the postwar period. Despite the growth of different kinds of international interdependencies, the nation-state remains able to shape strategies of foreign economic policy. Katzenstein's research echoes to developing countries.

Abdulhady Hassan Taher (1982) argues that change in the international oil industry would have happened without OPEC as market forces were the driver; however, it was OPEC that accelerated this change. Exponential rates of demand growth pressed on a finite reserve of a unique and non-renewable resource - oil. Differences in logics between private and national oil companies exist. IOCs operate according to private

\footnotetext{
${ }^{10}$ Many contracts executed in Latin America contain stipulations for legal redress with their roots in the Calvo Doctrine. Under this doctrine sovereign states enjoy freedom from interference by other states, that aliens are not entitled to privileges not afforded to nationals, and that aliens should seek redress for grievances only from local authorities (Martin 1968).
} 
business incentives. NOCs operate according to government objectives and incentives that caused their initial creation.

George Phillip (1982) provides an historical work on the oil industry in the region, and maintains the state apparatus, compared to other regions of the world, is more or less developed. During the 1920s, international corporate capitalism was at its peak, and at that time the balance of international power favored firms as it would likely never do again. However, once oil was discovered in the Middle-east, Latin America began to be seen as a backwater. Late twentieth-century technological advances in oil and natural gas recovery may once again create an energy hub in Latin America.

Phillip (1982) argues state oil companies in Latin America have been rational in that they followed an easily understood logic. In the Latin American context, gas prices are a major focal point for political unrest. However, conflict need not always result. In the right circumstances, a state oil company will prove a valuable instrument in the hands of a government that has a clear and realistic idea of its strategic objectives. Phillip maintains there would be a likely trend of increased state control over the commodity.

Jack K. Edwards (1992) examines privatization trends in Latin America and looks at the positives and negatives, the state's role in the economy, the extent to open the economies in the region, and related implications for growth. Edwards argues for a more active role for the state in development, and suggests the region faces similar challenges to that of the late-nineteenth century. These challenges were also difficult to resolve. The region appears to have come full circle, as the 1990s experienced a neoliberal push via the Washington Consensus, and the 2000s have seen a return to export-led growth fueled by oil, gas, and mining. 
After a lull in writings on energy nationalizations in Latin America, there was a resurgence in the 2000s that continues today. Alexia Brunet and Juan Augustin Lentini (2007) define resource nationalism as something exemplified by the global trend of placing the world's oil reserves under the control of national oil companies and out of reach of IOCs, except on a low-margin, service contract basis, which prompts some Latin American countries to place limits on foreign investment in their energy sector. Kristina McQuaid and Steven Otillar (2008) look at the Brazilian energy market, and imply the government is often the problem as there are multiple layers of taxation, permitting, and customs through which solutions must wander.

Paul Stevens (2008) defines resource nationalism as something assumed to have two components: limiting the operations of IOCs and asserting a greater national control over natural resource development. This idea has a long history, and not only in the context of oil and minerals. Drivers of resource nationalism are many, and are a function of history as much as of a country's current context. There is an ideological component to resource nationalism strongly linked to the perceived role of the state in the operation of the national economy. Stevens concludes resource nationalism is a cyclical phenomenon.

Resource nationalism cannot be discussed without consideration of the resource curse. ${ }^{11}$ According to Townsend (2008), resource nationalism exists when a country seeks greater shares of the returns from natural resources for the country's people, possibly by nationalization of resource-based industries like mining, oil, or natural gas

\footnotetext{
11 The resource curse concerns countries rich in natural resources that have been unable to use that wealth to boost their economies or reduce poverty (Frankel 2010).
} 
extraction. Countries suffering from such a curse have had lower economic growth and less poverty reduction than countries poor in natural resources. Often, countries whose economies are dominated by resource-extraction industries tend to be more repressive, corrupt, and badly managed partly because there is more wealth to fight over. Despite the ubiquity of this concept in academic literature, this curse is not always a foregone conclusion in countries that commodify their natural resources.

Contrary to the resource curse argument, Heilbrunn (2014) argues oil production leads to an expansion of a country's economy and resource revenues increase society's wealth. Increases are evident in the organization of service industries, banking, housing, security, and consumer goods networks. Non-oil producers move into niches as middlemen or distributors of consumer goods; however, this process takes time. Heilbrunn finds oil sector expansion has a ripple effect throughout the economy evident in health care, education, and urban living conditions.

Vlado Vivoda (2009) argues increased commodity prices result in governments rethinking contract terms, and seeking higher taxes and royalties. It is during times of high commodity prices when resource nationalism surfaces, as it is a by-product of higher prices, which often translates into "anti-Western" IOC campaigns. Conflicts between host governments and multi-national corporations (MNCs) usually center on the issue of divisions of rents. Vivoda argues there are no "silver bullets" for IOCs, and we are likely to witness the demise of major IOCs, once dominant players in the international oil industry. What Vivoda overlooks is the ability of NOCs to form partnerships with IOCs as needed and with mutual benefits. As the NOC benefits from IOC advances in 
technology, so does the IOC benefit from access to host country upstream markets. Vivoda is correct as the heyday of IOCs is gone.

Berrios et al (2010) explain that neither populism nor ideology are responsible for hydrocarbon policy choices in Latin America. Timing and the starting point are examined regarding influence in nationalization policy choices. The timing hypothesis asks whether ideology is subsumed by regional trends (i.e. nationalizations of 1970s, and privatizations of 1980s). The starting point hypothesis argues that economic considerations, not ideology, determine the policy countries pursue. Politics is not completely subsumed by economics, but clearly condition political responses. Essentially, nationalizations are not one-off events, but represent a long-term conflict between states and foreign companies.

David Mares (2010) defines resource nationalism as the notion that natural resources are a national patrimony to be used for the benefit of the nation, rather than for private gain. Moreover, under resource nationalism, the commodity itself is believed to have intrinsic value not determined by the market. Energy security and resource nationalism are not inherently at odds with one another, but a balance must consider both domestic and international interests in the hydrocarbon sector. Mares argues inclusiveness, competitiveness, and leadership (defined here as innovation and risk acceptance) all interact to determine the choice of an energy policy that emphasizes resource nationalism and energy security.

Victor, et al. (2012) explains most oil was controlled by the "Seven Sisters" until the 1960s and 1970s. During this period, exporting countries became more assertive as the creation of NOCs, fueled by resource nationalism, included then-popular state-led 
economic theory. The formation of NOCs radically changed the market structure, as NOCs now control most natural resources on the planet.

Derrick Hindery (2013) places resource nationalization in the context of Latin America, with a focused examination of the concept at work in Evo Morales' Bolivia. Hindery argues the profits from extraction are increasingly aimed at industrialization, while social spending, as well as the often-damaging effects on communities and environments, largely parallel those that emerged under neoliberalism. The government's economic vision entails modernization and industrialization which is guided by a strong state, and uses profits from natural resources in conjunction with its transnational partners.

Bebbington and Bury (2013) and Perreault (2013) advance the indigenous and subsoil argument, and focus on how natural resources relate to the construction of nationalism and the relationship between nature and nation. Perreault asks how this relationship hinges on and informs understandings of identity, citizenship, and national space. Bolivia is the case study for this dissertation, and these questions are placed in the context of the politics of natural gas. Natural resources and associated extraction are integral to the production of a nationalist ideology.

\section{Populism in Latin America}

Nationalism is a potent force which cannot be suppressed eternally, and resurfaces throughout contemporary Latin America, particularly in the cases of Bolivia and Brazil. Nationalism, economic or otherwise, flirts heavily with populism. That nationalism is 
often associated with populism makes for interesting domestic and international relationships. Weak state capacity in Latin America preceded, although was not entirely responsible for, the rise of populism and the leftward shift in the region since the 1980s. Other antecedent variables certainly contributing to populism's rise are historically high rates of poverty, unchecked and endemic crime, high levels of illiteracy, corruption, and lack of economic opportunity in various countries in Latin America. Moreover, as populations tire of ineffective political parties and the inability of elites to create economic opportunities, the appearance of historical outsiders onto the political stage is indicative of populism's recent development of an ethnic component.

Ethnic based populist movements challenge traditional elites as was the case with classical populism; however, they are particularly influential among historically marginalized populations in their respective countries. Ethnic-based populism opens a new chapter in democratic rule, possibly weakening liberal democratic institutions, in Latin America. Below is a brief and mostly chronological review of pertinent literature on Latin American populism.

Robert Kaufman and Barbara Stallings (1984) claim populist cycles came about in Latin America because of the 1980s economic and political crises. Michael L. Conniff (1982) argues urban populism was a new or relatively unstudied political topic that has appeared throughout the Western world. Populist movements were multi-class, contained expansive electoral coalitions, and, in the Latin American context, were mostly urban. These movements were led by charismatic personalities who promised to redress popular grievances as well as build social solidarity. The enduring legacies of Victor Paz Estenssoro of Bolivia and Getúlio Vargas of Brazil loom large. 
Torcuato S. Di Tella (1997) refers to the idea of caudillismo in Latin America and similar traits relative to populism. ${ }^{12}$ Populism gives precedence to representing the interests of the masses with the "establishment" as their main antagonist. Arguing what most later scholars presently maintain, Di Tella claims populism is the enemy of liberal democracy.

René Antonio Mayorga (2002) argues Andean democracy is regressing, and representative democracy is leading towards authoritarian regimes or semi-democracies. Mayorga considers the emergence of neo-populist and anti-political outsiders as troubling. Their rise to power exists amid party system collapse and destruction of liberal democratic institutions.

Kenneth Roberts $(1995$; 2006) claims populism is driven from the top downward to politically mobilize people against elites through a dominant personality. The resurgence in populism is attributable to neoliberal and democratic transitions occurring in during the late $20^{\text {th }}$ century. Of note, populist waves coincide with "critical junctures" marking the transition from one development era to another (i.e. post-1930 through ISI; the post-1982 Debt Crisis; after the Washington Consensus began to wither).

Demmers, et al. (2000, xii) argue during the last two decades of the twentieth century, populism in Latin America experienced an economic, social, and political transformation, the severity and depth of which may only be compared to the impact of the Great Depression on the region during the 1930s' international crisis. However,

\footnotetext{
${ }^{12}$ Caudillismo is defined as a system of political and social control based on the leadership, usually irregular and military-centric, of a strongman, or caudillo.
} 
during the 1980s-2000s populist parties in Latin America became unrecognizable from earlier manifestations.

James Petras (2008) predicts as U.S. hegemony decreases its reach, Latin America's "brand" of neoliberalism will expand globally. Petras claims despite the recent U.S. recession, Latin America will not slow down its growth, thus demonstrating a "de-coupling" of the two regions' economies. However, the article lacks adequate supporting data. Petras' prediction regarding the Bolivian right is misguided, and the Bolivian people have reelected Morales as well as created and implemented a new "plurinational" constitution which includes some granting of regional and indigenous autonomy. Essentially a "resurgent right," in the case of Bolivia at least, appears to dither and is incapable of mounting an effective counter-strategy.

Along the lines of Torres and Roberts, Ignacio Walker (2008) maintains both old populism (more autocratic than democratic) and new populism reflect internal contradictions regarding representative democracy and its associated institutions. Walker's neo-populism, differs from its traditional roots because of its democratic nature during the "third wave" of Latin American democratization.

Paul Cooney (2006) attempts to examine how the accumulation crisis of the 1970s, the debt crisis of the 1980s, and the influence of both the International Monetary Fund and the Washington Consensus facilitated neoliberalism as an ideology. Ironically, despite Latin American rejection of neoliberal policies, popularly elected leaders maintain such policy implementation and accommodate national elites and Washington rather than those who brought them to power. 
Mitchell Seligson (2007) attempts to answer several questions with aggregated empirical and survey data from across Latin America. Seligson asks whether leftist sympathies predominate in Latin America, if Latin Americans support populism by concentrating power into the hands of the chief executive, and whether those favoring leftist orientation are less supportive of democracy. Seligson finds that despite more leftists being in power in Latin America, the median voter remains slightly to the right of world opinion. Additionally, despite a rightist orientation, there was a shift to the left between the 2004-2006 period, and ideology varies sharply from one country to another in the region.

\section{Energy Integration in Latin America:}

Historically the political economy of oil in Latin America has two basic groupings: exporting and importing nations. Separately, the legitimacy of public enterprise found in Latin America derives from the colonial Hispanic idea of the sovereign's right to regulate, control, and own national wealth. It is in this sense that the Latin American state enterprise includes a mix of political and economic goals. In addition to its basic inputs, the state enterprise is expected to support the overall national planning process, provide employment, afford other social benefits, and turn a profit. These functions are enveloped in a country's national sovereignty, and ultimately the state's relationship to its public enterprise is central to understanding Latin American energy policy. The magnitude of NOCs pushes them to assume roles in the international political economy likely beyond what their founders intended. All integration projects in 
Latin America must carefully consider national sovereignty in a region known for fragmentation and division.

John Wirth (1985) looks at the blends between nationalist and free-market approaches appropriate for each nation in Latin America, an old debate in the region. Wirth finds there was less emphasis on the risks of cooperation at a time when high oil prices challenged the region's economies. It is here that early mention of energy integration surfaces in the literature.

Wirth explains regional integration was the theme of early Latin American nationalists, and one not yet developed beyond the setting up of organizations. Market forces and the lack of capital propelled such arguments for integration. Petrolatín was to pool together the resources of Brazil's Petrobras, Venezuela's PDVSA, and Mexico's PEMEX. This idea was dead on arrival because of the joint challenges of the debt and interest rate crises facing the region during the early 1980s. Additionally, Kang Wu (1995) argues that in all but a few countries in the region natural gas is an underutilized resource, and regional integration has been a great challenge to countries in Latin America.

John Wirth (2001) presents the hypothesis that Latin American public petroleum enterprises face problems that are not inherent in government ownership, but derive from the nature of the government-imposed environment in which they operate. Alfred $\mathrm{H}$. Saulniers (2001) adds that many of the current adversities of Latin American public petroleum producers are rooted in their past, as instability plagued their early years and recurred throughout their history. Incompetent management is also a factor. 
Marco Aurelio Tavares (2005) argues of the problems and potential solutions for the development of an integrated natural gas industry in the Southern Cone of Latin America whereby nothing in the region follows a rational model, logic, or even market signals. There are even challenges inherent in regional affinities and binational agreements. Tavares' work aligns with that of Gerardo Honty (2006), who argues it is difficult to find the required harmony in Latin America to increase energy integration. Despite physical connections, there is little energy integration in the region.

Rolf Linkhor (2006) argues that in Latin America, like everywhere else, energy is inseparable from politics. There are positive and negative aspects to energy nationalization, but Linkhor advocates for energy integration in the region. Continuing in this vein, Porta (2008) argues there is no easy path to energy cooperation, or eventual integration, in Latin America for myriad reasons including conflicts over national autonomy, the lack of confidence in the region, and the resurgence of energy nationalism.

In a 2006 publication, the Comisión Económica para América Latina y el Caribe (CEPAL) argues it is necessary to strengthen sub-regional integration agreements as well as to solidify bilateral electric and gas initiatives. ${ }^{13}$ At the time, there were discussions regarding how to develop policies for energy development, the challenges of petronationalism, the financing of energy integration, and international experiences related to energy integration in petroleum, gas, and electricity. Weintraub (2007) explains the benefits of energy integration among many countries in the Western Hemisphere, to

\footnotetext{
${ }^{13}$ CEPAL is one of five regional commissions of the United Nations, and was founded to encourage the economic development of Latin America.
} 
include Bolivia and Brazil, and includes a brief history of why American countries are the way they are concerning energy integration and cooperation.

Chris Webb (2008) summarizes the arguments of energy practitioners and academics alike. Cooperation in Latin America faltered during the 1990s, and could emerge as a driver of integration in the region. Ideas of pipelines matching Latin American producers of gas to respective consumers exist, but grandiose projects that will connect the region are fraught with logistic and bureaucratic challenges. In 2008, an integrated liquefied natural gas (LNG) market was incipient in nature, and Webb likely could not foresee the emergence of one international in scope resulting from the subsequent natural gas and shale oil boom.

Baritaud and Volk (IEA 2014) remind us that government priority is not integration, but in "keeping the lights on." The authors identify ways to integrate markets over a wider geography, which involve consolidation and coordination. However, there are various barriers to integration including the physical (lack of transmission lines), the institutional (conflicting security and regulatory actions between local and national government), and distributive (where impacts of market integration must be addressed). Addressing these barriers requires action at the intersection of policy, regulation, and markets, which demands a stronger government commitment. Energy integration is not always a government priority or goal, and oftentimes NOCs are politicized entities and unresponsive to the needs or wants of the citizenry.

Li, et al. (2014) look at energy relationships among North American, European, and Asian natural gas markets and seek evidence of convergence and integration for the period 1997-2011. The authors conclude there is not a fully integrated natural gas 
market. The authors remain interested in whether natural gas markets have become more integrated with the expansion of the liquefied natural gas (LNG) trade and shale developments in the U.S.

\section{Methodology}

We should not devote our careers to learning more about Latin America for the sole purpose of learning more about Latin America. Science seeks to generalize, and the more we can apply to other areas what we learn in Latin America, the greater the likely contribution to comparative politics and to political science as a whole (Blanksten 1959, 126).

Latin America provides immense energy resources for export at a time when the region and larger world increasingly require supplies of energy. Historically, many countries in Latin America placed their natural resources under state control and have established both legal and constitutional barriers to foreign involvement in domestic energy production. These barriers are a potential frustration to development of energy and the idea of integration. The case study for this dissertation is selected based on the following variables: energy resources for exploitation, government-run natural resource firms, and energy import/export relations with countries near one another within Latin America.

Howard Wiarda (2001) writes of a shared Latin American culture and Iberian history. This experience refers to a hierarchical and centralized structure in state-society relationships. Within this same vein, there is also a banding together of countries in Latin America, stressing nationalism and corporatism. The intertwined histories of Latin 
American countries offer regional NOCs the ability to share a pan-Latin vocabulary, useful when called upon to fulfill their policy roles (Wirth 1985).

This dissertation develops a case-study of Bolivia and Brazil to assess the relationship between resource nationalism and energy integration. The case is selected based on each country having energy resources or derivative products for exploitation and use, an energy trade relationship between the countries, the presence of governmentrun natural resource firms in each country, and a specific period when resource nationalism is present. Bolivia and Brazil are important for this study because of their proximity, particularly where the supply of natural gas is concerned. Proximity is of great importance as natural gas infrastructure is concomitant with energy integration, particularly supply.

Selection on the dependent variable must be taken in the context that regarding natural resource exploitation in Latin America, one is unable to locate resource firms that operate without host-government influence. Energy integration is related to regional import/export relationships, and proximity is required in natural gas and electricity infrastructure. Arguments may be leveled that the conclusions of such a study will result in the wrong answer; however, there are limited numbers of cases to examine. Selecting on the dependent variable may justify learning how phenomena develop, and may provide insights for future study (Geddes 1990, 149).

This dissertation will help determine if there is a relationship between resource nationalism and energy integration in Latin America. The argument is whether resource nationalism affects a country's ability to integrate. The ability to integrate with other 
countries in the energy sector is a strong precursor to economic integration. Economic integration provides development benefits.

Bolivia and Brazil are like each other in that they are in the same geographic region, have state-run energy firms, trade energy with one another, and have explored the idea of integrating their energy networks. Limiting the research to Latin America results from similar levels of institutional development, shared historical experiences, cultural affinity, a pan-Latin vocabulary regarding government policy, and similar levels of government influence in their economies. A comparative study is suitable for this dissertation despite the concern that it centers on the discovery of uniformities. Uniformities arguably inquire how like to one another ought each system be if we are to adequately compare institutions and processes (Macridis and Cox 1953, 642).

The Western experience is often anathema in its application to the non-Western world; however, to claim Latin America is non-Western is misguided. A comparison of countries in Latin America is required for this study as the region does not fit in the Western/non-Western frame of reference. Attempts to create such a simple categorization is a major problem (Martz 1966, 57). As a counter-argument to the comparative method, major insights into modernization and related social processes did not originate in area studies departments, but in those with an international focus (Rustow 1968, 46). That these scholars took lessons from one region to another is solid justification for applying a comparative approach to Latin America. The Bolivia-Brazil case study is a step in this direction.

In the late-1960s, there was a revolution in comparative politics, which began with several principles (Verba 1967). This revolution looked beyond description, single 
cases, formal institutions and government, and beyond Western Europe to Africa, Asia, and Latin America. Still, the standard model at that time remained the single-country case. Verba argued cultural and structural context was increasingly important. This argument holds true today. Following Verba, but applied across nationalized oil firms, Victor, et al. $(2011,908)$ argue very few governments have typical Western liberal systems regarding policy, but could create stable environments for NOCs.

The comparative method is defined as one of the basic methods in establishing general empirical propositions, and is used in this dissertation to discover relationships among variables, not as a method of measurement (Lijphart 1971, 683). Based on the energy relationship between Bolivia and Brazil, the best approach is the case study. The phenomena under examination are anathema to either experimentation or large- $\mathrm{N}$ studies. The comparative approach is preferred in this dissertation as no opportunity exists that affords systematic control via correlations as is the case in the statistical approach; the number of cases is limited (Lijphart 1971, 684; George 1979, 46). The comparative rationale is used to determine commonalities among the selected countries as well as any relationship between resource nationalism and energy integration. Limiting the focus to Bolivia and Brazil adds greatly to such reasoning.

Essentially, “...the general problem of comparison is extraordinarily difficult for political science, since it is unlikely that we will ever find a true 'experimental' situation, that is, two or more societies which are identical in all respects except for a single, variable factor" (Macridis and Cox 1953, 643). The comparative approach is suitable as this dissertation compares a single issue: the relationship between resource nationalism and energy integration. This relationship is limited to adequately homogenous political 
systems, such as is the case in the aforementioned intra-area countries. An area includes several operational criteria, the most important for this dissertation includes cultural interaction, physical proximity, economic relations, and strategic considerations (Macridis and Cox 1953, 655).

The selection of Bolivia and Brazil requires the flexibility the comparative method affords where explanations of phenomena are examined. In the areas of the natural sciences, and some of the social sciences, the comparative method has been praised as central to the quest for knowledge (Segal 2001, 339). Critics argue the comparative method seeks similarities and ignores differences, confuses similarity with identity, and generalizes prematurely as well as too broadly (Segal 2001, 348). Some interpretations of the comparative approach consider these criticisms as misconceived. The comparative method is one in a suite of methodological tools, and such criticism is misguided.

Furthermore, although numerous commonalities exist among NOCs, each individual parastatal operates according to its own logic. During the oil price decline in the 1980s, NOCs pursued different strategies to confront falling revenue. Organizations like Venezuela's PDVSA became vertically integrated and made inroads into international markets. Others NOCs focused their energies domestically while trying to attract foreign capital. During the 1990s, amid the waning of state control over oil, associated low prices stripped governments of revenues and compelled change. With the rebound of prices in the 2000s, some governments sought greater roles for state ownership, pushing NOCs to absorb government responsibilities to include new social obligations (Victor et al 2012). The increased use of hydraulic fracturing and horizontal 
drilling in the first decade of the twenty-first century has again altered the role of the parastatal; however, how much so is yet to be determined.

Previous research concerning NOCs relies mostly on case studies, and falls into two general bodies: those looking at NOCs in isolation, and others offering structured comparisons across a small group of companies. NOCs are inherently challenging to study, and previous research fell into one of two general camps. On one hand, studies looking at the entire industry offer thin insights applicable to any NOC. On the other, such industry-wide studies offer little on their own as the thickness of regional and individual factors are too complex to comprehend. The in-depth case study, although detailed, weakens the ability for a systematic comparison across cases (Victor et al 2012, 14). This dissertation takes a hybrid approach that looks at the importance of international market integration and nationalism cum populism, then incorporates the case study into the larger, international, context.

Understanding the relationship between resource nationalism and energy integration is challenging as they are connected issues with links to other variables. Common themes will assist in understanding how countries in this study relate to one another in the energy sector. Additionally, this study considers the power and influence resource nationalism has on energy imports and exports, and how to ensure security of supply in a region replete with political, regional, and cultural differences amid its deep and shared history.

The comparative analysis in this dissertation examines the energy relationship between Brazil and Bolivia. This dissertation examines energy relationships in which incidents of resource nationalism are discovered, then draws out generalizations (George 
1979, 43). The case study centers on indicators of resource nationalism in energy exporting countries in their relationship with importing countries. The case study carries out this task through the incorporation of examples of populist regimes in the region relative to resource nationalism and development, then compares fluctuations in levels of imports and exports of natural gas with effects on the presence or absence of the phenomenon of resource nationalism.

Data for this dissertation derives from interviews with energy practitioners in both Brazil and Bolivia, and subject matter experts with each country's parastatal, and secondary sources. All key informants have regional expertise in South America or the energy sector. ${ }^{14}$ Key informants' positions and qualifications include academia, economics, strategic planning, energy sector analysis, risk analysis, and consultancy in both the public and private sectors across varied geographies with expertise in South America. Interviews and discussions with key informants took place between September and December 2017. Secondary sources entail publicly available information (i.e. news reports, ministries' published data for each country, statistical databases, and published interviews). Consumption, production, and proven reserves statistics from energy firms, as well as official government documents also form part of the data.

This dissertation examines the literature pertaining to transactions among the two countries, their respective energy policies, energy firms, and various business and financial databases relative to the industry. Unlike governments which are required to maintain records, private firms are often not. Whereas governments may alter data for

\footnotetext{
${ }^{14}$ Petrobras in Brazil, and Yacimientos Petrolíferos Fiscales Bolivianos (YPFB) in Bolivia.
} 
political expediency, firms may simply destroy or elect to not record it. Such realities limit the reliability of data in any study, and is something that may only be addressed over time through continued research as more information becomes available.

\section{Evaluation of Potential Data Sources:}

Several sources for energy data exist and are evaluated. The databases of the World Bank, International Monetary Fund, and United Nations provide baseline data across economic and social topics relative to Bolivia and Brazil. ${ }^{15}$

The Organización Latinoamericana de Energía, OLADE, produces publications on energy and related topics with a focus on Latin America and the Caribbean. There are twenty-seven member countries, including Bolivia and Brazil. This site holds some price data from 1970 to the present.

The Energy Information Administration (EIA), created by the U.S. Department of Energy (DOE) in 1977, has reliable statistics on the global oil industry. ${ }^{16}$ The International Energy Agency (IEA) derives from the Organization for Economic Cooperation and Development (OECD) as a forum for 30 of the world's most industrialized nations to discuss/agree on policy recommendations. ${ }^{17}$

\footnotetext{
${ }^{15}$ The Comisión Económica para América Latina y el Caribe, CEPAL (The Economic Commission for Latin America and the Caribbean) is a United Nations publication.

${ }^{16}$ EIA data is designed to ensure the U.S. Executive Branch cannot alter data for political favorability.

${ }^{17}$ The OECD emerged in 1974 in the wake of the Arab oil embargo to coordinate energy policies to prevent economic shocks from oil supply disruption. The IEA collects data on global oil inventories, and publishes them in its Monthly Oil Market Report (OMR).
} 
British Petroleum (BP) Statistical Review of World Energy is an industry standard. Gas Daily is a leading trade publication and provides a survey of companies that trade in natural gas to obtain a representative number of deals at each pricing point. ${ }^{18}$

Bolivia's Ministerio Hidrocarburos y Energia holds data on natural gas specific to Bolivia. Brazil's National Petroleum Agency (ANP) manages the auctioning of blocks for exploration, contract exploration licenses, and regulates upstream and downstream activities across the oil sector. The Boletim Mensal de Acompanhamento da Industria de Gas Natural provides Brazilian natural gas data from 2007-2016.

\section{Chapter Outline}

\section{Introduction, Literature Review, and Methodology}

a. Is there a relationship between resource nationalism and energy integration in Bolivia and Brazil; if so, how do these countries experience the phenomenon? Each country has a history of economic nationalism and dictatorship; both experienced development differently while sharing some commonalities during their transitions to formal democracy. The central question of the dissertation can be answered by looking at how each country views its resources and its associated energy trade relationship with the other. Brazil, a major natural gas consumer, and one heavily reliant on gas exports from Bolivia, likely has a different perception of its resources than does Bolivia, which has a less diversified

\footnotetext{
${ }^{18}$ Henry Hub price data, the benchmark price for North American natural gas, may be found here.
} 
economy than Brazil; Bolivia relies heavily on natural gas exports as a major source of revenue.

\section{Bolivia}

a. This chapter begins with a contextual explanation of Bolivia's current economic situation to provide the necessary background to ask the central research question concerning how resource nationalism affects energy integration. Next, this chapter explains Bolivia's history during the twentieth century, emphasizing when necessary, central issues of the overall dissertation: economic nationalism (to include nationalizations), populism, natural resources, and neoliberal policies. Statistical indicators paint a picture of Bolivia's economic evolution across time. The final section of this chapter provides rudimentary commentary and background concerning integration of Bolivian natural gas markets with neighboring Brazil, setting the stage for the case study.

\section{Brazil}

a. This chapter begins with a contextual explanation of Brazil's twentieth century economic experience to provide the necessary background to ask the central research question concerning how resource nationalism affects energy integration. Next, this chapter explains Brazil's history during the same period, emphasizing when necessary central issues of the overall dissertation: economic nationalism (to include nationalizations), populism, natural resources, neoliberal policies, the historical election of Luiz Inácio "Lula" da Silva, and beyond. Statistical indicators paint a picture of 
Brazil's economic evolution across time. The final section provides rudimentary commentary and background concerning integration of Bolivian natural gas into Brazil, setting the stage for development of the case study.

\section{Resource Nationalism and Energy Integration in Brazil and Bolivia}

a. Using quantitative and qualitative data, this chapter explores the relationship between Bolivia and Brazil in the context of energy relationships and agreements, economic nationalism, and the political systems in each country.

\section{Findings and Conclusions of Dissertation}

a. This chapter explores how the dissertation answers the initial research question. The findings fit into the overall context of twentieth century Latin America economics and politics, as well as nest within more expansive questions on international political economy and export-driven models of development. Why do populist regimes, historically operating under an economic nationalist cum protectionist paradigm, simultaneously pursue policies of economic integration? What is the relationship between resource nationalists and open markets, especially in the hydrocarbons sector? What is the relationship between populists, who are typically resource nationalists, and their decision to choose policies of energy integration? In the case of Bolivia, if the natural gas relationship with Brazil declines or is phased-out completely the country will need to develop new markets or refocus on internal development. In Brazil, the 
concomitant discoveries of major petroleum resources off its south-east coast and an ongoing corruption scandal loom large regarding national development. Despite periods of populist governments in both countries, economic liberalism remains entrenched amid nationalist echoes. 


\section{Appendix}

The below table provides economic indicators, definitions, and rationale behind their inclusion in the dissertation. Although these indicators are considered across both countries in the case study, some are more salient than others because of each countries' different stage of development. Subsequent to the table, timeline, measurements, and conversions provides additional context.

\begin{tabular}{|c|c|c|c|}
\hline Indicator & Definition & Inclusion Rationale & Comments \\
\hline GDP & $\begin{array}{l}\text { Sum of the gross value added by all resident } \\
\text { producers in the country }\end{array}$ & $\begin{array}{l}\text { Demonstrates baseline } \\
\text { economic performance }\end{array}$ & \\
\hline $\begin{array}{l}\text { Trade Balance } \\
\text { as \% GDP }\end{array}$ & $\begin{array}{l}\text { External balance on goods/services is the } \\
\text { export of goods/services minus imports of } \\
\text { goods/services }\end{array}$ & $\begin{array}{l}\text { Demonstrates macro-level } \\
\text { trade relationships over time }\end{array}$ & \\
\hline $\begin{array}{l}\text { External Debt } \\
\text { as \% GNP }\end{array}$ & $\begin{array}{l}\text { Total external debt stocks to gross national } \\
\text { income. }\end{array}$ & $\begin{array}{l}\text { Demonstrates potential } \\
\text { eternal pressures on economy }\end{array}$ & \\
\hline $\begin{array}{l}\text { Capital } \\
\text { Investment as } \\
\% \text { GDP }\end{array}$ & $\begin{array}{l}\text { Outlays on additions to the fixed assets of the } \\
\text { economy plus net change in level of inventory }\end{array}$ & $\begin{array}{l}\text { Indicator of future economic } \\
\text { performance }\end{array}$ & $\begin{array}{l}\text { High number indicates } \\
\text { prospects for long-term } \\
\text { economic growth }\end{array}$ \\
\hline $\begin{array}{l}\text { Economic } \\
\text { Growth }\end{array}$ & $\begin{array}{l}\text { Annual percentage growth rate of GDP (Rate of } \\
\text { Change in Real GDP) }\end{array}$ & $\begin{array}{l}\text { Measures increases \& } \\
\text { decreases in production }\end{array}$ & $\begin{array}{l}5 \% \text { is substantial growth; } 7- \\
8 \% \text { is extraordinary }\end{array}$ \\
\hline $\begin{array}{l}\text { Exports as \% } \\
\text { GDP }\end{array}$ & $\begin{array}{l}\text { Represents value of goods/services provided to } \\
\text { the rest of the world. }\end{array}$ & $\begin{array}{l}\text { Demonstrates integration into } \\
\text { the world economy }\end{array}$ & $\begin{array}{l}\text { Commodity-driven } \\
\text { economies are more } \\
\text { susceptible to prices than } \\
\text { more developed economies }\end{array}$ \\
\hline $\begin{array}{l}\text { GDP Per Capita } \\
\text { (Constant } \\
\text { Dollars) }\end{array}$ & GDP divided by the midyear population & $\begin{array}{l}\text { Directly measures productivity; } \\
\text { indirectly measures living } \\
\text { standards }\end{array}$ & $\begin{array}{l}\text { Mean average eliminates } \\
\text { outliers, possibly skewing } \\
\text { measurement }\end{array}$ \\
\hline Inflation & $\begin{array}{l}\text { Annual percentage change in the cost to the } \\
\text { average consumer of acquiring a basket of } \\
\text { goods/services. }\end{array}$ & $\begin{array}{l}\text { Demonstrates purchasing } \\
\text { power over time }\end{array}$ & $\begin{array}{l}\text { Most countries try to keep } \\
\text { inflation } \sim 2-3 \% \text { year, too low } \\
\text { to cause problems to } \\
\text { households }\end{array}$ \\
\hline FDI \% of GDP & $\begin{array}{l}\text { Net inflows of investment to acquire } 10 \% \text { or } \\
\text { more of voting stock in an enterprise operating } \\
\text { in an economy other than that of the investor }\end{array}$ & $\begin{array}{l}\text { Demonstrates } \\
\text { increase/decrease in foreign } \\
\text { investment }\end{array}$ & \\
\hline $\begin{array}{l}\text { GDP as Share } \\
\text { Agriculture }\end{array}$ & Share of derived from agricultural sector & $\begin{array}{l}\text { Estimates importance of } \\
\text { agriculture in economy relative } \\
\text { to generating national income }\end{array}$ & $\begin{array}{l}\text { Indicator of potential political } \\
\text { leverage it can bring during } \\
\text { competition for water }\end{array}$ \\
\hline $\begin{array}{l}\text { Manufacturing } \\
\text { Value Added }\end{array}$ & Estimate of net output of manufacturing sector & $\begin{array}{l}\text { Indicator of stage industrial } \\
\text { development }\end{array}$ & \\
\hline
\end{tabular}

\section{Energy Timeline: ${ }^{19}$}

1. Coal overtakes biofuel during first decade of nineteenth century

2. Oil overtakes biofuels in the 1950 s

3. Oil overtakes coal in the 1960 s

4. Gas overtakes biofuels in the 1960 s

${ }^{19}$ For a detailed work on natural gas and its place in the historical energy timeline, please see Kolb (2013). 
5. Biofuels now account for less than $10 \%$ of world energy usage

6. Nuclear and hydropower are together even less important than biofuels, and are just over $8 \%$ of total world energy usage

7. Solar and wind power are too slight to be a factor

8. $80 \%$ of energy used today is hydrocarbons, and this $80 \%$ breaks down into: coal, $35 \%$; oil, 37\%; natural gas, $28 \%$.

Measurements:

1. $\mathrm{Btu}^{20}:$ British Thermal Unit

2. Ccf: The volume of 100 cubic feet (cf)

3. M: One thousand

4. MM: One million

5. Mcf: The volume of 1000 cubic feet

6. MMBtu: One million Btu

7. Natural gas is measured by volume (cubic feet), but sold based on heating content (Btu).

\section{Conversions: $:^{21}$}

1. 1 food calorie $=4$ Btu

2. 1 gallon of gasoline $=120,476 \mathrm{Btu}$

a. $120,476 \mathrm{Btu}=116.2$ cubic feet $(3.29$ cubic meters) of natural gas

b. $\therefore 1$ gallon of gasoline $=116.2$ cubic feet $(3.29$ cubic meters) of natural gas

3. 1 barrel of crude oil $=42$ gallons $=5,717,000 \mathrm{btu}$

4. 1,000 cubic feet of natural gas $=1,037,000 \mathrm{btu}=8.61$ gallons of gasoline

5. On average, the U.S. uses just over one gallon of gasoline per person per day

\footnotetext{
${ }^{20}$ One British Thermal Unit is the energy required to raise one pound of water by one-degree Fahrenheit.

${ }^{21}$ Conversions derived from the U.S. Energy Information Administration website calculator.
} 


\section{Works Cited}

Achen, Christopher H. and Duncan Snidal. "Rational Deterrence Theory and Comparative Case Studies.” World Politics, vol. 41, no. 2, Jan. 1989, pp. 143-169.

Adelman, M.A. The World Petroleum Market. Johns Hopkins University Press. Baltimore. 1972.

Albaverra, Fernando Sanchez. "America Latina y la Busqueda de un Nuevo Energetico Mundial." Nueva Sociedad, vol. 204, Jul./Aug. 2006, pp. 39-49.

Almond, Gabriel A. and Sidney Verba. The Civic Culture: Political Attitudes and Democracy in Five Nations. Princeton University Press. Princeton. 1967.

Auty, Richard M. "Patterns of Rent Extraction and Deployment in Developing Countries: Implications for Governance, Economic Policy, and Performance." Advancing Development: Core Themes in Global Economics, edited by George Mavrotas and Anthony Shorrocks, Palgrave Macmillan, 2007.

Baritaud, Manuel and Dennis Volk. "Seamless Power Markets: Regional Integration of Electricity Markets in IEA Member Countries.” International Energy Agency. 2014.

Battle, Carlos, et al. "The Changing Role of the State in the Expansion of Electricity Supply in Latin America." Energy Policy, vol. 38, no. 11, Nov. 2010, pp. 7152-7160.

Bebbington, Anthony and Jeffery Bury. "Political Ecologies of the Subsoil." Natural Resources, Volume 8; Subterranean Struggles: New Dynamics of Mining, Oil, and Gas in Latin America, edited by Anthony Bebbington and Jeffrey Bury, University of Texas Press, 2013, pp. 1-26.

Bern, Giana. "Investing in Energy: A Primer on the Economics of the Energy Industry." Bloomberg Press. 2011.

Berrios, Ruben, et al. "Explaining Hydrocarbon Nationalization in Latin America: Economics and Political Ideology." Review of International Political Economy, vol. 18, no.5, Oct. 2010, pp. 1-26.

Blanksten, George I. "Political Groups in Latin America." American Political Science Review, vol. 53, no. 1, Mar. 1959, pp. 106-127.

Breton, Albert. "The Economics of Nationalism." The Journal of Political Economy, vol. 72, no. 4, Aug. 1964, pp. 376-386.

Brunet, Alexia and Juan Augustin Lentini. "Arbitration of International Oil, Gas, and Energy Disputes in Latin America." Northwestern Journal of International Law and Business, vol. 27, no. 3, Spring 2007, pp. 591-630.

Click, Reid and Robert Weiner. "Resource Nationalism Meets the Market: Political Risk and the Value of Petroleum Reserves." Journal of International Business Studies, vol. 41, no. 5, Jun. 2010, pp. 783-803. 
Collier, Paul. "The Bottom Billion.” Oxford University Press. Oxford. 2007.

Conniff, Michael L. "Latin American Populism in Comparative Perspective." University of New Mexico Press. Albuquerque. 1982.

Cooney, Paul. "The Decline of Neoliberalism and the Role of Social Movements in Latin America." Paper presented at the $X$ Journadas de Economia Critica, Alternativas al Capitalismo? Barcelona, Spain, March 23-25, 2006.

Cupolo, Marco. "Public Administration, Oil Rent, and Legitimacy Crises in Venezuela." Reinventing Legitimacy, Democracy, and Political Change in Venezuela, edited by Damarys Canache and Michael R. Kulischeck, Greenwood Press, 1998, pp. 99-112.

Demmers, Jolle et al. "Preface." Miraculous Metamorphoses: The Neoliberalization of Latin American Populism, edited by Jolle Demmers, Alex E. Fernandez, and Barbara Hogenboom, Zed Books, 2000.

Di Tella, Torcuato S. "Populism into the Twenty-First Century." Government and Opposition, vol. 32, no. 2, Apr. 1997, pp. 187-200.

Downey, Morgan. “Oil 101.” Wooden Table Press. 2009.

Edwards, Jack K. and Werner Baer. "The State and the Private Sector in Latin America: Reflections on the Past, the Present, and the Future." The Quarterly Review of Economics and Finance, vol. 33, no. 1, 1993, pp. 9-19.

Frankel, P.H. "Essentials of Petroleum: A Key to Oil Economics.” London. 1969.

Frankel, Jeffrey. "The National Resource Curse: A Survey.” Discussion paper 2010-21, Cambridge, Mass, Harvard Environmental Economics Program, Sep. 2010.

Geddes, Barbara. "How the Cases You Choose Affect the Answers You Get: Selection Bias in Comparative Politics." Political Analysis, vol. 2, 1990, pp. 131-150.

George, Alexander L. "Case Studies and Theory Development: The Method of Structured, Focused Comparison." Diplomacy: New Approaches in History, Theory and Policy, edited by Paul G. Lauren, Free Press, 1979, pp. 43-68.

Ghosh, Pradip. "Developing Latin America: A Modernization Perspective.” Greenwood Press. Westport. 1984.

Glab, Edward. "Changing Global Energy Markets and the Impact on the Americas." Perspectives on the Americas Series. University of Miami. 2015.

Graetz, Michael J. "The End of Energy: The Unmaking of America's Environment, Security, and Independence.” MIT Press. Cambridge. 2011.

Hartley, Peter and Kenneth B. Medlock III. "A Model of the Operation and Development of a National Oil Company." Energy Economics, vol. 30, no. 5, Sep. 2008, pp. 24592485. 
Hartshorn, J.E. "Oil Companies and Governments: An Account of the International Oil Industry in its Political Environment." Faber. London. 1962.

Hindery, Derrick. "From Enron to Evo: Pipeline Politics, Global Environmentalism, and Indigenous Rights in Bolivia." University of Arizona Press. Tucson. 2013.

Honty, Gerardo. "Energia en Sudamerica: Una Interconexion que No Integra." Nueva Sociedad, vol. 204, Jul./Aug. 2006, pp. 119-135.

Ingram, George M. "Expropriation of U.S. Property in South America: Nationalization of Oil and Copper Companies in Peru, Bolivia, and Chile." Praeger Publishers. New York. 1974.

"World Investment Outlook." International Energy Agency. 2014.

Jaffe, Amy Myers. "The Americas, Not the Middle-east, will be the World Capital of Energy." Foreign Policy, Sep./Oct. 2011, pp. 86-95.

Johnson, Harry G. "A Theoretical Model of Economic Nationalism in New and Developing States." Economic Nationalism in Old and New States, edited by Harry G. Johnson, University of Chicago Press, 1967, pp. 1-16.

Katzenstein, Peter. "Between Power and Plenty: Foreign Economic Policies of Advanced Industrial States.” University of Wisconsin Press. Madison. 1978.

Kaufman, Robert R. and Barbara Stallings. "Debt and Democracy in Latin America." Westview Press. Boulder. 1989.

Kennedy, Michael. "An Economic Model of the World Oil Market." The Bell Journal of Economics and Management Science, vol. 5, no. 2, Autumn 1974, pp. 540-577.

Klare, Michael T. and Cynthia Arnson. "Supplying Repression: U.S. Support for Authoritarian Regimes Abroad.” Institute for Policy Studies. Washington. 1981.

Klare, Michael. "Resource Wars: The New Landscape of Global Conflict.” Metropolitan Books. New York. 2001.

Klare, Michael T. “Blood and Oil.” Metropolitan Books. New York. 2004.

Klare, Michael and Daniel Volman. "America, China \& the Scramble for Africa's Oil." Review of African Political Economy, vol. 33, no. 108, 2006, pp. 33:108.

Klare, Michael. "The Race for What's Left: The Global Scramble for the World's Last Resources." Metropolitan Books. New York. 2012.

Kobrin, Stephen. "Political Risk: A Review and Reconsideration." Journal of International Business Studies, vol. 10, no. 1, Spring/Summer 1979, pp. 67-80.

Krueger, Anne O. "The Political Economy of the Rent-Seeking Society." The American Economic Review, vol. 64, no. 3, Jun. 1974, pp. 291-303. 
Kuczynski, Pedro-Pablo and John Williamson. "After the Washington Consensus:

Restarting Growth and Reform in Latin America. Institute for International Economics. Washington. 2003.

Laserna, Roberto, et al. “La Trampa del Rentismo.” Fundacion Milenio. 2006.

Laserna, Roberto. "Mire, La Democracia Boliviana en Los Hechos..." Latin American

Research Review, vol. 45, 2010, pp. 27-58.

Leon, Jose Ignacio Moreno. "El Capital Social: Nueva Vision del Desarrollo."

Universidad Metropolitana, Centro de Estudios Latinoamericanos. 2004.

Li, Raymond, et al, “International Natural Gas Market Integration.” The Energy Journal, vol. 35, no. 4, Oct. 2014, pp. 159-179.

Lijphart, A. "Comparative Politics and the Comparative Method." The American

Political Science Review, vol. 65, no. 3, Sep. 1971, pp. 682-693.

Linkhor, Rolf. "La Politica Energetica Latinoamericana: Entre el Estado y el Mercado." Nueva Sociedad, vol. 204, Jul./Aug. 2006, pp. 90-103.

Macridis, R. and Cox, R. "Seminar Report." The American Political Science Review, vol. 47, no. 3, Sep. 1953, pp. 641-657.

Madrid, Raul. "The Rise of Ethnopopulism in Latin America." World Politics, vol. 60, 2008, pp. 475-508.

Mares, David R. "Resource Nationalism and Energy Security in Latin America:

Implications for Global Oil Supplies.” Working paper: James A. Baker III Institute for Public Policy, Rice University, 2010.

Mares, David and Matin, Jeremy. "Regional Energy Integration in Latin America: Lessons from Chile's Experience with Natural Gas. Third World Quarterly, vol. 33, no. 1, 2011, pp. 55-70.

Martin, Michael Rheta. "Encyclopedia of Latin-American History." Bobbs-Merril. 1968.

Martz, John D. "The Place of Latin America in the Study of Comparative Politics." The Journal of Politics, vol. 28, vol. 1, Feb 1966, pp. 57-80.

Mayorga, Rene Antonio. "Outsiders and Populism: The Road to Plebiscitarian Authoritarianism." Conference on Crisis of Democratic Representation in the Andes, Kellogg Institute for International Affairs, May 13-14, 2002, University of Notre Dame.

McQuaid, Kristina and Steven Otillar. "Recent Developments in Brazil's Oil and Gas Industry: Brazil Appears to be Stemming the Tide of Resource Nationalism." Houston Journal of International Law, vol. 30, no. 2, 2008, pp. 259-287.

Moyo, Sam and Paris Yeros. "Reclaiming the Nation: The Return of the National Question in Africa, Asia, and Latin America.” Pluto Press. New York. 2014. 
Nivola, Pietro S and Erin E. R. Carter. "Making Sense of "Energy Independence."” Energy Security: Politics, Strategies, and Implications, edited by Carlos Pascual and Jonathan Elkind, Brookings Institution Press, 2010, pp. 105-118.

Nowell, Gregory P. “Mercantile States and the World Oil Cartel, 1900-1939.” Cornell University Press. Ithaca. 1994.

Ochoa, Camila, et al. "Simulating Power Integration in Latin America to Assess Challenges, Opportunities, and Threats.” Energy Policy, vol. 61, Oct. 2013, pp. 267-273.

Painter, David S. "Oil and the American Century." Journal of American History, vol. 99, no. 1, Jun. 2012, pp. 24-39.

Panizza, Francisco. "Contemporary Latin America: Development and Democracy beyond the Washington Consensus.” Zed Books. 2009.

Pardo, Claudia and Belizza Ruiz. "Energy Context in Latin America." Energy, vol. 40, no. 1, Apr. 2012, pp. 39-46.

Pascual, Carlos and Evie Zambetakis. "Geopolitics of Energy: From Security to Survival.” Energy Security: Politics, Strategies, and Implications, edited by Carlos Pascual and Jonathan Elkind, Brookings Institution Press, 2010, pp. 9-36.

Paz, Antolin, et al. "How Important are National Companies for Oil and Gas Sector Performance? Lessons from the Bolivia and Brazil Case Studies." Energy Policy, vol. 61, Oct. 2013, pp.707-716.

Perreault, Tom. "Nature and Nation: Hydrocarbons, Governance, and the Territorial Logics of 'Resource Nationalism' in Bolivia." Natural Resources, Volume 8;

Subterranean Struggles: New Dynamics of Mining, Oil, and Gas in Latin America, edited by Anthony Bebbington and Jeffrey Bury, University of Texas Press, 2013, pp. 67-90.

Petras, James. "Social Movements and Alliance-Building in Latin America." The Journal of Peasant Studies, vol. 35. No. 3, Oct. 2008, pp. 476-528.

Phillip, George. "Oil and Politics in Latin America: Nationalist Movements and State Companies.” Cambridge University Press. Cambridge. 1982.

Phillip, George. "Political Economy of International Oil." Edinburgh University Press. Edinburgh. 1994.

Porta, Fernando. "La Integracion Sudamericana en Perspectiva. Problemas y Dilemas." Comision Economica para America Latina y el Caribe. Santiago de Chile. September 2008.

Posner, Richard. "Theories of Economic Regulation." The Bell Journal of Economics and Management Science, vol. 5, no. 2, Autumn 1974, pp. 335-358.

Posner, Richard. "The Social Costs of Monopoly and Regulation.” Journal of Political Economy, vol. 83, no. 4, Aug. 1975, pp. 807-828. 
Pritzl, Rupert F. J. “Corrupcion y Rentismo en America Latina.” Centro Interdisciplinario de Estudios sobre el Desarrollo. 2000.

Roberts, Kenneth M. "Neoliberalism and the Transformation of Populism in Latin America.” World Politics, vol. 48, no. 1, Oct. 1995, pp. 82-116.

Roberts, Kenneth. "Populism, Political Conflict, and Grass-Roots Organization in Latin America.” Comparative Politics,_vol. 38, no. 2, Jan. 2006, pp. 127-148.

Ruiz-Caro, Ariela. "Puntos de Conflicto de la Cooperacion e Integracion Energetica en America Latina y el Caribe." Comision Economica para America Latina y el Caribe. Santiago de Chile. 2010.

Rustow, Dankwart A. "Modernization and Comparative Politics: Prospects in Research and Theory." Comparative Politics, vol. 1, no. 1, Oct. 1968, pp. 37-51.

Saulniers, Alfred H. "State Companies, Public Policy Perspective." The Oil Business in Latin America: The Early Years, edited by Jon D. Wirth, Beard Books, 2001.

Schuldt, Jurgen and Alberto Acosta. "Petroleo, Rentismo, y Subdesarrollo: Una Maldicion sin Solucion.” Nueva Sociedad, vol. 204, Jul./Aug. 2006, pp. 71-89.

Segal, R. "In Defense of the Comparative Method." Numen, vol. 48, no. 3, 2001, pp. 339-373.

Seligson, Mitchell. "The Rise of Populism and the Left in Latin America." Journal of Democracy, vol. 18, no. 3, Jul. 2007, pp. 81-95.

Smil, Vaclav. "Energy Transitions: History, Requirements, Prospects.” Praeger. Santa Barbara. 2010.

Stevens, Paul. "National Oil Companies and International Oil Companies in the Middleeast: Under the Shadow of Government and the Resource Nationalism Cycle." Journal of World Energy Law and Business, vol. 1, no. 1, 2008, pp. 5-30.

Stigler, George. "Free Riders and Collective Action: An Appendix to Theories of Economic Regulation." The Bell Journal of Economics and Management Science, vol. 5, no. 2, Autumn 1974, pp. 359-365.

Stokes, Doug and Sam Raphael. "Global Energy Security and American Hegemony." Johns Hopkins University Press. Baltimore. 2010.

Taher, Abdulhady Hassan. "Energy: A Global Outlook.” Pergamon Press. Oxford. 1982.

Tavares, Marco Aurelio. "The Role of Natural Gas as an Instrument for the Energy Integration in Latin America.” Power Engineering Society, IEEE General Meeting, Jun. 16, 2005, San Francisco, California, United States of America.

Townsend, Janet. "Poverty and Energy: Natural Resource Nationalism and the Natural Resource Curse.” Regions Magazine, vol. 217, no. 1, 2008, pp 11-12. 
Tullock, Gordon. "The Political Economy of Rent-Seeking." Kluwer Academic Publishing. Boston. 1988.

Tullock, Gordon. “The Economics of Special Privilege and Rent-Seeking.” Kluwer Academic Publishing. Boston. 1989.

Tullock, Gordon. "Public Goods, Redistribution, and Rent-Seeking." The Locke Institute. Northampton. 2005.

Turner, Louis. "Oil Companies in the International System.” The Royal Institute of International Affairs. London. 1978.

United Nations. "General Assembly Resolution 1803 (XVII) Permanent Sovereignty over Natural Resources." United Nations Audiovisual Library of International Law, 1962, pp. $1-3$.

"U.N. General Assembly Resolution on Permanent Sovereignty over Natural Resources." International Legal Materials, vol. 13, no. 1, Jan. 1974, pp. 238-240.

Victor, David G, et al. "Oil and Governance: State Owned Enterprises and the World Energy Supply.” Cambridge University Press. Cambridge. 2012.

Vivoda, Vlado. "Resource Nationalism, Bargaining and International Oil Companies: Challenges and Change in the New Millennium." New Political Economy, vol. 14, no. 4, Nov. 2009, pp.517-534.

Wagner, Jay Paul. "Oil and Gas Operations and Environmental Law in Latin America." Energy and Natural Resources, vol. 16, no. 2, 1998, pp. 153-185.

Walker, Ignacio. “The Three Lefts of Latin America.” Dissent, vol. 55, no. 4, Fall 2008, pp. 5-12.

Walt, Stephen M. “The Renaissance of Security Studies.” International Studies Quarterly, vol. 35, no. 2, pp. 211-239.

Webb, Chris. "Latin America: Sharing a Vision.” Power Engineering International, vol. 16, no. 7, 1 Sep. 2008.

Weede, Erich. "Rent-Seeking or Dependency as Explanations of Why Poor People Stay Poor.” International Sociology, Dec. 1986, pp. 421-441.

Weintraub, Sidney. "Bolivia's Natural Gas Nationalization.” Center for Strategic and International Studies. CSIS: Issues in International Political Economy, no. 77, May 2006.

Wiarda, Howard. The Soul of Latin America: The Cultural and Political Tradition. Yale University Press. London. 2001.

Wilson III, Ernest J. "Review: World Politics and International Energy Markets." International Organizations, vol. 41, no. 1, Winter 1987, pp. 125-149. 
Wilson, Jeffery D. "Understanding Resource Nationalism: Economic Dynamics and Political institutions." Contemporary Politics, vol. 21, no. 4, Feb. 2015, pp. 399-416.

Wirth, John. "Introduction." Latin American Oil Companies and the Politics of Energy, edited by John D. Wirth, University of Nebraska Press, 1985.

Wirth, John. "Introduction." The Oil Business in Latin America: The Early Years, edited by Jon D. Wirth, Beard Books, 2001.

Wolf, Christian. "Does Ownership Matter? The Performance and Efficiency of State Oil vs. Private Oil (1987-2006)." Energy Policy, vol. 37, no. 7, Jul. 2009, pp. 2642-2652.

Wu, Kang. "Energy in Latin America: Production, Consumption, and Future Growth." Praeger. Westport. 1995.

Wu, Kang, et al. "From Upstream to Downstream: Megatrends and Latest Developments in Latin America's Hydrocarbons Sector." East-West Center. U.S. Congress. 1995.

Yergin, Daniel. “The Prize: The Epic Quest for Oil, Money and Power.” Free Press. New York. 1991.

Yergin, Daniel. "Ensuring Energy Security." Foreign Affairs, vol. 85, no. 2, Mar./Apr. 2006, pp. 69-82.

Yergin, Daniel. "The Quest: Energy, Security, and the Remaking of the Modern World." Penguin Press. New York. 2011.

Zilio, Mariana and Marina Recalde. "GDP and Environment Pressure: The Role of Energy in Latin America." Energy Policy, vol. 39, no. 12, Dec. 2011, pp. 7941-7949. 


\section{CHAPTER TWO}

\section{Bolivia: Chapter Abstract}

This chapter begins with a contextual explanation of Bolivia's current economic situation to provide the necessary background to ask the central research question concerning how resource nationalism affects energy integration. Next, this chapter explains Bolivia's history during the twentieth century, emphasizing when necessary, central issues of the overall dissertation: economic nationalism (to include nationalizations), populism, natural resources, and neoliberal policies. Statistical indicators paint a picture of Bolivia's economic evolution across time. The final section of this chapter provides rudimentary commentary and background concerning integration of Bolivian natural gas markets with neighboring Brazil, setting the stage for the case study.

\section{Bolivia: Current Scenario}

In 2018 Bolivia faces a severe decline in revenues attributed to the international decline in the price of oil and other commodities, particularly natural gas. In a country where natural gas comprises roughly $50 \%$ of total exports, such dependency on commodities takes its toll on Gross Domestic Product (GDP) as well as Bolivia's internal and external balances. In 2015, Bolivia’s hydrocarbon exports declined to $\$ 4$ Billion, and then again to \$1.6 Billion during the January to August 2016 time frame. Compared to the same time frame in 2015, this is more than a fifty percent reduction. During 2015, Bolivia experienced a trade deficit, which was the first such deficit in a decade (see Graph 1 below). 


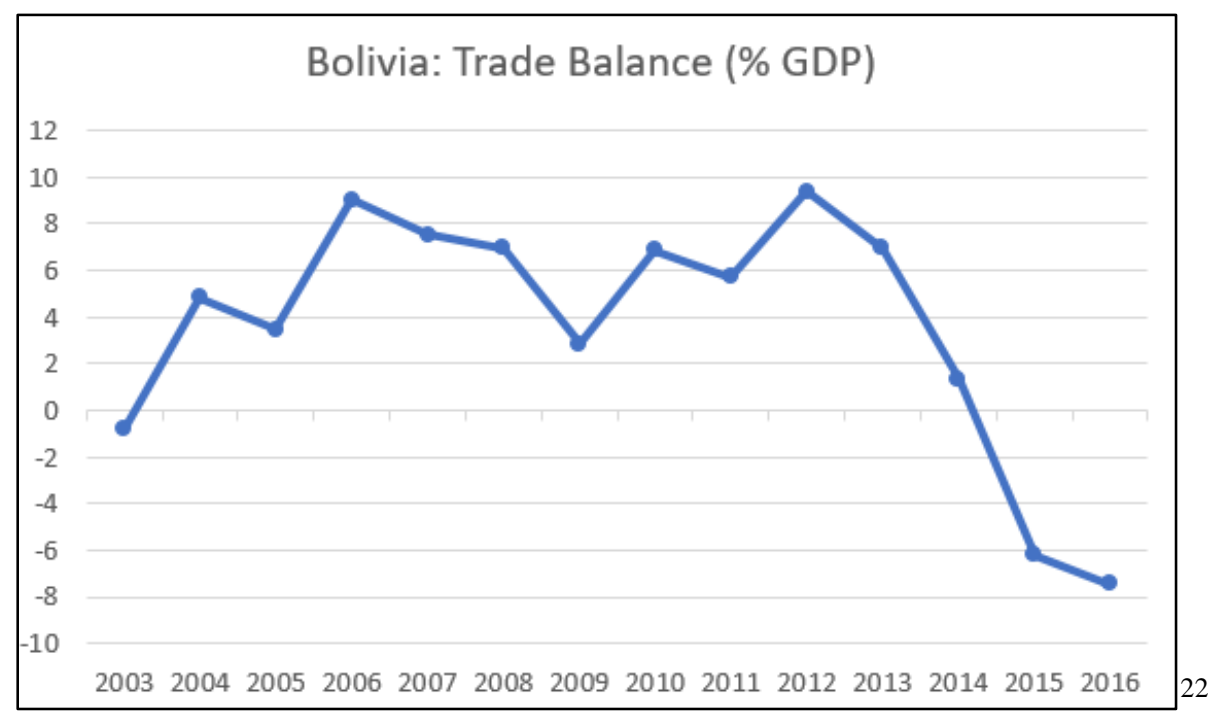

Graph 1: Bolivia Trade Balance (\% GDP)

In early 2016, the Spanish firm Repsol discovered four trillion cubic feet (tcf) of possible natural gas reserves, which could potentially offer Bolivia a forty percent increase in reserves (Ramos 2016). Assuming Repsol begins to exploit these reserves in 2019 as anticipated, the central issue for Bolivia will not be its lack of natural gas for exportation, but where to export if a glut develops. Looming uncertainties relative to the potential drop in the price of natural gas and Bolivia's export relationships create an air of hesitation in the landlocked country.

Over the last decade, Bolivia accumulated its reserves as well as generated a fiscal surplus, at one point reaching \$15 billion. This accumulation allows Bolivia to weather the current economic slowdown in the country (see Graphs 2, 3, and 4 below). Amid this scenario, Bolivia has experienced substantial economic and social progress because of its export revenue. Since 2006, growth has averaged five percent, and poverty has fallen by

\footnotetext{
${ }^{22}$ The Global Economy. http://www.theglobaleconomy.com/. Accessed 14 January 2018.
} 
a third. However, if Bolivia exhausts its savings at the national and local levels, the government will be compelled to cut spending, which can curtail economic growth.

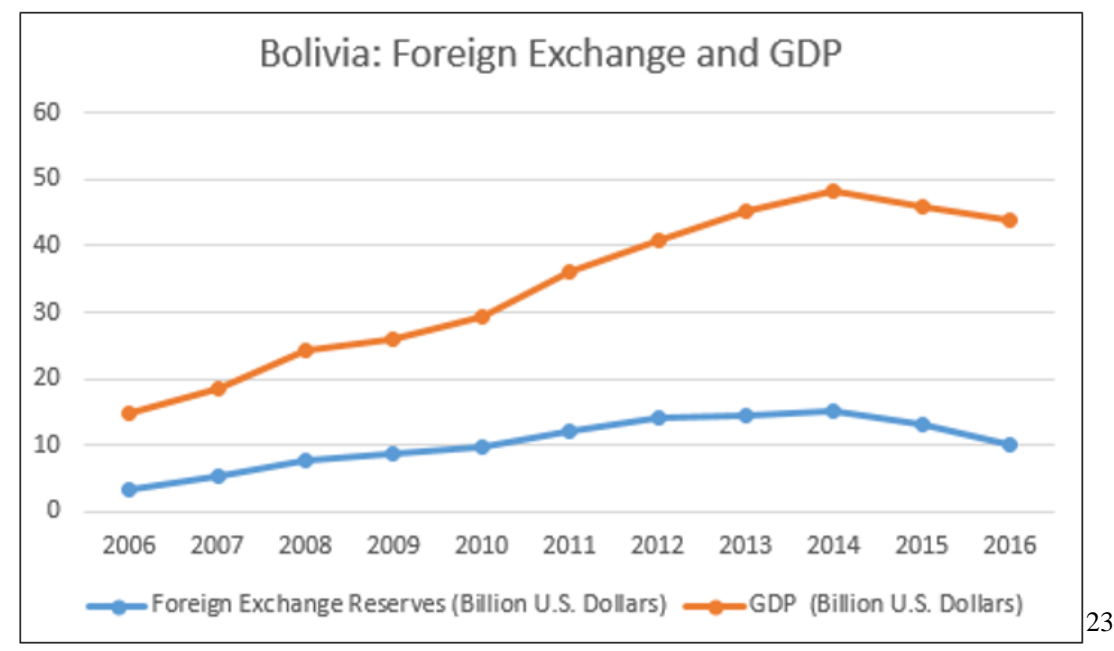

Graph 2: Bolivia Foreign Exchange and GDP

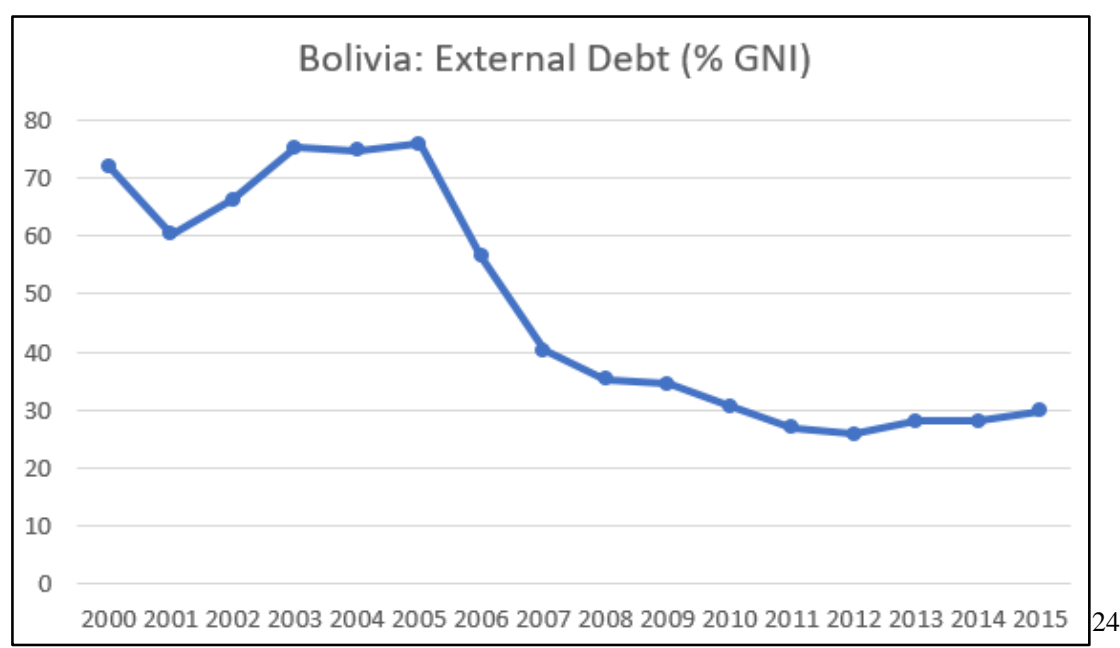

Graph 3: Bolivia External Debt (\% GNI)

${ }^{23}$ The Global Economy. http://www.theglobaleconomy.com/. Accessed 26 May 2018.

${ }^{24}$ The Global Economy. http://www.theglobaleconomy.com/. Accessed 14 January 2018. 


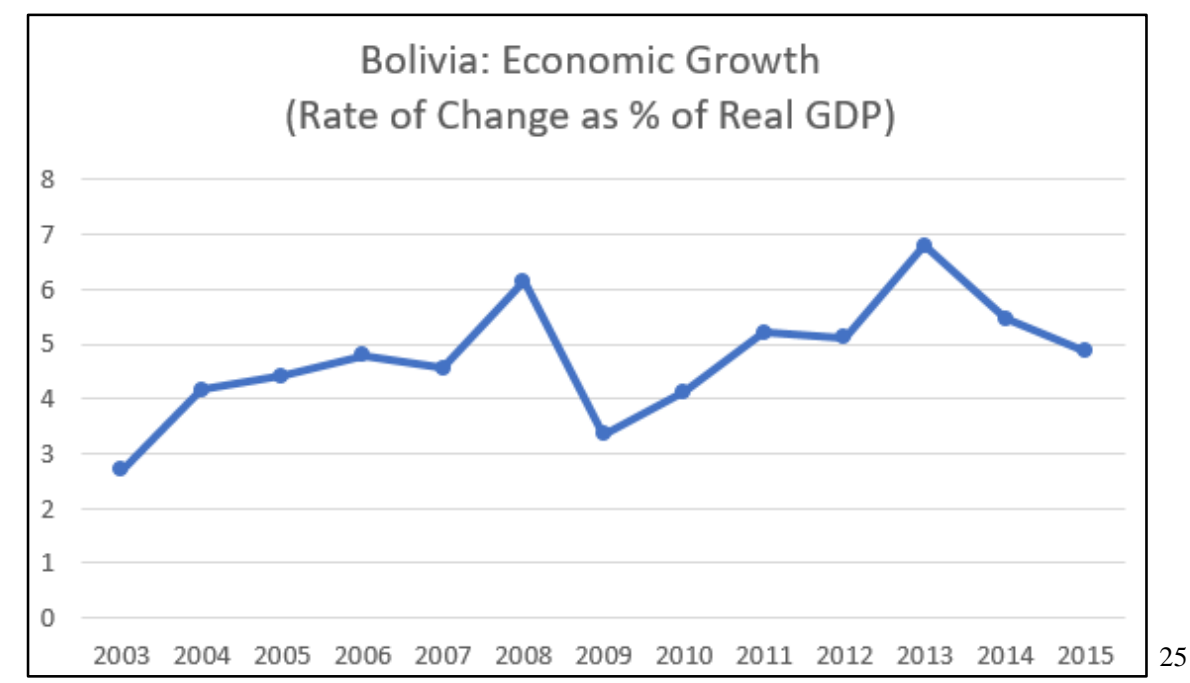

Graph 4: Bolivia Economic Growth

(Rate Change as \% Real GDP)

Bolivia's state oil company, Yacimientos Petrolíferos Fiscales Bolivianos (YPFB), has an agreement with Brazilian parastatal Petróleo Brasileiro S.A. (Petrobras) to deliver 30 million cubic meters of natural gas per day. This contract is set to expire in 2019, and Petrobras recently stated it will reduce the volume of contracted gas. If such a reduction transpires, Bolivia will suffer economically unless it replaces Brazil's Petrobras with another consumer (Petronoticias 2017; Viga 2017). Bolivia appears to have previously considered this scenario in late-2016, when it took mitigating steps in its regional energy integration strategy and pursued new links with Argentina, Paraguay, and Peru. According to Luiz Alberto Sanchez, Bolivia's Minister of Hydrocarbons and Energy, electrical connections, bilateral hydroelectric projects, and increased electricity exports are to be further consolidated in 2017 (Paredes). Such connections are hoped to be a new source of income for Bolivia.

${ }^{25}$ The Global Economy. http://www.theglobaleconomy.com/. Accessed 14 January 2018. 


\section{Bolivia: Markets, Boom-Bust Cycle, and Populism}

\section{Bolivia's Historical Experience:}

The Bolivian disposition towards its natural resources has been forged in a centuries-long crucible of exploitation dating to the Spanish conquest. Resource exploitation in Bolivia dates to the $16^{\text {th }}$ century when the Spanish began mining Potosí for silver (Gamarra 2017). Little of this treasure remained on the continent, and likely even less in Bolivia, as much of this silver wealth accumulated abroad. In the late-19 century, the production of tin had become profitable, and the associated wealth made its way into Bolivian politics; over time, the state became a central source of employment, particularly for the urban middle-class (Malloy and Gamarra 1988, 6). Even prior to the twentieth century, resource wealth and accompanying attempts at resource control were inextricably linked to Bolivian political culture (Gamarra 2017).

The stability of the late nineteenth and early twentieth century Bolivia was predicated on the passivity or non-involvement of most of the population. This period was one of general economic and political stability because of the social mobility afforded to the citizens who were not excluded from the system. Simply put, the Bolivian system was an elitist one in which the base of political power was under the monopoly of the monied and educated, all of which centered on the middle and upper classes (Malloy 1970, 34).

The silver magnates from the latter half of the nineteenth century used their financial power to enter politics. Contrarily, the tin magnates emerging in the late 1800s were largely foreign; this group sought to influence public policy without direct entry 
into political life. The "Big Three" tin tycoons, consolidated power and incorporated their firms outside of Bolivia. Carlos Aramayo, Simon Patiño, and Mauricio Hochschild formed part of the national bourgeoisie known as "La Rosca" (translated in this context as "The Screw"). They operated as pure capitalist entrepreneurs who were interested in private political power instead of its public form. Their interests in Bolivia centered around what would further their own interests. From roughly the 1880s through the late1920s, Bolivians interested in public office would only rise if they were of use to one of the private tin firms (Malloy 1970, 36).

The consolidation of the tin industry essentially controlled the productive base of the Bolivian economy as well as its monetary wealth. When foreign loans were unobtainable, the government turned to the magnates, thus further increasing the reliance of the former on the latter. However, during the 1920s, an incipient labor movement began to push for labor, wage, and other benefits, which resulted in an increasingly unstable political environment (Malloy 1970, 43).

From the late 1920s onward, there was increasing contact between labor and leftist intellectuals, which increasingly pressed demands against a national elite unwilling to cede changes to the economic or political order. This combined with other problems in Bolivia (skewed development; exhaustion of the tin industry; abated development drive), which called into question the ability of the system to adapt (Malloy 1970, 57).

What is important to understand during this turbulent period is that Bolivia's economic expansions and contractions closely shadow the movements in world market prices of silver, tin, and later petroleum (Sachs and Morales 1990, 161). Essentially, during boom times Bolivia had access to foreign loans, which disappeared during 
economic busts. As Bolivian tin lodes were increasingly exhausted in the 1920s, Bolivia began to lose competitiveness with other countries, and the subsequent worldwide economic depression caused Bolivia to default on its sovereign foreign debt (Sachs and Morales 1990, 163). The collapse of tin undermined the economy, as well as the political system, and ultimately ushered in the 1952 Nationalist Revolutionary Movement (MNR) Revolution.

The 1952 MNR revolution in Bolivia was one where the U.S. provided early and continuous support. The MNR revolution in Bolivia was not communist, which factored greatly in U.S. backing. Instead, the MNR revolution was nationalist and antiimperialist, and its energy focused against the tin barons that controlled Bolivia's chief industry, its major source of foreign exchange. The MNR held the barons responsible for the malaise of the entire society. It was La Rosca that was held in contempt as this group controlled both the cities and the government. (Blasier 1972, 55).

The aim of the MNR was to bring down La Rosca by gaining control of the government and its tin mines. The MNR did not aim at the U.S. or European corporations, but Bolivia's exploitative, corrupt, and outdated social system. That Bolivia's tin ore exports were so scattered also did not help the MNR to target one central market. It was the system that felt the brunt of national resentment against ruling groups in Bolivia who were blamed for the disastrous Chaco War discussed later in this chapter (Blasier 1972, 56).

The U.S. ultimately recognized the 1952 MNR government and proposed a longterm plan to collaborate with Bolivia. The U.S. Department of State was confident the MNR was neither communist, nor pro-Soviet. This confidence prepared the countries for 
a close and friendly relationship. The resultant U.S. funding was to develop Bolivia's economy and its natural resources, as well as to expand tin output (Blasier 1971, 73).

The Bolivian case is one requiring closer investigation, and one carried out in the context of regional power relationships. It is unfruitful to look at Bolivia in a vacuum. The U.S. and its foreign policy, to include its development policy, had a palpable impact on $20^{\text {th }}$ century Bolivia. Arguably, the whims of international commodities markets pervade this relationship, and no country can completely ignore these currents; however, countries vary in their ability to withstand or influence these same markets. To impress upon the reader the focus of this study, some historical context is required in both the Bolivia and Brazil chapters. Although both countries engage with the U.S., the nature of each engagement is unique.

Bolivia could be considered a test case in nation-building for the U.S., and the former's relationship with the latter is imperative to examine for any student of the developing world. In the case of Bolivia after the 1952 Revolution, instead of using direct physical force the U.S. increasingly leveraged its economic weight to influence the region. Potential economic stagnation in Bolivia and concomitant political chaos were the deciding factors in the U.S. decision to attempt to influence Bolivia. To understand the U.S.-Bolivia relationship during this period is at the heart of this dissertation, namely through the lens of economic nationalism which requires some inclusion of U.S. responses to such policies.

In the middle-1950s, Bolivia faced what it would again face during the 1980's neoliberal period. That situation included economic stabilization programs (i.e. inflation control, cutting wages, reducing public sector employment), which the Bolivian public 
would find painful. These initial actions were a reaction to the sudden drop in the price of tin, which left Bolivia unable to cope with the bust in its recurring boom-bust cycle. Ultimately, U.S. economic influence in the region, particularly in Bolivia, would have a major impact on the latter as well as the relationship between the two countries, from 1952 until the 1990s. The price of commodities, an export-led development model, economic austerity packages, strong nationalism and regionalism, and political instability pervaded Bolivia from before the 1952 Revolution and continue to present day. Because of these overlapping drivers of economic and political action, the Bolivia case is unavoidable in discussions of development, policy, and market integration.

Economic Nationalism in Bolivia: from Standard Oil to Evo Morales:

Few deep studies into the phenomenon of resource nationalism exist. This dissertation fills gaps in the literature, using Latin America as a test case. This chapter explores some of the drivers behind the creation of Bolivia's state oil firm (YPFB), experiences with Standard Oil (1937), the 1952 Revolution and its aftermath, the nationalization of Gulf Oil (1969), capitalization and Petrobras (1990s), the recurring nationalist experience, and the presidency of Evo Morales (2005 - present). Bolivia has repeatedly been shoved to the political left and right as a result of exploitation by international energy firms, the creation of YPFB, the New Economic Policy (modeled on the Washington Consensus), and a recurring resource nationalism. This chapter proceeds mostly chronologically and explains the evolution of writing on Bolivia to include natural resources, nationalism, democratic and military governance, and energy integration in the twentieth century. 
Bolivian politics developed an intimate experience with a boom-bust economic cycle, wholly dependent on international commodities markets. This cycle perpetuated throughout the last two centuries, and was felt again during the early-to-mid twentieth century regarding tin mining. During the period following the Second World War, a worldwide drop in tin prices and associated deterioration of the Bolivian economy resulted in domestic instability, and was a catalyst for the 1952 Revolution.

Economic nationalism in Bolivia is not a recent phenomenon, but has deeper roots dating to the early twentieth century. During this period, Bolivian policies and attempts at pushing economic nationalist actions have come up against some resistance from the U.S. The driving logic of the U.S. at that time believed the only way for Latin America to grow economically, and later politically, was to participate in an economic system in which countries in the region would sell raw materials to the U.S. and use subsequent foreign exchange earnings to industrialize (Siekmeier 2011, 19). However, assuming the potential for economic nationalism to harm U.S. economic interests in the region, unmistakably based on access to natural resources, it is probable the U.S. opposes nationalizations in the region for this very reason. Bolivia formed part and parcel of this overarching U.S. paradigm, but mitigated U.S. policy, on at least one occasion by nationalizing Gulf Oil in 1969.

Economic nationalism was more the rule than the exception in Bolivia in the twentieth century. Prime examples of nationalizations in Bolivia took place in 1937, 1952, and 1969. In 1937 Bolivia nationalized Standard Oil (arguably a consequence of the disastrous Chaco War). The 1952 Revolution resulted in the nationalization of the tin 
mines through the creation of the Mining Corporation of Bolivia (COMIBOL), and later, as aforementioned, the Gulf Oil nationalization in 1969 (Wanderley 2008, 196).

\section{Colonel David Toro, Lieutenant Colonel Germán Busch, and Constitutional Shift:}

After the First World War (WWI), Latin American countries began to break with the liberal-constitutionalism of the $19^{\text {th }}$ century. Countries in the region began to adopt a socialist constitutional position and altered the role of the state regarding the welfare of the citizens, which reflected the decline of liberalism concomitantly alongside the growth of socialist ideas. In Bolivia, a catalyst for action during this period was the Chaco War and its aftermath. ${ }^{26}$ In the case of Bolivia, Lieutenant Colonel Germán Busch made such an attempt (1937-1939) after following in the footsteps of Colonel David Toro (19361937). Busch attempted to create a dictatorship without a political party, but his goals were ultimately frustrated despite his actions leading to the later rise of revolutionary parties (Klein 1967, 171).

The traditional order which the Chaco Generation would destroy had been in place since Bolivia's War of the Pacific with Chile (1879-1884), in which the military was relegated to a professional role, and did not participate in the political life of the country. Debates of that period centered on the nuances of liberal-democratic philosophies, where Bolivia changed its development model, but not its pattern

\footnotetext{
${ }^{26}$ According to Klein (1967), the Chaco War (1932-1935) was a major turning point in the political history of Bolivia. The humiliating defeat by the Paraguayan military during these three years left Bolivians bitter, disillusioned, and looking for answers. Those seeking clarity in this post-war haze would be named the Chaco Generation, who would soon rebel against the traditional political order which had so egregiously failed them and Bolivia.
} 
(Wanderley 2008, 195). Social and economic elites ran the government despite their ideological differences. All of this changed after the reform-bent Chaco veterans allied themselves with the moderate left, and took over the government with the expressed intent to implement what would later be called "military socialism" (Klein 1965, 26). This would result in a shift in the relationship between the state and the people, with the former taking a more positive role in the welfare of the latter. These veterans essentially laid waste to the traditional and inter-class political system of the late- $19^{\text {th }}$ and early- $20^{\text {th }}$ centuries.

The aim of Colonel David Toro was to destroy what he considered the selfserving capitalism rampant in Bolivia, and to restore economic sovereignty. Toro took advantage of a long-standing dispute with Standard Oil and nationalized the U.S. firm in 1937, to include the company's holdings and equipment. Toro's program additionally included social reform at home, an increased state responsibility for the welfare of Bolivian citizens, the reduction of power and monopoly of the mining oligarchy, and a path of economic development and attracting "good" foreign capital (Klein 1965, 36). Despite his failings in the curtailment of the mining interests, Toro successfully called a Constitutional Convention. The convention resulted in a major shift in the relationship between the state and the people, a legacy present in Bolivia today. However, Toro's plan was not enough for Busch. Busch desired a new Bolivia, compelled Toro to resign, and took over as president in July 1937 (Klein 1967, 169).

Busch entered office with little understanding of the military socialist concept, which would never truly crystallize into a workable political plan. Moreover, Busch was quite naïve in the political realm despite being an excellent military officer. Amid this 
confusion, Busch still maintained Toro's idea and continued with the plan for a constitutional convention. This convention would result in the first truly revolutionary constitution since the republican government, and brought together a wild amalgam of Bolivia's political universe comprised of conservatives, the oligarchy, veterans, communists, and the politically inexperienced (Klein 1966, 263).

The Constitutional Convention was heavily influenced by socialism, and central to the resulting 1938 Constitution was the concept of nationalism. During the debates, two major groupings emerged. The Right included some liberals, some clerics, and was heavily based on eastern lowland groups which included some conservatives and antiindigenous regionalists. The Left contained small parties of various orientations, and the Independent Socialist Party (a direct precursor to the MNR). ${ }^{27}$ The new constitution set the tone for future generations and destroyed the classic constitutional and economically liberal charter in Bolivia. A major figure in twentieth century Bolivian politics, Victor Paz Estenssoro argued the only way for Bolivia to operate a radical revolution in the socio-economic sphere was to have a state monopoly over mineral exports. Even Paz Estenssoro understood the left was too weak to take on the strong mining interests, which he considered a superestado, or super-state (Klein 1966, 271).

\footnotetext{
${ }^{27}$ According to Klein, within the Left was a radical majority, which heavily influenced the 1930 Constitution. This group adopted "social constitutionalism" and eliminated the safeguards which limited the government to a passive role (i.e. protecting property rights; protect individual liberties). The framers altered the nature of the constitution to create a more positive role for the state as well as included new social concepts (i.e. State provisions for social and economic welfare; considered property a derivative right granted by the state if it fulfilled a social function; declared rights of labor; and, attempted but failed to achieve full-scale land reform).
} 
Towards the end, Busch began to lose his grip on power as well as reality, as there was a major disconnect between his proclamations and the political situation on the ground. His suicide in August 1939 brought an end to the army's involvement in political reform, but the period of military socialism had lasting effects as it provided inspiration for future regimes. More dangerously, the Toro and Busch period forced traditional parties to renounce compromise while the extreme left gained support among students and workers. This end of national consensus set the stage for the 1952 Bolivian National Revolution.

\section{The 1952 Revolution:}

The 1952 Bolivian Revolution marked an important turning point in Bolivia's history, and is considered one of the great twentieth century revolutions in Latin America, along with Mexico (1910), Cuba (1959), and Nicaragua (1979). This revolution deepened Bolivian democracy, made the society more inclusive, and clearly demonstrated the power of popular action (Whitehead 2008, 269). In this context, it is also important to note Bolivia's role as a pioneer within Latin America: nationalization in the 1930s, accepting a U.S. economic aid program in the 1950s, and undergoing economic "shock treatment" programs of the 1980s.

A completed revolution is one which moves from one political order to another. During this transition, the old order is in question until a new one is established (Malloy 1970). Malloy conceives a revolution as comprised of four dimensions, the most important of which is the redistribution of the capacity of groups to influence a society's authoritative mechanisms. Prior to such a revolutionary situation, there are preconditions 
that include dysfunction, an elite that is either unable or unwilling to enact a solution, as well as the presence of accelerators. Again, referencing Malloy, without accelerators, such as an economic depression or war (particularly losing a war as was the case in Bolivia's Chaco War), revolutionary preconditions may create a revolutionary situation, but are not enough to result in an actual revolution (Malloy 1970, 8). Bolivia entered the twentieth century amid skewed development that centered in one economic sphere, namely mining.

Burke and Malloy (1974) explain that during the post-1929 worldwide depression many reformist movements emerged across Latin America. These movements considered themselves unique in the Latin American experience with the aspirations of solving problems of economic development and social justice in the region in a way that was neither capitalist nor socialist. Bolivia's MNR is one such example of a party that had its roots in the early 1930s. The aims of the MNR at that time were the dual goals of breaking dependence of the Bolivian economy away from the industrial centers of the U.S. and Europe (Burke and Malloy 1974, 49). Such a break would ideally destroy the semi-feudal structure then in place, thereby freeing human and material resources for state-led development. These were the central thrusts of the national populist ideology in Bolivia. The goal was to create state-led development through a national party that transcended elites, foreign interests, and the local oligarchy, that such "anti-nationalists" were believed to serve. To clarify, the difference between Anglo-American development models and those of Latin American countries involve the latter being rooted in traditional Hispanic concepts of fusing state controlled development with modern corporate organization (Wiarda 2001). Here, corporatism is the operating model. 
Christopher Mitchell (1977) partly disagrees with Burke and Malloy’s “national corporatist" argument. Mitchell is quite critical of the MNR and the party's internal divisions. Bolivia was left internationally vulnerable. The root of this vulnerability was the MNR's identification with the middle-class, which converted into a conservative group after the initial revolutionary objectives were met. The 1964 revolution, in Mitchell's opinion, may have been even more middle-class dominant than in 1952. Important here is how the MNR, a progressive and civilian movement, helped form the foundation of a military dictatorship. Ironically, the MNR was born out of earlier disillusionment with the devastating results of Bolivia's involvement in the Chaco War, then evolved into a party that later relied on military force to control an awakened populace to compel change within Bolivia.

The national corporatist argument is exemplified by the creation of the Mining Corporation of Bolivia (COMIBOL), the state-owned mining company. ${ }^{28}$ Miners' power ebbed and flowed relative to the price of commodities. With any drop in tin prices, so would fall the collective bargaining power of organized labor. It is important to note that despite the importance of tin on the world market, prior to the revolutionary period, mining in Bolivia was a nominal source of labor and the country remained overwhelmingly agricultural in its focus.

Malloy and Gamarra (1988) explain Bolivia’s revolution during its later years. Because of the extreme conditions in Bolivia, the country and its associated revolutionary experiences make an excellent case that helps elucidate major dynamics across Latin

\footnotetext{
${ }^{28}$ COMIBOL was formed in 1952 as a direct result of the revolution. Prior to the creation of COMIBOL,
} the tin mining industry was controlled by a group of tin barons, known as "The Rosca." 
America. The military action of 1964 was not counterrevolutionary, but was a period of transition to reorganize the foundational structure of the economy with its roots in the 1952 revolution (Malloy and Gamarra 1988, 202). Ultimately, as the military moved against Victor Paz Estenssoro in 1964, they did so to reclaim the revolution which by then had degenerated into a personalistic and non-ideological amalgam of patronage politics. The military takeover was carried out with support from outside the MNR, demonstrating how far the MNR shifted from its initial stated goals during its collapse. After Paz Estenssoro, General René Barrientos Ortuño took power and the military pushed onto Bolivia a state-capitalist model without the inclusion of a large component of the MNR.

\section{The Era of State Capitalism (1964-1969):}

The Barrientos period was a clear and direct result of the evident failure of the MNR to resolve the inherent contradictions in the 1952 Revolution. The Barrientos regime emerged to reverse the populist capitalist model unleashed by the revolution, and used force to impose the costs of accumulation onto the once-powerful working class. This force was backed by U.S. and international financial actors. The scope of the Barrientos regime demonstrated an increased opening of Bolivia to the international financial system, and concomitantly an increased dependency of the former on the latter (see Graphs 5 and 6, below). During Bolivia's period of state capitalism (1964-1969), tin was the predominant commodity, rarely dropping below $50 \%$ of exports. 


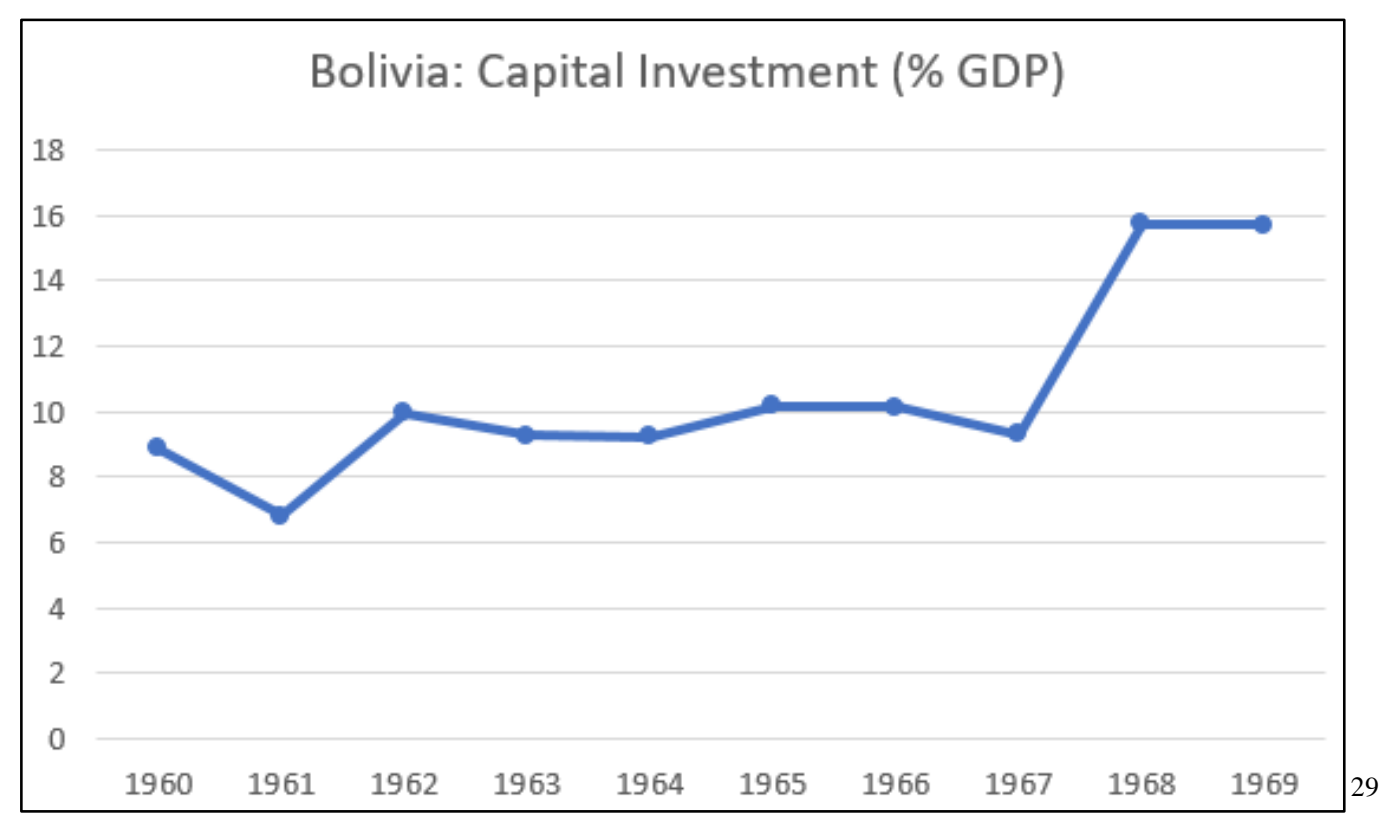

Graph 5: Bolivia Capital Investment (\% GDP)

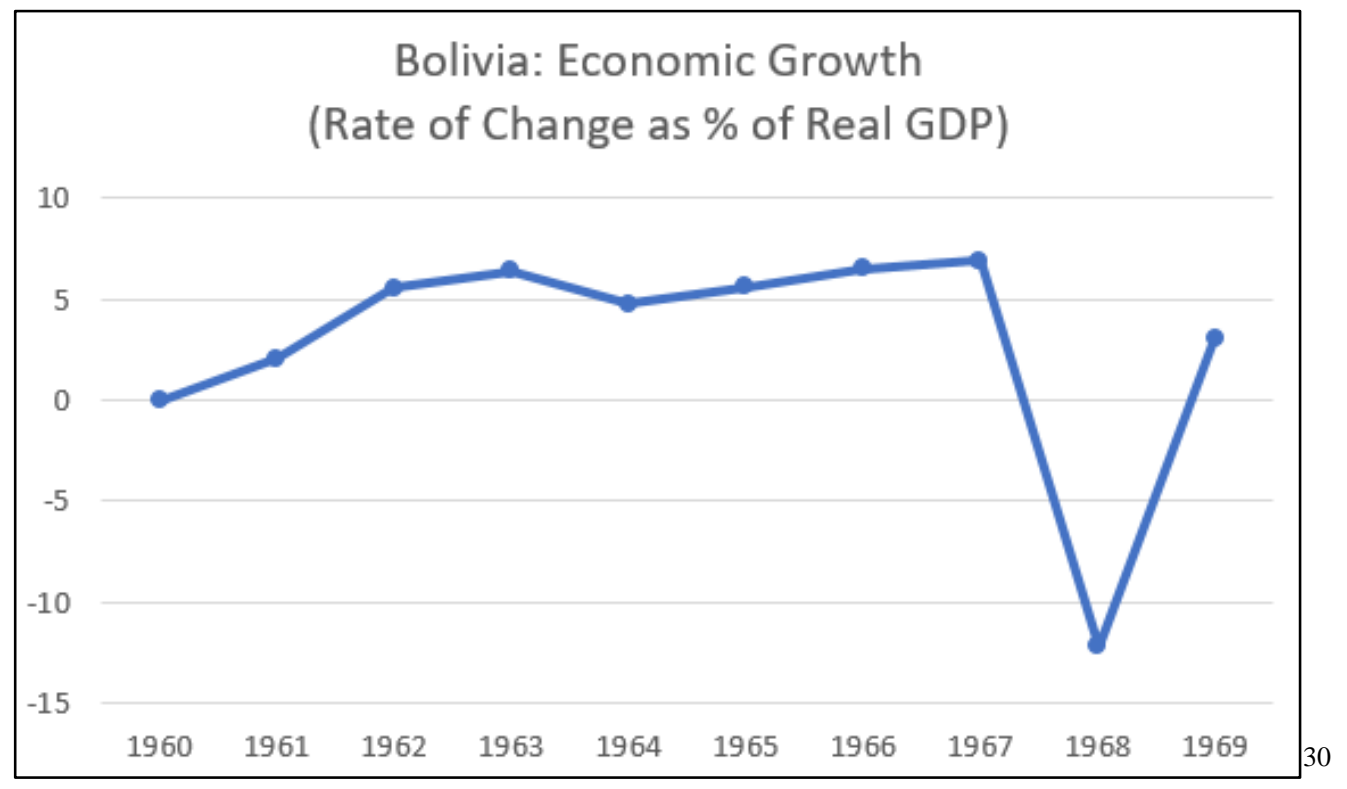

Graph 6: Bolivia Economic Growth

(Rate Change as \% Real GDP)

${ }^{29}$ The Global Economy. http://www.theglobaleconomy.com/. Accessed 14 January 2018.

${ }^{30}$ The Global Economy. http://www.theglobaleconomy.com/. Accessed 14 January 2018. 
To boot, the Barrientos regime was devoid of ideology and vision, mostly defined by the tense relationship between the state and organized labor. This relationship was unnerving and violent as the government attempted to assert its control over labor and to impose a state-centric capitalist development model, with a major shift from a populist to an authoritarian approach (Malloy and Gamarra 1988, 14). This development model was what the MNR and its international backers desired. The MNR's failure to actualize this model brought the military into power.

The case throughout the entire Bolivian experience before and since the 1952 Revolution was the brutal reality of economic scarcity and external economic pressure. These dual forces would tear apart the MNR populist coalition. Under Barrientos, the Bolivian middle-class was largely dependent upon the state for employment and was a product of the country's outward-oriented export model of capitalist dependent development (see Graphs 7, 8, and 9 below). 


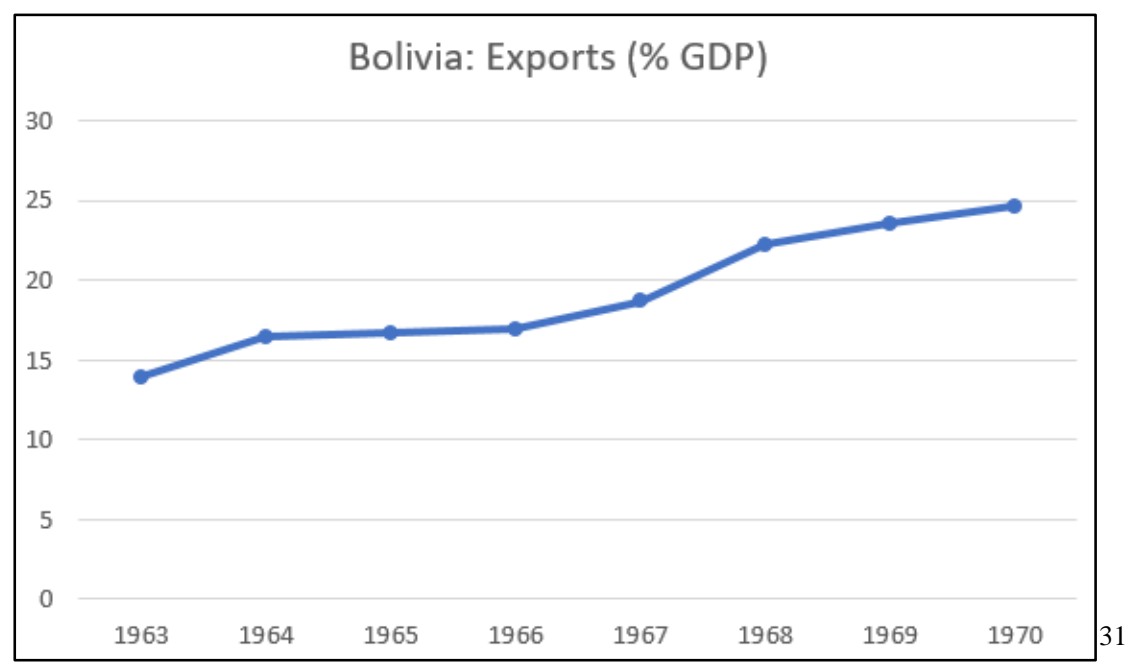

Graph 7: Bolivia Exports (\% GDP)

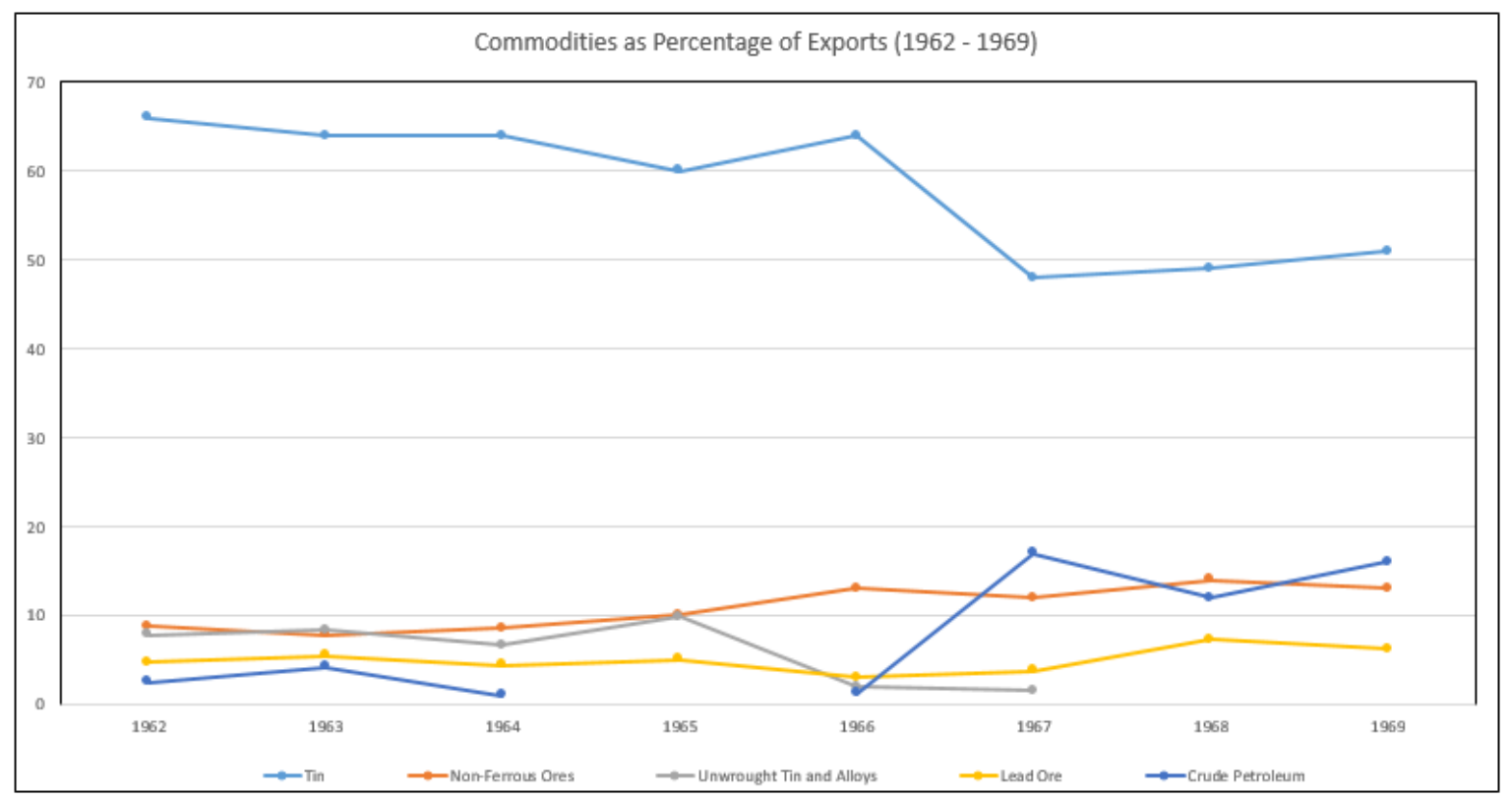

Graph 8: Bolivia Commodities as \% of Exports (1962-1969)

${ }^{31}$ The Global Economy. http://www.theglobaleconomy.com/. Accessed 14 January 2018.

${ }^{32}$ MIT. The Observatory of Economic Complexity. http://atlas.media.mit.edu/en/. Accessed 14 January 2018. 


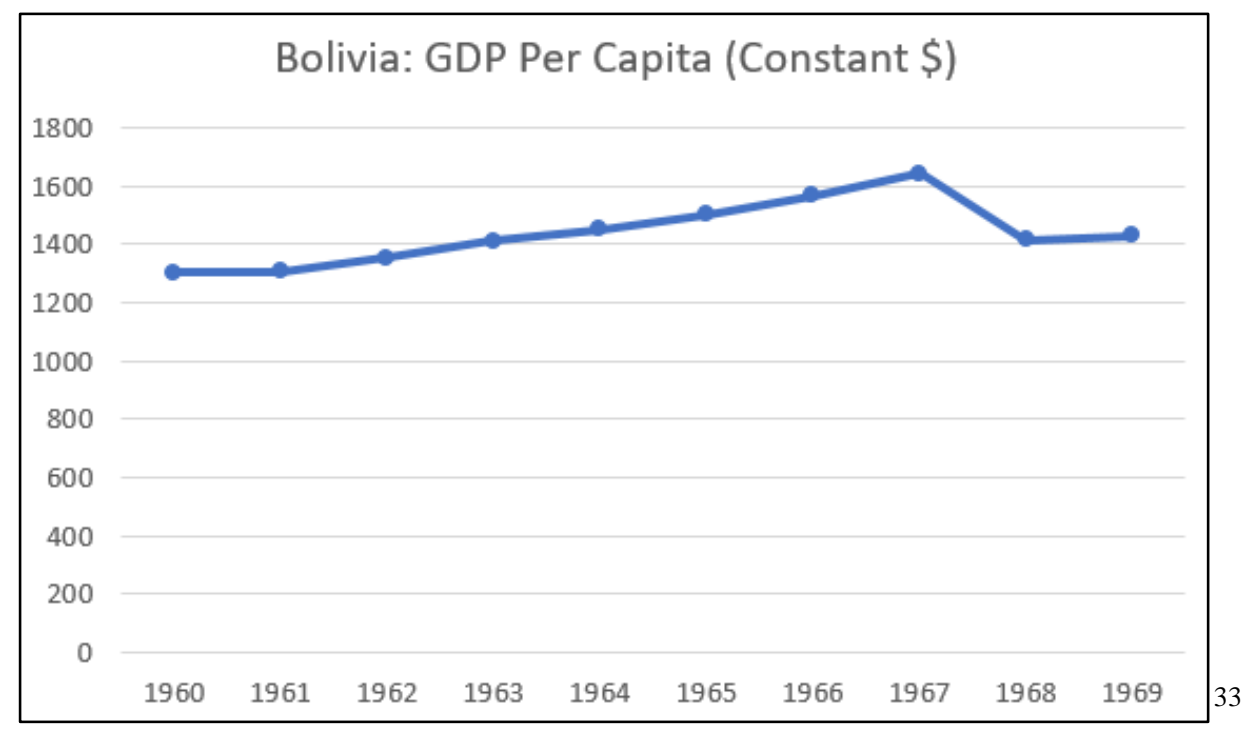

Graph 9: Bolivia GDP Per Capita (Constant \$)

The Barrientos regime rested upon the strength of the peasants and military. However, under the formal alliance (pacto military-campesino), the peasants played an inferior role. This pact had informal roots dating to the 1950s, and was an anti-Left and anti-labor alliance, maintaining the idea that an alliance between the middle-class and peasants was more practical than the one between peasants and the working class that the Left touted. The extent the military was involved in politics gave the appearance, if not already an assumed reality, that it was an armed political party. This argument is based on the numbers of military officers in government posts and in parastatals. However, military involvement in governance also contributed greatly to its undoing as the institution disintegrated and absorbed many of the factional conflicts manifested in Bolivian society at large.

${ }^{33}$ The Global Economy. http://www.theglobaleconomy.com/. Accessed 14 January 2018. 
As the military broke down as an institution, it was no longer able to perform as a coherent force capable of implementing the will of the government. Government policy was equally incoherent. Military factionalization demonstrated that Barrientos was not supported by the military as a whole, but by groups within the organization. Moreover, Barrientos held on to power under a clientelistic distribution of jobs and patronage amid legendary levels of corruption. That corruption in Bolivia existed was not a new phenomenon; however, under Barrientos its scale was enormous, was the primary mode of governing, and flowed directly from the president unmediated by political parties (Malloy and Gamarra 1988, 28). That political parties were almost irrelevant under this system of patronage demonstrates the acute crisis of governance Bolivia faced during this and subsequent periods.

During this period and into the early-1970s the critical area of economic growth was petroleum (see below graph). Barrientos kept this sector open to foreign private investment, and by the middle-1960s, the U.S. corporation Gulf Oil monopolized private petroleum production in Bolivia. Nevertheless, despite Barrientos' investment-favorable policies, little foreign investment ended up in Bolivia between the years 1964-1969, and the regime remained heavily dependent on foreign aid to finance its budget (Malloy and Gamarra 1988, 17). The sudden death of Barrientos in a plane crash in 1969 resulted in yet another rocky political transition as the military High Command stepped in to determine who would enter the presidency. 


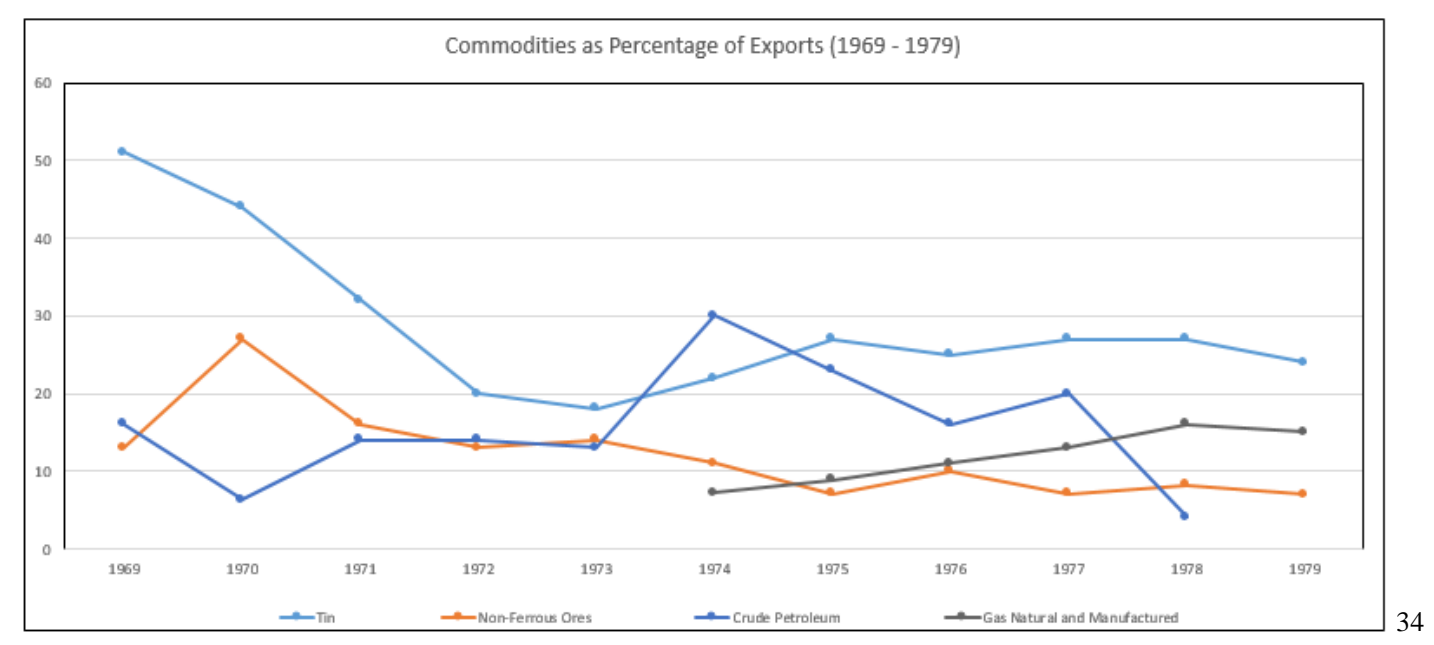

Graph 10: Bolivia Commodities as \% of Exports

(1969-1979)

After Barrientos died, there was an immediate need to fill the resultant power vacuum. General Ovando took the helm of government in September 1969, and one month later nationalized Gulf Oil Corporation. Despite his nationalist efforts and appeals to the populace, Ovando was unable to organize a coherent political party and the military replaced him with General Torres in October 1970. Torres, a radical leftist was equally unable to organize the splintered left (Malloy and Gamarra 1988, 214).

The Bolivian military High Command determined Luis Adolfo Siles Salinas, a social democrat, would enter the presidency and many saw Salinas as an interim leader. General Alfredo Ovando Candía, co-president with Barrientos until the latter's death, openly campaigned for the presidency and in a bloodless coup deposed Salinas in September 1969. Ovando was non-ideological like Barrientos before him, as well as a

${ }^{34}$ MIT. The Observatory of Economic Complexity. http://atlas.media.mit.edu/en/. Accessed 14 January 2018. 
nationalist, and considered the military a necessary tool in national development.

Ovando revived the original state capitalist approach of the 1952 Revolution and placed a renewed emphasis on nationalism, an activist state, as well as populist mobilization. In fact, almost immediately upon entering office, Ovando nationalized Gulf Oil Corporation. That oil, and later gas, were central to the strategic question of Bolivia, as is the case in most states, these "commanding heights" of the economy were naturally of interest to the military (Malloy and Gamarra 1988, 49).

Despite Ovando's populist overtures, by the late-1970s he was clinging to power and relying on the military as the government began to lose its control over Bolivian society. Ovando's top-down approach to populism was ineffective as he lacked authentic ties to the groups he was trying to maneuver. As seen repeatedly since the 1952 Revolution, the lack of authentic links between the government and the governed results in a popular disconnect, thus leading to renewed political instability, usually manifested in public demonstrations, protests, or in historical cases where organized labor was strong, work stoppages and strikes.

General Rogelio Miranda led a coup in October 1970 and negotiated Ovando’s resignation. As the country slid towards a civil war, the military once again stepped in and placed General Juan José Torres González, a leftist, in office. Torres’ tenure was short-lived as he was never an effective president. His administration lacked central authority and was built on a tenuous alliance between the military and the labor left (Malloy and Gamarra 1988, 54).

Shortly after taking office, anti-Torres demonstrations originated in Santa Cruz de la Sierra and were taken over by General Hugo Banzer Suárez. General Banzer 
attempted a coup in January 1971, and failed, only to lead a successful one in August of that same year. Banzer then ushered in what would become a decade of authoritarian military rule. The ensuing rebellion is of note as it was the first to originate outside of $\mathrm{La}$ Paz, and demonstrated the burgeoning importance of Santa Cruz as a power base unto itself, attributable to the associated natural resource wealth in this region. Once in power in August 1971, Banzer moved to crush the labor left and to intimidate the opposition (Malloy and Gamarra 1988, 67).

By early-1971 the power in Bolivia was in the hands of the military (Dunkerley 2017, 295). As a result, social groups sought alliances with the military to press their demands, and the ideologically-divided military began to fracture under the intense pressure of competing interest groups. Military ideological divisions were numerous, but mostly centered on the populist versus anti-populist models of state capitalism. After almost twenty years, Bolivia was still dealing with the fallout from the 1952 Revolution: state-capitalism versus state-socialism, with the former subdivided into populist/antipopulist variants (Malloy and Gamarra 1988,66). From this point until the end of Banzer's dictatorship, amid economic crises, a divided military, and equally fractious social pressures on the government, the central driver behind the presidency had nothing to do with governance, but simply attempts to access power.

Bolivia during the 1970s experienced a string of repressive governments that came into power and promoted free-market policies that threatened the initiatives of Bolivia's earlier revolution (Dunkerley 2017, 296). During the 1970s, the petrodollar boom, a rise in interest rates, and corruption within the military governments all adversely affected Bolivia's ability to navigate this fiscal storm. With Bolivia serving as 
a regional example, at its core the causes of Latin America's "lost decade" of the 1980s had its roots in economic decisions of the 1970s.

Banzer, State Capitalism, and Dictatorship:

From the 1952 MNR Revolution to 1970, just prior to the dictatorship under Banzer, all social groups across Bolivia attempted to influence the struggle. The competition among each social group (military, peasants, organized labor, traditional political parties, emerging parties, etc.) created ideological chaos in the country, particularly within the military. The situation in Bolivia contrasted greatly with the traditional and stable hierarchy in neighboring militaries such as Argentina, Brazil, and Chile. However, despite the personal, political, and factionalized ideological chaos, the Bolivian military never failed to accept the basic tenets of the 1952 Revolution in the economic or political sense, and remained committed to agrarian reform and the mobilization of the peasantry (Klein 1992, 247; Whitehead 2008, 262).

In short, a heavily polarized Bolivia under General Hugo Banzer Suárez witnessed firm rule alongside initial economic growth and aggregate prosperity (see graphs 11-14, below). However, in hindsight, all was not as stable as the macroeconomic indicators appeared. 


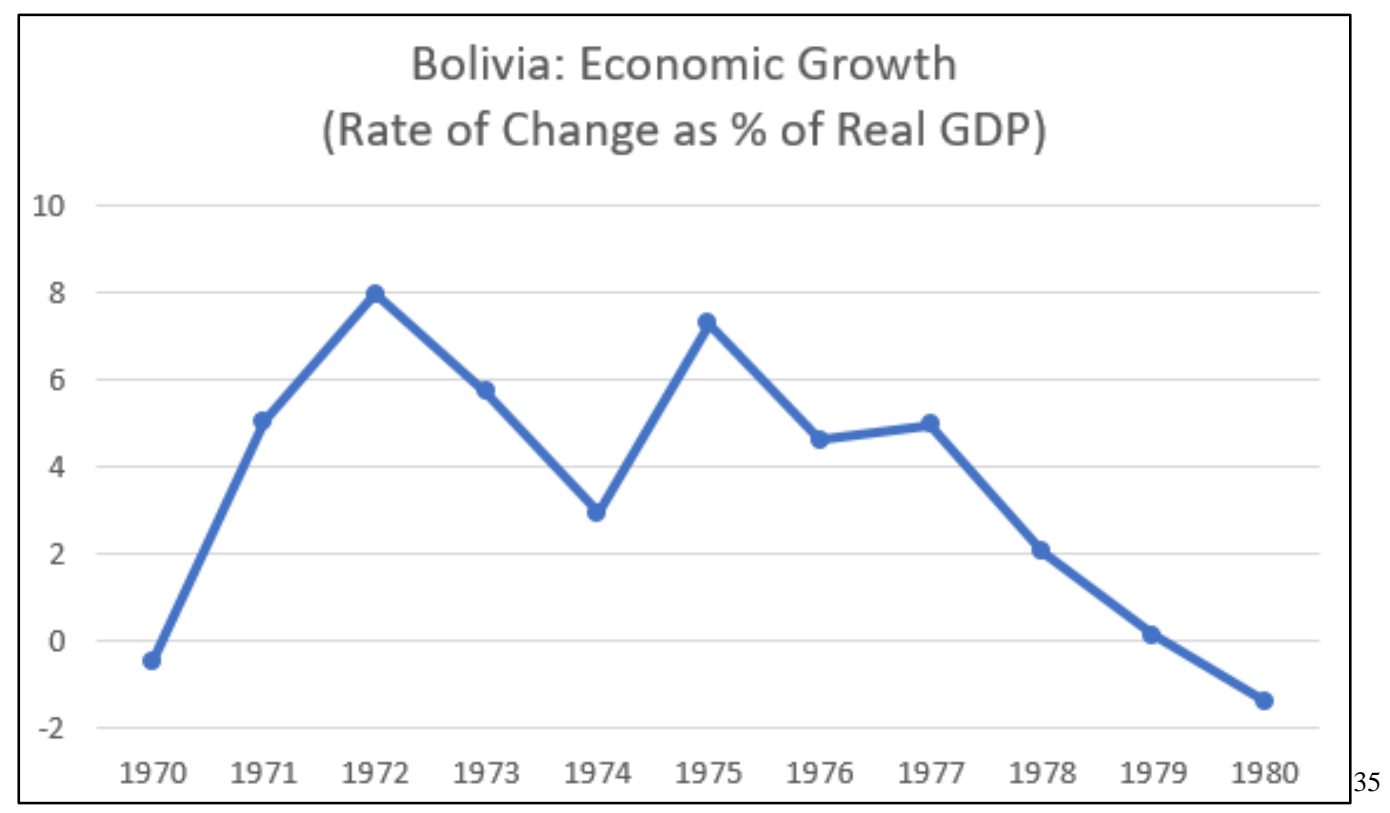

Graph 11: Bolivia Economic Growth

(Rate Change as \% Real GDP)

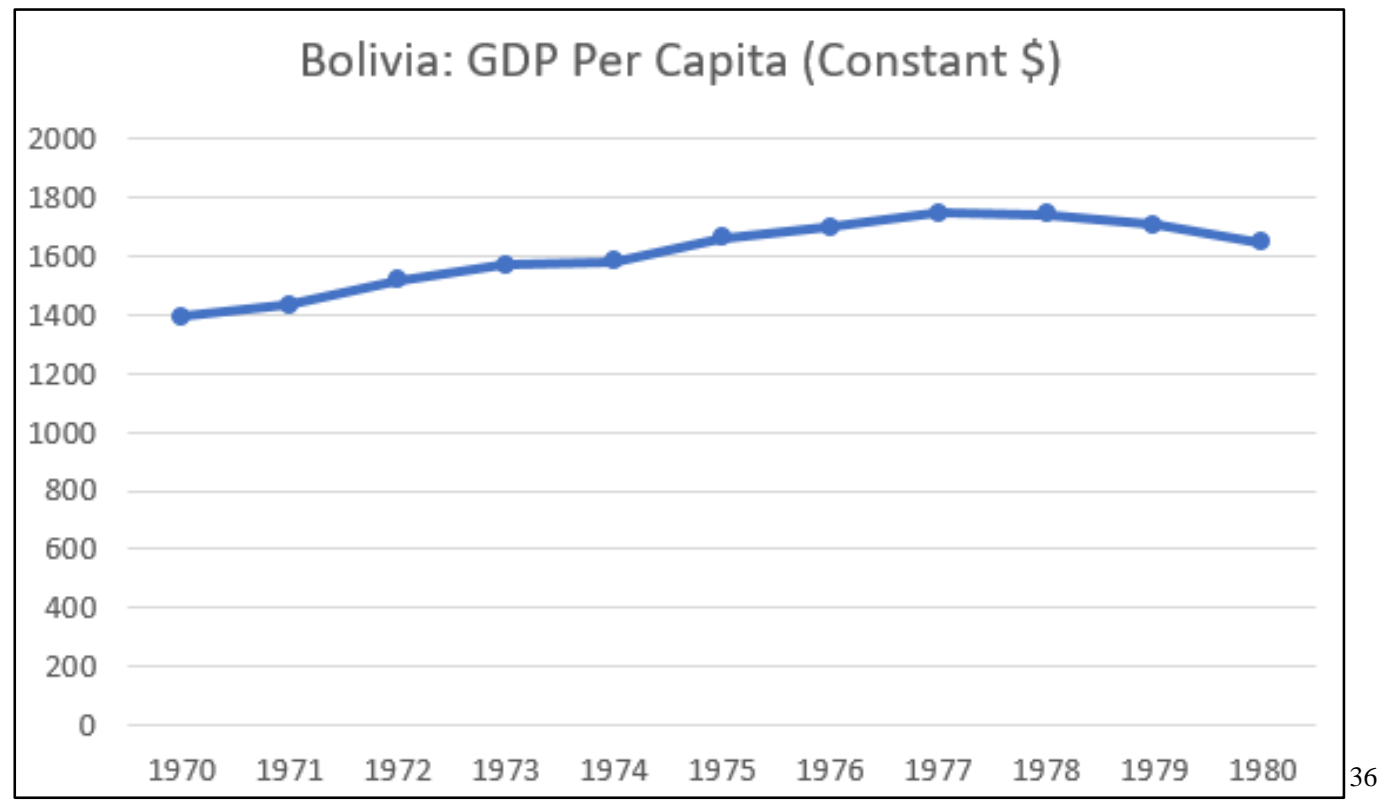

Graph 12: Bolivia GDP Per Capita (Constant \$)

${ }^{35}$ The Global Economy. http://www.theglobaleconomy.com/. Accessed 14 January 2018.

${ }^{36}$ The Global Economy. http://www.theglobaleconomy.com/. Accessed 14 January 2018. 


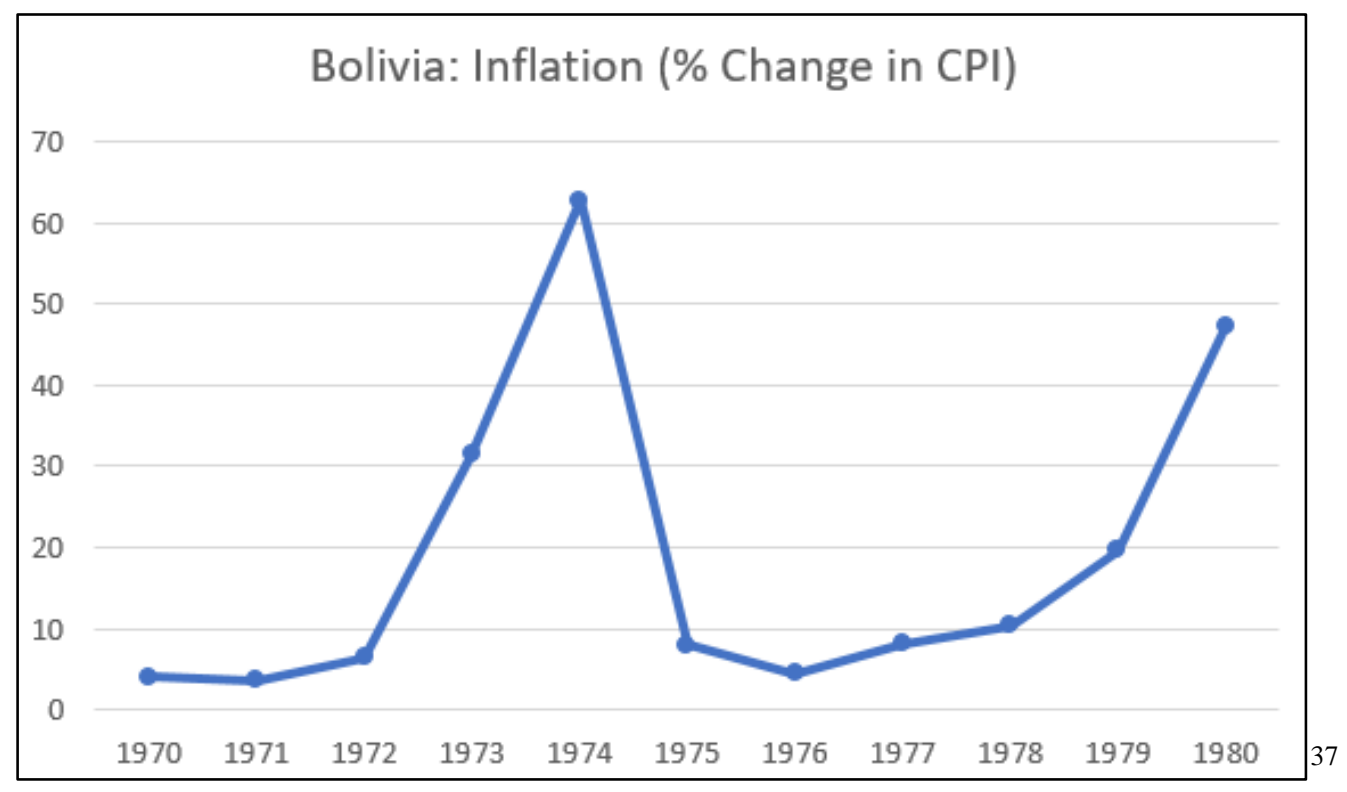

Graph 13: Bolivia Inflation (\% Change in CPI)

${ }^{37}$ The Global Economy. http://www.theglobaleconomy.com/. Accessed 14 January 2018. 


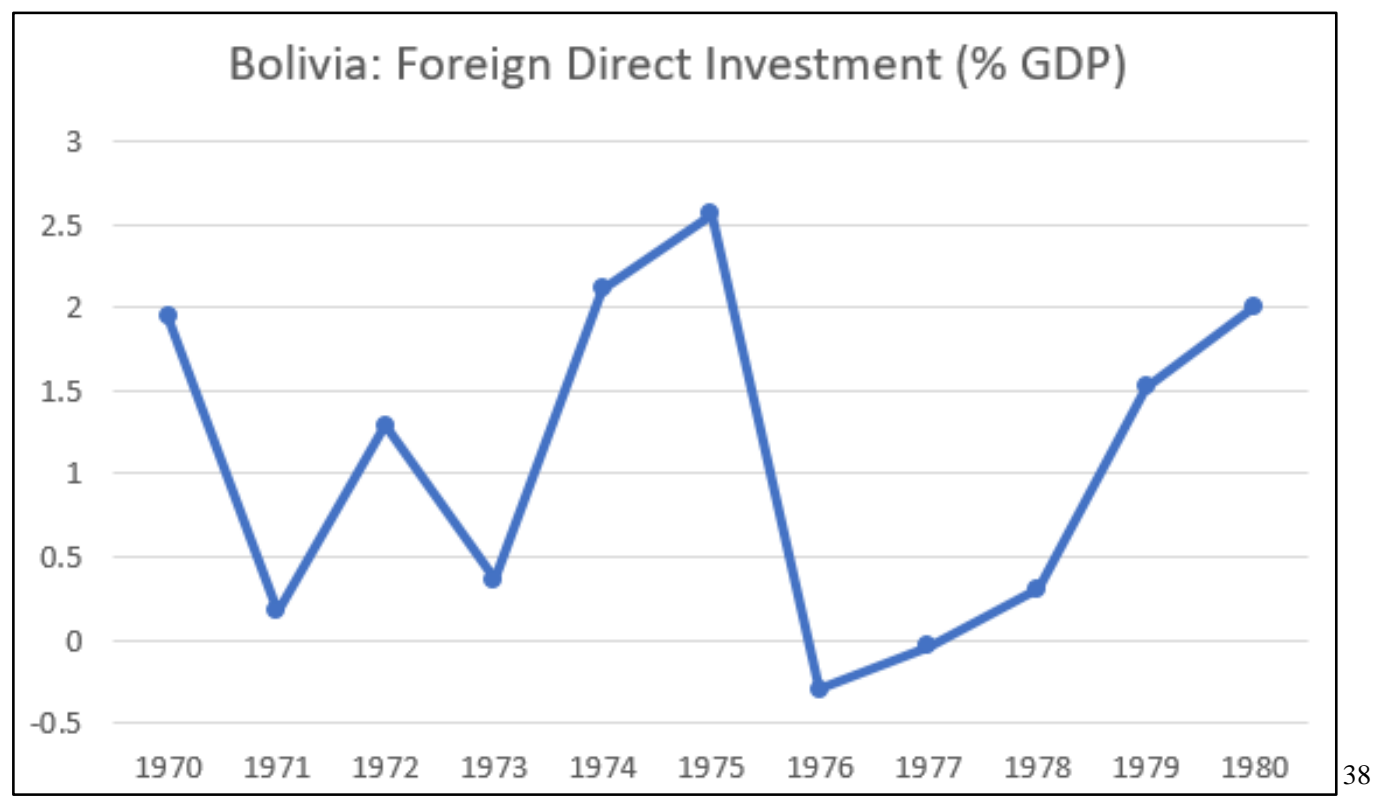

Graph 14: Bolivia Foreign Direct Investment (\% GDP)

Amid economic progress there was concomitant political decline and institutional erosion. Banzer faced constant threats from his own coalition (military; political; private sector independents) and expended much of his energy holding onto power rather than governing (Malloy and Gamarra 1988, 74). Banzer's program was designed to curb popular consumption and generate investment capital, but his actions resulted in a strong negative reaction from the peasants. In turn, there was stronger government repression. This action-reaction cycle became increasingly dangerous.

The result was the disintegration of the historical pacto militar-campesino. In November 1974, the military assumed full political and administrative control over the state and government with the expressed intention of creating a "New Bolivia" (Plan Nuevo Bolivia) based on a centralized and authoritarian concept of state-society relations.

${ }^{38}$ The Global Economy. http://www.theglobaleconomy.com/. Accessed 14 January 2018. 
Plan Nuevo Bolivia was essentially a form of Bureaucratic Authoritarianism (B.A.) that was to usher in and enforce a period of state capitalism: higher government positions were filled by those with experience in large bureaucracies (military; public civil service; large corporations). ${ }^{39}$ B.A. regimes entailed popular political exclusion, popular economic exclusion, and depoliticization (top-down decisions lacking popular sector consultation). In Bolivia, this form of B.A. regime manifested itself through the banning of political parties, the suppression of organized labor, and the reorganization of the civil service (Malloy and Gamarra 1988, 91).

From the beginning, Banzer wanted Bolivia back on a state capitalist development strategy whereby there would be capital accumulation and a shift of resources to modern components of the private and public sectors (i.e. popular economic exclusion). This move was like other countries across Latin America, where the state capitalist model placed the state at the forefront and accompanied the open disciplining of labor. The role of the state became that of primary generator of capital and would mediate the flow of capital (see graph 15, below). The state became the largest source of investment (i.e. infrastructure projects, public corporations, credit policy), as well as entrepreneur and employer (Malloy and Gamarra 1988, 96).

\footnotetext{
${ }^{39}$ Bureaucratic Authoritarianism (B.A.) regimes, as defined by O’Donnell (1978), were a Latin American product of the 1960s (Brazil, then Argentina) which came about because of extended political activation of the popular sector; popular sectors were deemed a threat to other classes and their international links.
} 


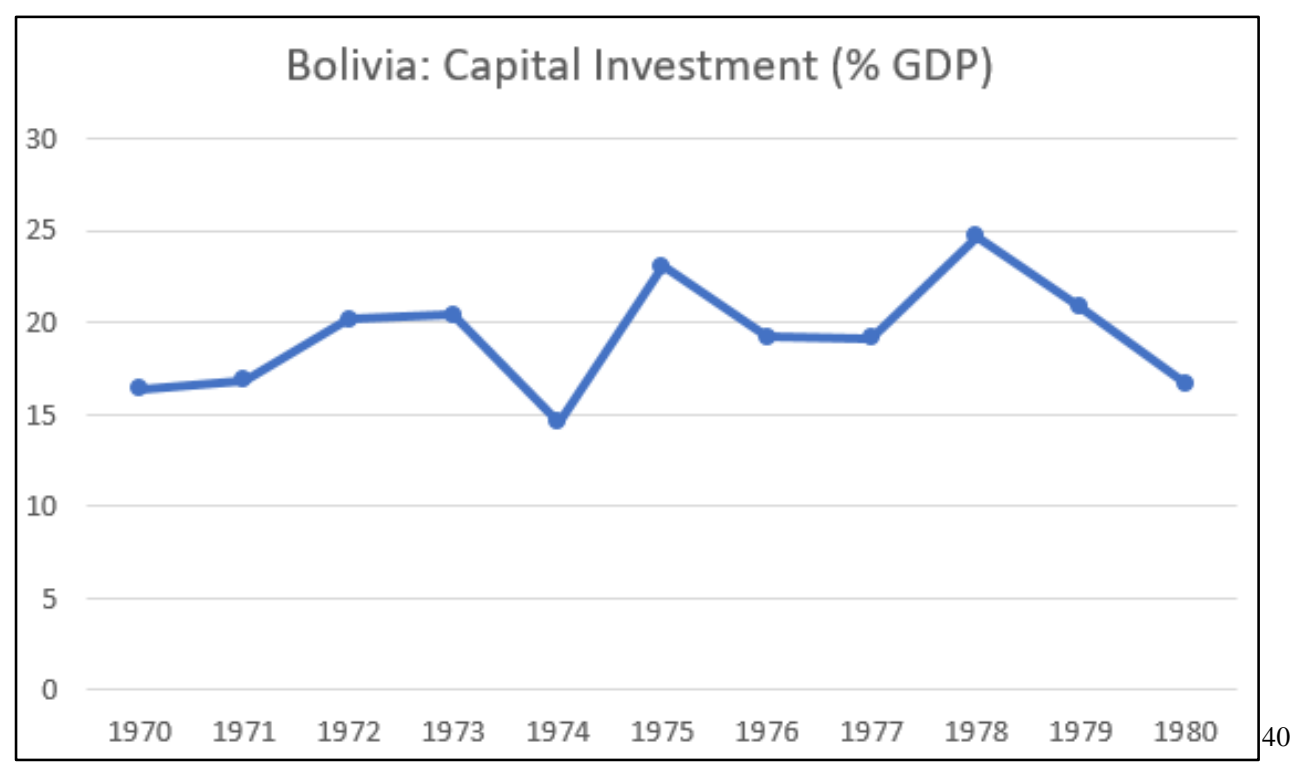

Graph 15: Bolivia Capital Investment (\% GDP)

This plan was an initial success for Banzer, but short-lived as the boom was a direct result of the worldwide increase in commodity prices, particularly in hydrocarbon and mineral export revenues. Again, such an export-led model relied on the whims of international market forces, which were entirely out of Bolivia's control (see Graph 16, below).

Despite the increase in commodity prices, and associated revenue for the government, the clear winners under Banzer were the civilian and military leaders who controlled the dominant organizations of the economy. The big losers during this same period were mostly organized labor (mining, manufacturing, and construction), and agriculture (Dunkerley 2017, 305).

40 The Global Economy. http://www.theglobaleconomy.com/. Accessed 14 January 2018. 


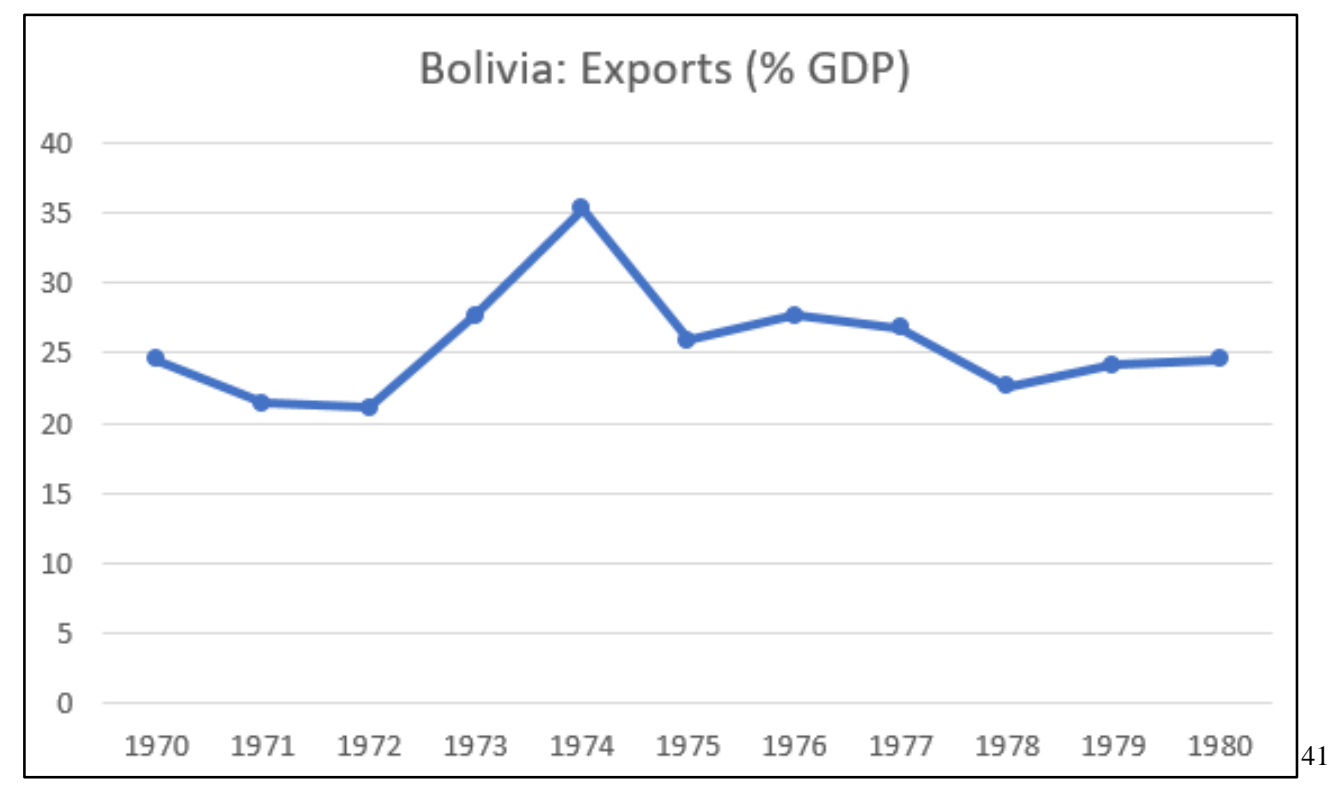

Graph 16: Bolivia Exports (\% GDP)

In Banzer's mind, democratic rule led to chaos. Only by depoliticizing and reeducating the population, could a stronger government emerge. Banzer believed popular political participation threatened economic growth in a capitalist economy (Dunkerley 2017, 296). Moreover, only through calculated political participation could the goal of rapid modernization take place. Such logic compelled Banzer to argue that military rule was not a short-term option, but a long-term solution to the crisis in Bolivia.

Banzer, supported by the center and right of Bolivian politics, to include Santa Cruz elites, represented a major turning point in national development. It was at this time that some of the actions of previous administrations fed into trends that came to some fruition during Banzer's rule. For example, Bolivia experienced improved economic performance, continued as a major exporter of agricultural products, and there was

${ }^{41}$ The Global Economy. http://www.theglobaleconomy.com/. Accessed 14 January 2018. 
development in the manufacturing sector amid a construction boom (see Graphs 17 and 18, below).

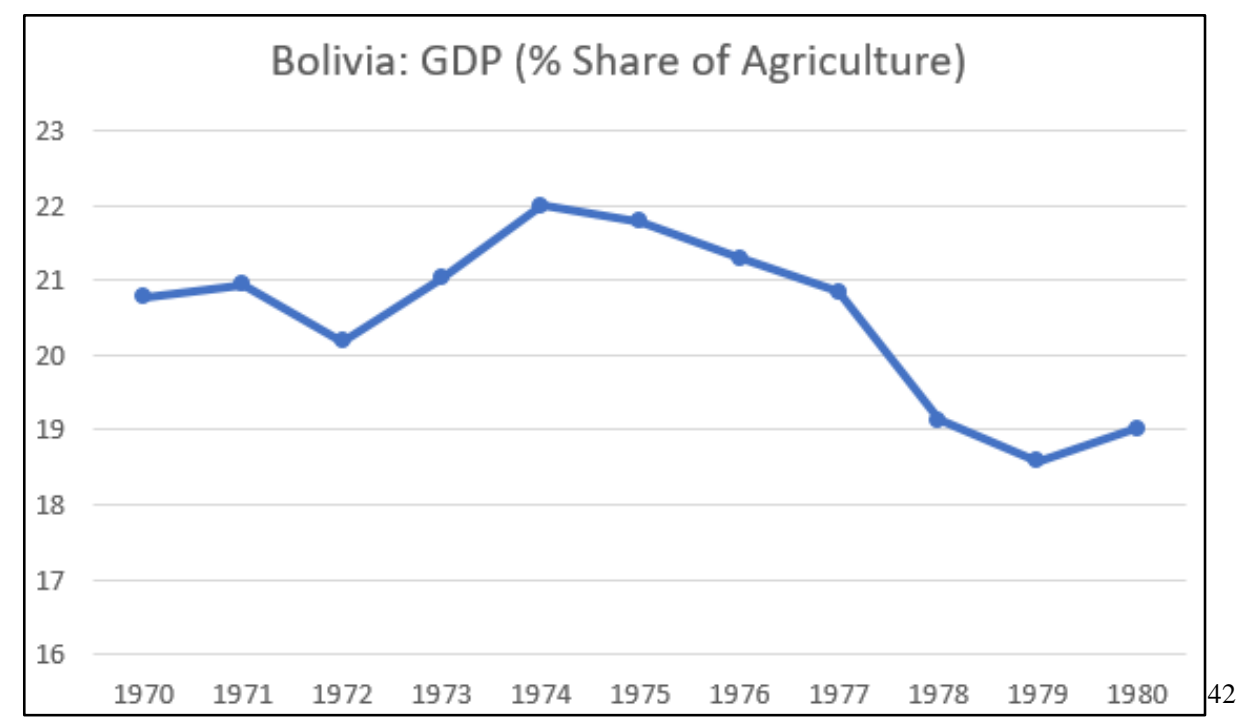

Graph 17: Bolivia GDP (\% Share Agriculture)

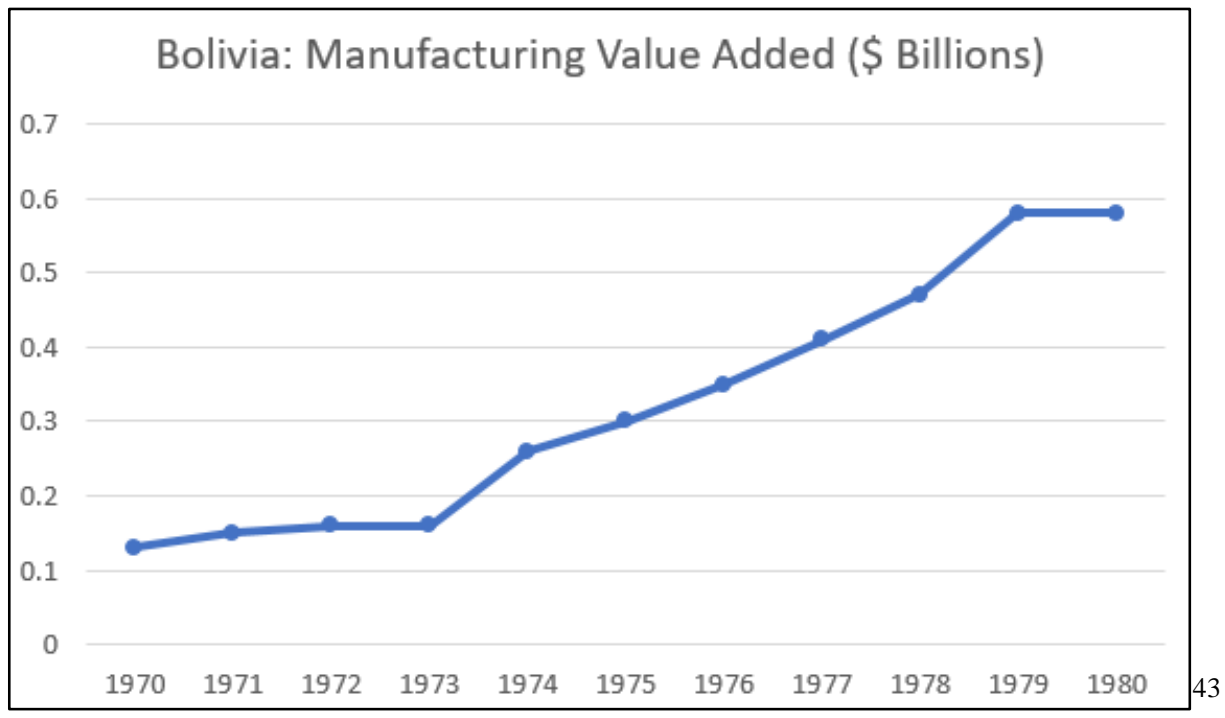

Graph 18: Bolivia Manufacturing Value Added (\$ Billions)

${ }^{42}$ The Global Economy. http://www.theglobaleconomy.com/. Accessed 14 January 2018.

${ }^{43}$ The Global Economy. http://www.theglobaleconomy.com/. Accessed 14 January 2018. 
Years of education funding also reached maturity as Bolivia produced many technical experts that would go on to fill private sector positions across the country. Many of these changes in Bolivia formed part of a larger trend in South America's political development.

Banzer's model did not differ much from that of Barrientos. To implement the model more efficiently, Banzer carried out a self-coup to justify the creation of a nonparty military government. Banzer's actions were not out of the ordinary for the region at that time in that non-democratic authoritarian regimes were then becoming the norm (Dunkerley 2017, 296). Ultimately, Banzer's regime was not to last. Social forces released by the economic boom at the time were not to be controlled. Moreover, the military remained fractured under Banzer's leadership.

The Bolivian economy ultimately declined as the Banzer government never effectively confronted the root structural problems within the economy. The subsequent worldwide drop in commodity prices in the early-1980s resulted in Bolivia entering one of the longest economic depressions in its history, which would last into the 1990s (Klein 1992, 268). Faced with this crisis, the military dictatorship was something Bolivia could ill afford. Bolivia's dictatorship was anachronistic. Its violent, oppressive, and exploitative nature was clearly unable to harness, let alone control, such a highly mobilized society. The forced resignation of Bolivia's last military junta in 1982 ended authoritarian regimes in the country.

Banzer concluded that regional atmospherics were changing, and his call for elections reflected the trend away from authoritarianism to formal democracy. The central issue in Bolivian politics remained economics and its ties to world commodity 
prices, which often undermined the state's ability to finance itself (Wanderley 2007, 203). Banzer began to lose control after his November 1978 announcement to move toward formal democracy. The left was split into two fronts, and the right was more nationalist. All concluded there was an economic crisis at the door. The economic situation compelled all parties to accept the necessity of imposing an austerity program (Malloy and Gamarra 1988, 139). Hernan Siles Zuazo of the left won the election. After a rocky period of short-term presidents, General Luis Garcia Meza Tejada took charge of a military junta and led a ruthless and effective coup, which arguably was accomplished with outside, particularly Argentine, support (Malloy and Gamarra 1988, 144).

The Garcia Meza government was short-lived, had no coherent plan or goals for Bolivia, and its brutality terrified civil-society (Dunkerley 2017, 401). Additionally, the government had connections to neo-fascists as well as the cocaine trade. Garcia Meza was removed in August 1981 by the officer corps, but the system which surrounded Garcia Meza remained solidly in place.

After Garcia Meza was removed, General Celso Torrelio Villa kept the system in place for roughly a year with the goal to end Bolivia's international isolation. Under U.S. pressure, Torrelio moved to redemocratize the country over a period of three years. A leading force of this effort was the Confederation of Bolivian Private Entrepreneurs (CEPB). ${ }^{44}$ In September 1982, the military high command accepted a civilian-designed exit, removed Torrelio, and handed over power under the condition that Siles Zuazo,

\footnotetext{
${ }^{44}$ The CEPB goal to democratize, as was the goal of many, was not because of a pure commitment to democracy, but years of disillusionment with authoritarianism; essentially, Bolivia turned to democracy as a second-best choice (Malloy and Gamarra 1988, 119, 150).
} 
winner of the 1980 election, would enter the presidency. A reconstituted Congress elected Siles Zuazo, thus resurrecting the old political system (Klein 1992, 269). Siles Zuazo inherited an economic disaster, which would worsen amid a decline in the tin mining industry.

Siles Zuazo’s presidency was formed around a coalition that included some elements of the MNR, personalities from the MIR, and the Bolivian Communist Party. ${ }^{45}$ The military was finally neutralized in the political sense. The thrust of Siles Zuazo's policies was a series of economic packages to rescue Bolivia from its economic turmoil. No matter what package Siles proffered, it would ultimately not please the main power bases in Bolivia (neither the CEPB nor the COB would be satisfied). After several years of dissatisfaction from both the right and left, power was handed over through elections in 1985 (see Table One, below).

\begin{tabular}{|l|l|l|}
\hline \multicolumn{2}{|c|}{ Bolivian Parties Competing during 1985 Elections } \\
\hline \multicolumn{1}{|c|}{ Left } & \multicolumn{1}{|c|}{ Center } & \multicolumn{1}{c|}{ Right } \\
\hline $\begin{array}{l}\text { Siles Zuazo (progressive } \\
\text { wing of MNR) }\end{array}$ & $\begin{array}{l}\text { Paz Estenssoro (historic } \\
\text { MNR) }\end{array}$ & $\begin{array}{l}\text { Banzer's ADN (included } \\
\text { the old Falange, a } \\
\text { reconstituted PIR, and } \\
\text { some new economic } \\
\text { elites) }\end{array}$ \\
\hline $\begin{array}{l}\text { Traditional labor allies, } \\
\text { emerging peasant leaders, } \\
\text { and radical intellectuals of } \\
\text { MIR }\end{array}$ & $\begin{array}{l}\text { Incorporated the old center } \\
\text { and right wing of MNR }\end{array}$ & $\begin{array}{l}\text { Some parties of the 1970s } \\
\text { and 1980s, but more } \\
\text { developed }\end{array}$ \\
\hline
\end{tabular}

Table One: Bolivian Political Parties (1985 Elections)

\footnotetext{
45 The MIR was a 1970s leftist revolutionary movement, inspired by Che Guevara, and emerged among young middle-class Bolivians.

${ }^{46}$ For a thorough discussion of Bolivian political parties during this period, see Malloy and Gamarra (1988).
} 
The outcome of the 1985 election placed Victor Paz Estenssoro in the presidency once again. Upon entering office, he would tackle the economic crisis by enacting strong austerity measures, first decentralizing the two main state enterprises COMIBOL and YPFB. Paz Estenssoro's New Economic Policy (NEP) reflected four important shifts. First, he implemented severe austerity. Second, he revised the role of the state in society. Third, the primacy of the state in development retreated. Fourth, Paz Estenssoro opened the economy to the international system and began negotiations with international creditors (see Graphs 19 and 20, below).

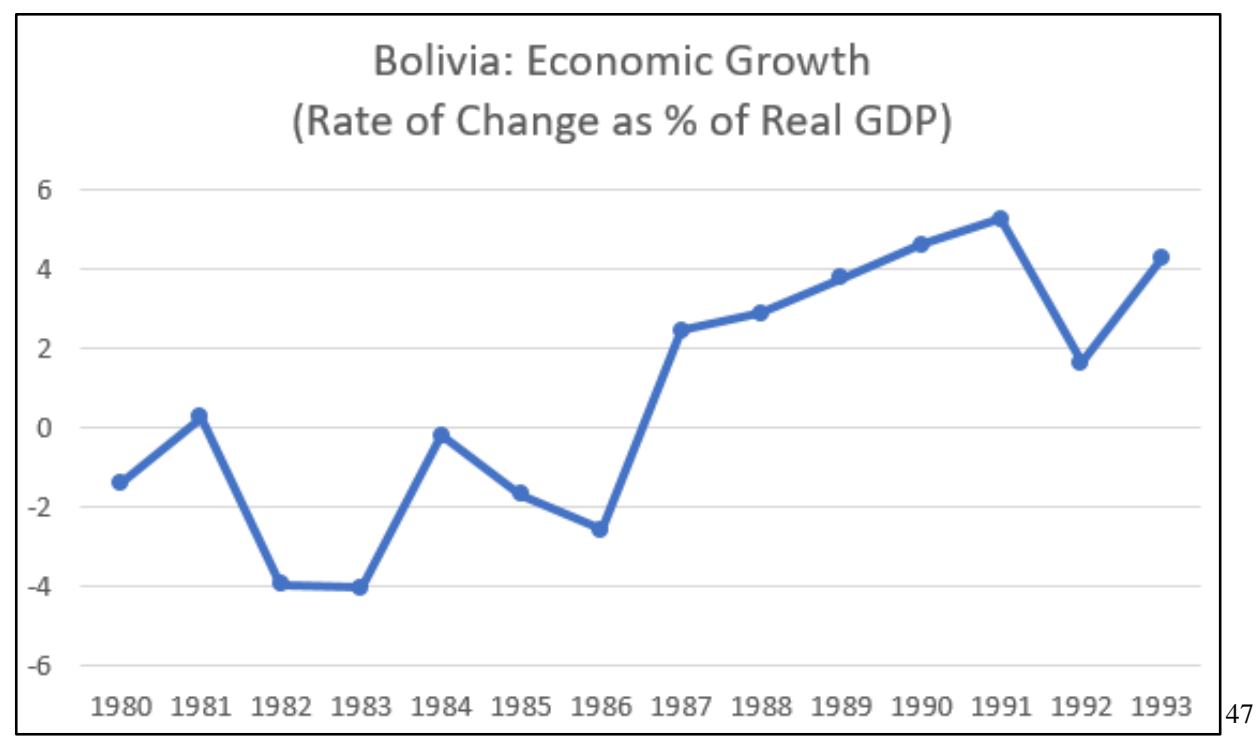

Graph 19: Bolivia Economic Growth (Rate Change as \% Real GDP)

${ }^{47}$ The Global Economy. http://www.theglobaleconomy.com/. Accessed 14 January 2018. 


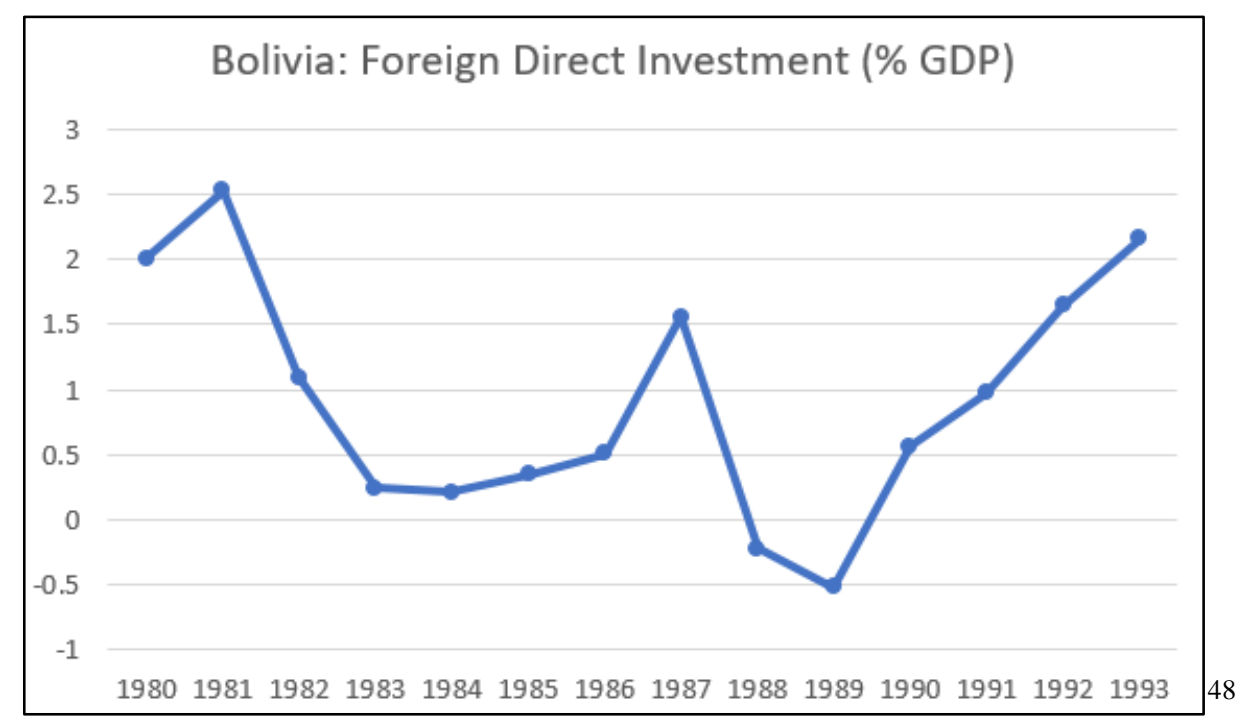

Graph 20: Bolivia Foreign Direct Investment (\% GDP)

The Neoliberal Era:

As evidenced by the series of military leaders during the 1970s and 1980s, the question germane to this dissertation is why Bolivia pursued neoliberal policies during its military dictatorships. In the 1980s, Bolivia surfaced from twenty years of military repression and was soon thereafter thrust into an environment of simultaneous neoliberal economic reform amid transition to a nascent formal democracy.

The two historic boogeymen of Latin American economies have been inflation and balance of payments, and the 1980s' drop in the price of tin and natural gas resulted in an excess of currency (see Graph 21, below). Amid an excess of currency and a downturn in commodity prices, Bolivia degenerated into deep economic depression and hyperinflation. The Bolivian peso collapsed in 1982 (renamed the Boliviano in 1986),

${ }^{48}$ The Global Economy. http://www.theglobaleconomy.com/. Accessed 14 January 2018. 
and one of the country's most powerful unions called hundreds of strikes. This simultaneous economic onslaught delivered a severe political crisis to Bolivia. Paz Estenssoro placed into practice the idea that fiscal restraint would stabilize or revive the economy enough to attract foreign capital. Bolivia's emergence from roughly twenty years of military repression began its attempts at joint economic and political reform by accepting an economic model that would become widely known as the Washington Consensus (Sachs and Morales 1990, 188).

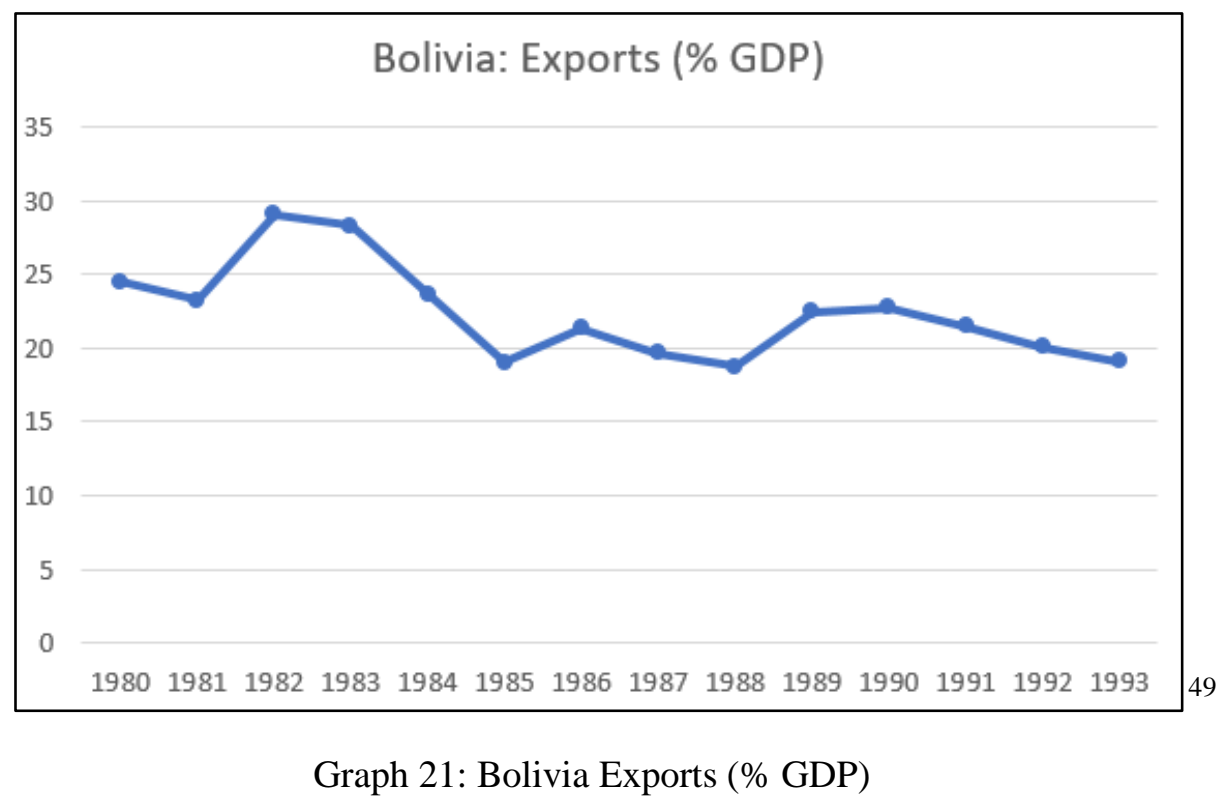

The NEP under Paz Estenssoro stopped hyperinflation in its tracks and restored economic growth and increased GDP per capita (see Graph 22, below). Paz Estenssoro was able to push through these reforms as power was increasingly concentrated into the presidency.

${ }^{49}$ The Global Economy. http://www.theglobaleconomy.com/. Accessed 14 January 2018. 


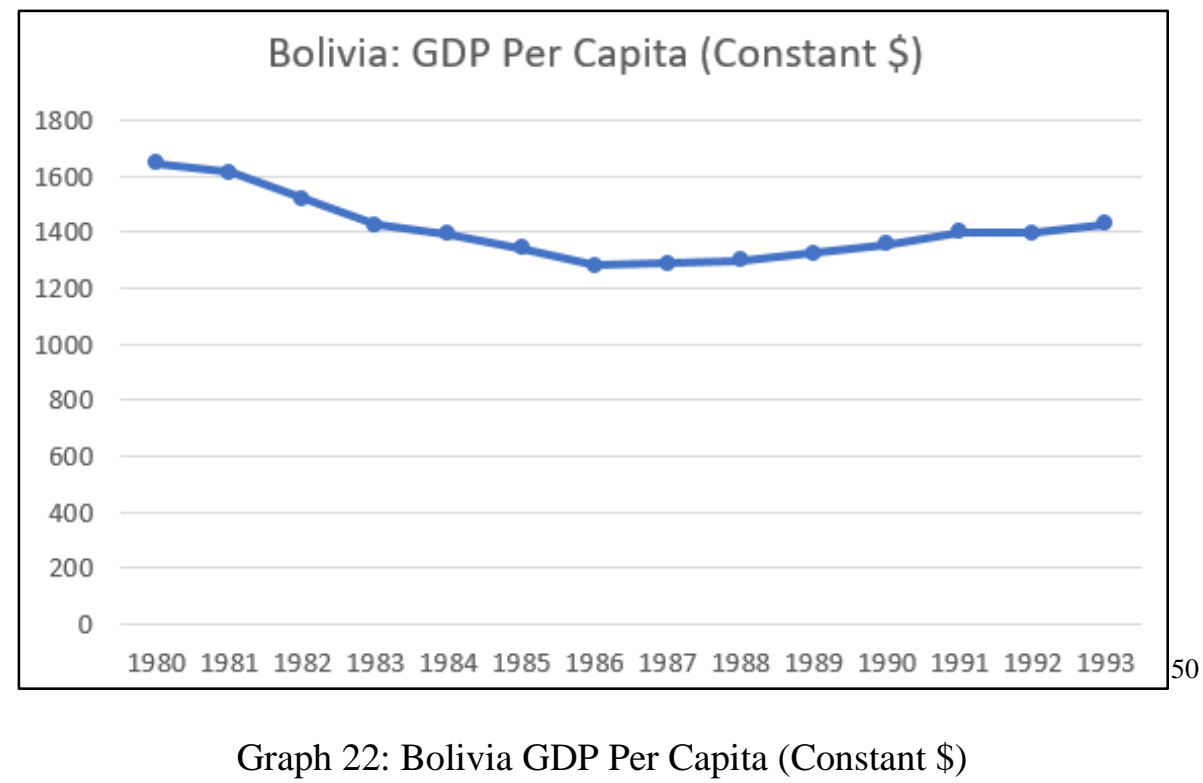

As Bolivia again faced a joint economic and political crisis, so again did Victor Paz Estenssoro enter politics, returning as president in 1985. Upon Paz Estenssoro's return to the presidency, he crippled the powerful COMIBOL and operated under the logic that fiscal restraint would ultimately create a safe place for businesses to invest capital, thus resulting in economic development. ${ }^{51}$

Paz Estenssoro's New Economic Plan (NEP) put forth in August 1985 embraced many of the proposals in Banzer's National Democratic Action Party's (ADN) economic plan. Co-opting Banzer's plan compelled him to accept Paz Estenssoro's economic vision for Bolivia. Essentially, the NEP (Decree \#21060) was an orthodox shock treatment for Bolivia, which included measures such as currency devaluation, floating

\footnotetext{
${ }^{50}$ The Global Economy. http://www.theglobaleconomy.com/. Accessed 14 January 2018.

${ }^{51}$ It is important here to note the rise (and return) of politicians throughout twentieth century Bolivia centers around the recurring theme whereby candidates enter office on a platform promising rapid development and change across social, political, and economic realms. The latest manifestation of this phenomenon was the election of Evo Morales, who at the time of writing remains president of Bolivia. For a discussion of Bolivia's "refoundation" and "constrained originality," see Whitehead 2008.
} 
exchange rates, new taxes, improved collection of taxes, and a cutback in government spending (Malloy and Gamarra 1988, 196). Out of control inflation plummeted after the implementation of the NEP (Sachs and Morales 1990, 241). Economic growth soon returned.

During the first half of the 1980s, Bolivia faced an astonishing crisis. Major external shocks such as the rise in interest rates and a cutoff from foreign lending came at the same time as the world price decline in Bolivia's commodity exports. The resulting hyperinflation was one of the wildest in world history. Even more remarkable was Bolivia's recovery after the implementation of the stabilization plan under Paz Estenssoro (Sachs and Morales 1990, 159).

The stabilization plan under Paz Estenssoro eliminated hyperinflation despite additional subsequent shocks coming about after its implementation (see Graphs 23, 24, and 25 below). At the time, terms of trade suffocated real income and exacerbated the already bitter political conflicts in the country at the time. Moreover, there was a reduction in government revenue that threatened the stabilization plan (Sachs and Morales 1990, 160). 


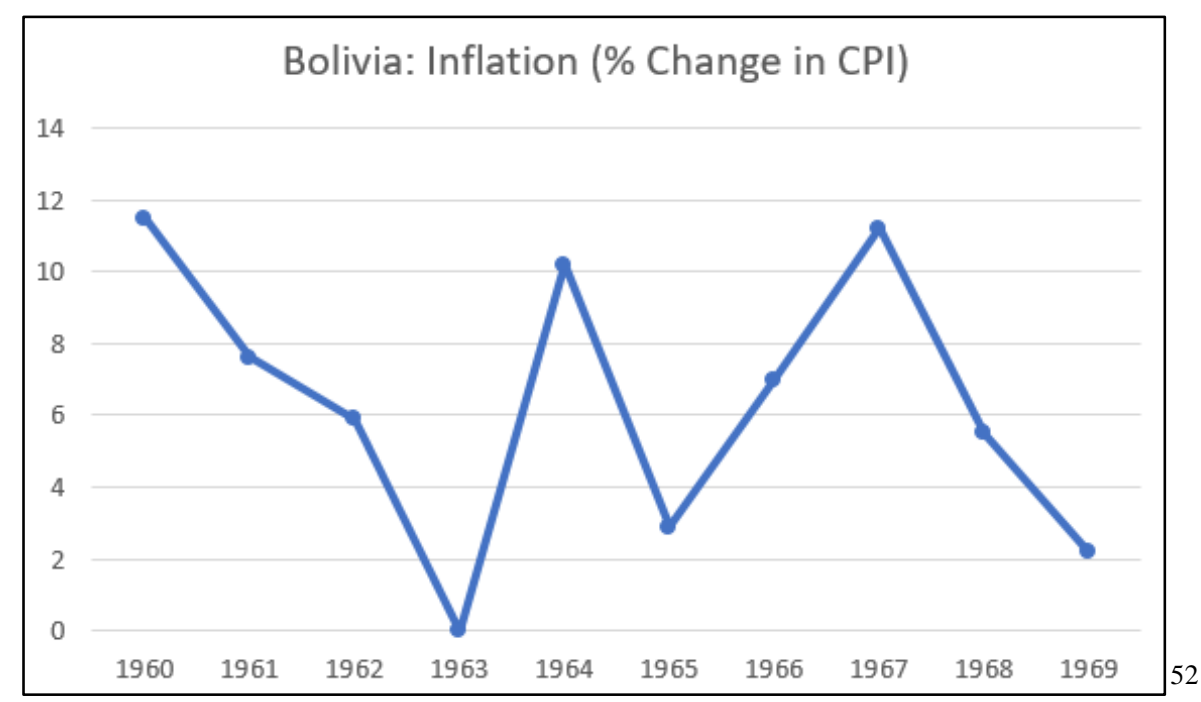

Graph 23: Bolivia Inflation (\% Change in CPI)

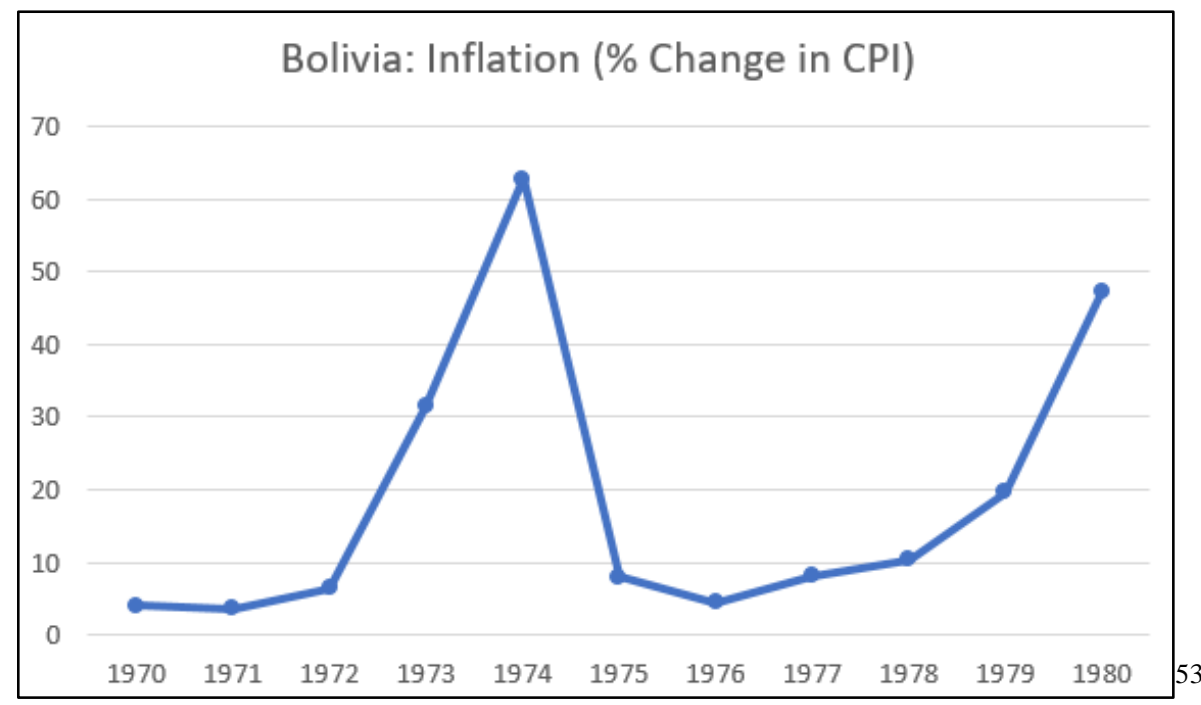

Graph 24: Bolivia Inflation (\% Change in CPI)

${ }^{52}$ The Global Economy. http://www.theglobaleconomy.com/. Accessed 14 January 2018.

${ }^{53}$ The Global Economy. http://www.theglobaleconomy.com/. Accessed 14 January 2018. 


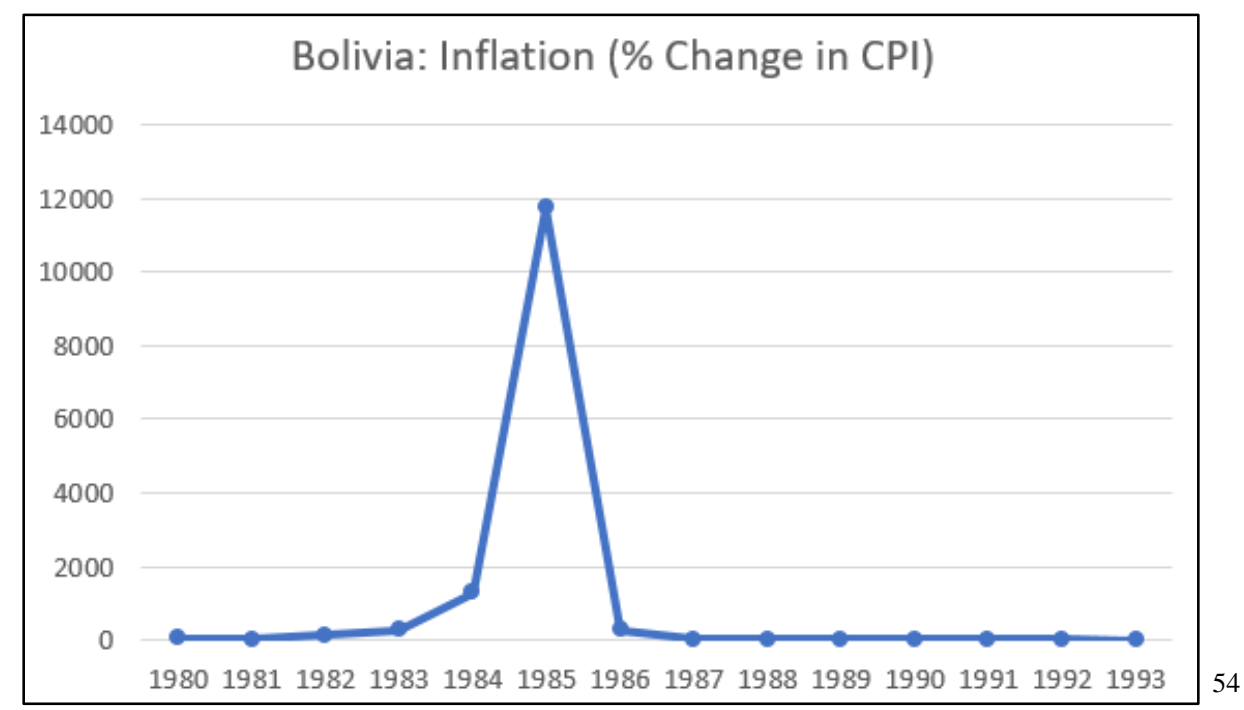

Graph 25: Bolivia Inflation (\% Change in CPI)

Paz Estenssoro, the former populist and economic nationalist, reinvented himself and fully embraced economic liberalism. Economic nationalism and state capitalism were the very ideas he pushed when in office decades prior. The calamitous economic reality in Bolivia permitted Paz Estenssoro to carry out such drastic measures. The gutting of COMIBOL from 30,000 to 7,000 employees and the reduction of YPFB by 4,000 workers were inconceivable only a few years prior (Klein 1992, 276). As a clear result, organized labor was politically weakened (see Graph 26, below).

54 The Global Economy. http://www.theglobaleconomy.com/. Accessed 14 January 2018. 


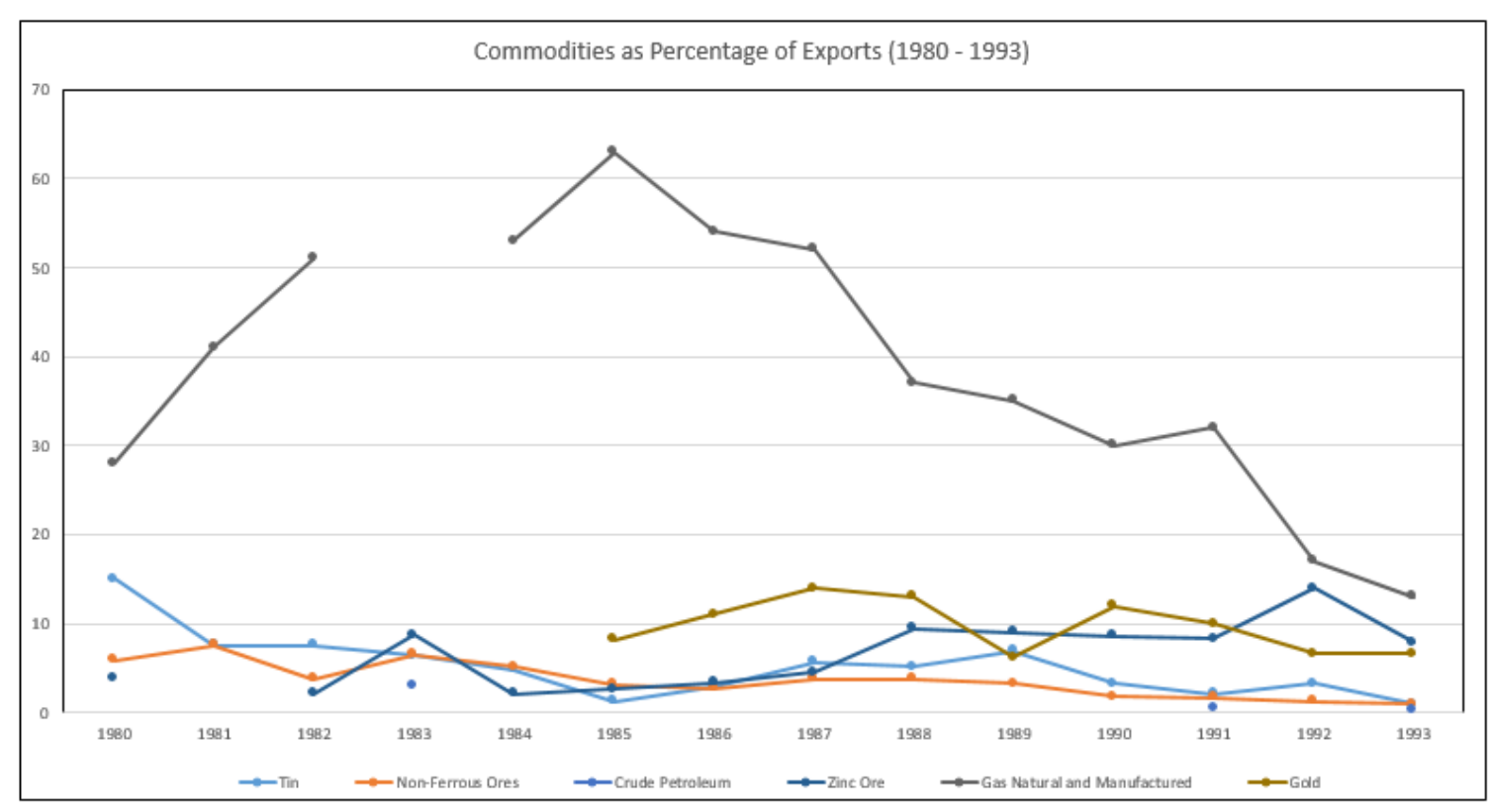

Graph 26: Bolivia Commodities as Percentage of Exports

After Paz Estenssoro implemented the NEP, no subsequent politicians challenged the plan's logic. Jaíme Paz Zamora of the center-left MIR (1989-1993) maintained the open market policies of Paz Estenssoro despite the opposition from his own party as well as that of organized labor. Gonzalo Sánchez de Lozada of the MNR (1993-1997) continued the policies of Paz Zamora, and is seen by many as the architect of free market reforms in Bolivia.

As Sanchez de Lozada prepared for the 1993 elections, he faced popular pressure for faster results after the implementation of earlier the stabilization program juxtaposed against popular anxiety over the effectiveness of those solutions. Because of his actions as Minister of Planning during the mid-1980s stabilization program, Sanchez de Lozada

${ }^{55}$ MIT. The Observatory of Economic Complexity. http://atlas.media.mit.edu/en/. Accessed 14 January 2018. 
ran for office in 1993 amid a stable economy, but with little growth (see Graph 27). Capitalization was floated as a possible solution (Ewing and Goldmark 1994, 1). ${ }^{56}$

At the time, the state remained the central player in Bolivia's important sectors (mining, hydrocarbons, and public utilities). Bolivians were suspicious of privatization and feared a loss of jobs as well as the nation's patrimony. The privatization taking place under Sanchez de Lozada was unique in that it combined an appeal to popular participation with that of retaining the buyers" payment in the business. The "Plan de Todos" was a uniquely Bolivian model of capitalization, and was essentially a simple privatization model for six large state enterprises. Under this plan, the buyers would pay into the company itself instead of the government, thereby doubling the firms' net worth. The resultant cash injection would be used to invest in the sectors to stimulate their expansion, improve efficiency, and create jobs (Ewing and Goldmark 1994, 2). Thinking at the time was that the funds would better serve ordinary Bolivians if they remained under the control of private owners rather than the government. The fear was that government control of the money would open it to corruption and inefficiency. Private retention of the funds would encourage additional investment.

\footnotetext{
${ }^{56}$ Capitalization is privatization with the difference being that sale proceeds remain with the company to finance future investment. Such an approach is relevant when assets for sale are of interest to a strategic investor, a government can afford to relinquish direct proceeds of the sale, or the sector requires major investment. In the case of countries where nationalism is a powerful force, capitalization is often preferable to avoid popular political backlash. For a discussion of capitalization and Bolivia's YPFB, see Dunkerley 2007.
} 


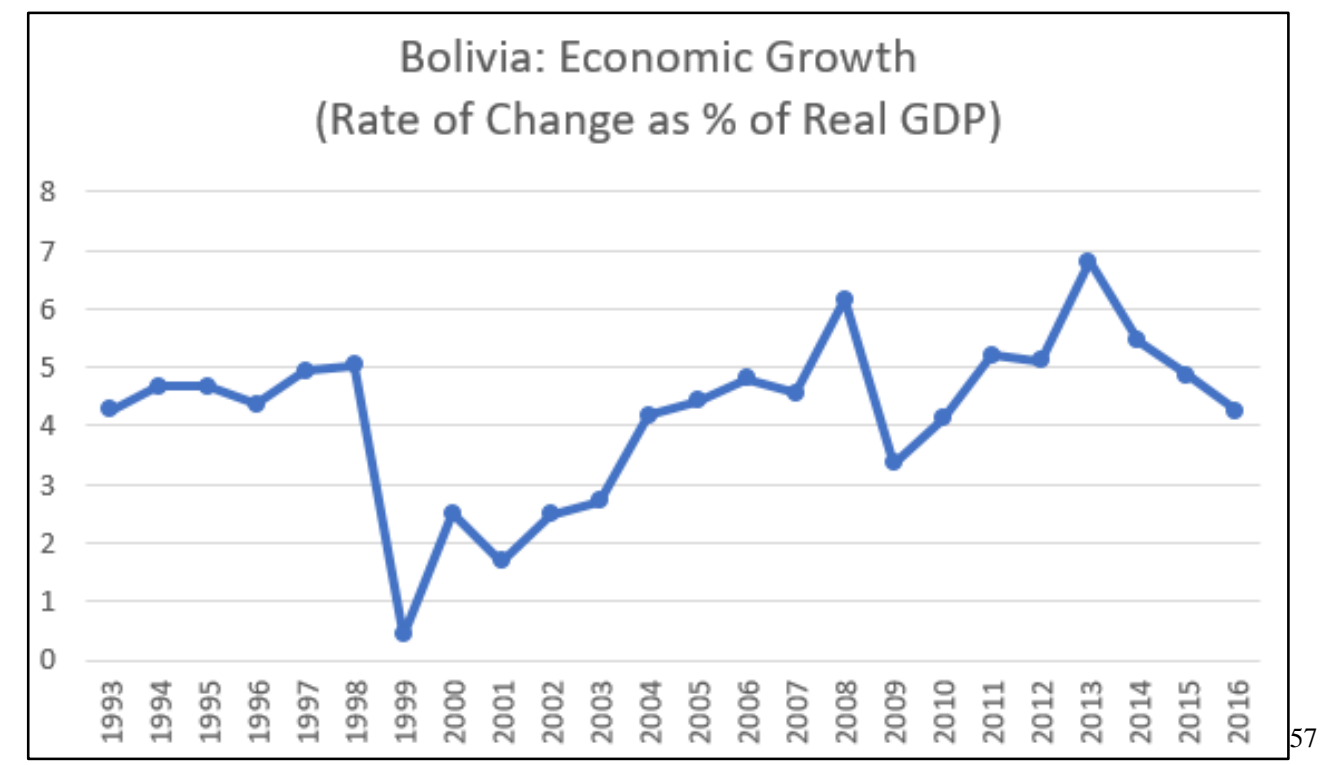

Graph 27: Bolivia Economic Growth (Rate Change as \% Real GDP)

Germane to this turbulent period is YPFB and its relationship with Petrobras. In 1999 the YPFB ended over sixty years of control as the state oil firm. After Banzer's health-related resignation, Jorge Quiroga Ramirez (2001-2002) briefly took the reins of government, and was followed by Sanchez de Lozada (2002-2003) who ultimately succumbed to a series of political protests in 2003 (he was caught in a downward commodity cycle), and resigned in October of that year. Of note, what would later be referred to as the Gas War in Bolivia took place under the Sanchez de Lozada administration as violent protests resulted from the government's plan to export Bolivian natural gas to the U.S. through Chile. ${ }^{58}$ The plan was rescinded; however, the damage

\footnotetext{
${ }^{57}$ The Global Economy. http://www.theglobaleconomy.com/. Accessed 14 January 2018.

${ }^{58}$ The invocation of Bolivia's littoral access argument is an example of a populist approach to governance. Since the end of the War of the Pacific against Chile (1879-1884), when Bolivia lost its access to the Pacific Ocean, Bolivian leaders have used the argument that sea access is vital for the country. Of note, this argument is made when Bolivia is in an economic or political crisis and may be considered as an approach to galvanize the people towards one policy or another (i.e. 1930s Military Socialists; 1950s revolutionaries; military dictatorships of the 1970s; Sanchez de Lozada, then Gisbert). Morales has not shied away from similar rhetoric.
} 
was done and Sanchez de Lozada left office. The presidency of Carlos Mesa Gisbert (2003-2005) ends this period of executive branch instability in Bolivia.

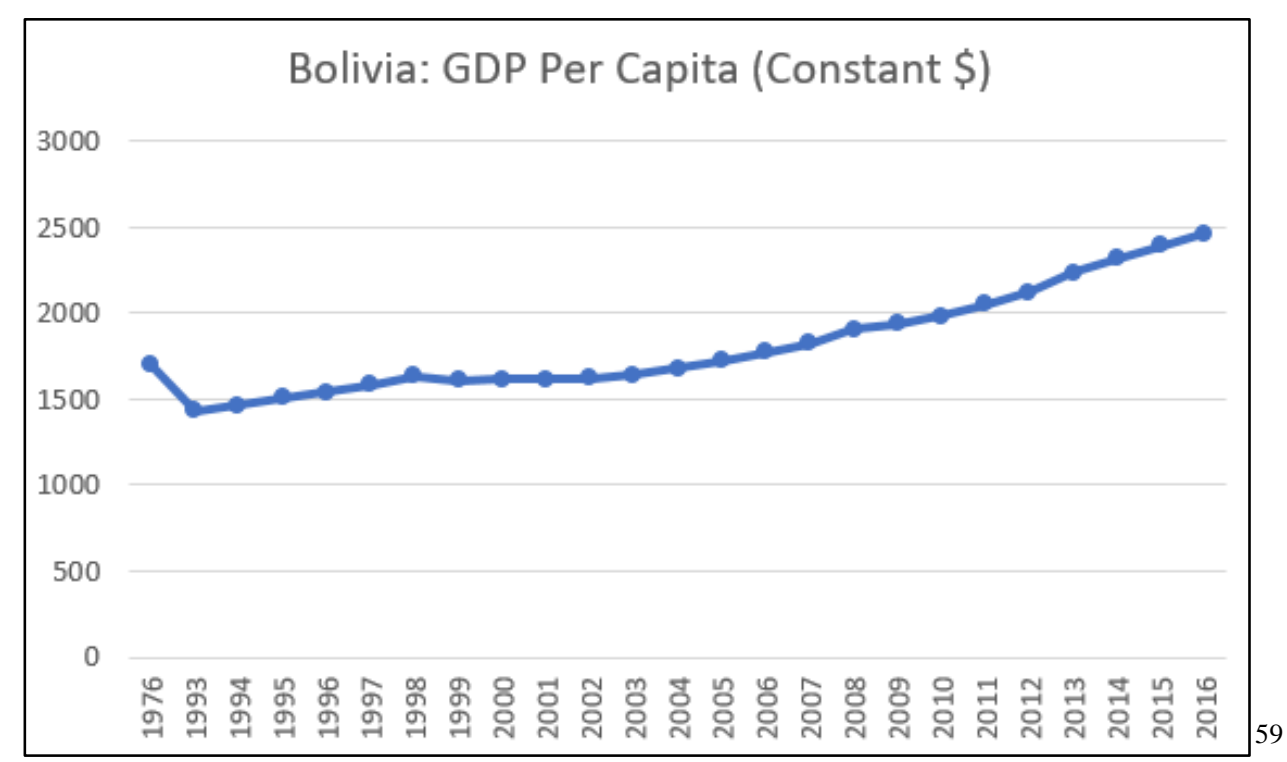

Graph 28: Bolivia GDP Per Capita (Constant \$)

The series of presidents from 1989 to 2005 maintained the open market approach initially put in place under Paz Estenssoro in 1985, and continued to implement policies that ensured the Bolivian economy would continually grow and integrate itself into the world economy (see Graph 28, above). Evo Morales of the Movement Towards Socialism (MAS) party took advantage of the downward commodity cycle, erroneously blamed neoliberal policies for Bolivia's predicament, emerged as a serious political force, assumed the presidency in 2005 , and remains in power today.

\footnotetext{
${ }^{59}$ The Global Economy. http://www.theglobaleconomy.com/. Accessed 14 January 2018.
} 
Evo Morales' Bolivia (Populism and Economic Nationalism, Again?):

To understand Bolivia and the election of the historical outsider, anti-elite, Morales, one must understand the events leading up to his presidency. Morales was influential in the fall of Gonzalo Sanchez de Lozada of the MNR in 2003 (October Gas War) and the independent candidate Mesa Gisbert in 2005. The rise of Morales must be seen in the context of a globalizing economy combined with two decades of neoliberal reform and simultaneous experimentation in deepening democracy.

In May 2006 President Morales ordered the military to occupy energy fields around the country and to nationalize the country's oil and gas reserves. The U.S. historically lacked large hydrocarbon investments in the country; however, Brazil's Petrobras and Spain's Repsol, firms with larger amounts of investment in Bolivia, certainly felt the sting of Morales' move. In hindsight, Morales' nationalization of Bolivian natural gas was not as effective as Venezuela's nationalization of oil; gas is a regional, not international, market (Weintraub 2006, 2). Moreover, Bolivia's reserves pale in comparison to those of Venezuela. These two points are further developed in the case study.

Morales' first major action was to use the military to seize energy fields throughout Bolivia and subsequently placed these under state control. Foreign producers were required to funnel future sales of hydrocarbons, particularly natural gas, through the YPFB. Drawing on a history of foreign sacking of its wealth, Morales resurrected Bolivian nationalism as policy. Under the Heroes of the Chaco Declaration (Supreme 
Decree No. 28701), Morales upended the historically disadvantageous relationship between Bolivia and foreign firms (Miranda 2008, 193). ${ }^{60}$

The new economic relationship between Bolivia and international firms provided the former with greater natural resource wealth to spend and invest domestically (see Graph 29, below). It is important to note here that the capitalization reforms of the 1990s were crucial in Morales' success. During the 1990s, natural gas became the largest commodity export, and provided the most revenue relative to other exports (see Graph 30, below). Ironically, Morales' resource nationalism was made possible because of the NEP enacted under Paz Estenssoro, not despite it.

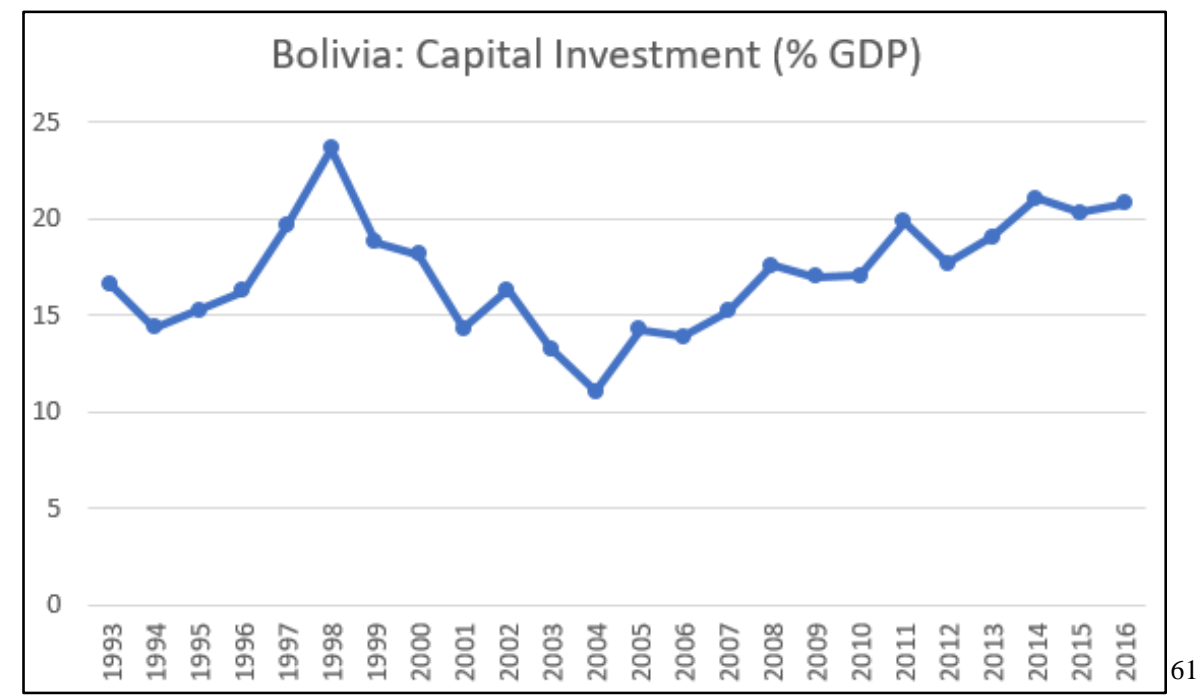

Graph 29: Bolivia Capital Investment (\% GDP)

\footnotetext{
${ }^{60}$ The Heroes of the Chaco Declaration was the document that nationalized hydrocarbons in Bolivia. In this declaration, President Morales stated that hydrocarbon activities were not carried out in line with constitutional requirements, and that the privatization and capitalization of YPFB was injurious to the state. Of the nine, the most central Articles are \#2 (nationalization) and \#4 (distribution of natural gas revenues from the largest fields: $82 \%$ for the government; 18\% for the companies) (Morales 2006, 1021).

${ }^{61}$ The Global Economy. http://www.theglobaleconomy.com/. Accessed 14 January 2018.
} 


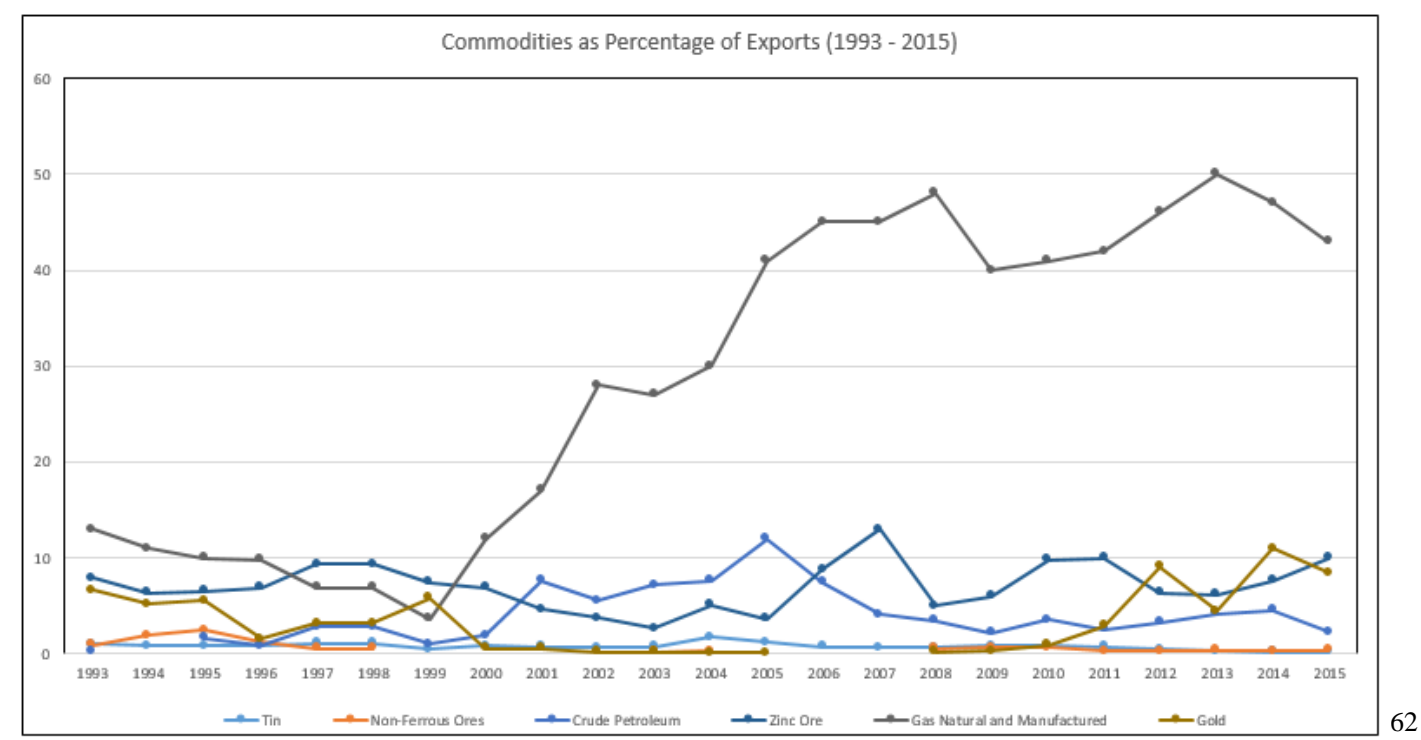

Graph 30: Bolivia Commodities as Percentage of Exports

In the minds of the historically marginalized populations, as well as in those of careful outside observers, it would appear the legacy of the plundering of Potosí was finally avenged. Nevertheless, foreign interests continued to invest in Bolivia. After a brief hiccup in 2005, FDI was on the rise again. Exports increased greatly after Morales took office, almost tripling in some years, since the Sanchez de Lozada era. However, both exports and FDI are in decline since 2013 (see Graphs 31 and 32, below).

${ }^{62}$ MIT. The Observatory of Economic Complexity. http://atlas.media.mit.edu/en/. Accessed 14 January 2018. 


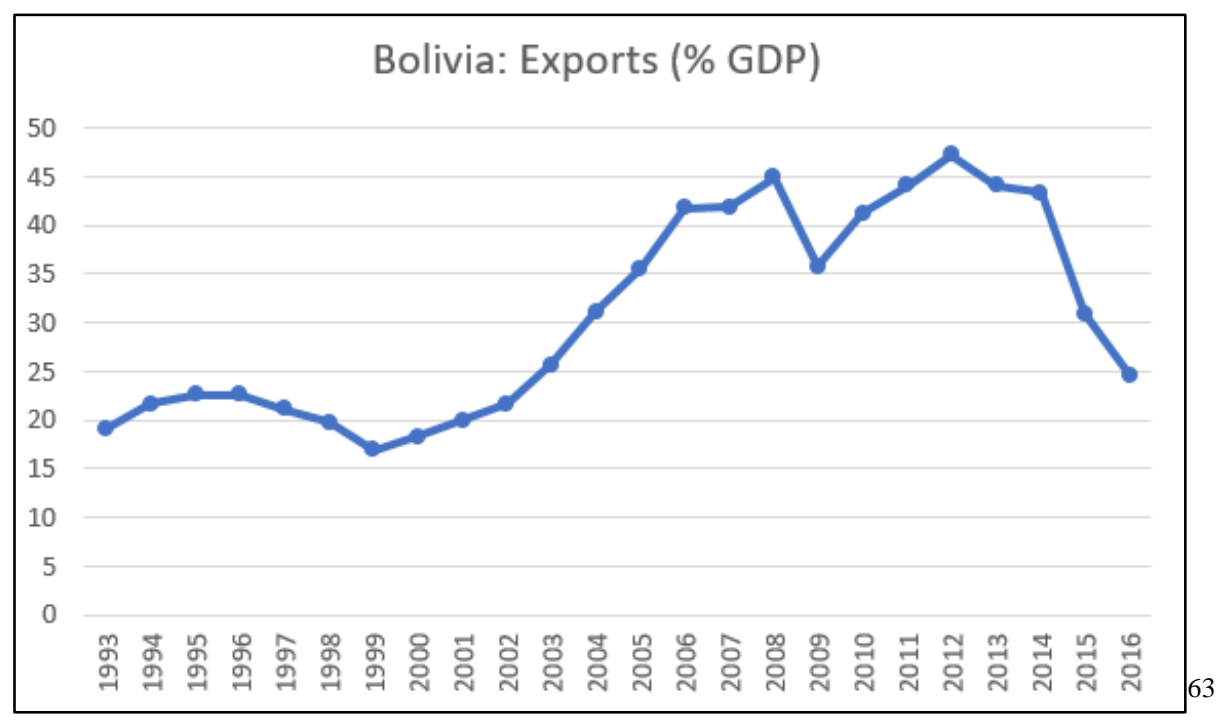

Graph 31: Bolivia Exports (\% GDP)

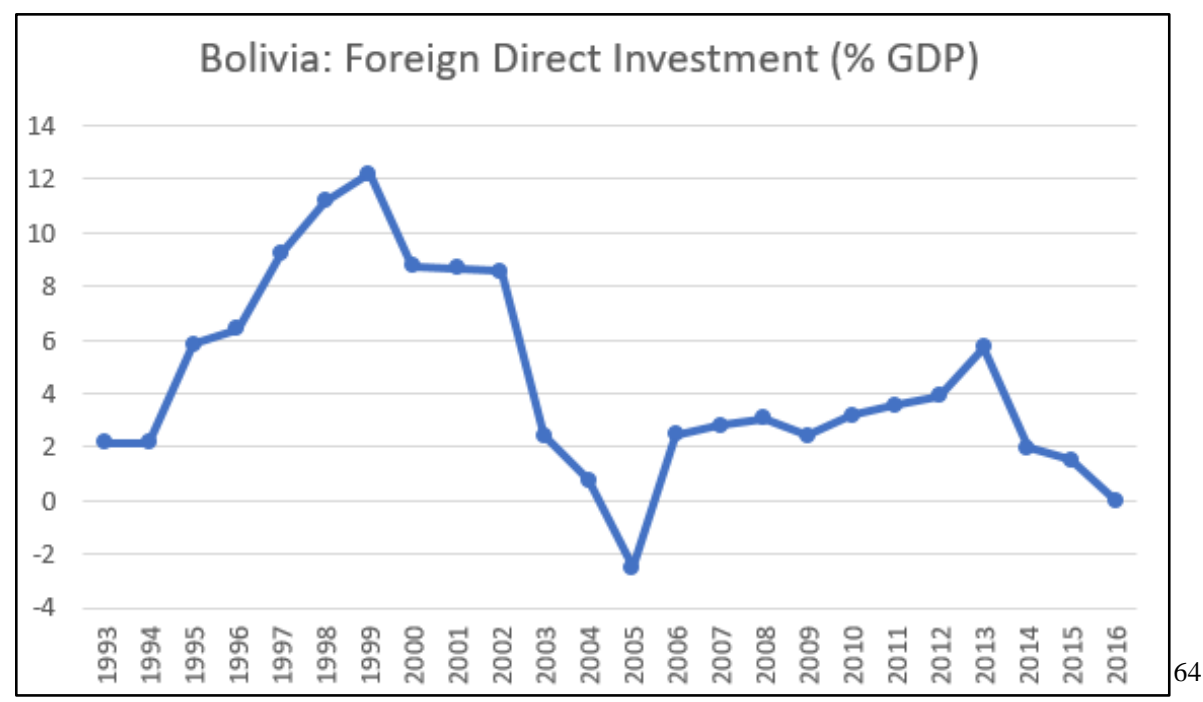

Graph 32: Bolivia Foreign Direct Investment (\% GDP)

Morales' political platform centered on promising to deliver social, political, economic, and cultural change. Contrary to the opinions of many policymakers and

\footnotetext{
${ }^{63}$ The Global Economy. http://www.theglobaleconomy.com/. Accessed 14 January 2018.

${ }^{64}$ The Global Economy. http://www.theglobaleconomy.com/. Accessed 14 January 2018.
} 
pundits, Morales' rise is not the first time in Bolivian history where a candidate entered office based on a platform of rapid change (Whitehead 2008, 269). Morales brought back to Bolivia a sense of national populism not seen for decades. The 2006 petroleum nationalization under Morales, clearly economically nationalist, was not unprecedented.

\section{Bolivia's Natural Gas Relationship with Brazil: A Synopsis}

This section centers on the natural gas relationship between Bolivia and Brazil, and provides a brief historical and contextual foundation on which later chapters depend. Principally, the natural gas trade relationship between Bolivia and Brazil did not develop overnight. Instead, the relationship was built on decades of groundwork dating to the 1950s within the Southern Cone of South America, with the first gas pipeline built in 1972 between Bolivia and Argentina (Mares 2004, 1). Over time, new discoveries of natural gas in Argentina decreased the need for Bolivian product. With $80 \%$ of Bolivia's total gas production being sold to Argentina at that time, Bolivia needed to secure a new export market.

In 1991, the governments of Bolivia and Brazil revisited a gas export project that had been a pipe dream for decades. Ultimately, Bolivian natural gas trade with Brazil triumphed over that of Argentina, led mostly by the GASBOL project (a natural gas pipeline from Bolivia to Brazil) which dovetailed with World Bank interest in the economic development of Bolivia (Mares 2004, 16). An initial twenty-year agreement between Bolivia's YPFB and Brazil's Petrobras was signed in 1993. 
Natural gas is Bolivia's main export and is $\sim 50 \%$ of the country's GNP. Bolivia and Brazil epitomize an ideal market relationship for natural gas in the region. However, Bolivia runs the risk of losing out on this deal if Brazil develops its own natural gas or finds another supplier. As the largest regional economy, Brazil will remain a key player in any Latin American energy integration scenario.

Pertinent to Bolivia and central to natural resource exploitation are the associated rents a government receives through the sale of commodities. It is evident that consecutive Bolivian administrations have harnessed natural gas rents. However, the government has been limited in its ability to use these rents to adjust economic course. Bolivia remains an export-dependent country. The twentieth century has simply seen a shift from tin and other mined resources to hydrocarbons (Wanderley 2008, 194).

\section{Works Cited}

Blasier, Cole. "The United States and the Revolution" in Beyond the Revolution: Bolivia Since 1952. Ed. James Malloy and Richard Thorn. University of Pittsburgh Press. 1971. Burke, Melvin and James Malloy. "From National Populism to National Corporatism: The Case of Bolivia (1952-1970).” Comparative International Development, Spring 1974, pp. 49-73.

De La Torre, Carlos and Cynthia J. Arnson, "Introduction." Latin American Populism in the $21^{\text {st }}$ Century, edited by Carlos de la Torre and Cynthia J. Arnson, Woodrow Wilson Center Press, 2013.

Dunkerley, James. "Evo Morales, the 'Two Bolivias' and the Third Bolivian Revolution.” Journal of Latin American Studies, vol. 39, no. 1, Feb. 2007, pp. 133-166

Dunkerley, James. "Rebelion en las Veinas: La Lucha Politica en Bolivia 1952-1982." Biblioteca del Bicentenario de Bolivia. 2017.

Ewing, Andrew and Susan Goldmark. "Privatization by Capitalization: The Case of Bolivia: A Popular Participation Recipe for Cast-Starved SOEs." FPD Note No. 31. World Bank. November 1994. 
Gamarra, Eduardo. "Bolivia: Beggar on a Throne of Gold." Culture and National Security in the Americas. Lexington Books. 2017.

Klein, Herbert S. "David Toro and the Establishment of 'Military Socialism' in Bolivia." The Hispanic American Historical Review, vol. 45, no. 1, Feb 1965, pp. 25-52.

Klein, Herbert S. "Social Constitutionalism" in Latin America: The Bolivian Experience of 1938." The Americas, vol. 22, no. 3, Jan. 1966, pp. 258-276.

Klein, Herbert S. "German Busch and the Era of 'Military Socialism' in Bolivia." The Hispanic American Historical Review, vol. 42, no. 2, May 1967, pp. 166-184.

Klein, Herbert S. "Bolivia: The Evolution of a Multi-Ethnic Society." Oxford University Press. Oxford. 1992.

Malloy, James. "Bolivia: The Uncompleted Revolution." University of Pittsburgh Press. Pittsburgh. 1970.

Malloy, James M. and Eduardo Gamarra. "Revolution and Reaction: Bolivia, 19641985.” Transaction Books. New Brunswick. 1988.

Miranda, Carlos. "Gas and Its Importance to the Bolivian Economy." Unresolved Tensions: Bolivia Past and Present. University of Pittsburgh Press, 2008.

Mitchell, Christopher. "The Legacy of Populism in Bolivia: From the MNR to Military Rule.” Praeger Publishers. New York. 1977.

Morales, Evo. "Bolivia: Supreme Decree No. 28701." International Legal Materials, vol. 45, no. 4, Jul. 2006, pp. 1020-1022.

O'Donnell, Guillermo. "Reflections on the Patterns of Change in the BureaucraticAuthoritarian State." Latin American Research Review, vol. 13, no.1, 1978, pp. 3-38.

Paredes, Rene Quenallata. "Bolivia Pressing ahead with Regional Energy Integration Plans.” Xinhua. 1 Jan. 2017.

Petronoticias. "Bolivia Procura Novos Compradores de Gas Natural." 9 Mar. 2017.

Ramos, Daniel. "Repsol Makes Major Natural Gas Discovery in Bolivia.” Reuters, http://www.reuters.com/article/bolivia-gas-repsol-idUSL2N15Z01G. 19 February 2016.

Sachs, Jeffrey D. and Juan Antonio Morales. "Bolivia's Economic Crisis" Developing Country Debt and Economic Performance, vol. 2. Ed. Jeffrey Sachs. National Bureau of Economic Research. University of Chicago Press. Chicago. 1990.

Siekmeier, James. "The Bolivian Revolution and the U.S. from 1952 to the Present." Pennsylvania State University Press. University Park, Pennsylvania. 2011.

Viga Gaier, Rodrigo. "Brazilian Study Urges Petrobras to Cut Bolivian Natural Gas Purchases." Reuters, 27 Jun. 2017. 
Wanderley, Fernanda. "Beyond Gas: Between the Narrow-Based and the Broad-Based Economy." Unresolved Tensions: Bolivia Past and Present. University of Pittsburgh Press, 2008.

Whitehead, Laurence. "Conclusion: Bolivia's Latest 'Refoundation." Unresolved Tensions: Bolivia Past and Present. University of Pittsburgh Press, 2008.

\section{Data Sources:}

British Petroleum. British Petroleum Statistical Review of World Energy. http://www.bp.com/statisticalreview. June 2015.

The Global Economy. http://www.theglobaleconomy.com/. Provides updated economic statistics from official sources (i.e. World Bank, International Monetary Fund, and the United Nations).

MIT. The Observatory of Economic Complexity. http://atlas.media.mit.edu/en/. 


\section{CHAPTER THREE}

\section{Brazil: Chapter Abstract}

This chapter begins with a contextual explanation of Brazil's twentieth century economic experience to provide the necessary background to ask the central research question concerning how resource nationalism affects energy integration. Next, this chapter explains Brazil's history during the same period, emphasizing when necessary central issues of the overall dissertation: economic nationalism (to include nationalizations), populism, natural resources, neoliberal policies, the historical election of Luiz Inácio "Lula" da Silva, and beyond. Statistical indicators paint a picture of Brazil's economic evolution across time. The final section provides rudimentary commentary and background concerning integration of Bolivian natural gas into Brazil, setting the stage for development of the case study.

\section{Brazil: Current Scenario}

In academia, there is not as much robust energy research involving Latin America compared to other regions. Within Latin America, Brazil is under-investigated. Brazil as regional hegemon, its ability to project power, its proximity to markets in the Americas, and its links outside of the hemisphere, particularly Lusophone Africa, all offer integration prospects. Brazil's need for natural gas is presently satisfied through imports. This presents the opportunity to determine the effects of Bolivian resource nationalism on what appears to be an ideal economic match concerning energy integration and cooperation between the two countries. 
Brazil and Bolivia nationalized their energy firms resulting from each country's unique historical experience. Often, nationalized oil companies (NOC) are anathema to strict reliance on a liberal global market, which differs from the Anglo-American economic model. Moreover, parastatals often function at the behest of the president in power and additionally take on social roles not initially envisioned when created (Victor et al 2012, 8).

This chapter is arranged mostly by electoral events and respective policy changes in Brazil. The first period centers on O Estado Novo (The New State) in Brazil during the long Getúlio Vargas era (1937-1954), includes historical precursors, the brief interregnum, Vargas' reelection in 1951, and the creation of Petrobras in 1953. The second period concerns military rule and dictatorship (1964-1985), as well as some of the debates concerning the role of Petrobras and surrounding political conflicts. Next is the bumpy post-dictatorship transition to formal democracy and economic restructuring under Fernando Henrique Cardoso (1995-2002), which includes discussions on economic imbalances, attempted solutions, subsequent democratic elections, and financial restructuring under the Cardoso Plan. The fourth period presents a discussion of the historical election of Luiz Inácio “Lula” da Silva (2002-2010), his handpicked successor, Dilma Rousseff (2010-2016), and the economic policies in effect during this period. Last, this chapter discusses the importance of regional energy integration with Brazil relative to deepened economic ties. ${ }^{65}$

\footnotetext{
${ }^{65}$ Deepened economic ties among countries in Latin America may preclude the need to sell to China, Russia, or other extra-hemispheric actors. Endearing Bolivian natural gas to Brazilian markets will benefit Bolivia, Brazil, and Western/U.S. interests in the region. However, as Brazil develops its own offshore resources, Bolivia may lose opportunities to reap associated economic benefits.
} 
By 2015 Brazil was the seventh largest economy in the world, deployed troops in support of peacekeeping operations, and was a player of note on global debates concerning climate change and nuclear proliferation. Additionally, Brazil's domestic institutions are strengthening alongside an expanded middle-class and the eradication of critical hunger and poverty.

Every president in twentieth-century Brazil, particularly since Vargas, faced domestic and international constraints relative to global competition and internal order. Within the global order, the ability of Brazil to maneuver within or influence these constraints differs greatly when juxtaposed against other countries in the region and internationally.

\section{Brazil: Populism, Petroleum, and Neoliberalism}

\section{Economic Nationalism and Brazil}

Economic nationalism is not a new phenomenon, but is present in both old and new states. Additionally, states with a strong corporatist tradition are more likely to experience forms of economic nationalism. Harry Johnson (1967) provides a theoretical model explaining economic nationalism in new and developing states. Johnson's intention is to explain nationalist policies as rational and economic responses to specific situations. Nationalism is necessary to understand the ideological role of colonialism and imperialism in formerly colonial states.

Nationalism as an economic program often results in expropriation, the forced transfer of property from foreigners to nationals (i.e. nationalization of the civil service), 
or investment in the purchase of job opportunities for nationals. Nationalist economic policy fosters activities based on symbolic value, prestigious jobs for the middle classes, favors extensive state control (and public ownership) over economic enterprises, and social control over allocation of jobs for nationals. Under economic nationalism, lower economic classes are unlikely to gain.

Johnson (1967) asks why developing countries place great emphasis on substituting domestic production for imports despite indicators that economic efficiency is best served by the reliance on the principle of comparative advantage. Johnson next suggests there is a strong opposition to foreign capital investment and the employment of foreign scientific, technical, and managerial personnel - an attitude derived from nationalism. Johnson is correct in this last assertion. In the case of both Bolivia and Brazil, the governments responsible for the creation of their respective NOC were keenly aware of the need for technology and investment from independent oil companies (IOC).

Complementing Johnson, Thomas E. Skidmore (1967) argues no account of modern Brazilian politics can ignore how economic pressure has restricted the options available to the political elite. Choices presented to the elites are as delicate as they are unavoidable: agriculture/industrialization; foreign/private capital; regional imbalance/income distribution; and, accomplishing goals while managing inflation.

Peter Smith (1969) based his research into nationalism and the Brazilian petroleum industry on public opinion and national assumptions. Smith's definition of economic nationalism is like others' during related publications of that era and falls within the parameters of the definition used in Chapter One of this dissertation. Smith argues economic nationalism stresses the creation of an independent economy, citing the 
prime example as the 1938 expropriation of foreign companies' holdings by the Mexican government (Smith 1969, 2). Oil nationalism in Brazil began at the end of the First World War. Prior to 1918, oil exploration in Brazil was carried out unsuccessfully by private citizens.

Smith maintains economic nationalism is often considered the driving force behind less developed countries to accelerate their development through economic planning. In this context, Brazil pursued a policy of economic nationalism fearing threats to its independence and sovereignty posed by foreign capital exploitation. Among the wide range of economic nationalist variants, Brazil chose outright nationalization of its oil industry despite this choice being burdensome. Smith considered Brazil's choice foolish, and argues proponents of economic nationalism believed capitalism was not up to the task of industrializing Brazil.

Once placed into historical perspective, however, Brazil's choice to nationalize instead of relying on IOCs to develop and likely control the petroleum industry, was a necessary decision at the time. This decision was particularly essential in the context of the period. Because investment capital needed to come from Brazil, and such capital was scarce, it is not difficult to appreciate Brazil's complicated situation. Petrobras should be appreciated as both a product of and influence upon economic nationalism in Brazil.

\section{The Getúlio Vargas Era:}

To the economist, nationalism appears to be a driving force responsible for the acceleration of economic development. Nationalism is also responsible for economic policies not making much sense. As a direct example of applied nationalism, Getúlio 
Vargas (1930-1945, 1951-1954), the most substantial figure of twentieth century

Brazilian politics, made the political-emotional choice to nationalize Brazil's petroleum industry, and defeated the strictly economic arguments that it would be cheaper to have IOCs explore for petroleum and pay royalties to Brazil. Vargas was compelled to choose between industrialization and doing without manufactured goods. The worldwide economic depression greatly influenced this decision.

The worldwide depression that preceded Vargas is not the only factor at work during this period. From 1889-1930 (Brazil's First Republic), the concept of governance was that the republic should be orderly and bring with it progress (positivism). ${ }^{66}$ According to this interpretation, the republic should modernize, broaden its technical knowledge, and expand its communications. The only way for this to occur was to create a strong executive. Consequently, in the early 1900s, Brazil shifted its diplomatic attention from London to the U.S. in efforts to make Brazil the most important country in South America. The trigger for this political change was the price of coffee and related international markets (Fausto and Fausto 2014, 153).

The spread of coffee plantations in Brazil produced enormous harvests in the late $19^{\text {th }}$ century, the increased amount of coffee on the market led to a decreased price, and there was an associated drop in foreign exchange entering Brazil. Brazil then became unable to service its debts, and needed to renegotiate terms. Alongside domestic economic troubles, there was an emergence of worker social movements that appeared in

\footnotetext{
${ }^{66}$ Positivism was an ideology popular in Latin America from the 1870s through WWI. Largely drawing from the philosopher Comte, positivism was attractive for Latin America as it attacked the liberalism of John Locke and the U.S. as well as provided a basis for group rights, which were long a part of Latin American tradition (Wiarda 2001). The concept spread throughout the Army and linked many officers to Brazilian politicians.
} 
both rural and urban areas (Fausto and Fausto 2014, 159). ${ }^{67}$ These groups appeared and disappeared quickly. Ruling elites at the time rarely concerned themselves with such activity as political rights gained through activism were quickly rescinded once the pressure was off. Shortly thereafter, the combination of WWI revolutionary ardor in Europe and associated wartime inflation reached Brazil and ruptured the earlier social framework. Major cities faced large-scale worker strikes between 1917-1920. After the end of WWI, the urban middle-class became more publicly visible, and there was some support for liberalism among this group.

The breakdown of the coffee economy during the 1930s was the result of the ongoing world market crisis coupled with internal overproduction. The 1930 breakdown created favorable conditions for investment linked to internal markets, reducing Brazil's dependence solely on external markets, a development conundrum that exists today.

Brazil's economic breakdown and subsequent 1930 Revolution resulted from a confluence of events. The economic crash of October 1929 arrived amid heavily leveraged Brazilian loans alongside a drop in coffee prices. Expectations of guaranteed coffee profits did not appear as they were undermined by an associated decline in coffee consumption resulting from a lull in international trade. Brazil's experience was part of the worldwide framework of general economic and political instability (Fausto and Fausto 2014, 190).

\footnotetext{
${ }^{67}$ These social movements were categorized into three main groups that made attempts to organize and mobilize workers. The first group centered on religion and social needs; the second, religion and social justice; the third focused on social justice only (Fausto and Fausto 2014, 174).
} 
The oligarchic regime at that time was based on the axis between São Paulo and Minas Gerais states. Once this equilibrium was broken, there was a need for a new configuration of power. The old structure was based on coffee interests and could not survive. The 1930 Revolution resulted from a tacit agreement between the middle classes (lacking in political autonomy) and the traditional sectors (less linked to exportation); however, the bases of the new power structure could not be firmly established. The political representation of coffee interests was upset, but coffee remained the decisive basis of the economy (Weffort 1966, 187). Coffee maintained a prominent place among Brazilian exports until its steep and steady decline in the middle-1960s (see Graph 33, below).

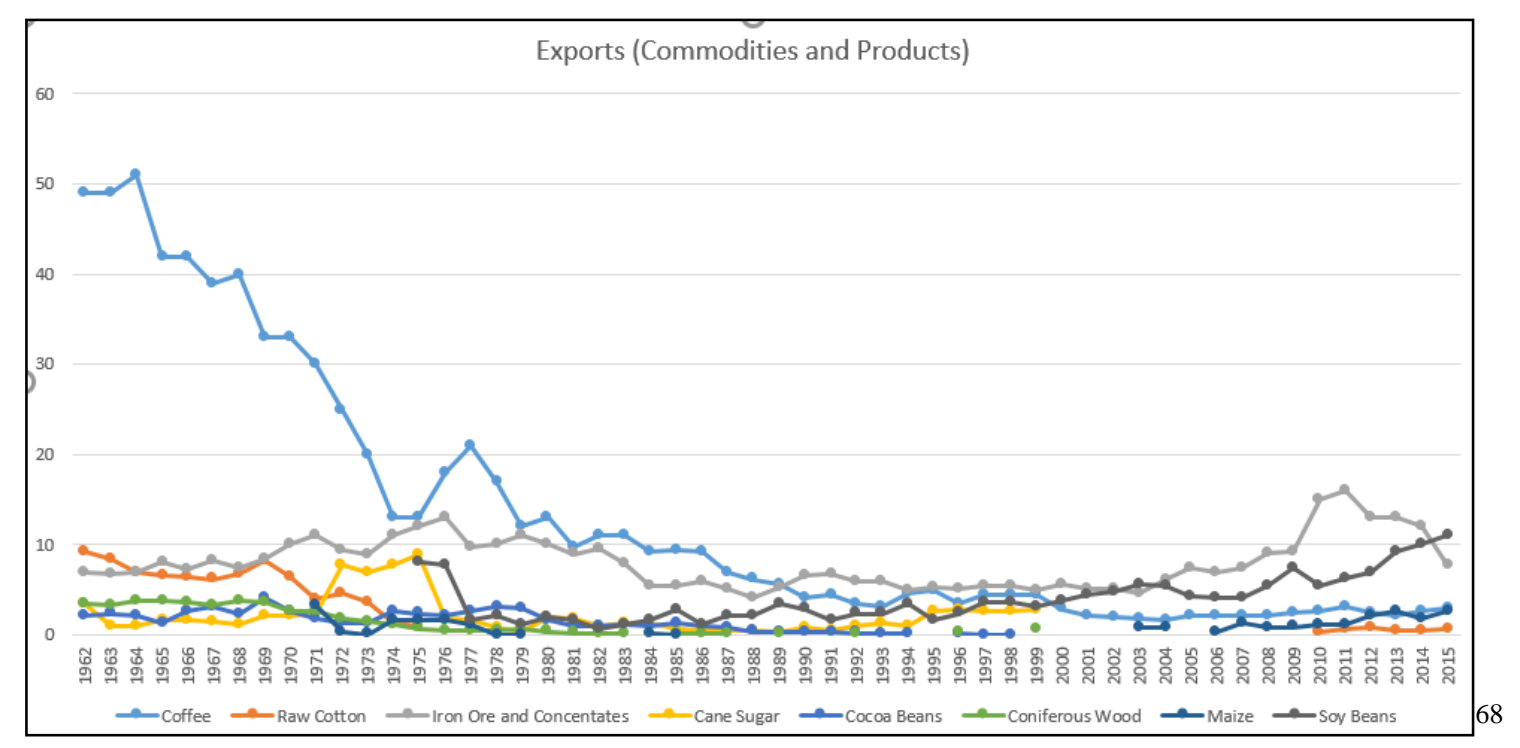

Graph 33: Brazil Exports (Commodities and Products)

${ }^{68}$ MIT. The Observatory of Economic Complexity. http://atlas.media.mit.edu/en/. Accessed 14 January 2018 . 
A heterogeneous group produced the 1930 Revolution as traditional oligarchies fell from power and were replaced by military men, technocrats, young politicians, and industrialists. A new kind of state emerged, which was increasingly centralized and with greater autonomy. Getúlio Vargas promoted national capitalism from a combination of the state apparatus itself and the industrial bourgeoisie alliance with the urban working class (Fausto \& Fausto 2014, 191).

The appearance of Getúlio Vargas as a political force was a consequence of the collapse of the political arrangement that had lasted to 1930. Brazil's 1930 Revolution had two central characteristics. First, there was the weakening of the oligarchic state, which was agricultural and export oriented. Second, there was the formation of a democratic state based on the urban masses and industrial social sectors. It was during this period that Brazil initiated its transition from a limited to a wide participation democracy (Weffort 1966, 187).

The urban middle classes were the most important pressure groups for overthrowing the oligarchy, and included public officials, military men, and liberal professionals. 1930 was the climax of the political pressure extended by the urban middle-class. During the ensuing post-oligarchic crisis, the middle-class was unable to establish a democratic regime based on their liberal aspirations. Despite dominance in opinion and action, the middle classes lacked the social and economic means to reject the institutional framework (Weffort 1966, 187). This was not a situation unique to Brazil. ${ }^{69}$

\footnotetext{
${ }^{69}$ In most Latin American countries, the traditional middle class did not satisfy social and economic conditions that allowed for political autonomy away from the interests of the large agricultural estates (Weffort 1966, 188).
} 
Upon ascension to power, Getúlio Vargas approached short-term problems of the economy with a mixed policy. Vargas was required to manage the external balance of payments against internal inflation with the orthodox adherence to the traditional rules of the international economic system. Internally, however, Vargas developed a system of government-coordinated investment. The creation of the National Bank for Economic Development (BNDE; later renamed by inclusion of a "social" element, BNDES) was intended to help develop the Brazilian economy soften the orthodox approach with a strategy of economic nationalism. Vargas deeply distrusted foreign capital, and his antiimperialist message offered him a link to left-wing intellectuals and notions. Vargas' version of economic nationalism was aggressive.

Such aggressive nationalism fit well with Vargas' development plans, and in 1951 he submitted a bill for the creation of Petrobras, over a decade after oil was discovered in Brazil. The concept of the parastatal stressed the need for state corporations as an instrument of policy. Moreover, public opinion at the time favored a nationalist solution to the oil question, and moderates supported the idea as oil arguably required a separate policy. Carefully balancing the above with the external exigencies of the market, the Petrobras proposal attempted to ease the pain of Brazil's balance of payments (Weffort 1966, 194). Imports consumed foreign exchange, and to substitute imported for domestic oil would benefit Brazil in the long-term.

Turning briefly away from the Vargas era specifically, we find Petrobras is a particularly successful NOC. Today Petrobras is a leader in deep-water oil exploration and production, dominant in the Brazilian oil and gas market, and has an albeit small but growing presence abroad. Petrobras began with no meaningful reserves or expertise in 
the oil business, and unlike other NOCs, Petrobras was not initially created by the government to be a revenue source or jobs program. Initial scarcity of revenue forced Petrobras to select projects rationally to guarantee positive cash flow. The government goal was to save scarce currency, and to provide a competitive and secure fuel supply to industrialize Brazil. Petrobras accomplished this through vertical integration and exploiting economies of scale, and by 2008 Brazil emerged as a net exporter of oil (Victor et al 2012, 540). As demonstrated by Graph 34 below, crude oil became a greater percentage of Brazil's exports than its once main product, coffee.

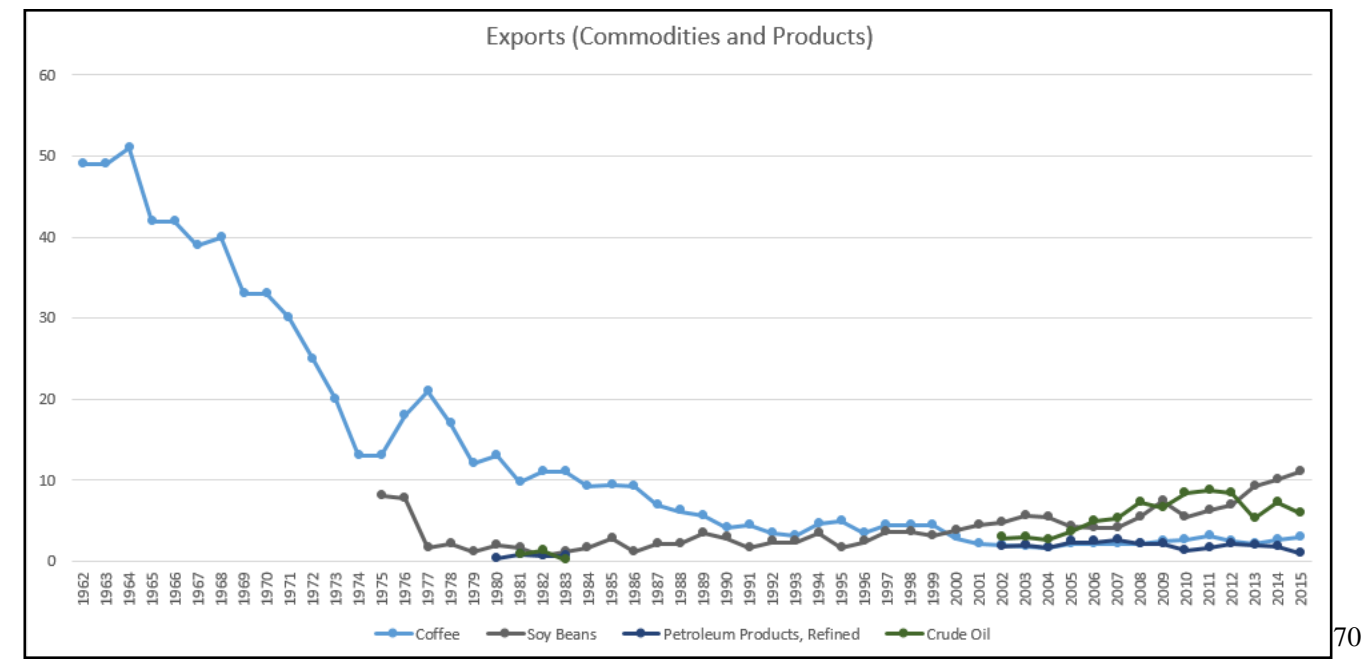

Graph 34: Brazil Exports (Commodities and Products)

As Brazil moved towards nationalism and its associated greater economic autonomy, social tensions surfaced, particularly among the traditional sectors and elites. As the import-export sectors feared a loss of social status and importance, an emotional appeal to economic nationalism was dangerous as these ideas were associated with a

${ }^{70}$ MIT. The Observatory of Economic Complexity. http://atlas.media.mit.edu/en/. Accessed 14 January 2018. 
restructuring of the Brazilian economy. As evident in contemporary Brazil as it was during the Vargas era, economic nationalism could be useful to construct public consensus, but it could be equally dangerous as it could deepen social, economic, and political divisions.

Such dangers of nationalism, particularly economic nationalism, are not exceptional; however, how they manifested themselves in Brazil is rooted in the country's unique history. Brazilian nationalism specifically may be traced to Europe, particularly Portugal, and this sentiment has a long history of development. Brazil had all the characteristics that historically favored the formation of strong nationalism. ${ }^{71}$

Brazil did eventually experience its own nationalist development, which has been periodized into three distinct eras. ${ }^{72}$ The most recent period of Brazilian nationalism arrived in the late-nineteenth and early-twentieth centuries, and is further divided because of the systemic instability of two world wars and associated economic crises. Economic nationalism came into play during the Vargas era whereby nationalism became an instrument for change and was considered crucial for Brazilian development. During the long Vargas era, Brazil drew from Iberian traditions of patrimonialism, balanced competing groups, and softened some conflict in the country. These Iberian traditions were subsequently converted into a form of 1950s technocracy (Wirth 1970, 12).

\footnotetext{
71 The unity of territory, a shared desire to settle its interior, a language different to that of the rest of Latin America, a Roman Catholic majority, and shared ideological preferences are the most salient characteristics. That Brazil remained under a monarchy while its neighbors endured republican revolutions is a defining political difference (Burns 1968, 6).

72 The first period (Colonial Nativism) developed during the $16^{\text {th }}$ through $18^{\text {th }}$ centuries, reflected colonists' love and pride in the land, and was not necessarily antagonistic towards Portugal. The second period (Defensive Nationalism) came during the $19^{\text {th }}$ century, and was a period of increased awareness that Brazil differed from other countries, particularly from Europe and its Spanish-speaking neighbors (Burns 1968, 9).
} 
However, populism, arguably, was the thrust in Brazil between 1930 and the military takeover in $1964 .^{73}$

During the first Vargas presidency (1930-1945), the desire was to increase Brazilian exports where it had both a cost and geographical advantage. The goal was to keep up with debt payments, and cover imports. Vargas in his second presidency (19511954) greatly encouraged state planning to develop power resources, with Petrobras being the most salient (Wirth 1970, 10). Additionally, during the Estado Nôvo period, the Brazilian Army emerged as the main engine of economic nationalism, the ideology later taken up by Vargas' technocrats.

Nationalists of the time argued that Brazil could only become truly independent through economic development. This feeling was the zeitgeist across Latin America. The region became increasingly hostile towards, or resentful of, foreign capital, was suspicious of private enterprise, and there was also a growing preference for state ownership while simultaneously encouraging industrialization well beyond the production of key industry (i.e. non-durable consumer goods, durable goods, steel, power, oil). The Vargas era marked a definitive shift from cultural to economic nationalism in Brazilian history. ${ }^{74}$

\footnotetext{
${ }^{73}$ Vargas adopted the populist strategy after he had already been in power for over a decade and carried in this direction until 1945 when the military forced him from office. Later and similarly, João Goulart was president for roughly two-and-a-half years before adopting populist discourse, which resulted in him being deposed by the military in 1964 (Bethell 2013, 77).

${ }^{74}$ Economic nationalism is not solely a result of Getúlio Vargas, but has deeper roots in the nineteenth century writings of Alberto Tôrres (1865-1917), in which economic development was equated with nationalism.
} 
A major test of Vargas' skill is seen in the response to the long-term fall in coffee prices ( 1930-45), when Vargas simultaneously adopted two solutions: the need to diversify the economy away from a single commodity, which varied over time (i.e. Brazilwood; sugar; gold; coffee); and, to accelerate industrialization (Burns 1968, 74). Greatly attributable to Vargas' actions, by the mid-twentieth century Brazil was the most industrialized country in Latin America, which revolutionized Brazilian life and challenged the traditional social structure. Of course, the great symbol of economic nationalism for Brazilians, and all Latin Americans, was petroleum (Burns 1968, 76). Although Vargas and other leaders of that era saw the need to diversify away from a commodity-driven economy, Brazil and Latin America have returned to this model in recent years.

Ultimately, the first Vargas period would collapse; this happened alongside the conclusion of the war against fascism. The end of fascism united the large urban sectors, and appeared to indicate the beginning of democracy, a dream of Brazil's urban classes since the 1920s. After 1945, the political participation of the urban masses acquired greater importance than what was foreseen in the dictatorship as populist leaders emerged and won national elections. Nationalism then became politically significant when the federal government adopted it as the ideological justification for development policy (Weffort 1966, 191).

There was a prevailing belief in Brazil, as remains largely the case worldwide today, that oil is an economically desirable export, which may project countries to at least regional power prestige. During Vargas' second administration (1951-1954) he exploited oil as a symbol for wider political support. During this period, Vargas proposed the 
creation of Petrobras. ${ }^{75}$ Vargas replicated the European nationalists' success of the 1930s to strengthen Brazil's national government through the use of institutions and state power to further nationalist goals. Vargas set the foundation to drive the course of Brazil's

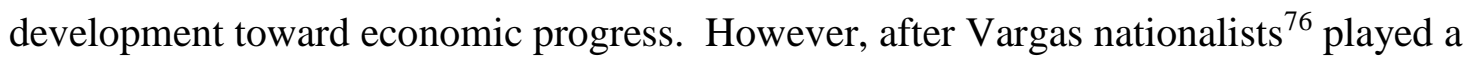
more assertive role in the government, the military became increasingly suspicious of their agenda, and ultimately seized power in $1964 .^{77}$

Nationalism is a potent force which cannot be suppressed eternally, and resurfaces throughout contemporary Brazil, often flirting with populism. However, industrial development depends greatly on foreign capital investment. Thus, the creation of a policy independent of foreign interests is inherently incongruous. Echoes of the 1930 Revolution were felt for decades, and the continuity of mass democracy from 1945 until the fall of João Goulart in 1964 results from the persistence of these structural conditions.

\section{Waning Populism and pre-Dictatorship in Brazil:}

The term populism is an abstract concept and difficult to define. ${ }^{78}$ What follows below is a cursory review of populism, and its manifestation in Brazil during the

\footnotetext{
${ }^{75}$ After two years of congressional wrangling, the creation of Petrobras was approved in 1953. Today, Petrobras remains the single enduring achievement of the Brazilian nationalists.

${ }^{76}$ The nationalist movement was a very diverse group (from the left to right along the political spectrum), and included intellectuals, students, the urban proletariat, middle class, and elements of the military and industry (Burns 1968, 93).

${ }^{77}$ After Vargas, Brazilian nationalism took on four central characteristics: 1) The political Left took over the leadership of the movement; 2) Nationalist leaders became increasingly critical of foreign economic influence, which led to 3) Brazil's strongest attack focused on the United States; 4) Economic nationalism was the only way to liberate Brazil from its past and project the country into the future (Burns 1968, 78).

${ }^{78}$ For a detailed examination of populism in Latin America, please refer to the literature review in Chapter One.
} 
twentieth century. In its simplest form, populism is best understood as a political phenomenon that encompasses parties or movements. These parties or movements are often embodied in one individual, who is able to reach power through identification with previously excluded or marginalized sections of the population. These historically marginalized populations are mobilized from above, or through identification with someone who shares their historical experience.

Populism is heavily associated with Import Substitution Industrialization (ISI) in Latin America; however, the former is not always tied to the latter. ${ }^{79}$ A country that adopts economic nationalism usually relies upon ISI for its industrialization program (Smith 1969, 2). It is the overlap of the concepts of populism and economic nationalism that drive much of this dissertation. In the case of Brazil, ISI was evident in the 1930s, but populism did not emerge until Vargas' second term (1950s). Most scholars argue populism emerges in a country during times of crisis such as a transition to modernity, a crisis of export-led development, or concomitantly with a state-centric developmental model (De La Torre 2013, 8). That this crisis came on the heels of the 1930 Revolution in Brazil is not surprising.

After Vargas' fall and associated instability in Brazil, the Jucelino Kubitschek (1956-1961) years were considered politically stable, but not entirely ideal. Under Kubitschek (JK) the economy demonstrated solid economic growth, and the military favored the backing of democratic governments; however, some limits remained to counter the communist threat (Fausto and Fausto 2014, 247). Ironically, although some

\footnotetext{
${ }^{79}$ For a succinct definition of Import Substitution Industrialization, please see Chapter One.
} 
nationalist officers preferred communism, others desired democracy despite supporting the idea of a coup to renovate Brazil's institutions in attempts to weaken trade unions and communists.

The Kubitschek program promoted state intervention in the economy in the form of direct aid, and seeking foreign capital investment; attention centered on six important sectors to include energy, transportation, and basic industry. During the JK era, nationalism lost some ground, and the president's troubles occurred where foreign trade and government finance overlapped. Increased spending on industrialization and the founding of the new capital in Brasilia weakened the exchange rate and led to growing federal budget deficits, which combined with inflation (Fausto \& Fausto 2014, 252). Essentially, JK pushed forward with industrial production amid lagging development in the Brazilian northeast. Although Kubitschek maintained the economic program, he ultimately severed with an International Monetary Fund (IMF) plan and left the country's economy in shambles. Despite the collapsing economy, Kubitschek entered and left power peacefully.

After JK ended his term, Jánio Quadros carried out a brief presidential stint; he resigned after seven months in office. Quadros lacked a support base, and alienated both the political left and the right. During this compressed period, Quadros pursued an orthodox economic stabilization plan; international creditors appreciated his actions while Brazilians suffered (Fausto and Fausto 2014, 257). Quadros was succeeded by Vice-president João Goulart in a curious turn of events.

Although constitutionally president, João Goulart's (1961-1964) ascension to power was blocked by Quadros' military ministers in the name of national security. The 
military believed Goulart represented trade-unionism, which at the time was considered a way for communists to enter power. Ultimately Congress adopted a compromise;

Goulart would become president, but would rule in a Parliamentary system with diminished power. After taking office in 1961, Goulart signaled a return to populist policies, and as a result lost some of his legitimacy (Fausto and Fausto 2014, 271). ${ }^{80}$ What is ultimately important during this period is that populists were cast aside as the military took power in 1964.

Military Rule and Dictatorship (1964-1985):

Many greeted the 1964 military takeover of government with enthusiasm including the media, most sectors of the Catholic Church hierarchy, and the political elite. Beginning in 1964, a coalition of generals desired to change the state as well as society; fear of communism among the political right largely drove this activity. The desire to change state and society was encapsulated in what would later be defined as a national security regime. ${ }^{81}$ However, it is important to clarify here that centralized control of Brazil did not happen overnight. In fact, it is commonly held that since the 1930s the Brazilian military increasingly began to occupy the function of a moderating force

\footnotetext{
${ }^{80}$ Populism in the region is not limited to nationalism, and has emerged during periods of neoliberal reform. Countries in the region such as Peru under Fujimori, Argentina under Menem, and Ecuador under Bucaram experienced such transitions during the period of neoliberal economic reform known as the Washington Consensus (Demmers et al 2000). In the case of Brazil, this form of populism took place initially under the leadership of Fernando Affonso Collor de Mello (1990-1992), who will be discussed later in this chapter.

${ }^{81}$ National Security Regimes were intent on national economic growth in a controlled environment, but were later discovered as being guilty of repressing human rights. This period was not isolated to Brazil, but represented a trend in the region at the time.
} 
through the centralization of power, thus reconditioning the state as guarantor of private and public negotiations (Faoro 1958, 236). ${ }^{82}$

Prior to the Vargas era, Brazil lacked a history of personalistic dictators; however, the national security regime model changed Brazil from the politics of personal clientelism to that of institutional and bureaucratic military rule. Additionally, similarlyminded countries adhering to this concept coordinated their actions in efforts to eliminate dissent among Southern Cone countries. ${ }^{83}$ This version of the Brazilian state rewrote the constitution, ultimately ratified by Congress in 1967 (Meade 2010, 164). Although the military ruled, its generals searched for a political base amid growing opposition and growing repression (1964-1967). Opinions differed between moderate and hardline elements in the military with the former allowing some public opposition; however, hardliners wanted to control the students and workers alike. Ultimately, military hardliners took the upper hand and imposed a series of Institutional Acts (AI). ${ }^{84}$ The aim of the AIs was to change Brazil's institutions. The first AI in April 1964 preserved (with some modification) the constitution of 1946. Under this AI, Congress would continue to meet, parliamentary immunity was suspended, and there was some curtailment of

\footnotetext{
${ }^{82}$ Raymundo Faoro, one of Brazil's greatest jurists, describes state involvement in the economy through the creation of the National Department of Coffee in the early $20^{\text {th }}$ century; the later creation of Petrobras maintains this tradition. Although Petrobras' creation took place a few years prior to the publication of Faoro's work, the proximity in time of events likely precluded the inclusion of the parastatal in his analysis (Faoro 1958). Despite Faoro not speaking directly to the creation of Petrobras in his work, the similarities are palpable. Essentially, economic liberalism in Brazil has a short history.

${ }^{83}$ For example, Operation Condor was a secret alliance among dictatorships in South America during the mid-to-late 1970s, which included a Southern Cone rendition and repression program designed to locate and eliminate opponents of military regimes in the region.

${ }^{84}$ According to Fausto and Fausto (2014), Institutional Acts (IA) were a series of acts passed by the military government during the long dictatorship. The military implemented IAs to alter Brazil's institutions, and justified these acts as a consequence of exercising power, which the military claimed was an inherent component in all revolutions.
} 
peoples' rights. Although not purely authoritarian, rights were clearly not completely maintained. The press was controlled, the right of habeas corpus was not consistently preserved, the military government persecuted its enemies through arrest and torture, and many people were killed.

Under the military dictatorship (1964-1985), economic policy in Brazil was based on a hybrid strategy. This strategy was essentially an alliance among the state, foreign and national private capital, and agricultural commodities (Petras 2013, 470). The foreign and national capital was industry export based, and as aforementioned that of agriculture mostly comprised of coffee. Ultimately, this model provided a foundation for the subsequent anti-dictatorial struggle and the return of democracy as neoliberal policies were in the ascendant. It must be noted here that despite repression in the political realm, the military experienced success in economic policy, which led to a vigorous industrial recovery in 1968.

Succinctly, from 1964 until the return of democracy the military took power and ran the government; however, it rarely acted as a political bloc. The dictatorship was not a personal one as during the first Vargas era; instead, military leadership after 1964 simply exchanged power. Although Congress approved the ARENA-nominated president, it simply sanctified military decisions. ${ }^{85}$ The truth of the matter is that Congress was an unimportant body. Professional politicians were no longer in charge. Nevertheless, the military did not govern alone, but offered leverage to individuals regarding the formulation of economic policy. Also different from the Vargas era was

\footnotetext{
${ }^{85}$ The National Renewal Alliance (ARENA) was a pro-government party during the military dictatorship (Fausto and Fausto 2014, 302).
} 
that populism ceased to be an important means of attaining power despite the state maintaining a significant role in running the economy (Fausto and Fausto 2014, 302).

Upon the conclusion of the military dictatorship, the voting franchise expanded to include illiterates, and all political parties were then made legal. At the beginning of the 1980s, Brazil had the most closed economy in the capitalist world. The closed nature of the economy was a direct result from the 1950s industrialization model, and worsened because of the 1980s external debt crisis.

In 1980, after roughly two decades of dictatorship, the process of Brazilian democratization began, was turbulent, and culminated with a transition to civilian rule in 1985. The first post-dictatorship president, Tancredo Neves died in 1985, and was replaced by his Vice-President Jose Sarney. After Sarney completed his term in 1990, the result was the first directly-elected president since the dictatorship, Fernando Collor de Mello (1990-1992). Amid this transition to democratic rule came some of the politics of the old populists.

Collor de Mello ran a simple populist program and denounced traditional elites as well as public and private sector corruption; he defeated Lula in 1989. However, despite his populist and anti-corruption rhetoric, the Collor de Mello government drowned in a corruption scandal, resulting in his impeachment, removal from office in 1992, and stripping of political rights. Amid this shift towards democracy was the additional challenge of navigating a new and complex constitution (1988) concomitant with bouts of inflation (200\% in 1985; 400\% in 1987; 3,000 in 1990), as demonstrated in Graph 35, below. 


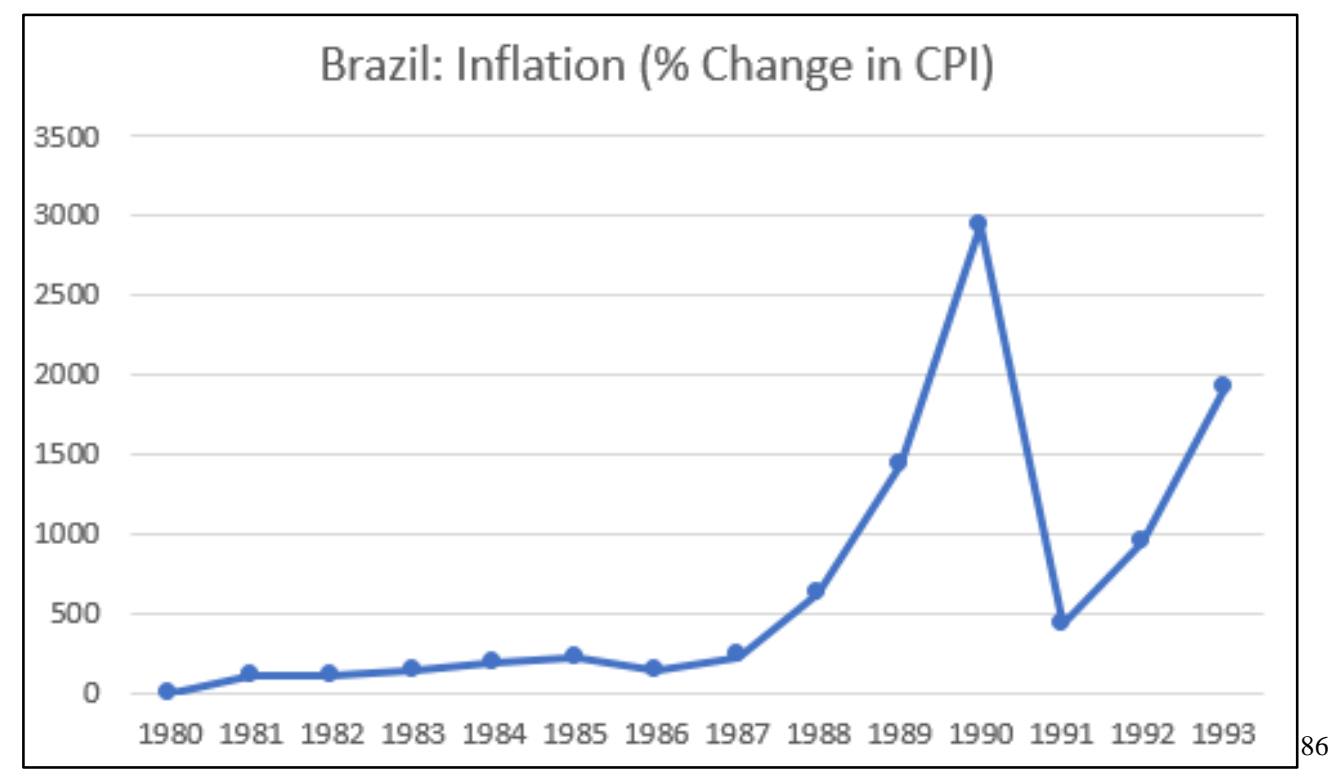

Graph 35: Brazil Inflation (\% Change in CPI)

The electoral opposition that succeeded the military regimes was initially polarized between the liberal, free-market, and agro-mineral elite and a worker-peasant, rural-lower-middle class nationalist bloc (see Table Two, below). The parties involved were those of militant labor that formed the CUT, and landless peasants that formed the MST. The CUT and MST, along with many intellectuals and artists, joined the middleclass to form the PT (Petras 2013, 471). The decade following the dictatorship (through 1994) was characterized by tension between lingering state capitalism and an emerging liberal, free-market bourgeoisie. It was during this time that Fernando Henrique Cardoso (FHC), the former leftist, reinvented himself and became Brazil's main free-market evangelist.

${ }^{86}$ The Global Economy. http://www.theglobaleconomy.com/. Accessed 14 January 2018. 


\begin{tabular}{|c|c|c|}
\hline \multicolumn{3}{|c|}{ Brazilian Political Parties mid-1980s ${ }^{87}$} \\
\hline Left/Center-Left & Center/Center-Right & Center-Right/Right \\
\hline $\begin{array}{l}\text { PT (Workers' Party): } \\
\text { Formed 1980; industrial } \\
\text { worker base; brought } \\
\text { together trade unionists } \\
\text { (CUT party), some leftists, } \\
\text { and a handful of } \\
\text { Trotskyists; first major } \\
\text { authentic socialist party }\end{array}$ & $\begin{array}{l}\text { PMDB (Brazilian Democratic } \\
\text { Movement Party): founded in } \\
\text { opposition to dictatorship; } \\
\text { internal split between } \\
\text { moderates and leftists in mid- } \\
\text { 1980s; some elements went to } \\
\text { PSDB }\end{array}$ & $\begin{array}{l}\text { PFL (Liberal Front } \\
\text { Party): Formed 1984; } \\
\text { center-right; } \\
\text { subsequently joined AD } \\
\text { party (later withdrew), } \\
\text { and supported PSDB } \\
\text { candidate Cardoso }\end{array}$ \\
\hline $\begin{array}{l}\text { PSDB (Party of Brazilian } \\
\text { Social Democracy): } \\
\text { Center-Left; strong among } \\
\text { middle-class and non- } \\
\text { radical leftist intellectuals; } \\
\text { Cardoso's party }\end{array}$ & $\begin{array}{l}\text { PSD (Social Democratic } \\
\text { Party): Formed in } 1945 \text { as } \\
\text { part of the state political } \\
\text { machine; split later to form } \\
\text { ARENA }\end{array}$ & $\begin{array}{l}\text { ARENA (National } \\
\text { Renewal Alliance): } \\
\text { Formed by dictatorship } \\
\text { in } 1965 \text { as pro- } \\
\text { government party; } \\
\text { comprised of many } \\
\text { from PSD }\end{array}$ \\
\hline
\end{tabular}

Table Two: Brazilian Political Parties, mid-1980s

Democratic Aperture, Cardoso, and the Real Plan:

The transition from military dictatorship to an incipient democracy was not an overnight event, but resulted from increasing pressure on the military governments to accept that their rule could not legitimately endure much longer. The military, partly by its own design, and partly through external forces, concluded that as an institution it needed to voluntarily leave politics before it was forced back into the barracks through a confluence of political and economic pressure.

Taking a regional reflective approach, Scott Mainwaring (1995) centers on four issues relative to the achievements and failures of the then new democracies in Brazil and the Southern Cone: economic performance; effectiveness in addressing poverty and

${ }^{87}$ For a description of Brazilian political parties at the time, see Petras (2013). 
inequality; quality of democratic practice; and, popular support and legitimacy. In the case of Brazil, Mainwaring argues the great achievement of democracy in the region is its survival (Mainwaring 1995, 131). Nevertheless, despite the military regimes' problems in Brazil, they were more successful than other countries in the Southern Cone that had similar experiences. Although not discussed in Mainwaring's study, the Brazilian military governments were more successful than those of neighboring Bolivia as the former oversaw rapid modernization and industrialization with more success than the latter.

After the military dictatorship came to an end, president Jose Sarney’s (19851990) Cruzado Plan (a heterodox economic stabilization plan implemented in 1986), held early promise; however, it led to economic imbalances in the country. Sarney ignored these problems because he benefitted politically from the plan's initial success. Later he adjusted, but the delayed action took a heavy economic toll on Brazil (Mainwaring 1995, $133)$.

By this point the Brazilian economy was again on the rocks, and this reality discredited both political parties. The discrediting of the traditional parties arguably led to the 1989 election of political outsider Collor de Mello. Collor's stated platform was to lead Brazil towards economic neoliberalism with some inbuilt societal protections; however, it is likely his model included a greater role of the state in the economy than orthodox neoliberals wanted (Mainwaring 1995, 135). Despite Collor's attempts resulting in some drops in inflation, Brazil's macroeconomic performance remained poor. Moreover, during his tenure, Collor implemented a neoliberal agenda that did little to improve the condition of those who elected him into office. 
As will be clarified in a separate section of this chapter, unlike Collor, Lula (a populist of the left) accepted challenges that resulted in a net benefit for the people responsible for his election. In Lula's case, the establishment of anti-poverty programs and redistributive social policies endeared him to many Brazilians. However, a worrying concern with populism remains potential erosion of state institutions, and that inevitable transitions away from populist rule are messy and sometimes dangerous.

Itamar Franco (then Vice-president) succeeded Collor after a corruption-related impeachment. ${ }^{88}$ Franco wavered between populist expansion and stabilization policies. It was during this period that Fernando Henrique Cardoso (then Finance Minister) introduced a new stabilization plan that controlled inflation and allowed the economy to expand.

Cardoso as Finance Minister was charged with the thankless task of improving Brazil's finances. His Plano Real (named for the new currency) was an attempt to confront inflation amid the introduction of a new currency while simultaneously implementing mild austerity. The plan was a success relative to controlling inflation and resulted in a vertiginous rise in Cardoso's popularity. Though, austerity created serious domestic problems including increasing inequality. Cardoso became a major political contender in the 1994 election in the face of his historic leftist critique of the government.

\footnotetext{
${ }^{88}$ Collor de Mello's impeachment brought an end to the political crisis without the involvement of the military (Collor was tried and convicted by the Senate). The investigation revealed the enormity of the corruption scandal, even by Brazilian standards, as media and congressional investigations discovered deals at the highest levels of government. The scandal and subsequent resolution demonstrated Brazil had a free press, unlike in the past; moreover, in the opinion of many, it placed the Brazilian justice system above that of the U.S.
} 
Despite his leftist tendencies, Cardoso, like many others during this period in Latin America, converted to neoliberalism. It is important here to note that both Cardoso and Lula, as well as Lula's handpicked successor Dilma Rousseff, politically developed under opposition to military rule. The elites distrusted Cardoso because of his leftist past; however, preferred him to Lula. Cardoso was reelected in 1998, constitutionally barred from seeking a third term, and left office peacefully in 2002 with very low approval rates.

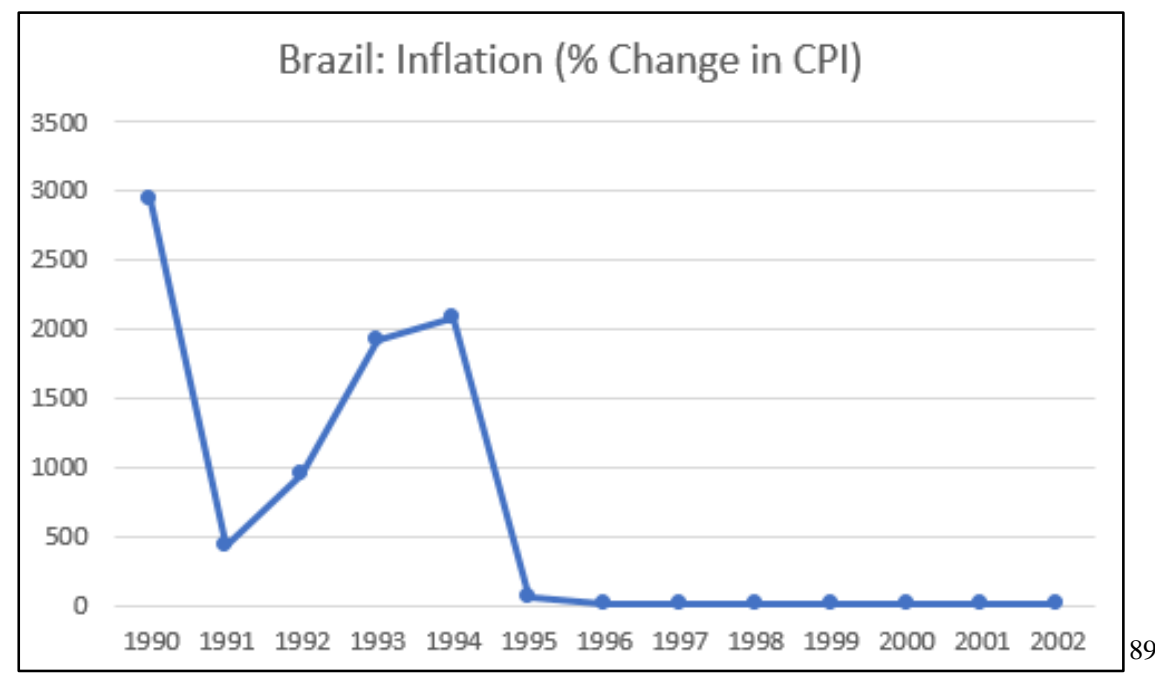

Graph 36: Brazil Inflation (\% Change in CPI)

Brazil experienced what was one of the most impressive socio-economic reversals in modern history, as it moved from a nationalist-industrialist economy to one of primary exports. After the 1964 military coup, the balance changed in Brazil relative to national and foreign capital, with the latter accelerating after the electoral change in the mid1980s. By the time Cardoso left office in 2002, inflation was largely under control (see Graph 36, above). The election of neoliberal politicians such as Cardoso arguably

${ }^{89}$ The Global Economy. http://www.theglobaleconomy.com/. Accessed 14 January 2018. 
affected the strategic sectors of the national economy as privatization accompanied some denationalization. Cardoso's economic liberalization policies were successful in controlling inflation, but denationalized Brazil's industry and affected strategic sectors that were the engine for growth. Moreover, Cardoso laid the groundwork for a massive inflow of foreign capital investment (see Graph 37, below).

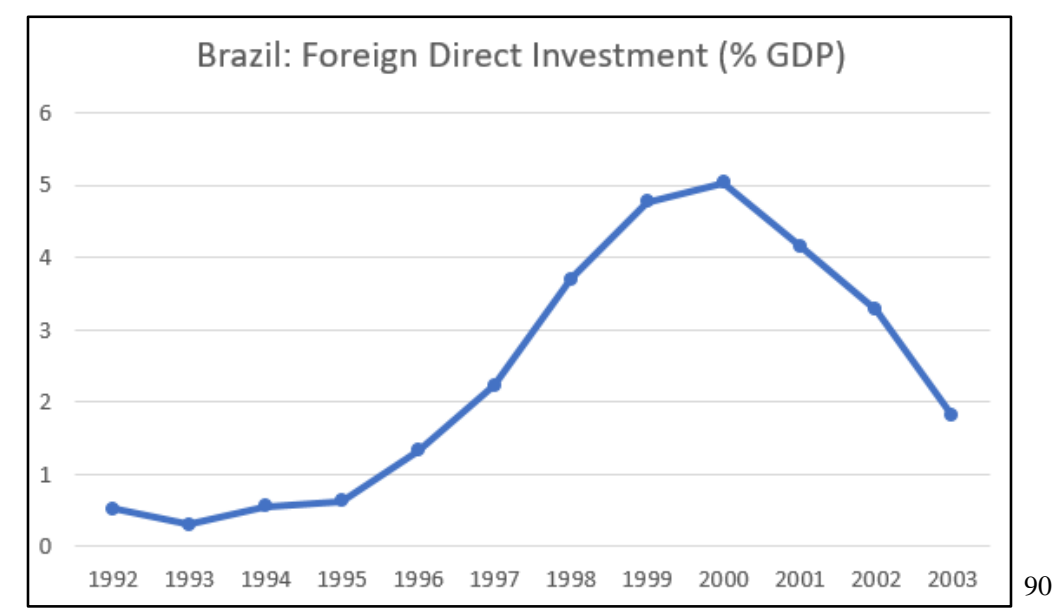

Graph 37: Brazil Foreign Direct Investment (\% GDP)

After a decade or so of distance from the military to democratic transformation, Peter Kingstone (2000) explains how Brazil exceeded observers' expectations through the incremental extension of reforms; however, challenges remain. The most salient challenge is the formulation of a clear economic policy, particularly concerning currency (Kingstone 2000, 187). For example, if the currency or economy becomes unstable, foreign capital may flee, likely causing substantial shock (i.e. inflation; balance of payments problems). Shocks may compel the government to alter an already unclear policy. Present-day Brazil may be experiencing this exact scenario as it returned to

${ }^{90}$ The Global Economy. http://www.theglobaleconomy.com/. Accessed 14 January 2018. 
commodity exports as its central economic driver. The return to a commodity-based model happened because commodities were growing, and because the government lost its ability to run an industrial policy. With most businesses becoming foreign owned, Brazil essentially lost control over its industrialization. Nevertheless, unlike the mid-twentieth century, Brazilian exports are not limited to raw materials alone (see Graph 38, below).

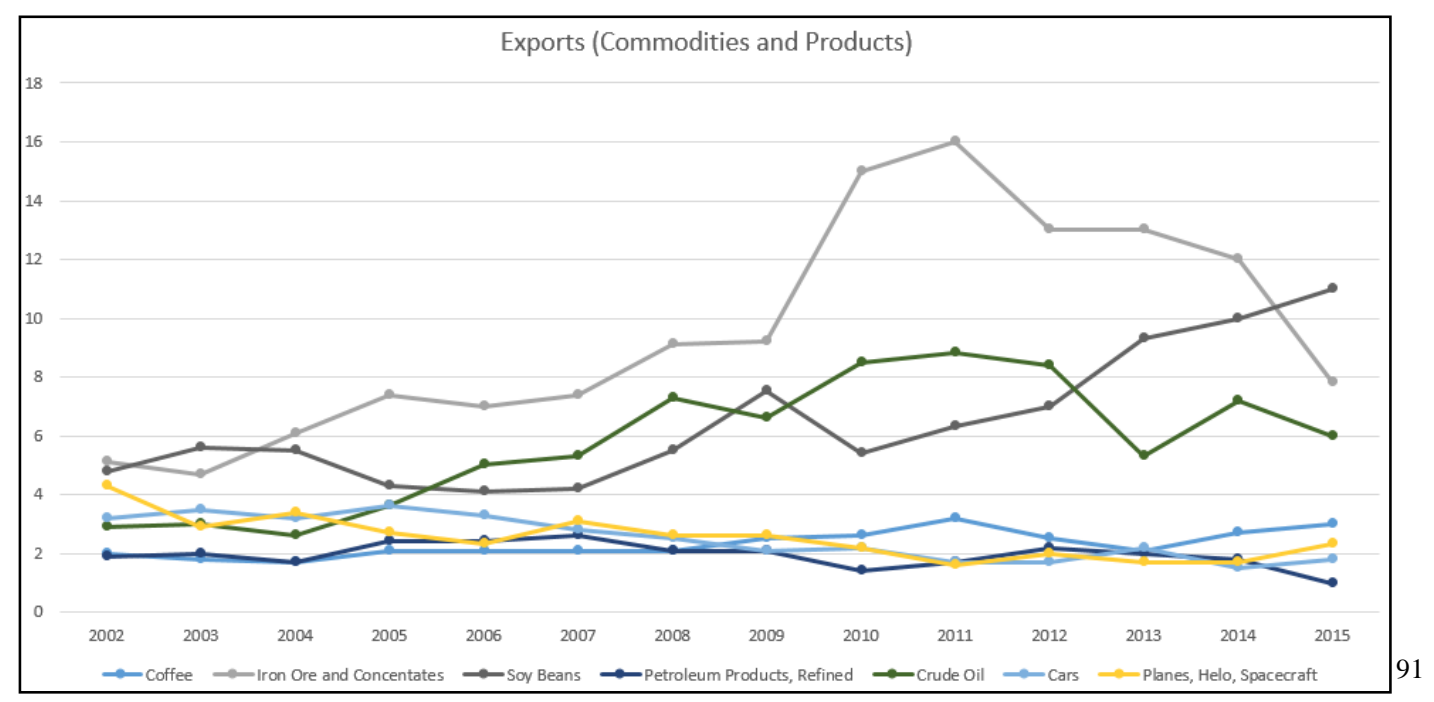

Graph 38: Brazil Exports (Commodities and Products)

There is clearly an export shift away from agriculture to manufacturing (see Graphs 39 and 40, below).

${ }^{91}$ MIT. The Observatory of Economic Complexity. http://atlas.media.mit.edu/en/. Accessed 27 May 2018. 


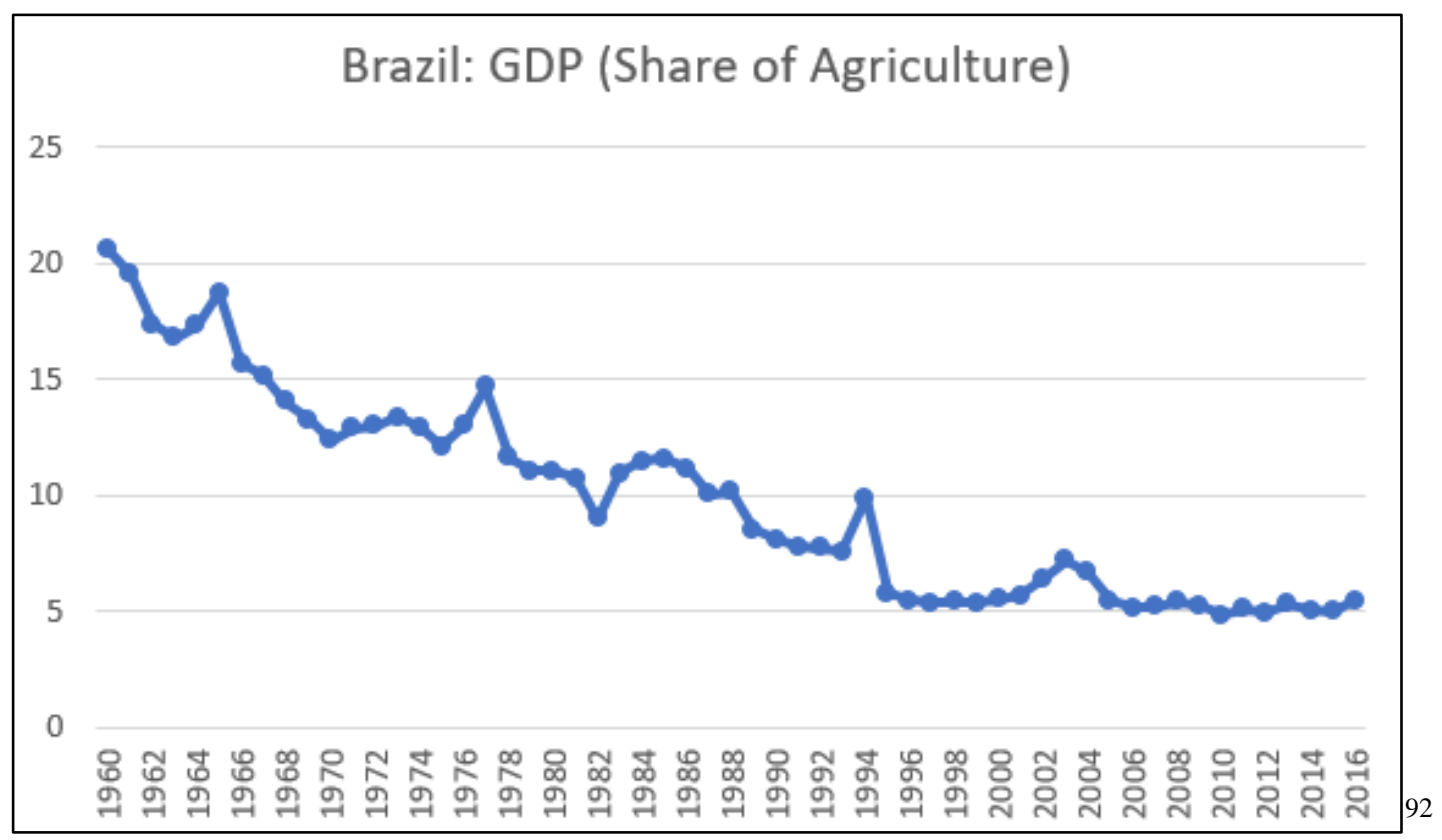

Graph 39: Brazil GDP (Share of Agriculture)

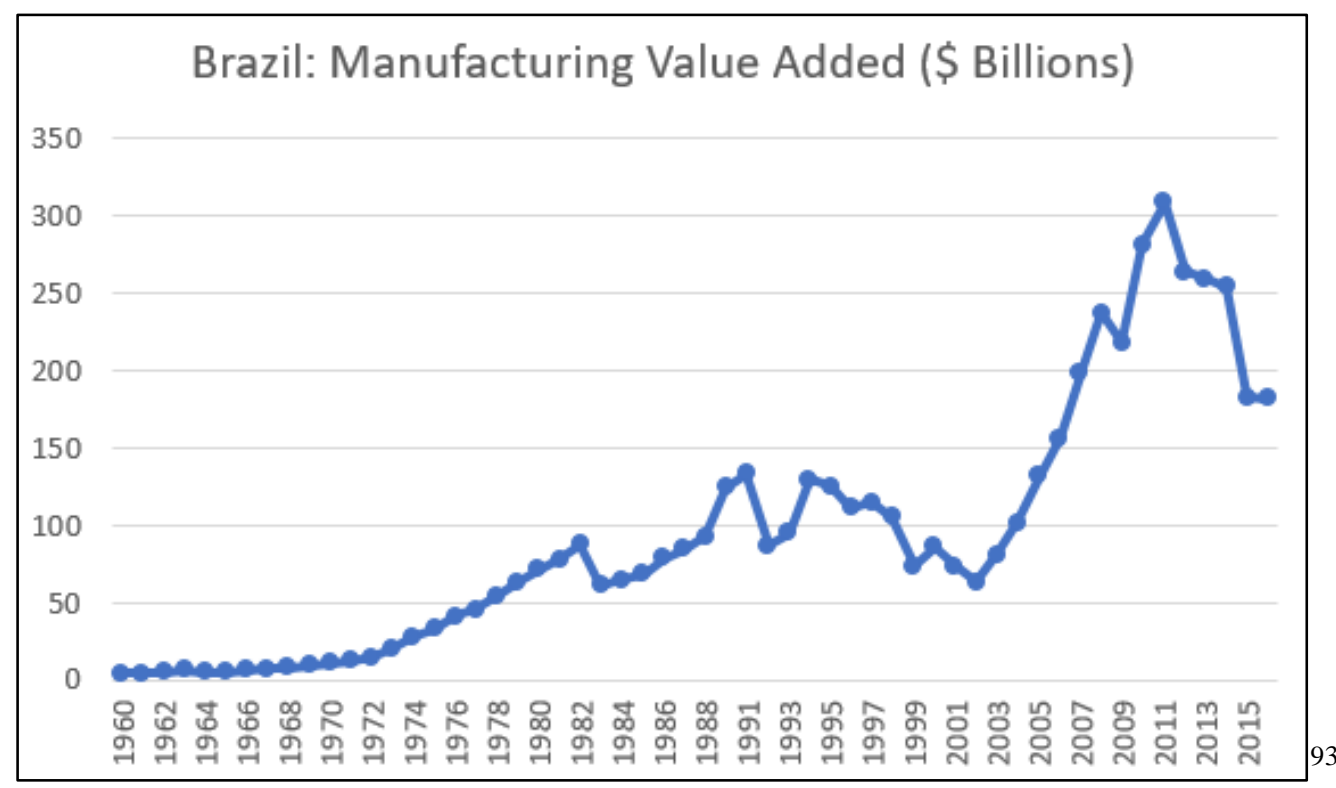

Graph 40: Brazil Manufacturing Value Added (\$ Billions)

${ }^{92}$ The Global Economy. http://www.theglobaleconomy.com/. Accessed 14 January 2018.

${ }^{93}$ The Global Economy. http://www.theglobaleconomy.com/. Accessed 14 January 2018. 
Without continued diversification away from an export-centric model, and simultaneous pursuit of regional economic integration, Brazil may remain in the situation that has historically plagued its development. Essentially, there has been a reciprocal relationship between democracy and economic integration for Brazil and other countries of the Southern Cone. Integration for political reasons helped consolidate a new democratic regime in Brazil, and because of this logic, integration receives high-level political attention throughout the region. ${ }^{94}$

The election of Cardoso was clearly a decisive break from the nationalist and statist policies of the previous sixty years, whose policies permitted the takeover of foreign capital in critical industrial sectors. The subsequent election of Lula and Rousseff completed this "great leap backwards" by decisively turning to extractive capital as the driver of the economy (Petras 2013, 472). Cardoso's election resulted in a push towards denationalization and privatization of the economy, coupled with the ascendancy of extractive capital. The present extractive economy centers on agriculture, mining, and energy. The opening of these sectors arguably comes at the expense of productive forces in manufacturing, technology, and high-end services.

Cardoso's plan to reform Brazil was a major success in pushing back the state's role in the economy. The plan ended the state monopoly of oil, gas distribution, and communication while pushing forward with privatization. However, Brazilian privatization was not as intense as that of other countries in Latin America: Petrobras was not privatized, but lost its monopoly. Also under Cardoso, Brazil put in place a social

\footnotetext{
${ }^{94}$ Mercosul (Mercosur, in Spanish), a regional trading and economic integration bloc, has made it difficult for countries in the region to implement military rule once more.
} 
safety net. Lula, although a critic of Cardoso, kept some of the latter's economic reforms in place once elected. Because Lula stated he would not alter the work of Cardoso, Brazilians felt they could safely elect the determined leftist (Reid 2014, 137). However, many Brazilians disliked Cardoso's policies, and it was Lula's social policies which drove the electorate.

The Lula Era and Beyond:

Lula (2002-2010) entered the political stage as a person who overcame great obstacles to reach power; his struggle inspired Brazilians and the world alike. Despite fears of leftist populism, Lula maintained some of the policies of the Cardoso administration, particularly those of economic stabilization to control inflation. Lula was less aggressive concerning neoliberal policies than Cardoso, and more committed to redistributive income and social improvement.

The 2002 electoral victory of Lula, contrary to what many expected or hoped, was to some extent the deepening and expansion of neoliberalism in Brazil. According to Petras (2013), this was a "great reversal" as Brazil returned to being a primary commodity exporter: soy, cattle, and iron increased, while textiles, transport, and manufacturing decreased. During this time, Brazil also became one of the leading extractive commodity exporters in the world, and the country's dependency on these exports was aided by the massive entry of MNCs (Petras 2013, 470). Brazil lost its ability to run an industrial policy and was compelled to rely on commodities.

Lula's journey began with the creation of the Worker's Party (PT) in 1980, which argued for a new socialist party based on the working class, as well as one that broke 
from elitist conciliation. The PT formed itself from union leaders, as well as three other important groups. ${ }^{95}$ The PT became Latin America's biggest, most authentic, and most successful left-wing party. By the end of the 1990s it had over 200,000 active members (Reid 2014, 141). This party also could claim to be the only one created from below as opposed to from within the state; its only challenger was the communist party, whose policies were dictated from abroad. Once in power, President Lula called for several reforms across the political, economic, and societal spectrum: pensions, tax, labor, the political system, the financial system, and land.

During Lula's tenure, he began to drift towards state capitalism, and launched the Growth Acceleration Program, placing Dilma Rousseff in charge. Two years later, there was a major oil discovery off the south-east coast, and Lula placed Rousseff in charge of this as well. At the time, Rousseff chaired the Board of Petrobras, and drew up a new legal framework for the sub-salt layer giving Petrobras a monopoly over its exploitation while maintaining existing contracts. By 2008, Brazil became a net foreign creditor with a solid credit rating, thus allowing for a deepening of capital markets in Brazil (Reid 2014, 189). During this period there were also heavy investments in Petrobras.

President Lula continued with some of Cardoso's privatizations and reconfigured Brazil's policies towards the benefit of foreign and domestic capital, which was in the primary goods export sector. Lula was unable to completely escape the neoliberal policies implemented under his predecessor. Brazil's export sector benefitted from the rise in commodity prices, akin to the experience of Bolivia and elsewhere. Free-market

\footnotetext{
${ }^{95}$ These groups comprised Catholics who favored Liberation Theology and the landless; the remnants of guerrilla movements of the 1960s and 1970s, to include Trotskyist elements; and, leftist intellectuals and students.
} 
policies in Brazil allowed in lower-priced manufactured goods from Asia, particularly China. Brazil's dependence on a limited number of commodities resulted in a decline in productive forces (Petras 2013, 473). Moreover, under the leadership of the PT, FDI continued apace into Brazil, but only because the country was performing very well, leading to increasing expectations (see Graph 41, below). By many indicators, the Lula and Rousseff regimes were quite lucrative for foreign financial capital.

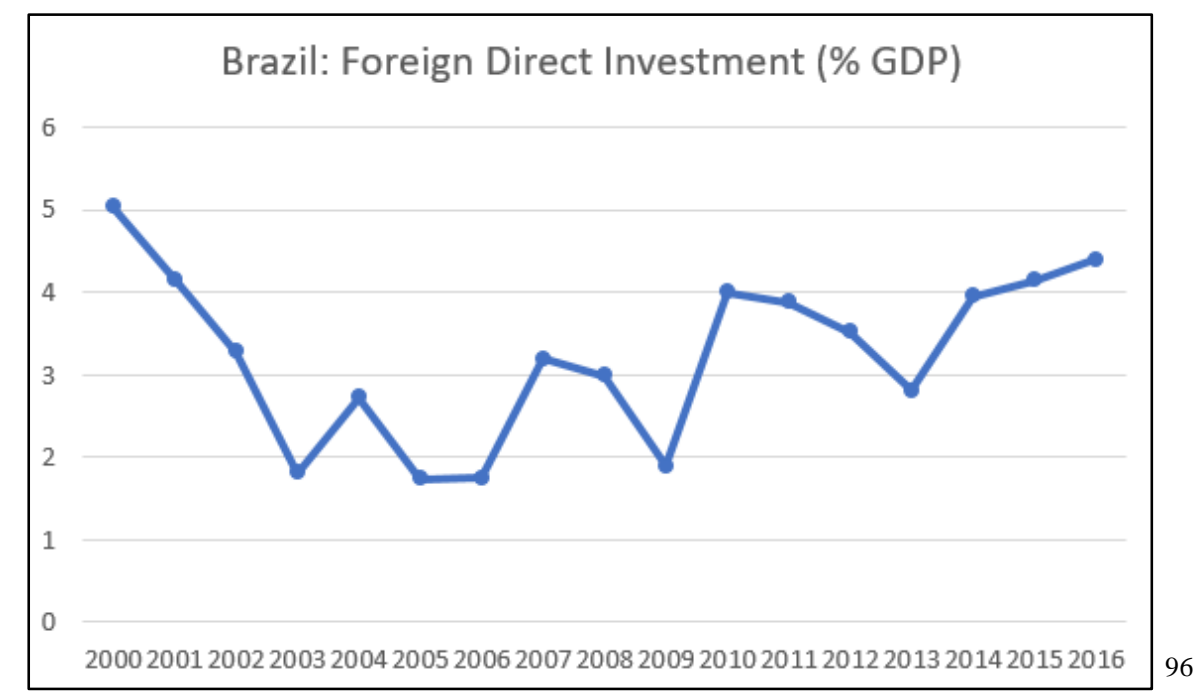

Graph 41: Brazil Foreign Direct Investment (\% GDP)

As global demand decreased, the extractive-led model in Brazil and elsewhere stagnated and declined around 2012/2013. The Cardoso, Lula, and Rousseff regimes pursued a conservative, elitist agenda buoyed by clientelist and paternalist politics that neutralized opposition for an extended period (Petras 2013, 477). Essentially, economic orthodoxy and populist demagoguery are no substitute for structural changes in the economy. In a classic example of continued rentism in Brazil, competition for mining

${ }^{96}$ The Global Economy. http://www.theglobaleconomy.com/. Accessed 14 January 2018. 
contracts, land grants, and large infrastructure projects encourages elites to buy off the party in power to secure competitive advantage. The worldwide commodity boom hid the vulnerability of Brazil's extractive economy, which remains dependent upon primary exports to limited markets.

Despite Petras' "great leap backward," he offers a weak conclusion and no serious prescription for the future (Petras 2013, 472). Petras ends his work by lamenting the Lula and Rousseff dream failed to bring about structural changes. He then shifts the argument towards the emotive by citing the plights of Brazil's indigenous people, climate change, and how capitalism will destroy the Amazon. His paper then critiques the lack of structural change under Lula and Rousseff, but fails to consider that these leaders were simply caught in the middle of internal and external forces, which are likely resistant to such change.

Relative to external economic forces, Markus Kroger (2012) argues that Neomercantilist capitalism (NMC) had an impact on Brazilian capitalism and industrial policy. ${ }^{97}$ Kroger argues statism, a return to the $1950-1970$ period of government intervention, is again being embraced and relies on the same institutions created during the earlier era. Because of external shocks, state-steering of the economy is now more legitimate than previous periods. This new statism in the emerging markets largely adopts a neo-developmentalist agenda. ${ }^{98}$

\footnotetext{
${ }^{97}$ Neo-mercantilist Capitalism (NMC) is defined as a strategy aimed to create export-focused, leading global-sector corporations via mergers orchestrated by key-politicians, capitalist, and state financial institutions (Kroger 2012, 888).

${ }^{98} \mathrm{Neo}$-developmentalism is used by neo-mercantilists as it integrates a national system of control and export-led accumulation of capital (Kroger 2012, 889).
} 
Upon reelection in 2014, the fourth consecutive PT win, Rousseff was beset with domestic challenges, the most salient being a probe into a kickback scheme at Petrobras. Despite reelection, Rousseff's mandate was weak; her narrow defeat (51.6\%) over her challenger, Aécio Neves of the PSDB (48.4\%) did not strengthen her hand. The PSDB never accepted Rousseff's win, and arguably began to sabotage the government, creating unrest that only added to the burgeoning economic crisis. Up until her impeachment in 2016, Dilma Rousseff maintained Lula's approach and included regional integration, a central component of Chapter Four in this dissertation. During Rousseff's presidency, social unrest and a weakening economy worsened amid a major scandal involving Petrobras. A weakened Petrobras had trickle-down effects across the country as the parastatal is estimated to affect roughly $20 \%$ of Brazil's national economy through its subsidiaries, suppliers, and contractors (Mares and Trinkunas 2016, 78). During Rousseff's second term, a lack of confidence in markets, a recession, and credit downgrade resulted in stalled or reversed social programs, nourished the overall negative atmosphere that accompanied numerous corruption scandals, ultimately encouraging mass protests. Essentially, Brazil's commodity-fueled growth at a time of high demand led to unrealistic expectations for a sustainable and rising economy.

The constraints at the end of Rousseff's presidency (impeached and replaced by Michel Temer in 2016) pushed her administration toward a more liberal economic policy, as well as improving relations with major powers (Mares and Trinkunas 2016, 83). Historical experience suggests that Brazil will lean towards a centrist leader who will push ahead with Temer's reforms. However, this assessment risks miscalculation. 


\section{Brazil's Natural Gas Relationship with Bolivia: A Synopsis}

To support its industrialization, Brazil needed to look to hydrocarbons, whereas previously Brazil mostly relied on firewood and charcoal for its energy needs. As aforementioned, Petrobras was created in 1953 and granted a near-monopoly of exploration, production, refining, and the transportation of oil. Global events brought about a policy shift in the 1970s and compelled Brazil to reduce its dependence on imported energy. Such thinking was the foundation for the pipeline agreement between the NOCs of Brazil and Bolivia in 1992 (GASBOL pipeline).

The pipeline plan was to transport Bolivian natural gas to the Brazilian southeast. Between Bolivia and Brazil, GASBOL initially provided a 16 million m3/day (cubic meters per day) capacity, and subsequently increased this to 30 million m3/day (Prates 2006, 10). With the construction of GASBOL, Bolivia became the largest external natural gas provider to Brazil.

Presently, natural gas accounts for roughly $11 \%$ of primary energy consumption in Brazil, and its domestic production is insufficient to meet demand (BP Statistical Review 2017). Despite much of Brazil's energy deriving from hydroelectric power, during droughts this solution becomes a costlier alternative than other available forms of energy such as hydrocarbons. ${ }^{99}$ Because of strategic planning and investment in exploration, Brazil's gas reserves increased 25\% between 2009-2014. Along with Colombia, Peru, and Venezuela, Brazil is one of the only countries to witness growth in gas reserves during this period. This situation is unlike Argentina and Bolivia, which

\footnotetext{
${ }^{99}$ As renewable energy forms become cheaper these types of calculations will remain fluid.
} 
suffer from a lack of research and exploration investments; Bolivia experienced a halving of reserves during the same period (Gomes 2014, 14).

The discovery of pre-salt deposits off the southern coast of Brazil has increased proven reserves; market experts anticipate the amount of reserves will increase as exploration continues. Regardless of additional discoveries, Brazil, as the largest regional economy, will remain a key player in any Latin American energy integration scenario. However, the devil is in the details as questions remain regarding cooperation prospects in the region.

\section{Works Cited}

Bethell, Leslie. "Populism, Neopopulism, and the Left in Brazil; from Getulio to Lula." Latin American Populism in the $21^{\text {st }}$ Century, edited by Carlos de la Torre and Cynthia J. Arnson, Woodrow Wilson Center Press, 2013.

Burns, Bradford E. "Nationalism in Brazil: A Historical Survey." Frederick A Praeger Publishers. New York. 1968.

De La Torre, Carlos and Cynthia J. Arnson, "Introduction." Latin American Populism in the $21^{s t}$ Century, edited by Carlos de la Torre and Cynthia J. Arnson, Woodrow Wilson Center Press, 2013.

Demmers, Jolle et al. "Preface." Miraculous Metamorphoses: The Neoliberalization of Latin American Populism, edited by Jolle Demmers, Alex E. Fernandez, and Barbara Hogenboom. Zed Books. 2000.

Faoro, Raymundo. "Os Donos do Poder: Formação do Patronato Político Brasileiro." Editôra Globo. Rio de Janeiro. 1958.

Fausto, Boris and Sergio Fausto. "A Concise History of Brazil (2nd Ed.)." Cambridge University Press. New York. 2014.

Gomes, Ieda. "Brazil: Country of the Future, or has its Time Come for Natural Gas?" Oxford Institute for Energy Studies, no. NG88, Jun. 2014, pp. 1-74.

Johnson, Harry G. "A Theoretical Model of Economic Nationalism in New and Developing States." Economic Nationalism in Old and New States, edited by Harry G. Johnson, University of Chicago Press, 1967, pp. 1-16.

Kingstone, Peter R. and Timothy J. Power. "Democratic Brazil: Actors, Institutions, and Processes," edited by Peter R. Kingstone and Timothy J. Power, 2000. 
Kroger, Markus. "Neo-Mercantilist Capitalism and post-2008 Cleavages in Economic Decision-making Power in Brazil." Third World Quarterly, vol. 33, no. 5, 2012, pp. 887901.

Mainwaring, Scott. "Democracy in Brazil and the Southern Cone: Achievements and Problems." Journal of Interamerican Studies and World Affairs, vol. 37, no. 1, Spring 1995, pp. 113-179.

Mares, David and Harold Trinkunas. “Aspirational Power.” Brookings Institution Press. Washington. 2016.

Meade, Teresa. “A Brief History of Brazil.” Checkmark Books. New York. 2010.

Petras, James. "Brazil: Extractive Capitalism and the Great Leap Backward." World Review of Political Economy, vol. 4, no. 4, Winter 2013, pp. 469-483.

Prates, Claudia Pimentel T, et al. "Evolução da Oferta e da Demanda de Gás Natural no Brazil." O Banco Nacional do Desenvolvimento, no. 24, 2006, pp. 35-68.

Reid, Michael. "Brazil: The Troubled Rise of a Global Power." Yale University Press. New Haven. 2014.

Skidmore, Thomas E. "Politics in Brazil 1930-1964: an Experiment in Democracy." Oxford University Press. London. 1967.

Smith, Peter Seaborn. Petroleum in Brazil: A Study in Economic Nationalism.

Dissertation, University of New Mexico, 1969.

Weffort, Francisco C. "State and Mass in Brazil." U.N. Economic Commission for Latin America (CEPAL). 1966.

Wiarda, Howard. "The Soul of Latin America: The Cultural and Political Tradition." Yale University Press. London. 2001.

Wirth, John D. “The Politics of Brazilian Development 1930-1954.” Stanford University Press. Stanford. 1970.

Victor, David, et al. "Oil and Governance: State-Owned Enterprises and the World Energy Supply.” Cambridge University Press. New York. 2012.

\section{Data Sources:}

British Petroleum. British Petroleum Statistical Review of World Energy. http://www.bp.com/statisticalreview. June 2017.

The Global Economy. http://www.theglobaleconomy.com/. Provides updated economic statistics from official sources (i.e. World Bank, International Monetary Fund, and the United Nations).

MIT. The Observatory of Economic Complexity. http://atlas.media.mit.edu/en/. 


\section{CHAPTER FOUR}

\section{Introduction}

This dissertation defines and compares two concepts: resource nationalism and energy integration. The study then tests to determine if there is a relationship between the concepts. Key to this dissertation is understanding and explaining why populists or economic nationalists pursue market integration. Resource nationalism (Independent Variable) is the notion that control over a nation's economy should be in the hands of nationals, that nationals should have preference over foreigners in reaping the benefits of business and economic opportunities in the country, and nationalist resentment of foreign investment. Energy integration (Dependent Variable) is reflected in exports of natural gas from Bolivia to Brazil, whereby an increase of natural gas imports into Brazil is the central indicator (Gonzalez et al 2008).

Chapters Two and Three identified the political leaders who are considered resource nationalists in Bolivia and Brazil. Macroeconomic data presented thus far demonstrates there is not a clear delineation when resource nationalists cum populists did what was expected relative to ISI, open markets, and energy trade relationships. Resource nationalists in each country during the periods under study have always been under both internal and external pressure to do what was needed and required, which was not always what was desired or initially promised.

Nowhere were these inherently difficult decisions more salient than when concerning the hydrocarbons sector in both countries, whether in an import or export capacity. The natural gas pipeline relationship between Bolivia and Brazil is key in 
answering two questions. ${ }^{100}$ First, what is the relationship between resource nationalists and open markets in the hydrocarbons sector, particularly natural gas? Second, what is the relationship between populists, who are typically resource nationalists, and their decision to choose policies of energy integration? To compare concepts, macroeconomic and natural gas data (indicators for integration) are compared against the previously defined periods of resource nationalism in both Bolivia and Brazil.

Data, Sources, and General Statement:

This chapter offers a better understanding of the benefits of Bolivian natural gas integration with Brazil as the relationship between resource nationalism and market integration is better understood. Data descriptions may be found in Chapter One. Interviews and discussions with key informants took place between September and November 2017.

This chapter is broken into several sections. Earlier in the dissertation, energy conversions and a timeline provide fundamental understanding and context. Such context additionally explains why natural gas is increasingly important to consider in the global energy portfolio. Second is a discussion of national oil companies (NOCs), to include historical presence and influence in both Bolivia and Brazil. Next, separate sections on

\footnotetext{
${ }^{100} \mathrm{GASBOL}$ is a $3150 \mathrm{~km}(\sim 1957 \mathrm{mi})$ pipeline, which includes a $557 \mathrm{~km}(\sim 346 \mathrm{mi})$ portion from Santa Cruz de la Sierra in Bolivia to the Bolivian border near Corumbá, Brazil. On the Brazilian side, the pipeline continues to São Paulo, then on to Porto Alegre. GASBOL is the single largest private sector investment in Latin America, when at the time of GASBOL's envisioning, there was a growing understanding that private participation in the energy sector could reap economic benefits as well as lessen government risk.
} 
natural gas and energy use in Bolivia and Brazil provide additional scaffolding for the subsequent section on their integration. Last, this chapter presents a summary of major findings.

Energy is and will remain vital to all modern economies. The dual revolutions of horizontal drilling and hydraulic fracturing have fundamentally changed the worldwide hydrocarbon landscape. The clearly demonstrated U.S. ability to extract hydrocarbons from under the Earth's surface has resulted in other countries' desires to take a similar approach. This dual revolution will soon alter the relative strengths and weaknesses of the most important nations in the world. Particularly concerning pipelines and the oftuncomfortable geopolitical marriages between energy rich and energy poor countries, many countries and economies in the world were hitherto held hostage to their energy demand. Resource rich countries have historically been more fortunate than the resource poor. That there are now additional options, countries without hydrocarbon resources are presently at least able to consider a variety of suppliers to include political allies.

Unlike oil, there is no unified world market for natural gas, but a segmented one whereby prices are established taking several factors into consideration, particularly local and regional markets (Garron et al 2007, 4; Medinacelli 2018). The Southern Cone, comprised of Argentina, Bolivia, Brazil, Chile, Uruguay, and Paraguay represents the largest market for natural gas in South America and reflects interconnections as well as transactions between countries. The sheer volume of gas transactions between Bolivia and Brazil represents an important percentage of this market (Garron et al 2007, 7). The weightiness of this market drives the focus of this case study. 


\section{Why Natural Gas is Important}

Natural gas, like other forms of anthropogenic energy, is one of many arrangements whereby humans use the Earth's resources to improve their chance of survival and enhance their quality of life. ${ }^{101}$ Throughout history, energy prime movers evolved from human and animal labor, to the pre-industrial use of biomass fuels. Beyond biomass, humans adopted new energy forms during the last two centuries, which have predominantly been hydrocarbons. Nearly five millennia of preindustrial history were mostly dominated by the inefficient burning of biomass fuels as a source of heat for households, metallurgy, and artisanal manufacturing. A major transition took place only in the last few centuries, demonstrated by the move from biomass to fossil fuel. This transition began in small scales, and the earliest innovators maintained their advantage for a time (Smil 2010, 25).

Natural gas was known to antiquity. In the modern era, and in the absence of long-distance pipelines, gas was used for local lighting, but was mostly flared (wasted) when drilling for oil. Large-diameter and high-pressure pipelines carried gas over long distances. After the Second World War, metallurgical advances allowed for a pipeline construction boom where gas became an important global industry (Smil 2010, 37).

Today natural gas is more efficiently captured, although much continues to be wasted. According to interview subject 25800-201, natural gas continues to be grossly wasted where the substance is often flared for a week at a time despite its economic use as a fuel. Often, field operators are inefficient, wasteful, and reactive to events rather than considering economic efficiency. Despite sunk costs, many field operators will shut

\footnotetext{
${ }^{101}$ Anthropogenic: caused or produced by humans.
} 
down drilling operations based on a $\$ 1$ to $\$ 2$ dip in the price of oil, only to restart drilling a week later when there is a rebound. Shutting down a drill requires about four days (24 hours/day operation) and costs hundreds of thousands of dollars. "Nobody wastes money like the petrochemical industry. You think government is wasteful until you see the amount of money wasted first hand in the petrochemical sector."102

Natural gas moved from less than ten percent to over a quarter of the world's energy usage in the last seventy years. This is an impressive amount if juxtaposed against total world energy use. The clean combustion of natural gas makes it an attractive choice when compared to coal and oil. However, despite the cleaner nature of natural gas and the desirable and eventually inevitable transition towards a non-fossil fuel future, it is exceedingly difficult to restructure our modern and high-energy civilization based on non-fossil fuels (i.e. renewables).

A central paradox for natural gas is its great value for human use alongside its low economic value per unit, especially when compared to oil (Smil 2015, 11, 68).

According to interview subject 25800-201, whereas oil is used across the spectrum from energy to manufacturing and goods (i.e. lubricants; plastics; paints), natural gas is good for energy use and production alone. Natural gas is cleaner, and it will be possible to run drilling operations with natural gas once systems become more efficient. However, oil will not simply give up its economic space to natural gas with the justification of being a cleaner fuel source. ${ }^{103}$ Additionally, there has never been a worldwide transportation network for natural gas in its gaseous state, as compared to that of oil, which is fungible

\footnotetext{
${ }^{102}$ Interview which took place between SEP and NOV 2017.

${ }^{103}$ Interview which took place between SEP and NOV 2017.
} 
across geographies. Gas is uneconomical to transport except via pipeline, which results in a highly-localized market and widely varying price. Advances in energy trading may change this dynamic as the world is undergoing a major shift from oil to natural gas resulting from the shale revolution and LNG, possibly making natural gas a worldwide market.

Hydrocarbons presently comprise roughly $80 \%$ of world energy demand. Despite implementation of projected climate change agreements, this percentage will potentially decrease to $75 \%$ amid a world energy usage increase of $35 \%$ based on 2040 projections (IEA 2017). According to interview data from subject 25800-201, populist governments, like all governments, need to sell oil and natural gas regardless of their political ideology if they are to maintain a positive balance of payments, as well as to generate income to develop or improve the country; though, elites remain the big winners. Commodities are useless if they remain in the ground, and in many countries in Latin America, natural resources are pretty much all they have. Concerning natural gas, the potential to capitalize on the LNG market is possible if liquefication plants are developed in time to meet market need. "LNG is a major issue and a potential game-changer at a global level, if it takes off." Specific to Bolivia, unless it develops its own markets away from being a simple supplier of commodities in the larger world market, it will not be able to develop as fully or as well as other countries in the region like Argentina, Brazil, or Chile. In the case of Bolivian markets in general, this may also possibly include lithium as a commodity. ${ }^{104}$

\footnotetext{
${ }^{104}$ Interview which took place between SEP and NOV 2017.
} 
Additionally, interview subjects 25800-201, 25800-203, 25800-204, 25800-205, 25800-206, 25800-207, and 25800-209 maintain the region is mostly a consumer of finished products, and provider of commodities and services. Of course, larger or more advanced economies are better able to develop markets than poorer ones. Brazil is one economy large enough to have consumers of finished products both domestically and internationally, whereas Bolivia is mostly a producer of natural resources such as agriculture and natural gas. ${ }^{105}$ Interview subject $25800-209$ adds that in addition to much economic activity in South America providing agriculture and commodities for export, there is still great economic differentiation in the region whereby countries such as Argentina, Brazil, and Chile look outside of the region for markets and investment while “...fragile democracies in the region suffer from weak institutions, poor governance, and transnational criminal threats that undermine political stability, which in turn frightens away needed FDI." 106

Returning to a global perspective, in addition to a potential wider array of energy import options, there is now the increased opportunity to choose to not exploit the resources of one's own country, but instead buy from exporters that may provide necessary resources at a lower price. Separately, reduced costs may bring once-lost manufacturing jobs back to countries where opportunities were cost prohibitive only a few years ago (Dumaine 2015). The ramifications for such a sea change in economic arbitrage are not yet wholly understood or appreciated. Cheaper energy via a wholesale reduction in costs across the manufacturing supply chain clearly exist (Arezki 2016).

\footnotetext{
${ }^{105}$ Interview which took place between SEP and NOV 2017.

${ }^{106}$ Interview which took place between SEP and NOV 2017.
} 
Beyond the importance of natural gas as a fuel, no serious discussion of this resource may take place without at least a brief mention of contracts between producing and consuming nations, or the involvement of IOCs and NOCs in their facilitation. The two central actors in the development of any resource are the country which holds the resource and the extracting IOC or NOC. The central difference between gas and oil projects is the long-term nature of the former, as gas projects must be seen in their totality (i.e. planning, market development, financing, production, delivery, distribution, and consumption). The fungible nature of oil transactions does not require the same considerations as does natural gas. Historical distrust between governments and IOCs further complicates natural gas relationships. According to interview subjects 25800201, 25800-203, 25800-207, and 25800-209, trade, particularly that of energy, can benefit all; however, in South America, historical grievances often inhibit sensible economic agreements. ${ }^{107}$ Despite challenges, the development of legal, contractual, and fiscal frameworks is a step towards resolving such distrust in South America. According to interview subject 25800-209, trade frameworks in Latin America are also challenged. Unlike the European Union (E.U.), Latin America differs first because of it being less industrialized, but also that the E.U. was better able to efficiently craft or develop guidelines and regulations because of a deeper and shared history. These regulations facilitated integration in the E.U., while in Latin America, regional diversity impedes integration despite natural gas being its best option, at least in the Southern Cone. ${ }^{108}$

\footnotetext{
${ }^{107}$ Interview which took place between SEP and NOV 2017.

${ }^{108}$ Interview which took place between SEP and NOV 2017.
} 
Take-or-Pay contracts help safeguard the interests of both upstream and downstream parties in the natural gas industry. ${ }^{109}$ The Bolivia-Brazil case demonstrates how positions change during the three phases of the ToP lifecycle. Contract enforcement requires central mechanisms such as stakeholder self-enforcement, and recourse to a third party which guarantees dispute settlements. The ToP contract allows for the maintenance of good relations between the parties, and its ability to adapt to change. ToP is a risksharing agreement and insurance mechanism for upstream production and downstream consumption (Glachant and Hallack 2009, 651).

Despite contractual agreements, the associated factors of regulation and legal complexities in negotiating cooperative agreements stand to confound the lofty aim of integration. In the case of Bolivia, concern exists in the wake of the 2005 Hydrocarbon Law, whereby the increased cost of IOC operation and investment in the natural gas sector may inhibit IOC investment in exploration and development of natural gas deposits. As the Bolivian government is becoming increasingly aware of the looming need for such investment, nowhere are clear contracts and arrangements more important.

\section{Background on NOCs, Petroleum, and their Relationships in Brazil and Bolivia}

The petroleum industry dominates the economies of many developing countries and has consequences for democratization, development, institutional performance, and the world economy at large. The bulk of Bolivia's revenue derives from natural gas sales

\footnotetext{
109 Take or Pay (ToP) is defined as a firm commitment to purchase a minimum quantity of gas downstream. Ship-or-Pay (SoP) is a firm commitment to provide a minimum quantity downstream. For a detailed description of ToP contracts in the Bolivia-Brazil case, see Medinacelli (2017).
} 
to Brazil, and we must understand how Brazil came to be such an important customer and the weight its parastatal, Petrobras, brings to the relationship.

In the region, relationships among countries are often tenuous, and integration is challenging, particularly in the energy sector. According to interview subjects 25800 201, 25800-203, 25800-204, 25800-205, 25800-206, and 25800-207, relationships between and among countries in South America are frequently uncomfortable. Such discomfort undermines economic and energy integration. Often, countries in the region take foreign development and technical knowledge, then nationalize the alreadydeveloped sector to their benefit. This further weakens trust between governments, respective NOCs, and related IOCs. ${ }^{110}$

Specific to Brazil's NOC, the history of Petrobras divides into three main periods: early (1954-1973); middle (1974-1994); and 1995-present. ${ }^{111}$ Important is the post-1995 period through the present, which was a period of deregulation in Brazil. In 1995, the monopoly Petrobras enjoyed was removed under president Cardoso, who aimed to improve the economic ills then plaguing Brazil with the implementation of liberal market reforms. The privatization of Petrobras (not complete, but it lost domestic monopoly power), along with the liberalization of the oil market, were part of a larger package intended to improve economic efficiency and associated performance (Victor et al 2012, 538). Brazil was late in ending the Petrobras monopoly, and what is presently happening

${ }^{110}$ Interviews which took place between SEP and NOV 2017.

111 The early period was when Petrobras used its state monopoly to organize its downstream. The middle period was one of "learning by doing" as Petrobras developed offshore deposits, first mastering the shallows, then increasingly moving to deeper waters. During these two periods, Petrobras used its position to lower risks amid attempting to insulate itself from hyperinflation and economic instability (Victor et al 2011, 516). 
is of interest to the parastatal. Historically, Petrobras bought imported gas and occasionally lost money because it assumed all the risk. Now, Petrobras does not want to assume these same risks. As there are other actors in the market, the ability of Petrobras to absorb such risk is unsustainable (Almeida May 2017).

With the support of Brazil's National Bank for Economic and Social Development (BNDES), Brazilian companies are likely to play a major role in positioning Brazil as a partner in development. However, despite the stated desire of countries in Latin America to promote energy integration, there is no agreed-upon approach to achieving this goal. Brazil is often trapped in costly or pointless efforts which undermine integration. One example of such an effort was the failed 2005 BrazilArgentina pipeline through the Amazon. In this instance, Petrobras was reluctant, but Lula invested in this project to promote positive political relations. A similar mentality forced Petrobras to involve Venezuela's PDVSA to construct a refinery in Pernambuco. Venezuela was ultimately unable to collaborate, and Petrobras constructed the project alone (Mares and Trinkunas 2016, 118).

Another example of how integration enthusiasm is undermined was palpable in 2006 between Bolivia and Brazil, as the former nationalized its upstream gas sector. That this nationalization took place and simultaneously detracted from regional integration clearly speaks to the heart of this dissertation as natural gas is indicative of integration between Bolivia and Brazil. The natural gas industry in Brazil is a relatively new market, having been increasingly developed since the late-1990s, when the country's oil activity was opened to private initiatives. Natural gas consumption in Brazil has also seen steady growth since the operation of the Bolivia-Brazil pipeline. 
Unsuccessful integration efforts are not limited to Brazil, however. According to interview subject 25800-202, in the late-1990s, Bolivia created an LNG consortium (Pacific LNG), which aimed to move LNG to the U.S. state of California. There was major investment in this project, and the Bolivian government chose to construct a pipeline through Chile for economic reasons. Bolivian historical animosity towards Chile was intense, and the resulting protests against transporting Bolivian LNG through Chile deterred the government from pursuing this option. An alternative through Peru was floated, but the additional cost made the project unviable. This was an interesting development as polling data suggested $80 \%$ of Bolivians agreed the Chilean deal and its associated economic benefits would aid Bolivia. ${ }^{112}$

Bolivian resistance to natural gas sales to Chile touches on the long history of government intervention in markets. According to interview subject 25800-206, it is foolish for Bolivia to not sell natural gas to Chile, but nationalist sentiment in Bolivia is strong and the context for this perspective is understood. Despite nationalist emotion, the natural gas market between Bolivia and Chile already exists, just not officially or legally. Argentina takes advantage of the situation by purchasing Bolivian gas (from Tarija, Bolivia), and then directly selling the gas to Chile for a marked-up price. "They just wave the trucks of gas through Argentina and on into Chile. It is an open secret in the region." ${ }^{113}$ The natural gas market transcends government policy, but the political decision to not sell natural gas to Chile also denies Bolivia an additional source of revenue.

\footnotetext{
${ }^{112}$ Interview which took place between SEP and NOV 2017.

${ }^{113}$ Interview which took place between SEP and NOV 2017.
} 
According to interview subject 25800-208, government should play less of a role in the gas sector as energy nationalism is the greatest barrier to integration between Bolivia and Brazil. Geopolitical realities, not markets, drive energy integration and energy projects almost always have a geopolitical rationale. Political agreements need to exist on integration before integration negotiations can begin, and despite political differences between countries, one can always find potential for bilateral agreements, but not integration per se. Integration agreements exist across the region, but not in energy. ${ }^{114}$ Essentially, market-based energy agreements are preferable as they will function independently of political arrangements. Concerning the Bolivia-Brazil natural gas relationship, it is important to look beyond sympathetic political policies. The greatest cost to integrate the Bolivia and Brazil markets took place twenty years ago, and without political involvement would not have been a viable project because the risk was great and required the two countries cooperate politically (Fagundes de Almeira May/Jun. 2017). With market-driven agreements, government policies may change, which is normal in a democracy; however, markets endure.

According to interview subject 25800-204, countries benefit from energy trade, whether in raw materials or electricity. The benefits to each partner depend on market moves, which are often outside of the control of political leaders, and subject to domestic politics.

"It is better to have cheaper and more accessible energy than more expensive and less accessible, but costly electricity and resources bring up issues of rent-seeking, while cheaper electricity allows poorer elements of society to participate in the economy which ultimately aids GDP. The flip side of this is in Brazil where the poor in the favelas steal or pirate electricity, while middle-classes that are

\footnotetext{
${ }^{114}$ Interview which took place between SEP and NOV 2017.
} 
adjacent to the poor areas continue to pay for the service. In the favelas, the criminal element controls much of the activity, to include providing electricity, and there is a need to bring these criminal elements, who are local power brokers, into the system, but this will require very skilled political action... There is the need to formalize these power brokers into the Brazilian system somehow."115

Returning to macroeconomic relationships, many decision-makers do not understand that prices in monopolies are established through a process in which an authority calculates price based on a cost structure inclusive of pre-established rents. This balance is upset when the boom in a commodity cycle becomes a bust. According to interview subject 25800-203, the commodity boom/bust cycle in South America resulted in historical regional volatility, and argues that populism and associated movements are a result of this same cycle as more integration into the larger, global economy results in additional volatility and upheaval. Within the extractivist model in South America, Bolivia suffers the most and is the worst example of regional extractivist abuse. Brazil is more economically advanced, and has a better ability to develop internal markets. In the case of commodities, Brazil weaned its country from oil dependence using price, and is now an exporter of oil. ${ }^{116}$

Specifically concerning Bolivia and Brazil, these countries are expected to negotiate new contracts by 2019, and a central question is if Henry Hub, benchmark price for natural gas in North America, will be the reference used in Brazil and Bolivia. However, because of hydroelectric power generation in Brazil, natural gas plays a small role in its energy matrix at under $12 \%$ of the domestic energy supply, and just over seven

\footnotetext{
${ }^{115}$ Interview which took place between SEP and NOV 2017.

${ }^{116}$ Interview which took place between SEP and NOV 2017.
} 
percent of final energy consumption. Nevertheless, natural gas consumption has steadily grown since the 1999 creation of the Bolivia-Brazil pipeline. The compound average growth rate was $10.8 \%$ from 2000-2013, but with the bulk of demand deriving from Brazil's industrial sector. Despite limited public demand for gas, however, the pipeline was a definite game-changer for both countries (Gomes 2014, 42). Complicating this relationship was the 2006 nationalization of Bolivia's parastatal, Yacimientos Petroliferos Fiscales Bolivianos (YPFB) under Bolivian President Evo Morales, which converted it into the sole export aggregator of natural gas in Bolivia, ultimately denying Brazilian gas buyers the ability to engage in contracts directly with private producers (Gomes 2014, $35)$.

With the increase in natural gas coming into Brazil from Bolivia since the creation of the pipeline, it will be later demonstrated that 2006 was an important year in the Bolivia-Brazil relationship. This importance derives from the nationalizations taking place under Bolivian President Evo Morales, a staunch resource nationalist. The effects of nationalization are also reflected in the price of Bolivian natural gas imports into Brazil. Despite the 2006 nationalizations, there remains a solid case for why Brazil and Bolivia are in an excellent position to maintain their natural gas relationship.

At the retail level, the electricity sector appears to be the most promising for the expansion of cross-border economic ties. Because Brazil dwarfs its neighbors in the size of its power sector, any integrated network would largely be driven by the dynamics of the Brazilian system. In this context, natural gas in the Southern Cone is the best opportunity for regional market integration. Although this dissertation focuses on macroeconomic relations between Bolivia and Brazil, the separate theme concerning the 
export of electricity as a finished product is something that cannot be ignored, and is briefly touched upon later in this chapter.

It is important to keep this dissertation in its proper global context regarding levels of natural gas production, consumption, and proven natural gas reserves. In the case of natural gas production (which excludes flared or recycled gas), Bolivia produced 19.7 Bcm to Brazil's $23.5 \mathrm{Bcm}$ in $2016 .{ }^{117}$ Regarding trade, natural gas movement from Bolivia to Brazil by pipeline was $10.4 \mathrm{Bcm}$ in 2017 . Consumption is another matter and varies across the region, per each country's individual energy matrix (see Graph 42, below).

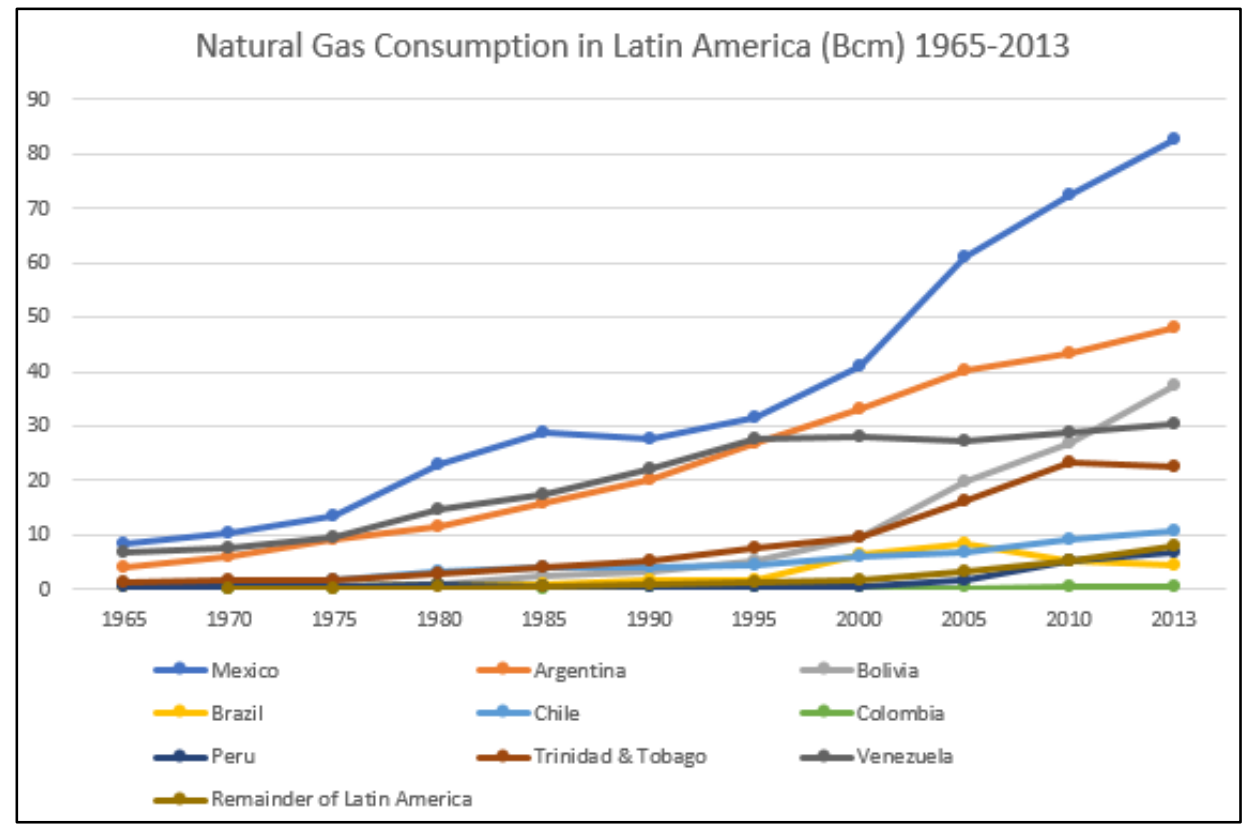

(Condor 2014, 25)

Graph 42: Natural Gas Consumption in Latin America (Bcm) 1965-2013

${ }^{117}$ BP Statistical Review of World Energy 2017. 
Concerning natural gas endowments, Bolivia and Brazil each comprise $0.2 \%$ of the world's proven reserves. Regionally, this number pales in comparison to Venezuela, which holds $3.1 \%$ of the world's proven natural gas reserves. The remainder of proven natural gas reserves break down as follows: Middle-east (42.5\%), Europe and Eurasia (30.4\%), Asia Pacific (9.4\%), Africa (7.6\%), North America (6\%), and all Central and South America (4.1\%). These numbers exclude crude oil, and do not preclude additional discoveries. ${ }^{118}$

\section{Bolivia}

Bolivia has favorable natural gas prospects, and its strategic location in South America as an exporter amid numerous importers bodes well for its future performance as a natural gas producer. However, a potential shift in focus from exports to domestic natural gas consumption, which is necessary (and legally mandated) to satisfy local and industrial needs first, could tighten supply in the years ahead. Last, as the worldwide shale revolution progresses, Bolivia may find additional hydrocarbon resources in its Chaco Basin (Reuters Nov. 2016).

${ }^{118}$ BP Statistical Review of World Energy 2017. 


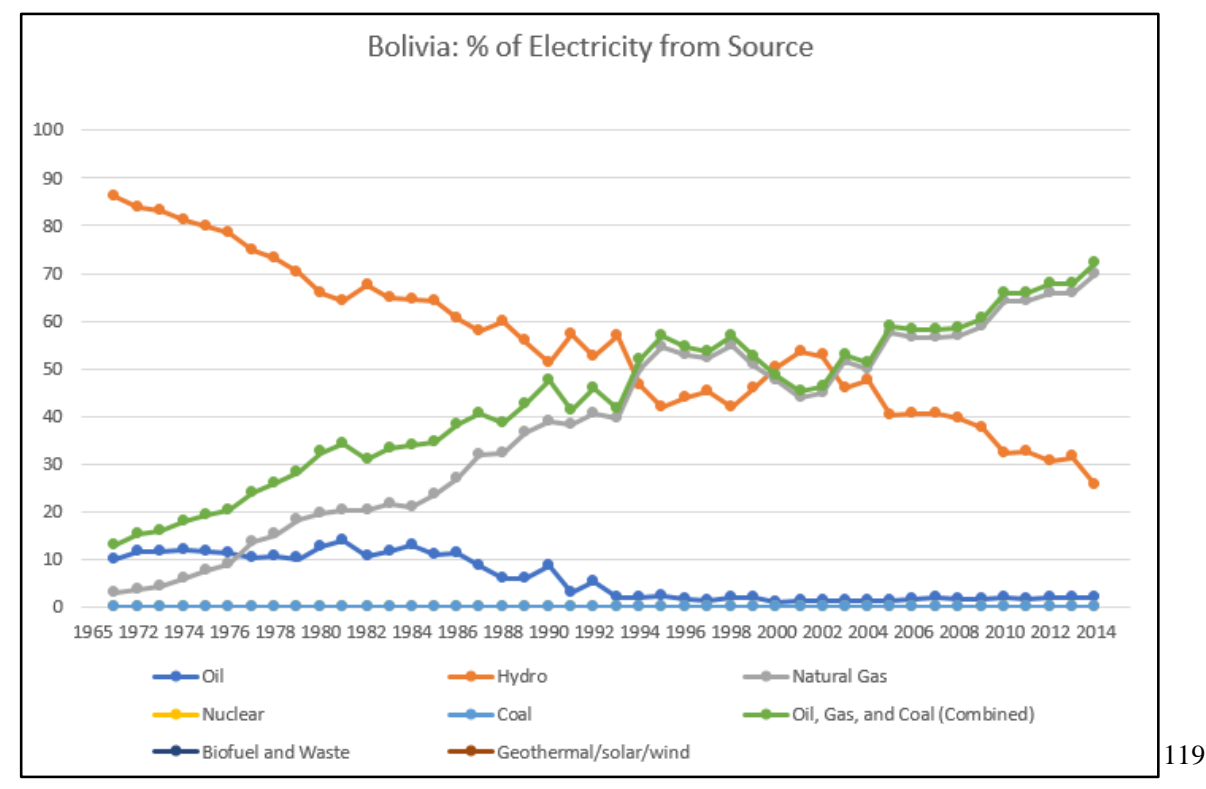

Graph 43: Bolivia Percentage Electricity from Source

Referencing Graph 43 (above), Bolivia currently produces most of its electricity from natural gas, which is inversely correlated to its use of hydro power. The use of coal and oil is absent, and that of solar or wind never passed two percent (excluded from graph). Natural gas became increasingly important after the early 1970s, and replaced both coal and oil as the hydrocarbon of choice for electricity production in the early 1990s.

Natural gas trade discussions in South America date to the 1950s/60s, and integration attempts began in 1970s with the Bolivia-Argentina pipeline (Yabog). Argentina's discovery of gas subsequently expanded its market to Chile (1996-2001), with aspirations to enter the Brazilian market and compete with Bolivian gas, which it did in 2000 (Honore 2016, 6). According to interview subject 25800-202, the natural gas agreement between Bolivia and Argentina was an IOC concept of integration, not

\footnotetext{
119 The World Bank.
} 
developed indigenously. Nevertheless, because of its success, Bolivia and Brazil later looked toward their own energy integration with the initial agreement focusing more on state needs than those of any IOC. ${ }^{120}$

Additionally, interview subject 25800-202, explains the history of natural gas in Bolivia dates to the 1960s, when exploration in Santa Cruz resulted in substantial discoveries. Because the demand in Bolivia was weak, the decision to export gas to Argentina was made via U.S. firm Gulf Oil Company despite many Bolivians describing the arrangement as unfair. Presently, although Bolivia desires hydropower, such a project requires freshwater, a scarce resource in the country. ${ }^{121}$ Electricity produced from nuclear, biofuel, and waste are either absent or nominally used in Bolivia.

Of note regarding the development of natural gas as a potential Bolivian export, according to interview subject 25800-208, the development of the natural gas market in Bolivia was strongly influenced by the U.S as at that time Bolivia had two strong markets: coca (the base of cocaine production) and natural gas. U.S. influence in the development of the Bolivian gas market was driven by the U.S. desire to curtail cocaine production in Bolivia, and possibly the subsequent result of Bolivia becoming a failed or narco-state. ${ }^{122}$

Graphs 44 and 45 (below) demonstrate the impact of Bolivian natural gas exports to Brazil. First, there is a deficit in Bolivia's commercial balance (exports minus

\footnotetext{
${ }^{120}$ Interview which took place between SEP and NOV 2017.

${ }^{121}$ Interview which took place between SEP and NOV 2017.

${ }^{122}$ Interview which took place between SEP and NOV 2017.
} 
imports) with Brazil during the 1990s. Owing to an increase in exports of natural gas to Brazil after 1999, as well as an increased price for the commodity, the economic situation clearly improved for Bolivia.

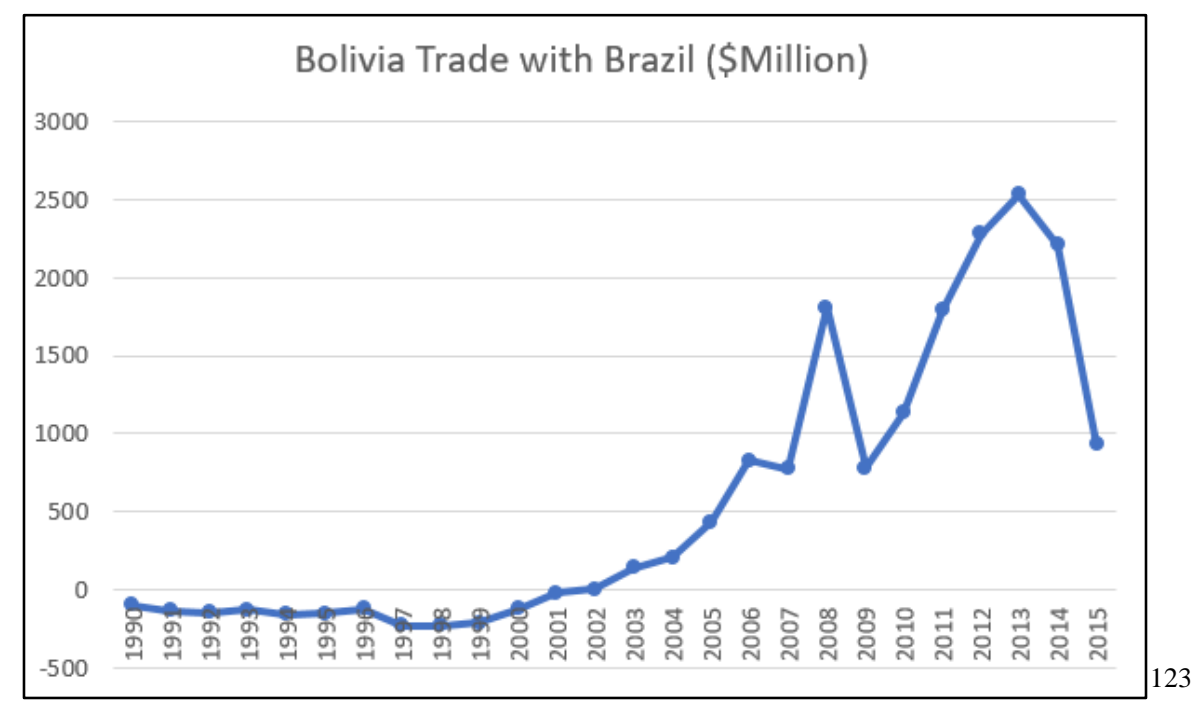

Graph 44: Bolivia Trade with Brazil (\$ Million)

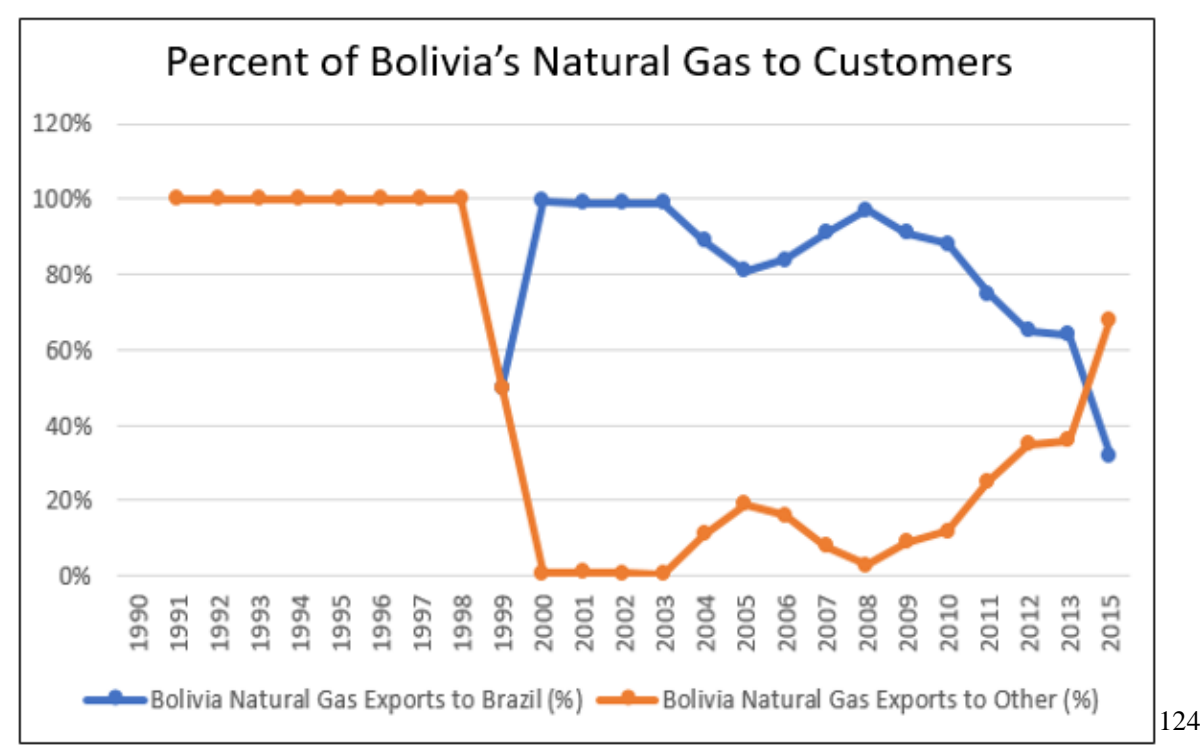

Graph 45: Percent of Bolivia's Natural Gas to Customers

${ }^{123}$ MIT. Atlas. http://atlas.media.mit.edu. Accessed 1 September 2017

${ }^{124}$ MIT. Atlas. http://atlas.media.mit.edu. Accessed 1 September 2017. 


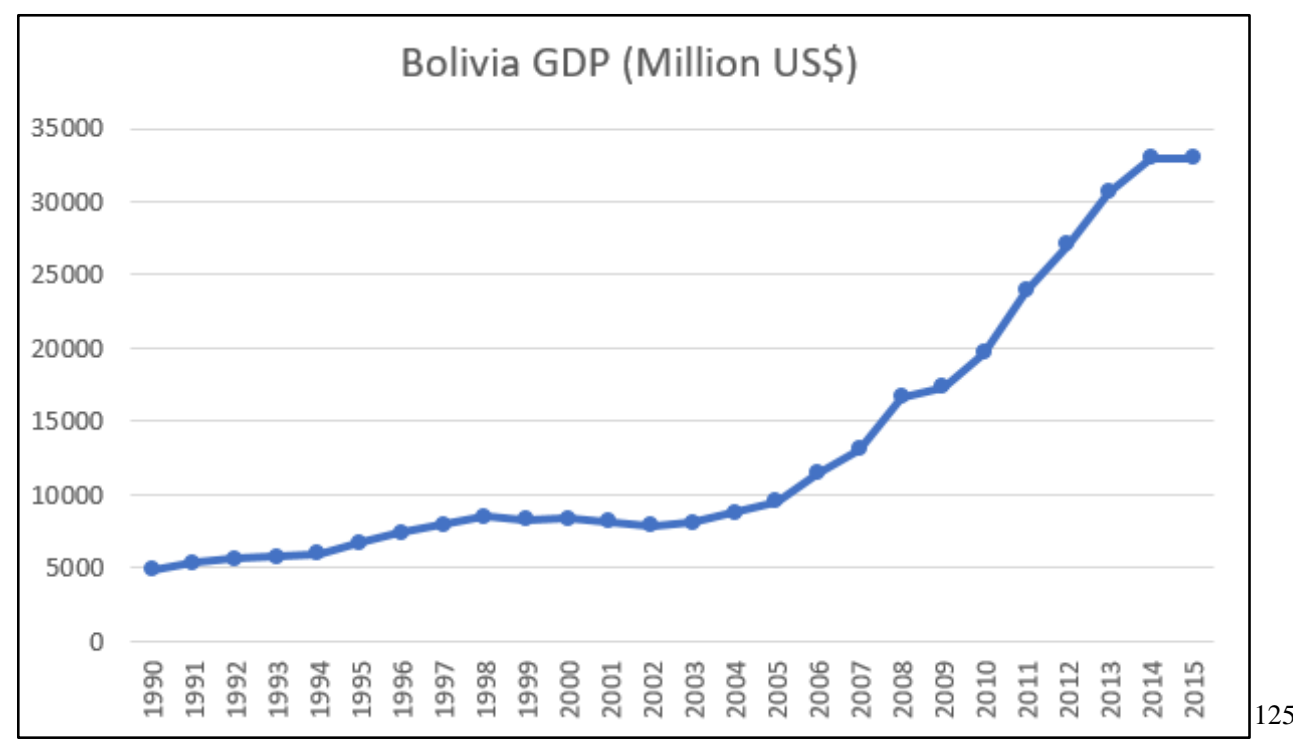

Graph 46: Bolivia GDP (Million \$)

The change in Bolivia's GDP from 1991-2015 is largely based on its exports of natural gas to Brazil (see Graph 46, above). Exports of natural gas to Brazil came at a time when the price of natural gas, often linked to the price of oil, increased. However, there is a downside to such windfalls as Bolivia's natural gas revenues are highly volatile, historically ranging from $\$ 600 \mathrm{M}-\$ 2,700 \mathrm{M}$, and there is a need to make natural gas rents more transparent, as well as to change the way these rents are spent. Royalties are vital for Bolivia and fluctuate based on elasticity of demand (Dussan 2004, 64). Moreover, such rents are a finite resource and there needs to be priority in spending, fiscal discipline in the country, investment in YPFB, and sustainable investment in the productive sectors of the economy. For example, natural gas royalties have been used to develop

${ }^{125}$ MIT. Atlas. http://atlas.media.mit.edu. Accessed 1 September 2017. 
departments within Bolivia, including improvements in electrification and roads;

however, health spending is low, and there remains the additional need to reduce poverty (Medinacelli 2007, 4). It is only logical to appreciate the looming instability facing Bolivia once associated hydrocarbon revenues cease to contribute as much as during commodity booms. According to interview subject 25800-202, the 2005 Direct Tax on Hydrocarbons (IDH) law in Bolivia is the main source of fiscal revenue for the country and the associated harvesting of these rents has already taken place. ${ }^{126}$

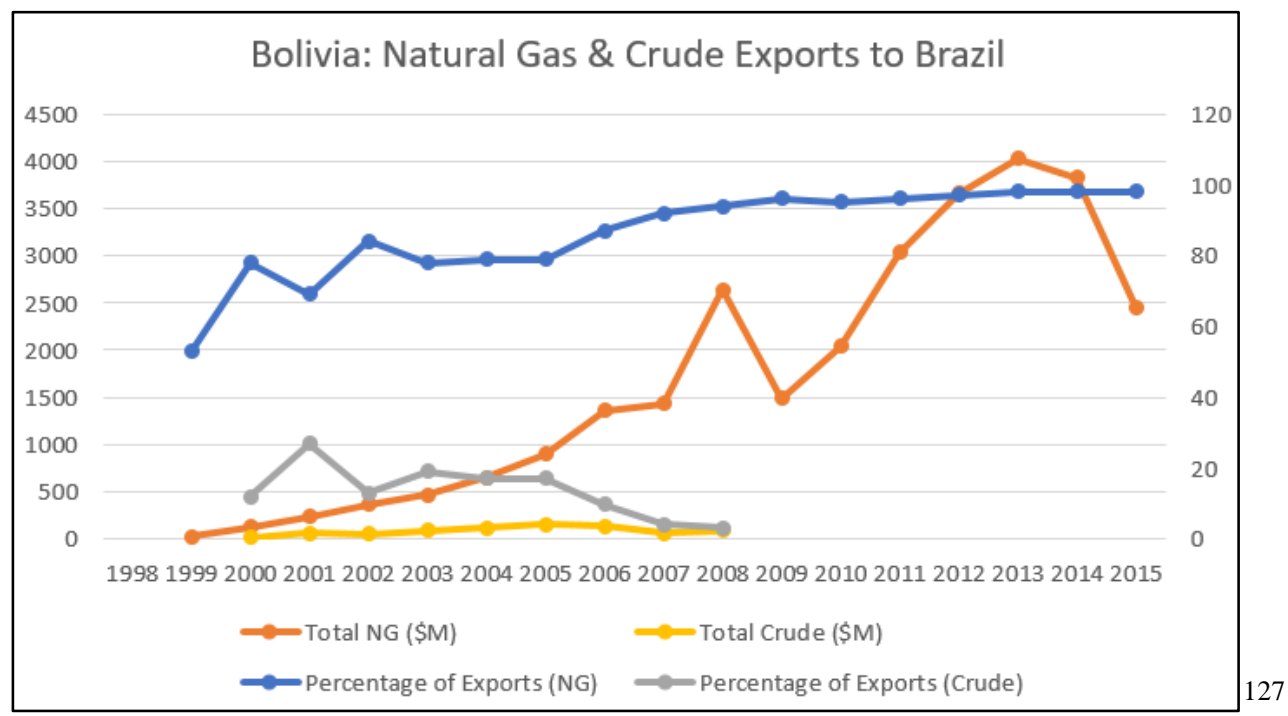

Graph 47: Bolivia Natural Gas and Crude Exports to Brazil

Graph 47 (above) demonstrates the trend of Bolivia as a natural gas and crude oil exporter to Brazil, with the former commodity larger in both percentage and real terms. Again, there is an important shift in revenues after 2005. According to interview subject

\footnotetext{
${ }^{126}$ Interview which took place between SEP and NOV 2017.

${ }^{127}$ Atlas MIT Database. http://atlas.media.mit.edu/en/. Accessed 26 August 2017.
} 
25800-202, for Bolivia to maintain its natural gas revenues, the system must be restructured to encourage IOC exploration, and Bolivia must open its economy if it is to further develop its resources. Moreover, at the domestic level, Bolivia's IDH is too high as well as not progressive in nature, and the associated spending of natural gas revenues provided a great boom for the economy; however, this is because the markets and reserves were already there. ${ }^{128}$

Graph 48 (below) represents the yearly mean average in \$/MMBtu natural gas, based on the Henry Hub (HH) benchmark for North America. The HH benchmark is a guideline for determining prices in South America; however, the exact price at which Bolivia sells natural gas to Brazil is not entirely clear. Ieda Gomes demonstrates the price Brazil pays for Bolivia's natural gas is almost double that of HH (Gomes 2014; Honore 2016). This very important point holds substantial consequences for determining the true value of Bolivia's natural gas revenues and overall GDP. Additionally, findings for the price of wellhead exports to Brazil and Argentina was $\sim$ 10/MMBtu, while the price for internal consumption was $\sim \$ 1$ MMBtu (ABS Consulting Group 2013, 73, 91). At many times less than its export price, it is in Bolivia's economic interest to sell abroad, especially if their internal market is unable to consume all gas produced.

${ }^{128}$ Interview which took place between SEP and NOV 2017. 


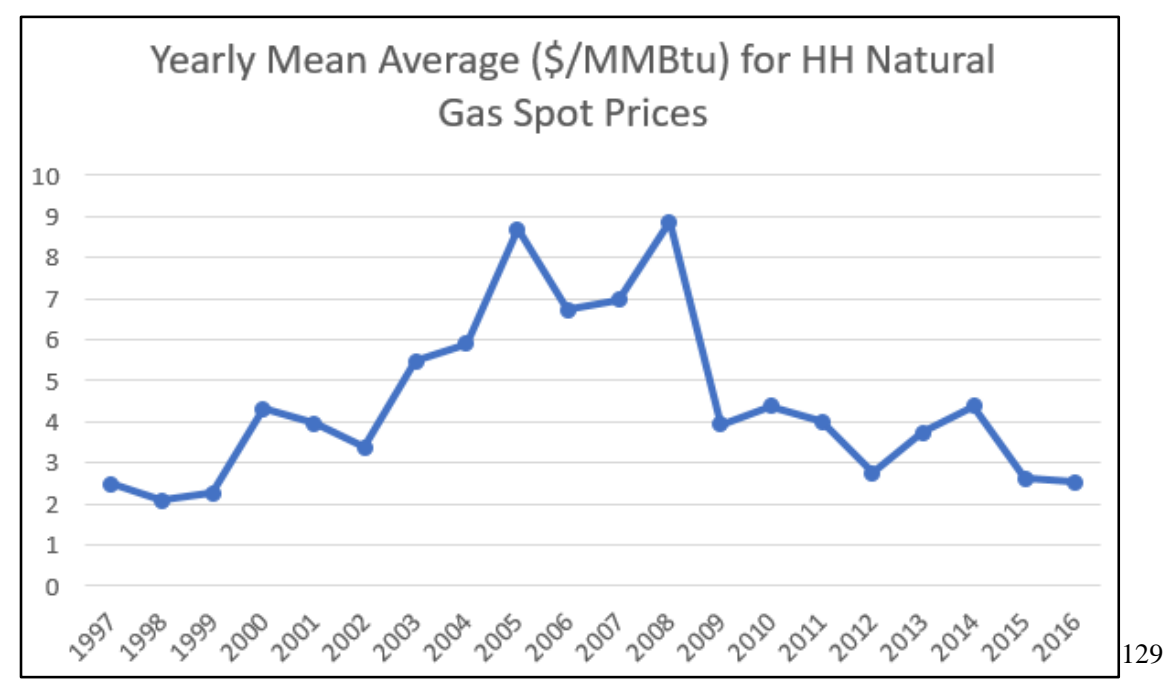

Graph 48: Yearly Mean Average (\$MMBtu) for Henry Hub Natural Gas Spot Prices

Bolivia earns considerably more exporting natural gas, which makes it difficult to economically justify use in domestic consumption (see Graph 49, below). The HH benchmark for natural gas decreased after 2009; however, both Argentina and Brazil pay prices for Bolivian natural gas which resemble what is paid for the commodity in Asia (Gomes 2014; IEA 2016; YPFB 2014; YPFB 2016). Price data for Bolivian internal consumption is spotty. Taking the conservative estimate that Bolivia's natural gas price remains constant for the above period, it remains clear there is greater economic incentive to export than to sell domestically. Additionally, Bolivian gas is costly compared to that of the Brazilian variety because of high transport costs which make the former $40 \%$ more costly than the latter (Fagundez de Almeira 2004, 82). Considering transportation costs combined with the disparity in price of the increased cost of exploration and development

\footnotetext{
${ }^{129}$ Energy Information Administration; https://www.eia.gov/dnav/ng/hist/rngwhhdA.htm; Accessed 20 January 2018.
} 
after the Bolivian 2005 Hydrocarbon Law, IOCs clearly see investment in Bolivia as unattractive. Ultimately, the issue of price is muddled and difficult to resolve, which demonstrates the inherent complexity of viewing natural gas integration in simple macroeconomic terms.

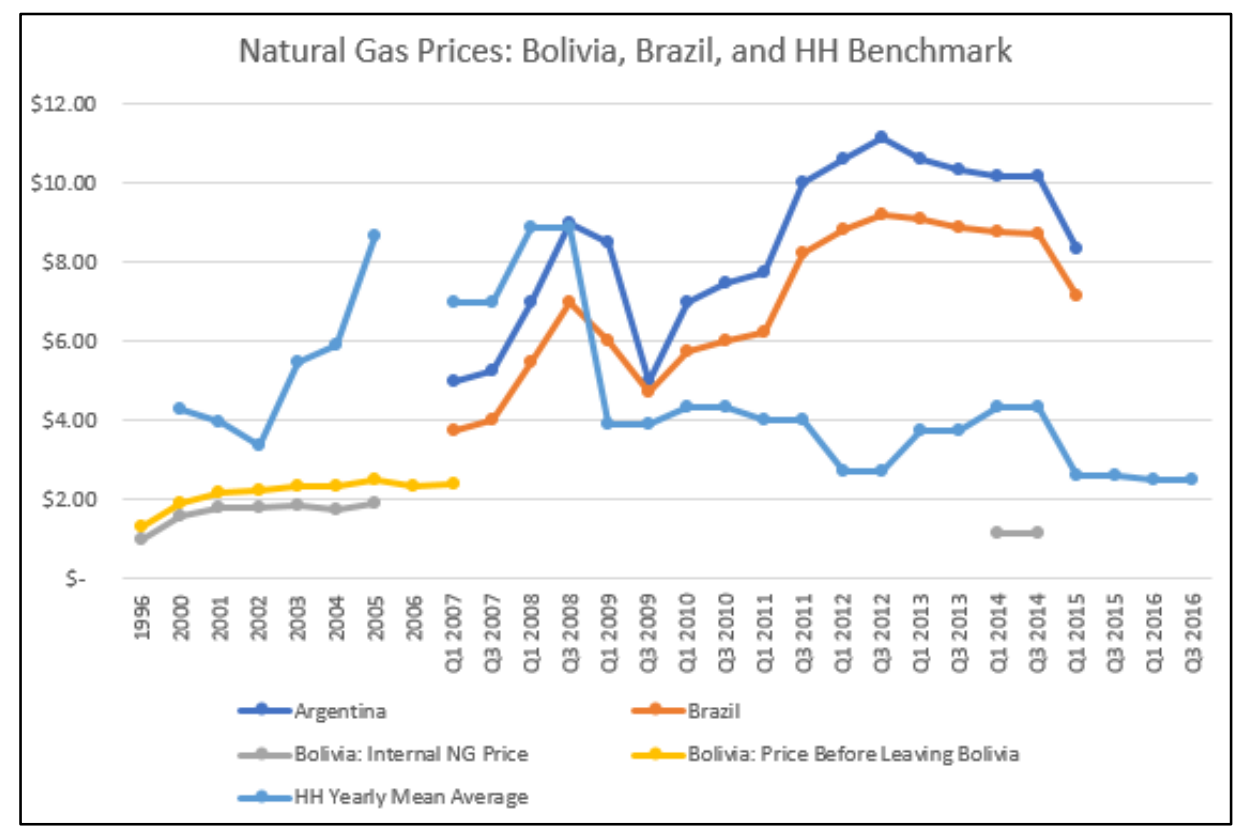

(Glachant 2009; Prates 2006; Honore 2016; Gomes 2014; IEA 2016; YPFB 2014; YPFB 2016)

Graph 49: Natural Gas Prices for Bolivia, Brazil, and Henry Hub Benchmark

According to the below data (overlaid on Graph 50, below), there was a sharp increase in natural gas spot price (\$/MMBtu) from 2003 through 2009, particularly during 2005. This increase, coupled with the increase in royalties, allowed Bolivia to experience an increase in natural gas revenues. 


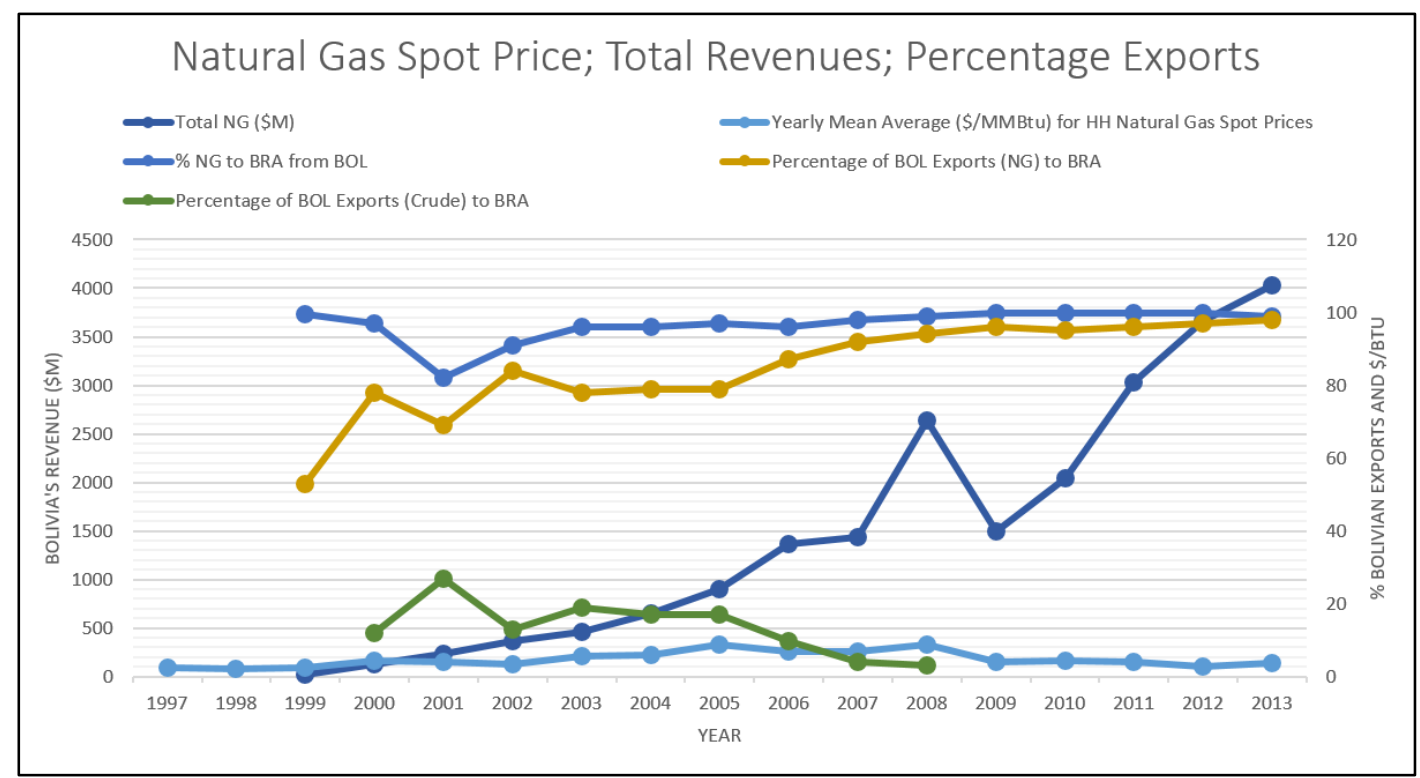

(Glachant 2009; Prates 2006; Honore 2016; Gomes 2014; IEA 2016; YPFB 2014; YPFB 2016)

Graph 50: Natural Gas Spot Price, Total Bolivia Revenues, and Bolivia Percentage Exports

However, when we look more closely at natural gas exports and associated revenues, the story becomes increasingly interesting. Bolivia's proved reserves, production, and price of natural gas show tremendous change after 1999 (see Graph 51, below). There are also subsequent shifts in production and price prior to the 2006 nationalization of Bolivia's hydrocarbon sector. According to interview subject 25800202, the natural gas agreement between Bolivia and Brazil was 25 years in the making, and transcended governments and politics. The intensity of the project increased in the 1990s, as the goal of five Bolivian presidents' pursuit of natural gas integration with Brazil was ultimately realized (Banzer, Siles Zuazo, Paz Estenssoro, Paz Zamora, Sanchez de Lozada, and Banzer again). ${ }^{130}$

${ }^{130}$ Interview which took place between SEP and NOV 2017. 


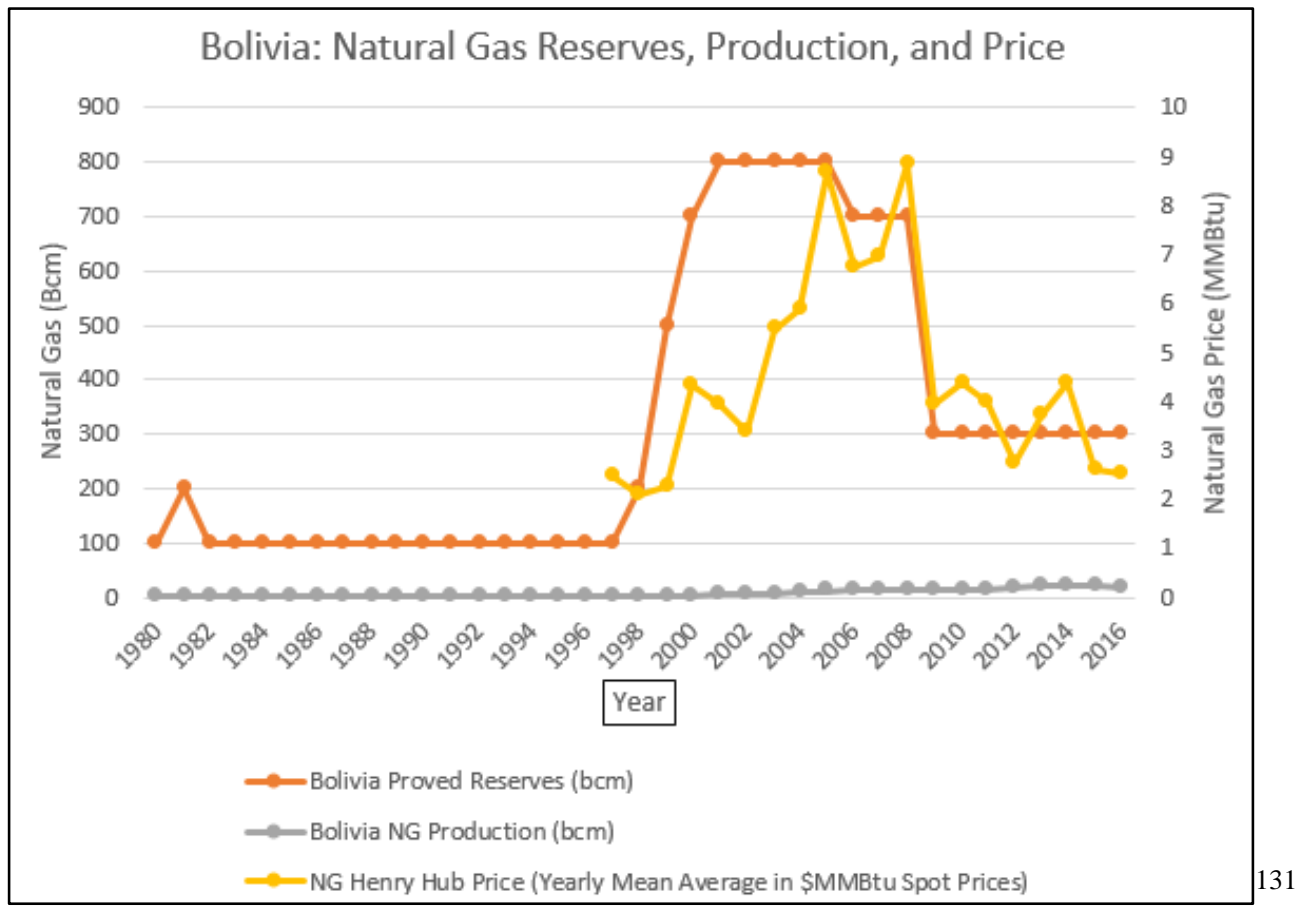

Graph 51: Bolivia Natural Gas Reserves, Production, and Price

Below, with the production of natural gas extrapolated for context relative to its price, there are two major shifts (see Graph 52). First, after 1999, there is an increase in production when the Bolivia-Brazil pipeline came online. Second, there is an additional shift upward between 2000 and 2004, when the amount of natural gas produced almost tripled. Juxtapose this increase with the associated increase in natural gas price, and the post-2005 increase in royalties under the hydrocarbon law and the Bolivia natural gas trifecta is clear.

${ }^{131}$ BP Statistical Review of World Energy 2017; U.S. Energy Information Administration. 


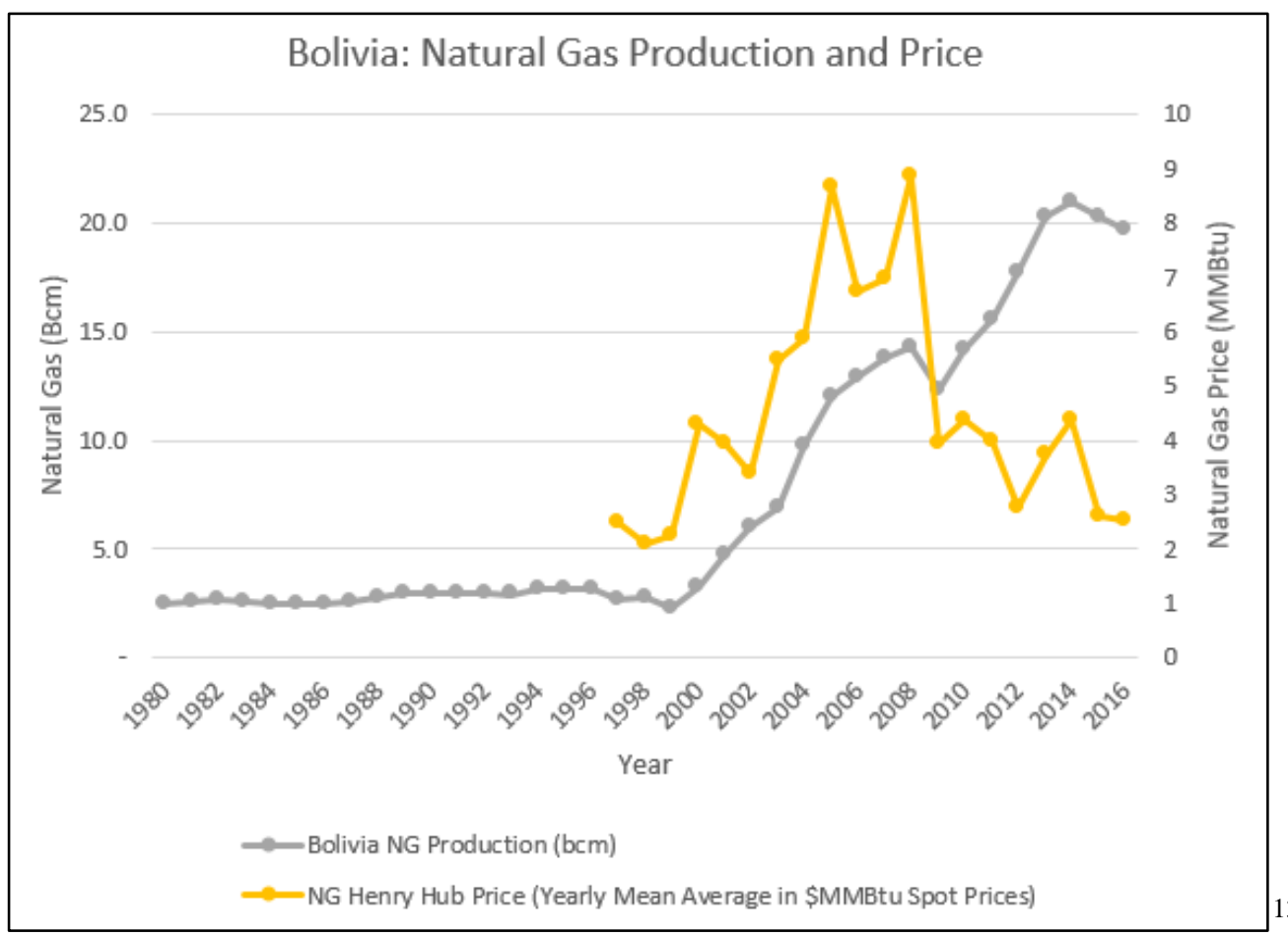

Graph 52: Bolivia Natural Gas Production and Price

President Morales has essentially taken advantage of the dual benefits of increased natural gas prices alongside laws enacted prior to his election. While claiming credit for the natural gas resource boom in Bolivia, Morales has simultaneously decried the behavior of past neoliberal governments. Interestingly, these very same governments provided the foundation for Bolivia's strong economic growth, Morales' concomitant political success, and resultant social spending. Bolivia's combination of increased natural gas production, substantial increase in the price of natural gas, and increase in percentage of royalties from the 2005 Hydrocarbon Law were all events that either preceded or were in their ascendant before Morales' election.

\footnotetext{
${ }^{132}$ BP Statistical Review of World Energy 2017.

${ }^{133}$ Energy Information Administration; https://www.eia.gov/dnav/ng/hist/rngwhhdA.htm; Accessed 20 January 2018.
} 
However, unless additional exploration and investment in the natural gas sector takes place, Bolivia may find itself experiencing a situation of diminishing returns relative to gas exploitation and subsequent sales to its coveted Brazilian market. Presently, it is too costly for IOCs to operate in Bolivia, and unless there is a change, Bolivia may soon face declining production, which will have secondary and tertiary effects on revenue and spending. Presently, the hydrocarbon "pie" breaks down into royalties (18\%), IDH (32\%), an unknown percentage for YPFB, and the remaining percentage for the private operator to cover costs. The $18 \%$ of royalties are further divided between the producing department and the Treasury. The $32 \%$ derived from IDH divides among various entities in Bolivia: municipalities, universities, Treasury, Indigenous Fund, etc. (Medinacelli 2015, blogpost \#63).

Ultimately, if additional IOC investment into Bolivia's natural gas production does not appear, it is possible the country will face diminishing returns on its natural gas revenue. Moreover, the potential of Brazil developing its own natural gas reserves may deny Bolivia its most secure market. It is likely Bolivia will be forced to rescind, or severely adjust aspects of, its 2005 Hydrocarbon Law if it wishes to attract IOCs to develop additional natural gas reserves.

For historical context, it was only one decade prior to the 2005 Hydrocarbon Law when a national referendum supported increased royalties on gas production, making them the 50\% rate of today (Dussan 2004, 66). Increased taxes and royalties stifled exploration and development. It appears that just over ten years after Bolivia's nationalization of its hydrocarbon resources, the time has come to consider changes that will attract needed private capital investment. 
According to interview subject 25800-209, arguably FDI drops or declines under populist governments, which presents problems for development. "In Bolivia, there is plenty of natural gas as well as tungsten, tin, silver, and the like. Presently, Morales, who I consider to be a smart man, is posturing for reelection and attempting to establish additional trade relationships in the region. Bolivia remains challenged to compete in this environment, though, as it is surrounded by economic giants, regionally speaking of course. Bolivia wants a piece of this market, too, and is focusing on opening its market despite Morales' 'socialism."'134

Last, and tangential to energy integration, although Bolivia is considering the export of electricity, this is an unlikely scenario as countries prefer to import hydrocarbons and produce electricity on their own. According to interview subject 25800-202, electricity integration in South America exists, but governments prefer to buy oil or gas, and then convert the resources into electricity on their own. "This is because countries do not want to give up their power of electricity to another state or country..."135 Instead, governments prefer to purchase natural gas or oil because there are many markets from which to choose. "Electricity imports may work in Central America because the region is one market, where all countries are energy importers. Former President of Venezuela, Hugo Chavez, was successful in Central America because he provided much needed supplies to the region in exchange for U.N. votes and leftist promotion." "136 The decision to import resources instead of finished electricity is

\footnotetext{
${ }^{134}$ Interview which took place between SEP and NOV 2017.

${ }^{135}$ Interview which took place between SEP and NOV 2017.

${ }^{136}$ Interview which took place between SEP and NOV 2017.
} 
likely rooted in a state's desire to control its electricity production. Hypothetically, if a country relies on a neighbor for its electricity, it may be held hostage should there be political instability, or if the provider decides to leverage its political power over a country or an entire region.

\section{Brazil}

What follows is a brief discussion of Brazil's energy matrix, as well as macroeconomic indicators to place the country and natural gas relationship with Bolivia into context. Brazil's energy matrix is much more sophisticated than neighboring Bolivia. Brazil's sheer size requires a more complex pipeline network to feed its industrial areas of the South and Southeast, as well as to deliver energy to develop the interior. The quantity of energy consumed by Brazil accounts for over $50 \%$ of South America's demand. Globally as of 2015 Brazil was the eighth-largest energy consumer on the planet and energy consumption has almost doubled in just over the last decade. ${ }^{137}$ The potential development of Brazil's offshore natural gas deposits will likely affect its decision to continue to import natural gas, which will also have implications for the region. The below graph explains Brazil's electricity production by source.

Hydroelectric power is where the bulk of electricity derives (see Graph 53, below). Though, in years of drought Brazil supplements its energy needs with natural gas. Other sources of fuel exist in Brazil's energy matrix, such as nuclear and renewables; however, their use only exceeded $5 \%$ after 2009.

\footnotetext{
${ }^{137}$ U.S. Energy Information Administration; Brazil; https://www.eia.gov/beta/international/analysis.cfm?iso=BRA, November 21, 2017, accessed 29 January 2018.
} 


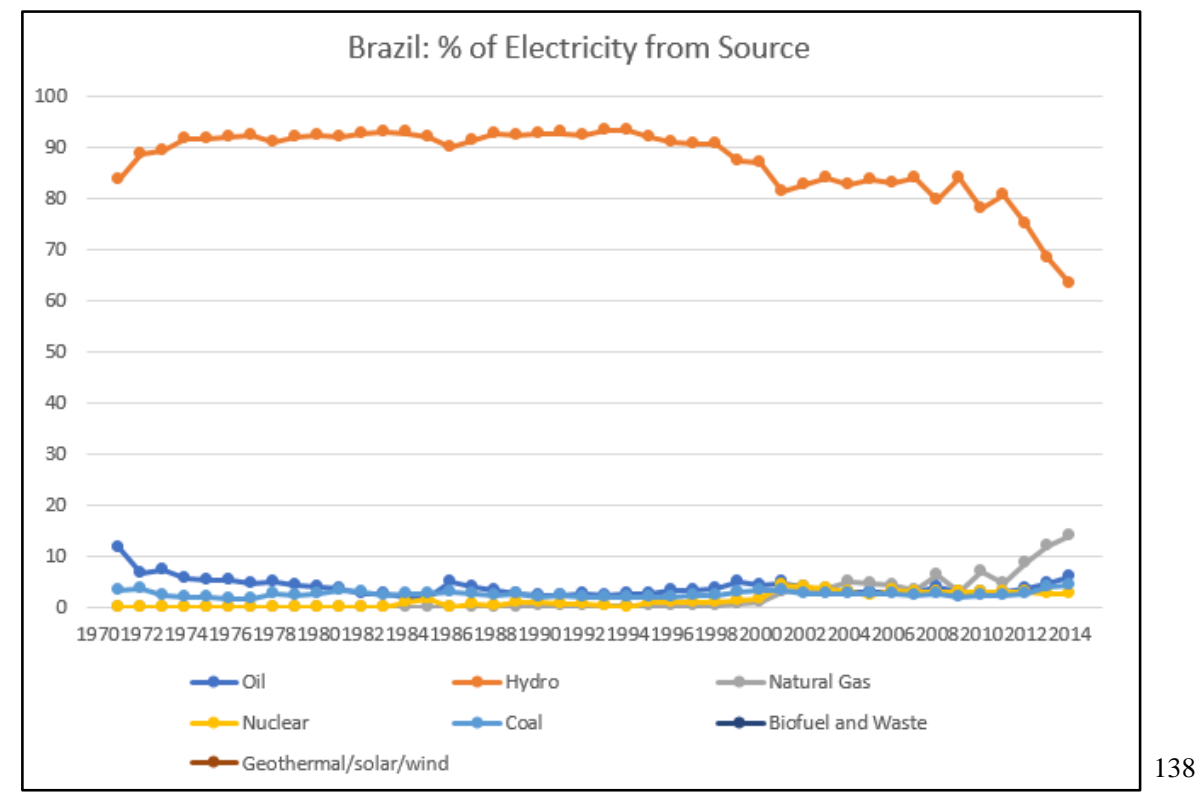

Graph 53: Brazil Percentage of Electricity from Source

Brazil imports Bolivian natural gas at a higher rate than Argentina, another regional supplier (see Graph 54, below).

${ }^{138}$ World Bank.

http://data. worldbank.org/indicator/EG.ELC.FOSL.ZS?end=2014\&locations=BR\&start=1971\&view=chart. Accessed 28 January 2018. 


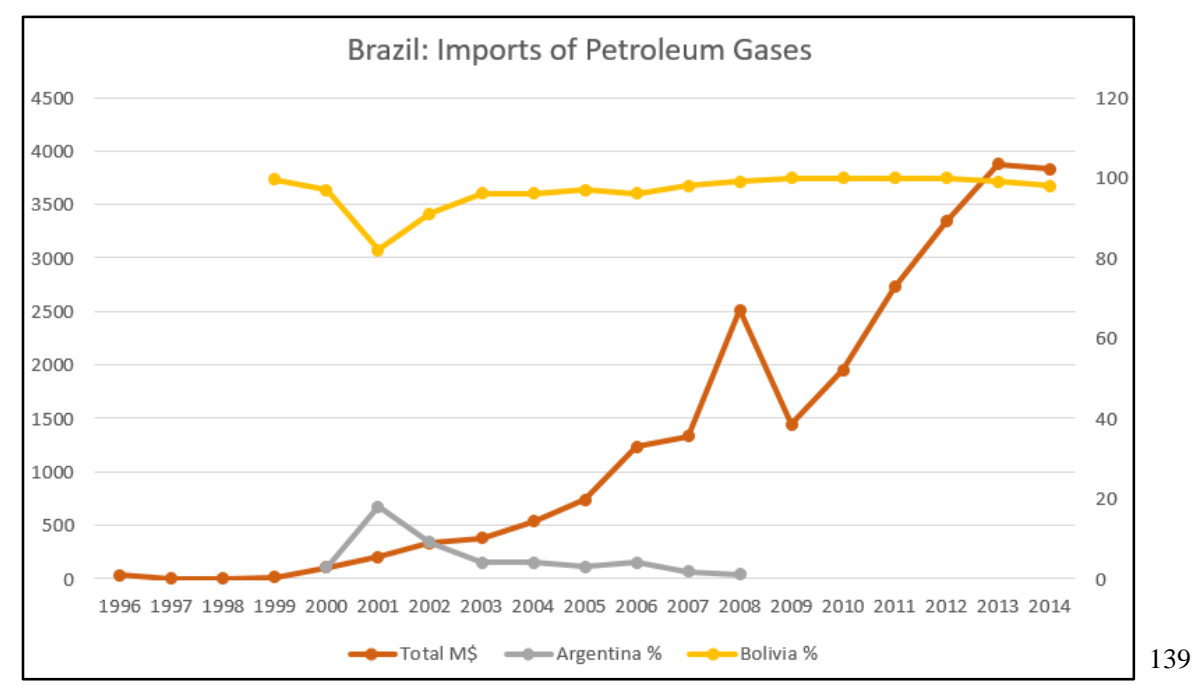

Graph 54: Brazil Imports of Petroleum Gases

Brazil's development of its hydrocarbons has waned because of a lack of internal reforms and infrastructure bottlenecks (Gomes 2014,4). The Petrobras monopoly over the hydrocarbon sector also inhibited development. In 1995 this monopoly ended via constitutional amendment, and in 1999 under the Cardoso administration the government began to gradually liberalize the oil and gas sector by subjecting all public services to competitive bidding. Additionally, the 2009 Gas Law further reduced Petrobras control over the sector. By 2013, there were over 70 private companies active in the upstream, operating alone or in conjunction with Petrobras, with the bulk of produced gas also sold to Petrobras. Presently there are over 90 companies, both local and foreign, that hold exploration areas in Brazil (ANP 2016). Nevertheless, natural gas now accounts for roughly $15 \%$ of domestic supply because of hydropower preponderance and relatively undeveloped natural gas infrastructure.

139 Atlas MIT Database. http://atlas.media.mit.edu/en/. Accessed 26 August 2017. 
The history of natural gas in Brazil dates to the mid- $19^{\text {th }}$ century, with the creation of the Rio de Janeiro Gas Company (later renamed State Gas Company, CEG) in 1854. The creation of the Sao Paulo Gas Company (COMGAS) came about in 1872. Several others came about between then and the early 1900s; however, the advent of electricity resulted in the collapse of all city gas companies except CEG and COMGAS (Gomes 2014, 7).

The Brazilian populist Vargas created the National Oil Council (CNP) in 1934 and, although weak, the organization still carried out a geological survey of Brazil. Several years later, the "Oil Is Ours" campaign began, and lasted until Law 2004 was enacted (1952), which granted a monopoly of oil exploration to Petrobras. Later, the military attempted to solve the oil problem and its effects on Brazilian economic development. Brazil still operated on firewood as late as 1967, and if the county was to industrialize, it needed to make oil central to its energy policy (Biasetto 2016, 6). Brazil's energy policy was directly related to its development policy.

A few years after the military dictatorship began, Brazil experienced an economic miracle, resulting from planning carried out by the military regime and economists. During this period (1967-1974), Brazil was out of money, but given support from the U.S. (Lyndon Baines Johnson administration) in efforts to fight communism (Biasetto 2016, 23). Nevertheless, during this time, Brazil remained weak, and lacked a clear strategy to confront its energy challenges. The oil shock of 1973 ended Brazil's initial phase of ISI, and the subsequent 1979 oil shock did not help Brazil maintain its footing.

In 1974, Brazil was under the Geisel presidency which managed the economic plan developed in 1964, and began to ease the dictatorship. In fact, oil shaped the Geisel 
presidency, and was also blamed for the 1980s debt crisis. During the middle-1970s, Brazil was still importing $40 \%$ of its energy needs, and Geisel emphasized the development of nuclear, alcohol, and hydropower energy sources. Such an expansion was facilitated by foreign financial markets (Geisel was not opposed to foreign investment, but did not trust foreign companies), eager to extend credit (Biasetto 2016, 104). By this time, Geisel was facing a change in Brazilian development from ISI to export substitution as the country shifted from an exporter of agriculture to industrial goods, which was a serious challenge as Brazil had not yet resolved its energy supply situation, which was largely imported. Despite Geisel's patriotism, he was under great pressure to open Brazil's oil fields to the majors. At the time, proponents of the freemarket in Brazil conceded that Petrobras was a costly failure, and there was a need to enter into risk contracts with the major oil companies. ${ }^{140}$ The majors could drill, but were required to sell all discovered oil to Petrobras (Biasetto 2016, 162).

Later, the strategy was to increase the use of natural gas in the Brazilian energy portfolio, and Cardoso saw this resource as a way to fuel Brazilian industry. Brazil signed gas deals with Argentina and Bolivia, with the latter's pipeline coming online at the beginning of Cardoso's second administration (1999-2002) (Silva 2009, 206). More recently there has been a steady increase in natural gas consumption in Brazil, particularly after the pipeline linking Bolivia to Brazil in 1999 was completed, a true game changer for the region (see Graph 55, below).

\footnotetext{
${ }^{140}$ The lack of a guarantee of certain profits are what made these agreements risk contracts.
} 


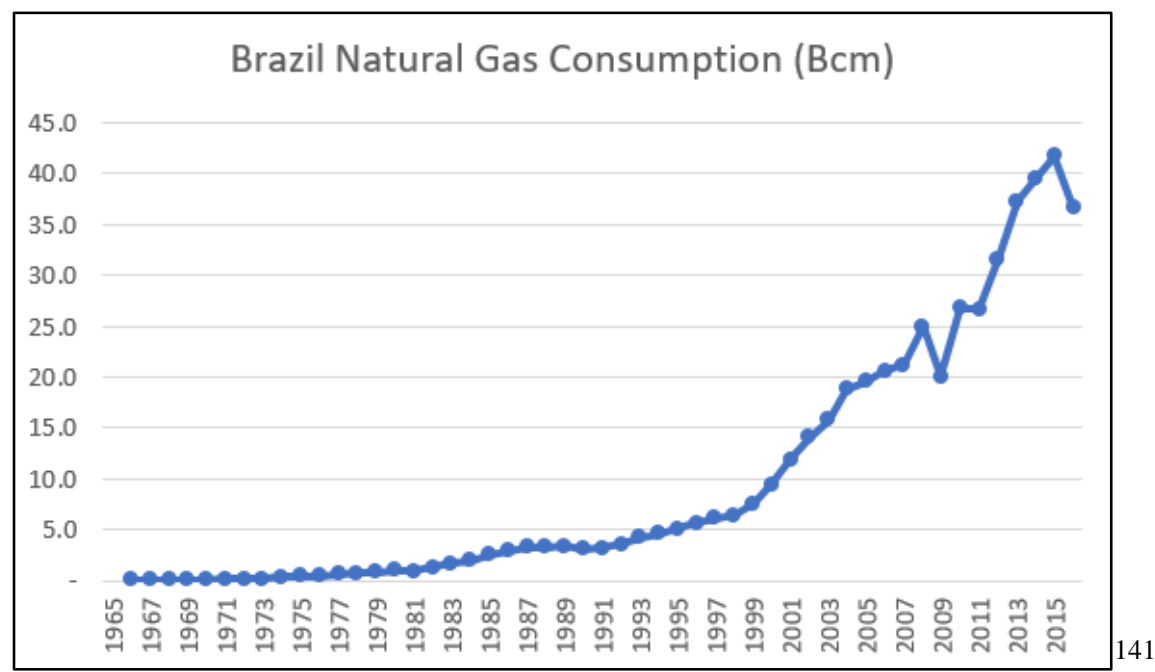

Graph 55: Brazil Natural Gas Consumption (Bcm)

Brazil's pre-salt discoveries, if developed, will likely result in great opportunities amid substantial growth in its upstream; the underlying assumption is that the pre-salt discoveries of recent years (Santos and Campos Basins) will result in increased outputs of both crude oil and natural gas. According to interview subject 25800-206, "Brazil's presalt discoveries were used to pay for everything, but the Brazilians spent the money before it was earned. Certainly, some folk were brought out of poverty during the Lula and Rousseff period, but these same people are now falling back into it because there was not sufficient and sustainable investment in education, health, and other social services." Regarding economic development, “... at least under the dictatorships there was development progress; however, since Lula, there is nothing to show for investment in the productive or manufacturing sector of the economy despite billions flowing into the country from China." 142

\footnotetext{
${ }^{141}$ BP Statistical Review of World Energy 2017.

${ }^{142}$ Interview which took place between SEP and NOV 2017.
} 
As in the previous section on Bolivia, a closer look is warranted. In Graph 56 (below) of Brazil's proved reserves, production, and price of natural gas, we can see tremendous change after 1999, then subsequent shifts in production and price prior to the 2006 nationalization of Bolivia's hydrocarbon sector, and finally an uptick in production after Brazil's 2009 Gas Law (11909). The intensity of the project increased in the 1990s, as the goal of several Brazilian presidents' pursuit of natural gas integration with Bolivia was ultimately realized, and then maintained (Collor de Mello, Franco, Cardoso, Lula, and Rousseff).

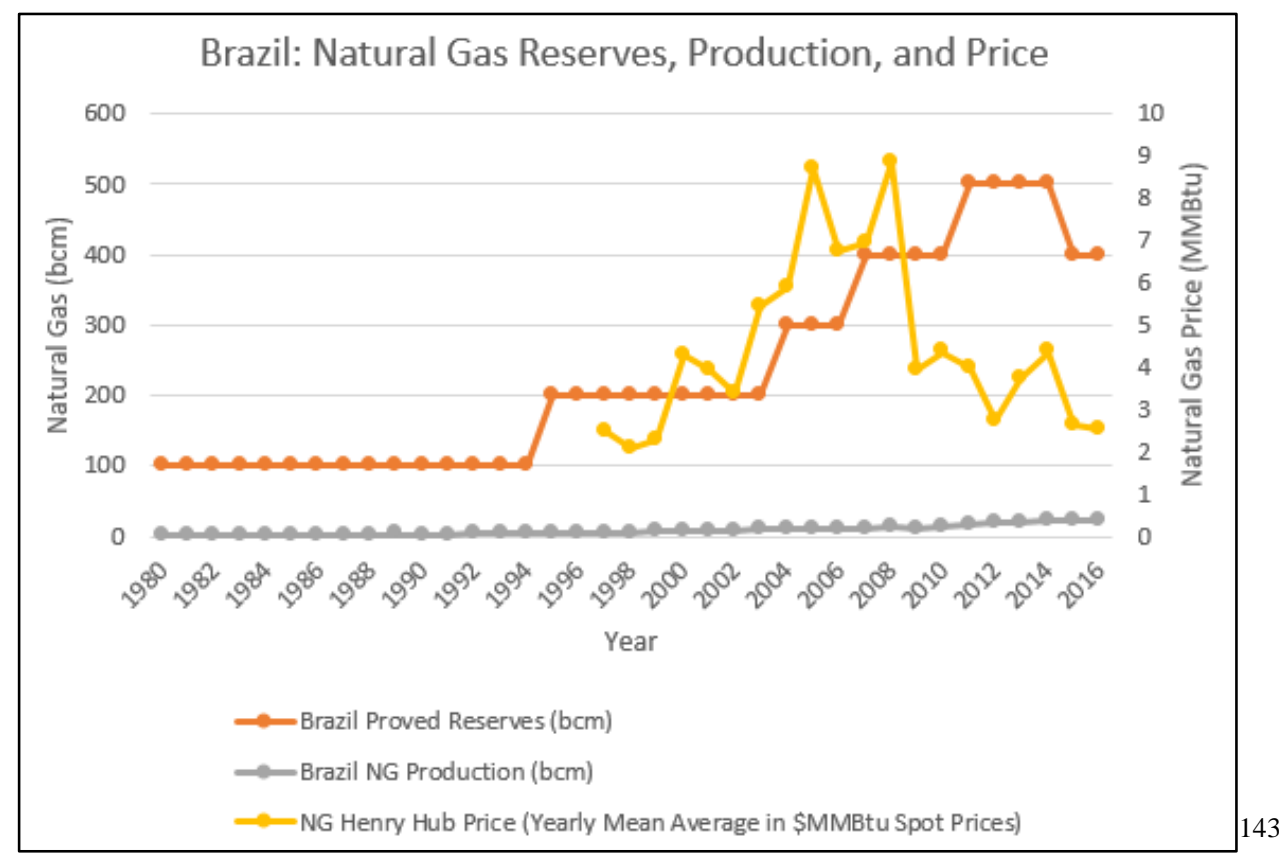

Graph 56: Brazil Natural Gas Reserves, Production, and Price

With the production of natural gas extrapolated for context relative to its price, there are two major shifts (see Graph 57, below). After 1999, there is an increase in

${ }^{143}$ BP Statistical Review of World Energy 2017. 
production when the Bolivia-Brazil pipeline came online. Second, there is a major shift upwards after 2009 when Brazil's Gas Law passed. Brazil's production of natural gas doubled from 2009-2016.

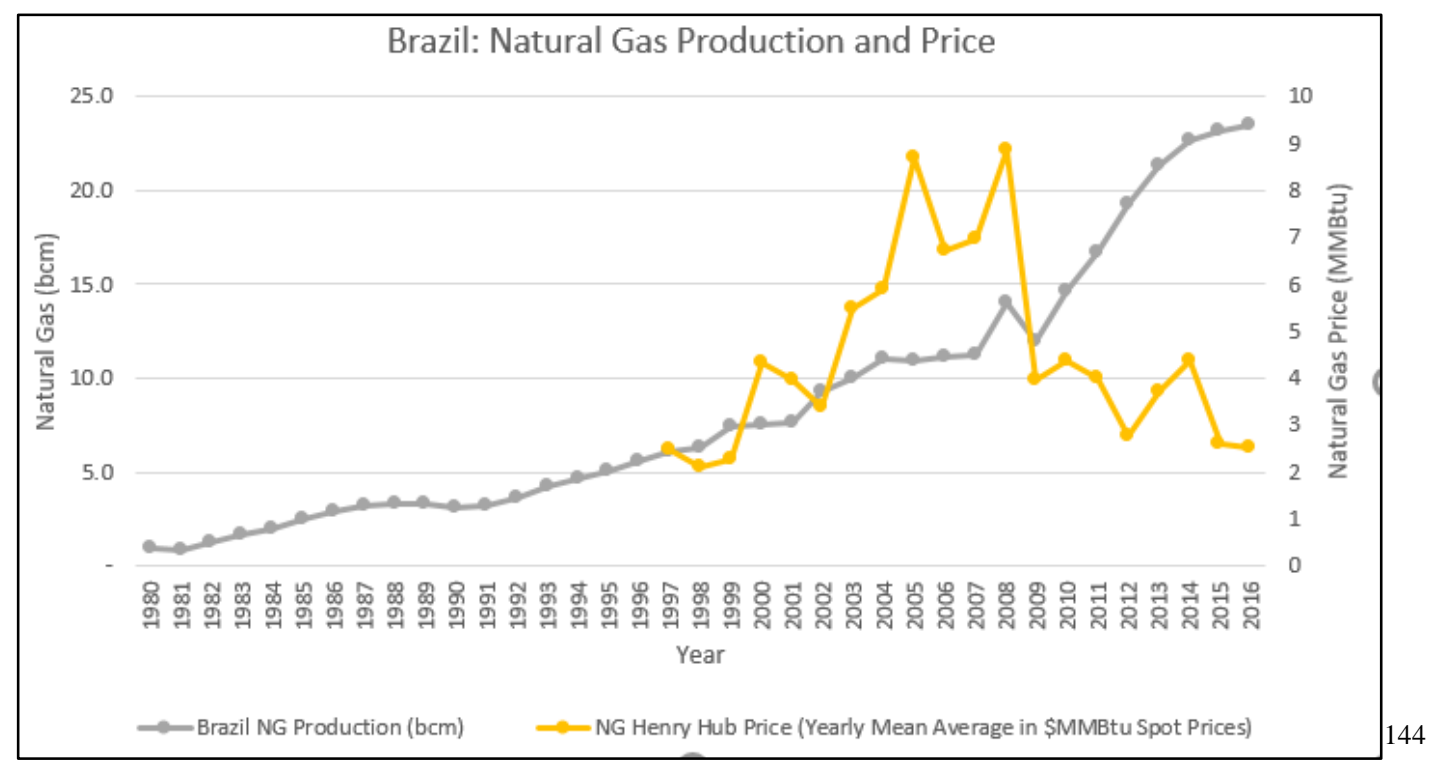

Graph 57: Brazil Natural Gas Production and Price

A downside has been as Brazil increased output there has been a decrease in revenue because of lower oil prices. According to interview subject 25800-206, Brazil is natural gas self-sufficient on paper, or is projected to become so, but this is not truly the case. Development is costly, and despite Brazil's advances in deep-water drilling, it is unlikely to develop its resources. Instead, Brazil is politically inept and will absolutely require the help of IOCs to develop its pre-salt resources. Moreover, the recession in the

${ }^{144}$ BP Statistical Review of World Energy 2017. 
country combined with the fallout from the Car Wash scandal inhibits Petrobras success, and by extension much of that of Brazil. ${ }^{145}$

Brazil will remain a natural gas importer for the foreseeable future, and instead focus on developing its strong oil sector. However, the ongoing fallout from the Car Wash corruption scandal, to include project delays, tempers some of this optimism. The ascension of Michel Temer to the presidency will presumably bring to Brazil a more investment-friendly environment to the oil and gas sector. The CEO of Petrobras, Pedro Parente, is naturally business-friendly and will likely provide additional optimism and stewardship as the parastatal rides out the scandal. ${ }^{146}$ Nevertheless, a loss of confidence in Petrobras could entice investors away from Brazil and toward other hydrocarbon markets in Latin America. Despite this potential, Brazil will certainly remain a major player in the region. The relationship between Bolivia and Brazil does not exist in a vacuum, however. If Brazil elects to develop its offshore reserves, it may decide to continue to purchase Bolivian gas for some time. If so, Brazil will be able to negotiate with Bolivia from a position of strength.

Non-economic considerations may contribute to the calculus of Brazilian decision-makers. According to interview subject 25800-204, the discovery of gas and oil deposits off Brazil's coast is definitely a game changer, but has some second and third order effects, and such considerations weigh heavily in the minds of Brazilian planners. "There is a pre-existing concern in the Brazilian government of Bolivians moving into the country in search of better opportunities, and the Brazilians do not care for such

\footnotetext{
${ }^{145}$ Interview which took place between SEP and NOV 2017.

146 Parente resigned from Petrobras in June 2018, after a national trucker strike took place during May 2018. The board of Petrobras named Chief Financial Officer, Ivan Monteiro, as interim CEO.
} 
migratory movements. Even though Brazil may eventually become self-sufficient in natural gas, Brazil may continue to purchase Bolivian gas to not weaken the Bolivian economy as such a situation will likely result in increased Bolivian immigration into Brazil." Brazil considers the "minor expense" of Bolivian natural gas as acceptable to avoid what it considers a potential demographic shift. ${ }^{147}$ This sentiment is partly corroborated by interview subject 25800-209, who posits that countries in the region such as Argentina, Brazil, and Chile are skeptical about helping less stable countries like Bolivia. These countries see migration out of Bolivia as a concern and may be compelled to apply pressure on the government of Bolivia to control or stop migratory outflows. There is a need for Bolivia to confront its major internal problems such as coca/cocaine, free movement of drug trafficking organizations, its indigenous social issues, myriad economic problems, and poor governance if migration is to be better managed. ${ }^{148}$

The initial development of the natural gas market in Bolivia was arguably not purely market-driven or indigenous in nature. Brazil's decision to continue to buy Bolivian natural gas may not purely be driven by price or need.

\section{Toward the Future: The Natural Gas Relationship between Bolivia and Brazil}

It is likely the natural gas relationship between Bolivia and Brazil will continue, regardless of who becomes president of either country, whether resource nationalist and populist or neoliberal in their views on integration. For example, according to interview

\footnotetext{
${ }^{147}$ Interview which took place between SEP and NOV 2017.

${ }^{148}$ Interview which took place between SEP and NOV 2017.
} 
subjects 25800-201, 25800-203, 25800-204, 25800-205, 25800-206, 25800-207, and 25800-209 populist governments, whether dictatorships or democracies of the left or of the right need to pay the bills, as economic decline often results in a change of government, and nobody wants to lose power. ${ }^{149}$ Additionally, although there appears to be an emerging conflict of vision between Bolivia and Brazil, this was not always the case as the Morales and Lula governments were very close. Continuing, these same interview subjects argue that specific to Morales in Bolivia, and both Lula and Rousseff in Brazil, these individuals have become part of the same system they spent their lives or careers fighting against, as the policies they once despised are the same ones they uphold, or even deepen, once in office. ${ }^{150}$

The difference in vision between each country is an important aspect of this study. There is a new paradigm developing in the relationship between Bolivia and Brazil, as well as within the entire region. On one hand, Bolivia will face uncertainty, but an opening of natural gas markets and associated competition may be of benefit to Bolivia rather than the country relying on the present single market of Brazil, a near monopsony. Interview subject 25800-209 points out that regarding trade relationships, Bolivia is at near-dependency on Brazil. However, despite the Brazilian need for natural gas, it is economically growing and developing its own reserves, which will likely result in exports outside of the region as Brazil opens itself to new, external markets. "Bolivia

\footnotetext{
${ }^{149}$ Interview which took place between SEP and NOV 2017.

${ }^{150}$ Interview which took place between SEP and NOV 2017.
} 
will need to adapt to the potentiality of losing Brazil, its main trading partner for natural gas, which will be to Bolivia's great detriment."151

Bolivia will have the option to negotiate with various potential buyers to decrease risk, which will be beneficial despite an associated increase in complexity. Interview subject 25800-209 echoes this sentiment, and maintains that trade is beneficial to both sides of a bilateral agreement; however, the Trans Pacific Partnership is real and this will have yet unforeseen effects on the entire region as well as the fractious MERCOSUR. ${ }^{152}$ On the other hand, the price of natural gas will not be the sole determinant for Brazil. Instead, flexibility will be increasingly important in its natural gas matrix. According to interview subject 25800-208, Petrobras invested in LNG and this market moved very fast. It was the market that drove Brazil to import LNG because of the flexibility in contracts LNG offers. The nature of Brazil's need requires this flexibility more than that of longterm pipeline agreements, as is the case with Bolivia. Brazil requires a diversity of supply in energy sources, and it is this diversity of supply which will allow Brazil to negotiate from a position of strength during upcoming contract negotiations with Bolivia. $^{153}$

Brazil will likely continue to purchase natural gas from Bolivia. However, because of Brazilian pre-salt discoveries, the potential of LNG trade, and new business models developing in Brazil and the region, Bolivia will face increasing pressure to

\footnotetext{
${ }^{151}$ Interview which took place between SEP and NOV 2017.

${ }^{152}$ Interview which took place between SEP and NOV 2017.

${ }^{153}$ Interview which took place between SEP and NOV 2017.
} 
adapt. Moreover, according to interview subject 25800-207, the sheer scale of Brazil's economy dwarfs that of Bolivia. Brazil's market and professional diversity allow it to compete with IOCs on some level, which is not the case at all for Bolivia. Basically, the natural gas discoveries off Brazil's coast will cause Petrobras to begin to look at their development in purely economic or market terms, like IOCs do, and this perspective will benefit Petrobras, but likely not Bolivia. ${ }^{154}$ Continuing in this vein, interview subject 25800-207 maintains that ideally NOCs should integrate themselves more with IOCs as they are more efficient and effective, and have better accountability. People in countries with NOCs often do not trust the parastatal, or often even their own system. Specific to Bolivia, YPFB should not try to compete with the IOCs, but instead work with them as the country has absolutely zero leverage over any IOC. ${ }^{155}$

Brazil is presently in the throes of transition towards a new center-right coalition in the national congress. As a result, the political and business context for natural gas has associated implications relative to competition in the natural gas market. The energy policy in Brazil is market-oriented, as demonstrated through the restructuring of Petrobras, liberalization of price, privatization of assets, and the "Gas to Grow" structural growth program (Brazil Ministry of Mines 2016). These changes may present challenges for Bolivian gas in Brazil.

There are numerous companies in Brazil that want Bolivian gas, which will offset the risk of Bolivia not securing a long-term contract. If Bolivia begins negotiating with

\footnotetext{
${ }^{154}$ Interview which took place between SEP and NOV 2017.

${ }^{155}$ Interview which took place between SEP and NOV 2017.
} 
some buyers it will be able to quickly increase this number. The advantage here is that if one buyer does not want Bolivian gas, there will be others. The solution to market risk in natural gas is the market itself (Fagundez de Almeida May/Jun. 2017). According to interview subject 25800-202, the future of the relationship between Bolivia and Brazil will likely be that the ToP contract between the two countries will decrease to $\sim 100 \mathrm{Mm}^{3} /$ day with an established upper limit of natural gas price possibly close to Henry Hub, and that Petrobras will manage some important Bolivian natural gas fields, as it has done in the past. ${ }^{156}$ Note the $\sim 100 \mathrm{Mm}^{3} /$ day $\left(\sim 36.5 \mathrm{Bm}^{3}\right.$ total $)$ estimation dovetails with the earlier natural gas consumption graphic, a decrease from Brazil's high point in total consumption of over $40 \mathrm{Bm}^{3}$ in 2014 to just over $35 \mathrm{Bm}^{3}$ in 2015. Petrobras, expelled from Bolivia after Morales' nationalization of the hydrocarbon sector, will possibly once again manage some of Bolivia's fields. To substantiate this point, Brazil's total demand is $100 \mathrm{Mm}^{3} /$ day when all terminals are being consumed which breaks down into $55 \mathrm{Mm}^{3} /$ day derived from domestic production with the remainder satisfied by Bolivian imports and LNG (Fagundez de Almeida May/Jun. 2017).

If the long-term nature of Bolivia's ToP contract with Brazil changes because of market fluctuations, a near inevitability, Bolivia will need to adapt to short-term contracts of less than twenty years, or even consider trading natural gas on the spot market as is the case in more nimble markets like the U.S. According to interview subject 25800-208, presently, investors will not invest in Bolivia until they know the outcome of the BoliviaBrazil natural gas contract as investors want to make a profit. If domestic sales are on the

\footnotetext{
${ }^{156}$ Interview which took place between SEP and NOV 2017.
} 
rise in Bolivia, or if they are the only sales of natural gas for Bolivia, then there is less opportunity for profit as gas sales to Brazil will offer a greater return on investments. ${ }^{157}$

A situation of few buyers will make short-term or spot market gas trades very risky for Bolivia as this may also affect government rents. If Bolivian gas is only sold domestically ( $\$ 1 / \mathrm{MMBtu})$, or less is available for export at a higher price, revenues will decrease as will associated royalties and rents. For Bolivia to maintain its revenues and international balance of payments, it will essentially need to open to the market and move away from the strong nationalist approach under which it currently operates. That this may transpire under Bolivia's populist and resource nationalist Morales administration will be of keen interest.

\section{Major Conclusions of Chapter Four}

There are certain hard realities for each country in the case study. Every country is limited in one form or another when making decisions; however, certain countries are more constrained than others.

Bolivia needs to sell its natural resources to generate revenues. The bulk of its revenue derives from natural gas sales to Brazil, its major customer. During the period before Bolivia's dictatorship (middle-1960s), natural gas trade was negligible and only harnessed as a commodity later, and mostly with Argentina. Post-dictatorship Bolivia (1985 - present) witnessed an increase in natural gas as a significant percentage of GDP, but still mainly relied on Argentina as a customer. This all changed as the Bolivia-Brazil

${ }^{157}$ Interview which took place between SEP and NOV 2017. 
pipeline came online in 1999, which resulted in a substantial increase in the sale of natural gas as Brazil replaced Argentina as customer of choice. However, it is presently possible that because of natural gas discoveries off Brazil's coast, the Bolivia-Brazil relationship may change.

Bolivia benefitted from high prices. Also, Brazil functioned as dedicated customer at a time when pre-Morales legislation paved the way for a vertiginous rise in Bolivian natural gas revenues. The ebb of natural gas prices from earlier years' rise likely looms large in Bolivian planners' minds. The volatility of rents associated with Bolivian natural gas requires fiscal discipline if Bolivia seeks to avoid the downside of a commodity boom.

Essentially, Bolivia needs to reform its system if it is to attract FDI, particularly that of IOCs, to develop its natural gas resources. The current situation in Bolivia inhibits IOC exploration because it is cost prohibitive, despite being good for revenue and rent generation at this moment in time. Bolivia may face a hard lesson that it must again open its economy to the international market to attract needed investment. Under Bolivian President Evo Morales (2005-Present), the trend of increased natural gas sales continued, and the amount of revenue generated from these sales also increased because of the combination of the global rise in price and the Bolivia-Brazil pipeline reaching capacity.

In neighboring Brazil, choices are also necessary. However, Brazil's choices are likely to not be as difficult as in Bolivia; the former's economy is much more developed than the latter's. Brazil needs natural gas from Bolivia despite much of its energy being produced hydroelectrically. Natural gas will remain a necessity in times of drought, as 
well as if Brazil desires to further develop its northeast and interior, which are vital to improve the quality of life, opportunities, and GDP. Despite Brazil's major hydrocarbon discoveries off its southern coast, the recent economic recession compelled Petrobras to sell exploration rights to some of its fields. Selling off assets may affect Brazilian natural gas production in the years ahead.

How this dissertation answers the original research questions is found in Chapter Five, Analysis and Assessment. What is already certain is that Bolivia and Brazil are no longer able to hide the results of historic and egregiously poor policies.

\section{Works Cited:}

ABS Consulting Group. "Diagnostico de la Generacion en America Latina y el Caribe: Bolivia." Latin American Energy Organization, Aug. 2013, pp. 2-141.

Agencia Nacional do Petroleo, Gas natural e Biocombusteveis (ANP). "Boletin Annual de Precos 2015: Precos do Petroleo, Gas Natural e Combusteveis nos Mercados Nacional e Internacional.” Rio de Janeiro, 2015.

Arezki, Rabah et al. "On the Comparative Advantage of U.S. Manufacturing: Evidence from the Shale Gas Revolution." Centre for Economic Performance, CEP Discussion Paper, no. 1454, Nov. 2016.

Biasetto, Bruno Henz. The Poisoned Chalice: Oil and Macroeconomics in Brazil (19672003). Dissertation, Graduate School of Arts and Sciences, Georgetown University, 2016.

Condor, Jose. "El Desarrollo de Los Recursos de Gas Natural en America Latina y el Caribe Podria Convertirse en una Fuente de Energia Competetiva?" Latin American Energy Organization, OLADE-CIDA. Oct. 2014.

Dumaine, Brian. "U.S. Manufacturing Costs are Almost as Low as China's, and that's a Very Big Deal." Fortune Magazine. http://fortune.com/2015/06/26/frackingmanufacturing-costs/, 26 June 2015, accessed 20 January 2018.

Dussan, Manuel. "Bolivia: Enormous Reserves, Political Restrictions." Gas Market Integration in the Southern Cone, edited by Paulina Beato and Juan Benavides, InterAmerican Development Bank, 2004, pp. 37-70. 
Fagundes de Almeira, Edmar Luiz. "Brazil: A Key Push for Integration.” Gas Market Integration in the Southern Cone, edited by Paulina Beato and Juan Benavides, InterAmerican Development Bank, 2004, pp. 71-120.

Fagundes de Almeira, Edmar Luiz. "Reestructuracion del Sector de Gas Natural en Brasil: Perspectivas para Bolivia." Grupo de Economia da Energia, Apr. 2017, Santa Cruz de la Sierra, Bolivia.

Fagundes de Almeira, Edmar Luiz. "Puede ser Ventajoso para Bolivia Tener Varios Compradores de Gas en Brasil.” Petroleo y Gas, May/Jun 2017.

Garron, Mauricio B and Pablo Cisneros. "Metodologias para La Determinacion de Precios de Gas en la Region.” Latin American Energy Organization, Articulos Tecnicos, Jan. 2007, pp. 1-20.

Glachant, Jean-Michel and Michelle Hallack. "Take-or-Pay Contract Robustness: A Three Step Story Told by the Brazil-Bolivia Gas Case.” Energy Policy, vol. 37, no. 2, Feb 2009, pp. 651-657.

Gomes, Ieda. "Brazil: Country of the Future, or Has Time Come for Natural Gas?" Oxford Institute for Energy Studies. University of Oxford. June 2014.

Silva, Milko Luis Gonzalez et al. "El Factor Energetico y Las Perspectivas de Integracion en America del Sur." Instituto Latinoamericano de Investigaciones Sociales, Apr. 2008, Caracas.

Honore, Anouk. "South America Gas Markets and the Role of LNG." Oxford Institute for Energy Studies, OIES Paper, NG 114, Oct. 2016, University of Oxford.

International Energy Agency. "Key World Energy Statistics.” 2016.

International Energy Agency. "World Energy Outlook 2017. 2017.

Kolb, Robert W. "The Natural Gas Revolution: At the Pivot of the World's Energy Future." Pearson Publishing. 2013.

Medinacelli, Mauricio Monrroy. "Impuesto Directo a los Hidrocarburos: Origen, Destino y Usos.” International Institute for Democracy and Electoral Assistance. December 2007.

Medinacelli, Mauricio. “El 'Incentivo' para Incrementar la Produccion de Petroleo en Bolivia." Mauricio Medinacelli Monrroy, Blog .063, 17 Nov. 2015, http://www.mmedinaceli.com/index.php?option=com_content\&view=article\&id=85:blog 063\&catid=3: contenblog \&Itemid=6\&lang=es\#t=13. Accessed 17 January 2017.

Medinacelli, Mauricio. "Exportacion Gas Natural Bolivia-Brasil ¿Menores Volumenes?” 8 Dec. 2017, http://www.youtube.com/watch?v=gjPPACPxG0s. Accessed 4 February 2018.

Medinacelli, Mauricio. "Relacion entre Precios del Gas Natural y Precio del Petroleo." 6 Jan. 2018, 
http://www.youtube.com/watch?feature=youtu.be \&v=zbhf3ktWeZA\&app=desktop, Accessed 4 February 2018.

Prates, Claudia Pimentel T et al. "Evolucao da Oferta e da Demanda de Gas Natural no Brasil." O Banco Nacional do Desenvolvimento, Setorial, Rio de Janeiro, no. 24, Sep. 2006, pp. 35-68.

Reuters. "Petrobras, YPFB Chaco to Invest $\$ 1.2$ billion in Bolivia Gas Exploration." https://www.reuters.com/article/us-petrobras-bolivia/petrobras-ypfb-chaco-to-invest-1-2billion-in-bolivia-gas-exploration-idUSKBN13226L, 7 Nov. 2016. Accessed 28 Jan. 2018.

Silva, Andre Luiz Reis. "Do Otimismo Liberal a Globalizacao Assimetrica: A Politica Externa do Governo Fernando Henrique Cardoso (1995-2002)." Dissertation, Universidade Federal do Rio Grande do Sul, Curitiba, 2009.

Victor, David G, et al. "Oil and Governance: State Owned Enterprises and the World Energy Supply." Cambridge University Press. Cambridge. 2012.

The World Bank. Data.

https://data.worldbank.org/indicator/EG.ELC.FOSL.ZS?end=2014\&locations=BR\&start $=1971 \&$ view $=$ chart, Accessed 28 Jan. 2018.

Yacimientos Petroliferos Fiscales Bolivianos. "Boletin Estadistico: 2013.” 2014, La Paz, Bolivia.

Yacimientos Petroliferos Fiscales Bolivianos. "Boletin Estadistico: 2015.” 2016, La Paz, Bolivia. 


\section{CHAPTER FIVE: ANALYSIS AND ASSESSMENT}

\section{General Statement:}

This dissertation fits into the overall context of twentieth century Latin America economics and politics. The findings nest within more expansive questions on international political economy and export-driven models of development. Why do populist regimes, historically operating under an economic nationalist cum protectionist paradigm, simultaneously pursue policies of economic integration? What is the relationship between resource nationalists and open markets, especially in the hydrocarbons sector? What is the relationship between populists, who are typically resource nationalists, and their decision to choose policies of energy integration?

The most common responses to the above are that resource nationalists pursue protectionist policies in the hydrocarbon sector. This dissertation demonstrates that once in power, resource nationalists do not always pursue protectionist policies in the hydrocarbon sector, but instead rely on market forces. Another common response is that populists pursue policies of resource nationalism in the hydrocarbon sector. This dissertation also demonstrates that populists do not always pursue policies of resource nationalism in the hydrocarbon sector, but instead choose policies of integration. Policies of integration are compelled by market forces, and at times ironically provide the foundation for resource nationalism to later flourish. In Bolivia and Brazil, populists are able to maintain or deepen free market policies during commodity upswings. This is the true paradox of populism. 
This conclusion begins with a synopsis of international economic events as generally experienced in Latin America, a brief section on the evolution of populism in twentieth century Latin America, then focuses on the Bolivia and Brazil experiences. The final section discusses the applicability of this dissertation and identifies avenues for future research.

\section{The Latin American Experience in the Twentieth Century:}

The worldwide economic depression of the 1930s greatly impacted Latin American export-driven economies. The worldwide drop in commodity prices weakened the economies of Bolivia and Brazil respectively, and both countries learned hard-fought economic lessons from the experience. From the depression through the 1960s, both countries attempted to implement ISI programs to help reduce foreign dependency as well as lessen their strict reliance on commodity exports. From the mid-1960s through the mid-1980s, Bolivia and Brazil underwent great domestic transformations through military dictatorships. During this period, the oil and interest rate shocks of the 1970 s and 1980s strongly limited the countries' development goals. When the military as an institution abandoned direct political involvement in the mid-1980s, the private sector was free to implement neoliberal economic reforms.

Populists of the right who eschewed the state capitalist model emerged during this time. The subsequent leftward shift across Latin America in the early 2000s is often viewed as a direct result of failed market-based reforms that left large swaths of citizens bereft of the same economic gains realized by domestic and international elites. 
However, these same market-based reforms ironically provided the foundation for resource nationalists to emerge. Prior to 2010, the region returned to a commodity-driven export model buoyed by higher prices in oil, natural gas, and mining. Bolivia and Brazil experienced resultant booms in export revenue. However, increased wealth and government largesse masked persistent harmful rent-seeking behavior and weak government institutions.

In Bolivia and Brazil, the twentieth century witnessed shifts from authoritarian to democratic regimes, and from populism, to anti-populism, to neo-populism. In neither country did these regimes last long, although in Brazil some transitions were smoother than in Bolivia. A cyclical, almost circular, experience remains in both countries. Like most countries in Latin America today, Bolivia and Brazil remain challenged in developing their economies beyond a largely export-driven model. Although some countries are diversifying their economies with more success than others, all countries in the region remain linked to the international system of trade and the fluctuation in world commodity prices.

Bolivia, Brazil, Natural Gas Markets, and Nationalism; a Summary:

Since Bolivia developed its natural gas deposits in the 1970s, revenues from subsequent sales became an increasingly important contributor to the economy. No president in Bolivia whether overtly nationalist, populist, or neoliberal ceased exporting this commodity. During the dictatorship in Bolivia, natural gas sales continued, mostly to Argentina. After the dictatorship ended, the neoliberal experiment began in Bolivia, as 
well as in Brazil. During this period, Bolivia briefly sold gas to Chile, which ended in Bolivian political disaster. The subsequent instability in Bolivia ushered Evo Morales into power as a would-be anti-neoliberal president. Meanwhile in Brazil, the leftist Cardoso pushed through neoliberal economic reforms, which presidents Lula, Rousseff, and Temer maintained.

In Bolivia, Morales maintained the commodity-driven export policies of his predecessors and thus the pipeline deal with Brazil. Morales, however, altered the percentage of royalties distributed to the central and local governments, as well as other centers of patronage. The Brazilians from Cardoso onward were also keen to maintain the relationship as it was mutually beneficial, and did so irrespective of political alignment. A December 2017 meeting between Morales and Temer on the topic of the natural gas relationship supports this argument.

Data demonstrates the relationship between resource nationalists and open markets is that in the case of the Bolivia-Brazil pipeline, much of the rhetoric of the Morales administration does not match its actions. Morales likely considers the nature of IOCs and their relationship with Bolivia exploitative. It is also likely the Bolivian government, and Morales himself, holds strong antipathy towards the private sector. Prior to the Morales administration, the pipeline was in place, the price of natural gas was on the rise, and the 2005 Hydrocarbon Law was already in effect. Essentially, despite the very public seizing of foreign assets, the system in place prior to the Morales presidency remained mostly intact, barring some renegotiation of terms. On the Brazil side of the border, the gas continued to flow and the Brazilians continued to buy. Increased trade and associated revenue filled coffers and allowed patronage to expand and flow. Natural 
gas powered industry, and access to energy reached hitherto unintegrated interiors of both countries.

Data also demonstrates the leftist Lula and his hand-picked successor Rousseff maintained some of the neoliberal policies in place during the Cardoso administration. Center-right president Temer is moving beyond former administrations and deepening these policies, just as Morales deepened the policies of his predecessors. Also similar in both countries was some redistribution of wealth, bringing millions out of poverty. Regional energy integration remains as important as it is elusive, however.

For Bolivia and Brazil, benefits exist on both sides of the border, especially during peak initial construction of the pipeline. Pipeline construction afforded employment to many. Primary employment during the creation of the pipeline, as well as secondary forms of employment (ancillary services and support), developed. Upon completion of the pipeline, maintenance workers and technicians remained behind to ensure pipeline functionality. Since the completion of the pipeline, Corumbá, Brazil, where the pipeline between the two countries passes, has benefitted from formal and informal economic activity. Such activity ranges from food vendors to taxi drivers shuttling people across the Bolivia-Brazil border. Shopping malls, entertainment venues, and other forms of commerce also are present in the city.

Ultimately, while there are advantages to being a supplier of a desired commodity, the bilateral nature of trade between Bolivia and Brazil has its disadvantages. If Bolivia remains dependent on the large-scale export of natural gas to a single destination such as Brazil, its influence over the price of the commodity will remain limited. As natural gas is vital to the health of the Bolivian economy, failure to meet 
export commitments would threaten its development, and possibly its fiscal survival. It is ideal for Bolivia to develop new markets or to stimulate new investment. With large scale exports of natural gas, Bolivia may continue to benefit from economies of scale.

\section{Populism in Latin America; an Evolution:}

Old populism existed between the people and the oligarchy. The results were an uneasy association (hardly a true alliance) among popular and middle-class sectors of society. During this period, the state held its place as protector of the people and the marginalized. During this time, powerful links between a charismatic leader and the masses undermined representative democracy and government institutions. This old populism waned because of a confluence of factors. First, in the post-Second World War period a democratic wave swept across Latin America. Second, the ISI development model (core to old populism), was exhausted. Third, during the Cold War period, the shift from populism to revolution in Latin America created a new paradigm.

In the post-Cold War environment, a new populism emerged in several stages. In the first stage, there was a successful macroeconomic period whereby governments attempted counter-inflationary policies. Second, elected leaders began to govern by decree and held a direct appeal to the masses. Third, democracy became more personalistic regardless of whether emerging from the left or the right. Last, there have been both populist and non-populist responses to economic reform. In the 2000 s there emerged an ethnic-based component to populism; however, it is too soon to determine if this will last. 
Both old and new populism demonstrate inherent tensions and contradictions between representative democracy and associated institutions. The problem though is not populism per se, but underlying driving factors such as poverty, inequality, and the degeneration or decomposition of traditional political institutions. Strong economic development is vital to democratic consolidation, while poverty and inequality clearly undermine the trappings of democracy, and often result in an unsustainable, if not dangerous, populism.

\section{Competing Development Logics/Models: Bolivia and Brazil:}

The most important factor in development models and a country's subsequent political stability remains economic. Common to the region, and within Bolivia and Brazil respectively, is the continual tension between political and economic logics that drive development policy. Bolivia and Brazil mostly fit within the larger question of democracy as theorized by Robert Dahl (1971), and in the cases of Bolivia and Brazil electoral democracy exists. Despite both countries meeting many of Dahl's criteria for polyarchy, Bolivia and Brazil are not consolidated or institutionalized, although democracy endures. There is concern, however, for authoritarian regression in both countries.

Democracy remains in Bolivia and Brazil; however, each is uniquely rooted in recent historical experience. Bolivian democracy is less institutionalized and less developed than in Brazil. In fact, Bolivian democracy may be regressing as power increasingly concentrates in the executive. Moreover, Bolivian political leadership 
continues to bypass its own democratic institutions. Meanwhile in Brazil, there is some democratic stability based on either the willingness or need of political parties to engage with one another to govern; however, open talk of a military coup in Brazil during 2017 is unnerving. Moreover, in late-2017 and early-2018 Brazil is barely pulling itself out of a deep recession; political tension may worsen if economic growth remains anemic.

In the simplest terms, tension exists between state-capitalism and private sector development models. There is an additional conflict that centers on how to use capitalist surplus to pay for development, and particularly who is to pay. The decision of how, and who is, to pay for development vacillates between those in favor of accumulation and those pursuing a distributive logic. Those who favor accumulation are the entrepreneurs and middle-class; those in favor of distribution are organized labor and the popular sectors.

Government expenditures created the middle-class in Latin America. Rentism (in the case of Bolivia and Brazil) generates the expectation of wealth among the lower and middle classes. This expectation of wealth is particularly salient if resource nationalism is a theme government leaders incorporate into their discourse or overarching ideology. The state largely redistributes rents from royalties, such as natural gas. Capturing the presidency offers the winners access to a vast patrimonial machine, which disperses wealth to colleagues, supporters, and political allies.

Rent-based patronage systems in Bolivia and Brazil created the middle class. Key figures from within political parties, particularly in Bolivia after the discovery of natural gas in the east, harnessed this patronage machine to reward the middle class who were dependent upon the state for their positions. The existence and development of the 
middle class is directly based on its ability to access the state as a source of jobs. However, to achieve long-term stability, there is a need to incorporate the popular sectors of a country into the economy and government. Within this overarching competing logic fits the model of production, which across Latin America shifted among populism of the left and right, state-led capitalism, and open market capitalism. Populism drives the authoritarian/democratic regime cycle, and wrought state capitalism, but the dilemma of accumulation versus distribution remains.

\section{Bolivia:}

That nationalization took place during a time of increasing commodity prices is not unexpected. Nationalized firms during times of peak international commodities prices historically increased royalties and rents for the country. Royalties and rents contributed to and fueled already established patronage systems. Despite nationalizations in Bolivia, foreign interests have continued to invest under Morales. Data demonstrates that the amount of FDI increased during the Morales administration, notably after 2005. Also, exports increased greatly after Morales took office, almost tripling in some years since the Sanchez de Lozada era. Based on this dissertation, it is fair to conclude that had not Evo Morales inherited a country during an upswing in the commodity cycle, his patrimonial influence would have not garnered him the political longevity he is currently experiencing.

Bolivian presidents from 1989 to 2005 maintained the open market approach initially emplaced under Paz Estenssoro in 1985. Bolivian presidents continued to implement policies that ensured the Bolivian economy would continually integrate itself 
into the world economy. The final two presidencies prior to the Morales era show that Bolivian administrations continued with neoliberal economic policies, but were caught in a downward commodity cycle. In Bolivia, Morales conspired to overthrow Sanchez de Lozada because of the potential of exporting natural gas to Chile. In the Bolivia case, there is no greater example of resource nationalism than this.

Under Morales, the Movement for Socialism (MAS) party emerged as a serious political force and remains in power today. Of course, prior to the 2006 nationalization of Bolivia's hydrocarbon sector, shifts in production and price were already in the ascendant. Morales benefitted from a relationship with Brazil that was over two decades old, which was transversal across populists of the left and right, as well as neoliberal administrations. The major shifts in natural gas production, post-2005 increase in royalties for Bolivia, and the increased price in natural gas in global and sub-regional markets ensured Morales' economic success once at the helm. President Morales took advantage of increased natural gas prices concomitant with laws enacted prior to his election. Claiming credit for the natural gas resource boom in Bolivia, Morales has simultaneously criticized the behavior of Bolivia's neoliberal governments.

Clearly, Bolivia must sell commodities to generate revenue. Presently, the lion's share of Bolivia's revenue derives from natural gas sales to Brazil. Brazil remains a dedicated customer. Bolivia as an exporter historically benefits from high commodity prices, whether silver, tin, or natural gas. However, the historical lack of investment in productive sectors of the economy limits Bolivia's potential as it is unable to achieve escape velocity through diversification as have other countries in the region. Moreover, the volatility of rents requires fiscal discipline if Bolivia seeks to avoid the inevitable 
downside of any commodity boom. It is possible that because of natural gas discoveries off Brazil's coast, the Bolivia-Brazil relationship may change.

Historically, there is a relationship between protests in Bolivia and anticipated rents. Prices in monopolies are established through a process in which an authority calculates price based on a cost structure inclusive of pre-established rents. Once a commodity boom becomes the inevitable bust, this structure is thrown out of balance. The high volatility inherent in Bolivian commodity revenues during the twentieth century, whether tin or natural gas, as well as associated rents have historically plagued the country, challenged political stability, and undermined social cohesion. Bolivian gas revenues and rents via sale to Brazil were a flash in the pan, finite, and unsustainable. Without calculated investment in the productive sectors of the economy during times of plenty Bolivia will be unable to weather the looming commodity bust without facing an institutional crisis.

Bolivia needs to reform its system if it is to attract FDI as well as needed IOC experience and technology to develop its natural gas resources. Presently, Bolivia inhibits IOC exploration because it is cost prohibitive, despite being beneficial for revenues and rents. If the Bolivian economy is not diversified through investment and international engagement, the country will likely again face a painful lesson. Moreover, it is possible that because Bolivia did not further develop its natural gas reserves, it may miss an opportunity to gain revenue should there be an uptick in oil price. 
Brazil:

As Brazil moved from a nationalist-industrialist economy to one of exports, it experienced an impressive economic reversal. Post-1964, the balance of foreign to domestic capital in Brazil increased. This increase led to an acceleration after 1985. By the time Cardoso left office in 2002, inflation was largely under control. Concomitantly, the election of initially leftist politicians like Cardoso affected the national economy when privatization accompanied some denationalization.

Cardoso laid the neoliberal groundwork for a massive inflow of foreign capital investment, which grew under Lula. President Rousseff continued with these policies; however, a lack of confidence in markets, a recession, and credit downgrade stalled or reversed many social programs. These events fed into general negative atmosphere alongside corruption scandals and mass protests. Brazil's commodity-fueled growth during high demand provided unrealistic and unsustainable expectations. Again, based on this dissertation, it is fair to conclude that had not Lula inherited a country during an upswing in the commodity cycle, his patrimonial influence and access to largesse would have not garnered him the political longevity he experienced.

International and domestic forces also constrain Brazil's actions. The dizzying increase in oil prices allowed lawmakers to push through restrictions on Brazil's pre-salt deposits to capture more rents for the country. Offshore crude discoveries during the Lula administration were touted as a gift that would directly benefit the people. Several years later, Petrobras' revenue dropped because of reduced oil prices, and now the parastatal is one of the most indebted oil companies in the world. The company is unable to increase production, has begun selling its assets to become leaner, is attempting to 
reduce debt, and is compelled to seek outside investment. Brazil also reversed legal restrictions on IOC operations regarding its pre-salt deposits. Ideally, this decision will reduce the burden on Petrobras, increase foreign and domestic investment, and increase oil production moving forward.

The combination of the PT's policies and corruption sent Brazil into a deep and extended depression; however, the blame cannot solely be laid on the PT, as corruption in Brazil is legendary and has transcended administrations of the left, center, and right. President Michel Temer enacted an aggressive reform agenda that attempted to lift Brazil from depression and reduce state involvement in the economy. Since 2016, Temer's center-right administration shifted away from the populist, statist, and protectionist trajectory of Lula's PT (2003-2016). Despite four consecutive quarters of tepid growth in 2017, Brazil's economic position remains tenuous, and arguably may slip back into recession. Of keen interest to energy analysts, economists, and political scientists alike is that many of Brazil's actions parallel those of Mexico's during its historic 2013 energy reform. ${ }^{158}$ The liberalization of both countries' parastatals reversed decades of nationalist energy policy. As the price of oil fluctuates, policy changes follow. Amid a current economic, political, and corruption crisis, historical experience suggests Brazil will lean towards a centrist, or center-right, leader who will push ahead with current reforms.

Brazilian industry demands Bolivian natural gas. Natural gas trade with Bolivia endures and has transcended populist presidencies of the left and the right, as well as

\footnotetext{
${ }^{158}$ Although preliminary data demonstrates a drop in oil exports from 2013 to the present, and a brief spike in FDI in 2013, it is too soon to determine the effects of Mexico's reform (MIT, The Observatory of Economic Complexity: http://atlas.media.mit.edu/; The Global Economy: http://theglobaleconomy.com/; accessed 23 June 2018).
} 
neoliberal administrations. The pipeline relationship with Bolivia will endure, but with a likely decrease in gas purchases. Brazil will continue to import Bolivian gas, while also focusing on developing its hydrocarbon sector.

\section{Applicability, Final Observations, and Beyond}

\section{Applicability:}

There was a need to look at both Bolivia and Brazil because of the nature of natural gas as a commodity - essentially, a seller needs a buyer. Market forces are an inescapable reality that compel or constrain countries in their ability to decide the direction of their country. Some countries can weather pressures better than others, however. Whether political leaders are economic nationalists, resource nationalists, populists of the left or right, or neoliberal in their outlook, market forces are political determinants, and integration into the world economy is inevitable. It is possible that if Brazil develops its offshore resources, some of the conclusions from the Bolivia experience may apply.

The intent of the dissertation case study was to explain the relationship between resource nationalism and energy integration. This was a success. However, it is unlikely the conclusions of this study are applicable to countries outside of Latin America, or possibly even outside the realm of natural gas exporters. Despite these limitations, this dissertation identified similar patterns in Bolivia and Brazil relative to export dependency and links to the boom/bust cycle of international markets. Without continued diversification away from an export-centric model, and simultaneous pursuit of regional 
economic integration, both Bolivia and Brazil may remain in the situation that has historically plagued their development. Moreover, both countries are on different political trajectories.

Despite their likely divergent paths, a bilateral agreement on natural gas between Bolivia and Brazil can endure. It is unclear if the integration of natural gas markets between Bolivia and Brazil will extend or deepen to other energy sectors such as electricity, or to countries in the Southern Cone. Almost certain is that complete energy integration, particularly that of natural gas, is presently far too complex of an issue to extend across the entirety of South America, regardless of the political leadership in each country.

Weaknesses in this study exist, but are limited. To better examine rents, an ideal metric would be to determine government personnel expenditures as a percentage of GDP for both Bolivia and Brazil. Looking at the relationship between this metric and political leadership over time could offer interesting results relative to how rents are distributed and under which regime. However, the data available to make such an observation is spotty and unreliable.

This study is limited in its direct applicability outside of Latin America; however, some lessons are clear. First, investment is needed in the productive sectors of society if countries are to escape an export-dependent development model. Second, if domestic capital is insufficient to fuel development, international capital is needed; however, the latter subjects a country to the whims of a commodity boom/bust cycle. Third, rents weaken democratic governance as pursuit of state power degenerates into conflict between "haves" and "have nots" within a country. Such factionalization erodes 
institutions and makes political competition equivalent to the pursuit of the perks of power alone, not of governance.

Equally challenging to this study's applicability outside of Latin America and the regional natural gas sector, is the market price of natural gas. The pricing of natural gas is deceiving and does not follow a reliable mechanism. Historically, the price of natural gas was a function of the price of oil. However, this pricing method does not follow a predictable logic and is subject to regional and sub-regional calculations and possible abuse. The distortion between the price of oil and natural gas is considerable. ${ }^{159}$ Moreover, there is an inverse relationship between consumption and price levels based on the sector using natural gas. ${ }^{160}$ If too costly, the consumer will not purchase natural gas.

For a country that sells natural gas, this could be a serious concern.

\section{Final Observations:}

In Bolivia, Morales' MAS has a solid hold on the Senate and Chamber of Deputies. In Brazil there is a shift towards a centrist government with a coalition of the PSDB, MDB (historic PMDB), and elements of the Progressive Party in both the Federal Senate and Chamber of Deputies. In Bolivia, the opposition is too weak to confront

\footnotetext{
${ }^{159}$ For example, one barrel of oil is $\sim 5.7$ million Btu. One thousand cubic feet of natural gas is $\sim 1$ million Btu (U.S. Energy Information Administration website calculator). Using Btu as a metric, gas should be valued at roughly one sixth the price of oil. Hence, if oil costs $\sim \$ 60 /$ barrel, natural gas should cost $\sim \$ 10$; however, at the time of writing it costs $\sim \$ 3$. This discrepancy demonstrates there are additional variables involved in natural gas pricing, which presents a challenge for deeper evaluation or analysis.

${ }^{160}$ Thermoelectric pays the least, but consumes the most. The industrial sector consumes less than thermoelectric, yet pays more. The commercial sector consumes less than the industrial sector, yet also pays more. Vehicles consume less, as does the residential sector, yet both sectors pay more for natural gas.
} 
MAS. In Brazil there is no unified coalition in congress to support all reforms concerning rule of law and economic stewardship. Bolivia's MAS is increasing its power within the executive, but also within some form of democratic framework. Brazil does not seem to be experiencing executive branch power concentration, but instead appears to be governing through some form of coalition.

Economic policies in either country, whether based on free/open market economics or state-capitalism, have not ended practices of clientelism, patronage, or rentism. Democracy has also not ended such practices. In both countries, external market forces may compel governments and elites to enact austerity programs. Such austerity programs are often made to the detriment of the popular sectors. Economics in Bolivia and Brazil remain central to political stability.

Separate from the economic and political arguments within Bolivia and Brazil, natural gas in the Southern Cone still provides the best opportunity for regional energy integration in Latin America. Outside of the region, the nature of the natural gas market is changing in several aspects, which may affect Latin American markets. First, the emergence of LNG as a nascent internationally integrated market differs from the regional/sub-regional natural gas markets currently in operation. Second, the price structure of natural gas, historically linked to oil, will potentially face delinkage. Third, natural gas is a cleaner burning fuel than oil, can meet the needs of our energy-intensive society, and can presently do so with much more ease than renewables. In fact, natural gas may be able to support the development of erratic and variable renewables such as solar and wind until which time a market-based renewable sector can emerge without costly government subsidies. 
There is an expectation that Brazil's offshore oil deposits will provide wealth to the population. However, because of political instability Petrobras is presently limited in its ability to immediately develop these fields. If the fields are not developed, whether by Petrobras, an IOC, or through a joint venture, no rents or royalties can result. The lack of rents will weaken the ability of the government to redistribute its wealth and leverage political capital towards the country's economic development. In both Bolivia and Brazil, without investment in the productive sectors of the economy, they will not be able to diversify away from this development model. Remaining wedded to this model leaves Bolivia and Brazil subject to the external whims of the market, and simultaneously squeezed by the internal demands of the population.

Resource nationalism is a powerful barrier to energy integration. Proximity between Bolivia and Brazil drives their integration relationship. Bolivia is a major gas producer lacking a developed domestic market, whereas Brazil is a major gas consumer with a strong industry. Despite this relationship making near perfect market sense, political foundations and agreements on energy integration between Bolivia and Brazil were necessities prior to breaking any ground. Though, since its inception, the integration relationship between the countries transcended nationalist, populist, and neoliberal governments. Geopolitical realities indicative of the natural gas market drove energy integration between Bolivia and Brazil. The market ensures this relationship continues, and now functions almost independently of politics. But, nothing is guaranteed, and market shifts are afoot.

Petrobras is presently the main buyer of natural gas in Bolivia. The current contract relationship between Bolivia and Brazil expires in 2019. Petrobras plans to 
reduce its purchases of natural gas by half. If Petrobras reduces its purchase of Bolivian gas, much of the largesse available to Morales through royalties, taxes, and rents will diminish. For Bolivia, the golden age of high prices and limited competition in the natural gas market is over. Aside from lost rents and the associated patronage that mostly benefit the middle class and elites, the entirety of the Bolivian economy will likely suffer. This pain will come as a direct result of Bolivia's historical lack of economic diversity. Despite decades of warnings, Bolivia remains dependent upon commodity exports. Natural gas exports are the latest manifestation of such dependence.

Should Petrobras reduce its gas purchases, Bolivia may be compelled to revisit its relationship with Argentina, become open to selling gas to Chile, enter the LNG market, combine these options, or possibly something else not yet conceived. Engaging with Argentina is possible as there is a history of natural gas trade between countries. Contracts with Argentina took place during two of Bolivia's three natural gas booms (1970-1999; 2011-2015). As of 2017, Argentina remains the regional leader in natural gas consumption, and Bolivia should not ignore this market. Selling gas to Chile will require a radical change in what has been nearly uninterrupted hostile Bolivian nationalist rhetoric since the late nineteenth century. Entering the LNG market will be determined by the amount of natural gas Bolivia can produce, and if that amount is sufficient for expansion into that market. Regardless of what Bolivia decides, the need to be flexible in the natural gas market is the starting point. 


\section{Future Research Opportunities:}

Upon completion of this dissertation, new questions have emerged. Future studies on the natural gas relationship between Bolivia and Brazil should center on how this relationship will change if Brazil develops its hydrocarbon reserves, how it develops these reserves, and under what type of administration this transpires (populist of left/right, statist, or free-market).

Additional research should focus on how Bolivia's MAS endures amid what seems to be an inevitable decline in natural gas revenue, and what sectors of civil society will emerge in its wake? An additional question is if Bolivia will again be thrust into a conflict that requires military or outside intervention.

Additionally, how to incorporate varied sectors of civil society into a party or institution needs to be addressed. If traditional institutions or political parties erode, will another charismatic leader emerge to reach the people outside of these institutions? Will "the street" then become legitimate? Bolivia and Brazil have seen much protest in recent years, and these protests are closely related to patronage and the expectation of rents. If stability is dependent upon rents, how will democracy be consolidated when powerful market forces greatly burden a population?

Finally, much information gathered during this dissertation, whether through reviewing academic and trade journal literature, analyzing statistical tables, or interviewing experts, did not find its way into the final draft. Many issues of import fell outside the scope of this study, and are ideal places for future studies to begin. These questions exist at the global and regional levels. 
There are a few areas for future study that are global in scope. For example, determining the price of natural gas is something that varies across geographies and is further subdivided into regional markets. A lack of a clear, precise, and transparent mechanism to determine the price of natural gas confounds analysis. Additionally, the emergence of an incipient international market for LNG is only briefly touched upon in this dissertation and demands future attention. Essentially, can LNG emerge as an internationally integrated market? If so, will there be attempts to create a natural gas cartel in the now faded image of OPEC? Also related to LNG as a global commodity export is how much natural gas is required to benefit from this market and do Bolivia and Brazil have sufficient quantities towards realizing this end?

Regional questions also remain unanswered. First, how do governments calculate rents? A subset of the rent calculation question is how do IOCs determine whether to remain in a country during nationalizations, and how are they able to function despite the associated reduction in revenue? Next, what are the political or cultural calculations governments face when attempting to resolve pressing economic questions? Third, studies examining why regional integration attempts, such as Petrolatín in Latin America, failed would add value through identifying and explaining associated integration challenges. Historic explanations blame the debt and interest rate crises; however, after several decades a revived line of research could inquire if such a venture is now conceivable.

These questions may have already been answered outside of academia, but the information possibly remains in the archives of IOCs, NOCs, or is closely-guarded within energy consulting firms. 
VITA

\section{BRIAN EDWARD HOLLINGSWORTH}

Born, Miami, Florida

B.S. English Education

Florida State University

Tallahassee, Florida

1996-2008

Educator: Miami, FL; Los Angeles, CA; Monterrey, Mexico

2003

M.A. International Relations

Florida International University

Miami, Florida

2008-2018

Consultant: Baghdad, Iraq; Washington D.C.; Tegucigalpa, Honduras; Lima, Peru; Bogota, Colombia; Kingston, Jamaica; Miami, FL

2014-2018

Doctoral Candidate

Florida International University

Miami, Florida 